UNIVERSITÉ PARIS 8 - VINCENNES-SAINT-DENIS

ÉCOLE DOCTORALE PRATIQUES ET THÉORIE DU SENS

UNIVERSIDADE DE SÃO PAULO - USP

DEPARTAMENTO DE TEORIA LITERÁRIA E LITERATURA COMPARADA

\title{
REPRESENTAÇÃO E PRÁTICA DA CRIAÇÃO LITERÁRIA NA OBRA DE JOÃO CABRAL DE MELO NETO. ANÁLISE TEXTUAL E PROTOTEXTUAL
}

FRANCISCO JOSÉ GONÇALVES LIMA ROCHA

TESE DE DOUTORAMENTO (REGIME DE CO-TUTELA)

SOB A ORIENTAÇÃO DE

MARIA HELENA ARAÚJO CARREIRA E SANDRA MARGARIDA NITRINI

DEFENDIDA EM 5 DE JULHO DE 2011

MEMBROS DO JÚRI :

MARIA HELENA ARAÚJO CARREIRA

ProfESSEUR DES UNIVERSITÉS, UNIVERSITÉ PARIS 8 - VINCENNES SAINT - DENIS

SANDRA MARGARIDA NITRINI

ProfESSORA TITUlar, UNIVERSIDAdE DE SÃo PAULO - USP

MARIA GRACIETE BESSE

Professeur des Universites, Universite PARIS IV - SORBONNE

JACQUELINE PENJON

ProfesseUr DEs UnIVERsites, UNIVERSITE PARIS III - SORBONNE NOUVELLE

ANDREA SAAD HOSNNE

Professora doUtora, UniversidAdE DE SÃo PAUlo - USP 


\section{Agradecimentos}

À professora Maria Helena Araújo Carreira, por ter me acompanhado desde o mestrado, $e$ à professora Sandra Margarida Nitrini, por ter aceitado me co-orientar no doutorado.

À Anna, ao Thomas e à Stéphanie, amigos em Paris.

Ao Rafael, pela generosa recepção no Rio de Janeiro.

Ao Renato Callado, pela justa tradução para o inglês do resumo.

Ao André, pelas conversas ao meio-dia.

À Capes, pela bolsa-sanduíche de seis meses que me possibilitou um importante período de estudos em Paris.

Ao Conseil Régional de l'Île-de-France, pelo subsídio de apoio à cotutela.

Aos membros do júri, pelas sugestões valiosas.

E, em especial, à Fernanda que sempre esteve ao meu lado nas piores dificuldades, e sem a qual este trabalho talvez nem tivesse vindo à luz. 
Esta tese é dedicada à minha mãe e aos meus irmãos 


\section{Resumo}

A conduta criativa de João Cabral de Melo Neto é tradicionalmente caracterizada como uma atividade controlada por uma "razão arquitetônica", que lucidamente projeta, e rigorosamente realiza a obra literária. A abordagem, aqui feita, de seu pensamento sobre a criação quer dizer, das representações do fazer em seus poemas metalinguísticos - e também de sua prática criativa - legível nos traços de seus manuscritos - afasta-nos sensivelmente do paradigma da arquitetura. Em seu lugar, propomos considerar o fazer cabralino como uma atividade de reformulação constante, que produz, durante o processo de escrita, novos sentidos e estruturas não determinados $a$ priori, integrando, dessa forma, a imprevisibilidade e a instabilidade na essência mesma da criação literária.

\section{Palavras-chaves}

- João Cabral de Melo Neto

- Português (Literatura Brasileira)

- Criação poética

- Poiética, genética textual, reformulação textual

- Razão arquitetônica, imprevisibilidade, instabilidade 


\section{Résumé}

La conduite créatrice de João Cabral de Melo Neto est traditionnellement caractérisée comme une activité contrôlée par une « raison architectonique », qui projette avec lucidité et réalise avec rigueur l'œuvre littéraire. L'abordage fait, dans ce travail, de sa pensée de la création - c'est-à-dire, des représentations du faire dans ses poèmes métalinguistiques - et aussi de sa pratique créatrice - repérable dans les traits de ses manuscrits - nous éloignent sensiblement du paradigme de l'architecture. Au lieu de ce paradigme, nous préférons considérer le faire de João Cabral de Melo Neto comme une activité de reformulation constante, qui produit, au cours du processus d'écriture, de nouveaux sens et structures qui n'étaient pas déterminés à priori, en intégrant, de cette façon, l'imprévisibilité et l'instabilité à l'essence même de la création littéraire.

\section{Mots-clés}

- João Cabral de Melo Neto

- Portugais (Littérature Bresilienne

- Création poétique, poḯtique

- Génétique textuelle, reformulation textuelle

- Raison architectonique, imprévisibilité, instabilité. 


\begin{abstract}
João Cabral de Melo Neto's creative conduct is traditionally characterized as an activity directed by an "architectonic reasoning", which consciously projects and rigorously realizes the literary work. The approach taken here of his creative thinking - that is, of the representations of the act of making in his metalinguistic poems - and of his creative practice - which is discernible on the glyphs of his manuscripts - takes us sensibly away from an architectural paradigm. Instead, we propose to consider Cabral's making act as a constant reformulation activity, which produces, during the writing process, new meanings and structures not determined a priori, in this way integrating imprevisibility and instability to the very essence of literary creation.
\end{abstract}

\title{
Keywords
}

- João Cabral de Melo Neto

- Portuguese (Brazilian Literature)

- Poetic creation, poietics

- Genetic critiscim, textual reformulation

- Architectonic reasoning, imprevisibility, instability. 
Escrever jamais é sabido;

o que se escreve tem caminhos.

João Cabral de Melo Neto 
INTRODUÇÃO 
A finalidade deste trabalho é analisar e interpretar dois objetos distintos, mas complementares: primeiro, o pensamento sobre a criação literária de João Cabral de Melo Neto, quer dizer, as diversas representações, em seus textos, do fazer literatura, e, segundo, sua conduta criativa, isto é, as diversas operações que punha em prática em sua atividade de escrita.

Essa abordagem será feita a partir de perspectivas epistemológicas ainda não exploradas pela crítica dedicada à sua poesia, quais sejam, a da poiética, enquanto ciência e filosofia das condutas criativas, e a da crítica genética, enquanto estudo do processo de criação literária através da interpretação de traços manuscritos ${ }^{1}$. Tais perspectivas, na medida em que propõem, por um lado, como é o caso da poiética, conceitos que determinam com mais exatidão a atividade criativa em geral, e, por outro lado - caso da crítica genética -, instrumentos para uma análise mais apurada de documentos manuscritos, tais perspectivas, dizemos, propiciam a apreensão de novos aspectos da concepção cabralina de criação e um conhecimento inédito do seu fazer, pois permitem trazer à tona uma documentação os prototextos de João Cabral - quase completamente ausente nos trabalhos sobre o poeta.

A crítica literária preocupou-se, sobretudo, com a poética de João Cabral de Melo Neto. Quer dizer, tanto com a dicção quanto com a ficção de sua poesia, ou, para utilizar os termos precisos de Gérard Genette, com suas "caractéristiques formelles" e seu "caractère

\footnotetext{
1 As definições de poiética e crítica genética aqui dadas - e às quais voltaremos adiante -, se baseiam nas de René Passeron e Almuth Grésillon. Ver, com relação à primeira, "Editorial", Recherches poiétiques, 1994, n 1, p. 6. Com respeito à segunda, ver o texto de GRÉSILLON, Almuth, "Nous avançons toujours sur des sables mouvants.' Espaces et frontières de la critique génétique ». La création en acte. Devenir de la critique génétique/dir. por Paul GIFFORD et Marion SCHIMD, Marion. Amsterdam : Rodopi, 2007, p. 29.
} 
imaginaire" 2 , além da relação entre ambas. E foi subordinada à reflexão sobre essa relação que a crítica pôs como objeto o fazer cabralino. Considerou-se a dicção da poesia de João Cabral - da qual os críticos não deixaram de apontar, com correção, os aspectos de ordenação simétrica de estrofes, medida proporcional dos versos, sintaxe elíptica, entre outros -, como o outro lado da moeda de sua ficção metalinguística - da qual a crítica valorizou, sobretudo, as figuras técnicas. Assim, nasceu o "poeta-arquiteto", ou "poeta-engenheiro", imagem preponderante da criação de João Cabral, que dá a ver o fazer literário como um trabalho de projeção lúcida de sentido e estruturas, seguida de uma rigorosa construção do poema, através de um processo de "mineralização", ou seja, do polimento da palavra de todas as arestas semânticas indesejadas.

Nosso trabalho terá como objetivo mostrar que as imagens da arquitetura ou da engenharia, bem como da mineralização, como representação da conduta criativa de Cabral, são por vezes ilusórias e necessariamente, parciais.

Por um lado, o que uma análise do pensamento cabralino sobre a criação, isto é, o que uma leitura poieticamente orientada dos poemas ditos "metalinguísticos" de João Cabral - poemas que têm por objeto a atividade de criação literária - nos mostra é que há em sua obra representações do fazer onde o imprevisível e o instável são integrados, representações, portanto, que relativizam o controle e a constância do procedimento arquitetônico. Essas representações se dão por meio de metáforas vitalistas, pela asserção da inevitabilidade do refazer, entre outras representações, que mostram a imagem de um sujeito criador

${ }^{2}$ GENETTE, Gérard. Fiction et diction. Paris : Seuil, 1991, p. 31. 
intranquilo às voltas com uma matéria não completamente domável por meio de reescritas incessantes.

Por outro lado, a análise dos traços manuscritos de sua prática criativa nos mostra que o fazer de João Cabral se constitui de operações reformulativas (parafrásicas, num sentido amplo ${ }^{3}$ ) cujo resultado, muitas vezes, são novas estruturas ou significações assimétricas, e não necessariamente a realização do equivalente linguístico de uma intenção clara e fixa. Isso faz com que, em muitos casos, a conduta cabralina seja mais processual que programática, ou mais trajetual que projetual. Além disso, se intenção programática e projetual há na conduta do poeta, será nosso objetivo também mostrar, por meio dos traços manuscritos, o trabalho de construção que foi levado a cabo.

A análise do pensamento poiético de Cabral e dos traços genéticos de sua conduta, bem como da articulação entre um e outro se fará nesta tese em três partes.

Na primeira parte, trataremos de explicitar nossos pressupostos metodológicos. O primeiro capítulo da primeira parte será dedicado à disciplina que suscitou nossa busca pelo pensamento sobre a criação. Enquanto ciência e filosofia das condutas criativas, a poiética emancipou - já com Paul Valéry - a atividade criativa (produção) como objeto epistemológico distinto da obra acabada (produto) e da atividade contemplativa (recepção), constituindo um campo de estudos próprio com o "Groupe de Recherches Esthétiques", depois nomeado "Groupe de Recherche en Philosophie de 1'Art et de la Création", dirigido por

\footnotetext{
${ }^{3}$ Almuth Grésillon e Jean-Louis Lebrave vêem a paráfrase, junto com a ambiguidade, na base de toda constituição de sentido, inclusive na escrita literária: "Ce que les dossiers génétiques montrent en plus, et sans doute mieux que les modèles abstraits ou les études sur l'oral, c'est que toute constitution du sens, loin d'être préétablie passe nécessairement par ces deux opérations [paraphrase e ambigüité]. Ver GRÉSILLON, Almuth, LEBRAVE, Jean-Louis. Paraphrases et ambiguïtés dans la production du texte littéraire. In : L'ambigüité et la paraphrase. Opérations linguistiques, processus cognitifs, traitements automatisés/ ed. por Catherine FUCHS. Caen : Centre de Publications de l'Université de Caen, 1988, p. 128.
} 
René Passeron. Os resultados das pesquisas, efetuadas, quase sempre, por "artistes-chercheurs", como é o caso de René Passeron, produziram um conhecimento mais exato da arte 4 ao tratá-la como "fenômeno de ateliê", descrevendo os lineamentos que põem em relação sujeito criador e obra que se faz, e inventando conceitos fundamentais para a consideração especulativa do fazer artístico. O desenvolvimento do conhecimento poiético implicou a desconstrução de vários mitos paradigmáticos da criação, inclusive o paradigma arquitetônico, ou eidético, que representa a poesis (produção, criação) como a materialização de um eidos (uma forma noética) que se mantém invariável no processo de execução. De fato, a poiética interessa-se francamente pelo que há de imprevisível na criação, e afirma categoricamente que a imprevisibilidade é constitutiva da atividade instaurativa. Essa disciplina tem aqui sua contribuição na medida em que desviou nosso olhar para textos de Cabral onde a criação é representada de uma maneira mais realista do que ideal, mostrando-se como um processo permeado de acidentes e transformações.

O segundo capítulo da primeira parte será dedicado à crítica genética. É a essa disciplina que devemos as ferramentas que nos serviram na análise dos prototextos de João Cabral, nos quais encontramos os vestígios manuscritos de seu fazer literário. O objeto da crítica genética são justamente as operações de constituição de sentido e estruturas $^{5}$, através da interpretação de documentos genéticos, ou "avant-textes", conforme a terminologia proposta por Jean Bellamin-

\footnotetext{
${ }^{4}$ Não nos esquecemos, e disso trataremos mais adiante, no $1^{\mathrm{o}}$ capítulo da $1^{\mathrm{a}}$ parte, das ambições antropológicas da poiética, já que esta põe como objeto de especulação a criatividade humana em todas as suas formas, para além da arte.

${ }^{5}$ Não nos esquecemos aqui que a crítica genética já produziu vários dossiês sobre artes outras que a literária - música, pintura, cinema etc. Ao interessado no conteúdo das diversas publicações, é vantajoso consultar a seguinte página virtual do ITEM (Institut des textes et manuscrits modernes): http:// www.item.ens.fr/index.php?id=13696.
} 
Noël6 - prototextos ou pré-textos, em tradução brasileira. Neste capítulo, pautando-nos em importantes pequisadores genéticos (Almuth Grésillon e Pierre-Marc de Biasi, por exemplo) apresentaremos as convenções que utilizamos para a transcrição dos manuscritos da obra de Cabral, que pudemos consultar no arquivo pessoal do autor localizado na Fundação Casa de Rui Barbosa. Apresentaremos também, num segundo momento, nossa base analítica, que é fundamentalmente linguística, largamente adotada por inúmeros geneticistas. Essa abordagem estará atenta sobretudo à operação mais comumente apreensível nos prototextos de Cabral, a reformulação parafrásica. A determinação conceitual da operação de paráfrase, bem como dos meios para sua análise, estará calcada principalmente na teoria de Bernard Pottier e na teoria da paráfrase concebida por Catherine Fuchs, teorias que descrevem o fenômeno de reformulação como produção de equivalências e assimetrias semânticas. Será exatamente esse fenômeno, tão frequente nos documentos genéticos de Cabral, que analisaremos mais detalhadamente na terceira parte.

No terceiro capítulo da primeira parte, debateremos rapidamente a relação possível entre a poiética e a crítica genética, pondo em confronto seus resultados teóricos. Embora ambas praticamente se ignorem, nosso esforço será de pensá-las conjugadas por uma maior inteligibilidade do fazer literatura, já que uma - a poiética -, por um lado, objetiva diretamente o ato criativo, e a crítica genética - por outro lado -, o traço desse ato.

A segunda parte concernirá ao pensamento cabralino sobre a criação, ou seja, à representação do fazer literário na obra de João Cabral, bem como à interpretação desse pensamento proposta pela crítica literária. $\mathrm{O}$ primeiro capítulo examinará exatamente a recepção

\footnotetext{
${ }^{6}$ BELLAMIN-NOËL, Jean. Le texte et l'avant-texte. Paris: Larousse, 1972.
} 
crítica. Tratar-se-á de fazer a genealogia da imagem do "poetaarquiteto", ou "poeta-engenheiro", que vemos ser constituída desde os primeiros textos sobre o poeta (de Antonio Candido) até teses mais recentes. Essa metáfora, que foi valorizada especialmente pela recepção concretista de João Cabral, representa o fazer a partir de uma estrutura rigidamente construtivista: o poeta conceberia lucidamente sua obra e a realizaria rigorosamente conforme a forma concebida, através da transformação da "palavra em pedra". Grande parte dos comentadores, ao pensarem o processo compositivo a partir da estrutura final do poema e destacando as figuras técnicas da criação presentes na obra de Cabral, fomentou abundantemente a interpretação construtivista da criação cabralina.

No segundo capítulo, empreenderemos uma leitura poieticamente orientada dos poemas metalinguísticos do livro $O$ engenheiro (1945), bem como de "Fábula de Anfion" e "Psicologia da composição" (ambos de 1947) com o intuito de mostrar o quanto, aí, a representação do fazer integra valores diversos dos arquitetônicos. A relação sujeito criador - obra que se faz é constituída, nessas obras, dentro de um espaço instável, o da página branca, lugar híbrido sinônimo de esterilidade e criação; e tal relação se representa dentro do domínio nocional da imprevisibilidade, como o atestam as metáforas vitalistas do poema que o figuram, por exemplo, como um "cavalo louco"; finalmente, o fazer, em tais textos, é muitas vezes modalizado como "intranquilo", dando-se a ver uma psicologia do sujeito criador distante da que representa a consciência poiética como portadora do total controle do resultado de seus atos instaurativos.

No terceiro capítulo, completaremos a interpretação poiética de parte da obra de João Cabral considerando, em um primeiro momento, seus textos teóricos sobre a composição, especificamente Joan Miró 
(1952) e "Poesia e composição" também de 1952. Nesses textos, veremos como João Cabral teoriza a criação a partir da ideia de inacabamento, ou seja, a partir da valorização do fazer em si mesmo, na medida em que este estaria esvaziado de toda teleologia prescritiva. $O$ escrever como reescrever indefinido (o fazer como refazer perpétuo) mostra como a composição de formas poéticas somente é decidida durante o processo elaborativo, e não exatamente em uma concepção a priori da obra. E esse fenômeno, como veremos, é próprio da condição histórica do poeta contemporâneo, individualista em seu procedimento, já que, em sua época, foi abolida toda regra preceptiva sociabilizada que pudesse lhe nortear teleologicamente. A ideia de uma instabilidade inerente à obra em processo, devida à sua elaboração contínua, é retomada por Cabral em diversos poemas publicados seja em Museu de Tudo (1975), seja em A escola das facas (1980), seja em Agrestes (1985), textos que não deixaremos de analisar.

Tendo considerado, na segunda parte, o pensamento de João Cabral sobre a criação, será a vez de, na terceira parte, tomar como objeto sua prática poética. Será através da análise dos prototextos de diversos poemas que interpretaremos os traços manuscritos de sua conduta criativa com a finalidade de caracterizar seu processo de constituição de sentido e estruturas. Depois de uma breve descrição do seu arquivo pessoal depositado na Fundação Casa de Rui Barbosa, analisaremos, em três partes consecutivas, os manuscritos referentes aos livros Serial (1962), A educação pela pedra (1966) e A escola das facas (1980). O critério de escolha desse material foi o fato de se tratar de documentos, dentre os localizáveis no arquivo do autor, com maior valor genético.

No primeiro capítulo, o exame da operação parafrásica presente nos prototextos de alguns poemas de Serial tentará dar a ver de que 
forma as diversas reformulações - mudança do título, reescrita de estrofes etc. -, mesmo depois da inteira composição do livro (com todas as suas partes já tendo sido inventadas e articuladas), implicam novas orientações não somente no nível mais discretamente semântico dos poemas, mas também no nível estrutural.

O segundo capítulo será consagrado aos manuscritos do livro $A$ educação pela pedra (1966), julgado como um dos mais arquitetônicos de Cabral. Em um nível macro e micro-estrutural, teremos a oportunidade de determinar o estatuto daquilo que alguns críticos chamam de "planta baixa" da obra7, com respeito ao processo de sua realização. Veremos que tal "planta", na verdade, somente foi feita por Cabral depois da composição dos poemas, o que problematiza sua função de projeto arquitetônico. Veremos também como durante o processo compositivo, através de operações reformulativas, João Cabral reestrutura diversos textos, redefinindo as relações das partes de alguns poemas entre si. Além disso, percebe-se, nos documentos genéticos de A educação pela pedra, através de marcas enunciativas, a presença da dúvida e do acaso no trabalho com o material linguístico. O prototexto de um poema metalinguístico ("Catar feijão"), que analisaremos detidamente, propiciará a oportunidade de comparar pensamento e prática criativa cabralinos tendo como referência um mesmo texto e seus manuscritos.

O terceiro capítulo da última parte tratará dos prototextos de poemas publicados no livro A escola das facas (1980). Três documentos serão privilegiados. Primeiro, o manuscrito do poema-abertura "O que

\footnotetext{
${ }^{7}$ Referimo-nos aqui ao documento publicado por Antonio Carlos Secchin na revista Colóquio-Letras, em um número dedicado a João Cabral de Melo Neto. Trata-se de um documento escrito pelo próprio poeta onde é apresentada a macro-estrutura do livro e a micro-estrutura de cada poema em particular. Ver Colóquio-Letras. Paisagem tipográfica. Homenagem a João Cabral de Melo Neto (1920 - 1990), 2000, nº 157/158, sem indicação de página.
} 
se deve dizer ao editor a propósito de poemas", na medida em que contém, acreditamos, uma descrição mais propícia do processo de criação poética, e que, assim, também oferece uma comparação vantajosa do pensamento poiético do autor com sua atividade elaborativa. Segundo, o manuscrito do poema "Prosas da maré na Jaqueira", cujo valor genético é enorme, pois temos aí uma exemplificação cabal de quanto o procedimento cabralino pode ser processual e não exatamente programático, devido à série de mudanças de ritmo, de modalização e de estrutura efetuada em pelo menos três campanhas de reescritas. Terceiro, o manuscrito do poema "Descoberta da literatura" que mostra como a escrita de João Cabral não se caracteriza somente pelo "corte", pelo "enxugamento", mas também pela expansão. Com efeito, nesse manuscrito as reformulações estendem o texto transformando profundamente a representação poética nele contida. Serão justamente os ajustamentos sucessivos presentes nestes três documentos genéticos o objeto de nossa abordagem, a fim de mostrar como o poeta, menos que conceber de antemão a obra, descobre-a, ou, talvez, reinventa-a no trajeto compositivo.

Todas essas análises da terceira parte terão como base os resultados a que chegaram vários críticos genéticos ao examinarem, em trabalhos diversos, o fenômeno da paráfrase, ou reformulação textual, nas páginas manuscritas de autores tais como Flaubert e Proust ${ }^{8}$, trabalhos aos quais nos referimos no segundo capítulo da primeira

\footnotetext{
8 Ver, por exemplo, sobre Proust, GRÉSILLON, Almuth et LEBRAVE, Jean-Louis. "Paraphrases et ambigüités dans la production du texte littéraire ", art. cit, et FUCHS, Catherine, "Éléments pour une approche énonciative de la paraphrase dans les brouillons de manuscrits ». In: La genèse du texte: les modèles linguistiques/ ed. por Louis HAY. Paris : Éditions du CNRS, 1982. Sobre Flaubert, ver, por exemplo, FUCHS, Catherine, GRÉSILLON, Almuth, LEBRAVE, Jean-Louis, "Flaubert: 'ruminer Herodias'. in : Genèse et variation textuelle/ed. por Louis HAY. Paris : Éditions du CNRS, 1991.
} 
parte. Em nossa análise dos prototextos cabralinos, uma vez identificado que a paráfrase é o procedimento por excelência da escrita do poeta pernambucano, teremos por objetivo, analisando as equivalências e as assimetrias semânticas instauradas por essa operação, ver até onde as diversas reformulações produzidas correspondem a um sentido projetado e quando ultrapassam o "limite de distorção"9 com relação à intenção original, instaurando novas formas e conteúdos.

Concluiremos afirmando que as novas perspectivas epistemológicas que baseiam este estudo proporcionam uma melhor compreensão da atividade criativa de João Cabral de Melo Neto. A vantagem dessas perspectivas é nos livrar de certas imagens ilusórias provindas de construtos hermenêuticos, cujo limite é pensar a conduta criativa do autor retrospectivamente, a partir do poema já acabado. Além disso, a critica genética, especialmente, possibilitando o estudo rigoroso dos manuscritos, abre o campo, também, para novas interpretações dos textos. Caber-nos-á mostrar como isso pode ser feito.

${ }^{9}$ A expressão é de Catherine Fuchs. Ver, da autora, Paraphrase et énonciation. Paris : Ophrys, 1992, p. 29. 


\section{PARTE 1. A CRIAÇÃO COMO OBJETO CIENTÍFICO}


Saídas da estética e do estruturalismo, a poiética e a crítica genética estabelecem a criação - quer dizer, atividade de trazer ao ser o que antes não era ${ }^{10}$ - em sua modalidade artística (poiética) e, especificamente, literária (crítica genética) como objeto científico, constituindo uma metodologia e um corpus analítico próprios.

A estética, que se define como teoria geral da sensibilidade humana diante das obras de arte e mesmo da natureza, "esconde", segundo René Passeron ${ }^{11}$, a factividade - o termo é de Etienne Gilson ${ }^{12}$ anterior a todo objeto artístico, pois este, antes de acabado, era um objeto

10 Não teremos, aqui, pudores terminológicos de utilizar a palavra criação e seus sinônimos - produção, [o] fazer, instauração, composição etc. - de forma indiscriminada. No decorrer da tese, no entanto, diremos alguma coisa sobre o esforço de René Passeron de bem distinguir a gramática dos conceito de criação e de produção (ver infra no primeiro capítulo desta primeira parte, onde comentaremos, do autor, algumas passagens sobre a questão, tiradas dos livros Pour une philosophie de la création. Paris: Klincksieck, 1989, pp. 155-163, e La naissance d'Icare: élements d'une poiétique général. Valenciennes: ae2cg Editions, 1996, pp. 26-35). Quanto à definição mais fundamental de criação, quer dizer, a atividade de trazer ao ser o que antes não era, pode-se encontrá-la em Platão. O termo utilizado pelo filósofo é poiesis, que se traduz comumente por produção, fazer ou fabricação. Confiram-se as traduções francesa e italiana da definição (PLATÃO. Le sophiste. Traduction de Nestor Cordero. Paris: Flammarion, 1993 e Il sofista. A cura de Mario Vitali. Milão:Tascabili Bompiani, 1992):

“Lorsque quelqu'un a amené à la réalité quelque chose qui n'existait pas avant, nous disons de celui-ci qu'il « a produit » $(219$ b). [...] Nous avons appelé "productrice" [...] toute puissance qui devenait la cause de la génération ultérieure de quelque chose qui n'existait pas auparavant. (265 c).

"Ogni volta che un tecnico qualsiasi porti ad essere qualcosa che prima non era, diciamo che colui che porta ad essere, "fa" [...] La tecnica de produzione, nel suo complesso, è una potenza capace di portare ad essere cose che prima no erano."

Atente-se também para a definição de poiesis dada no Banquete : " tout ce qui est cause du passage du non-être vers l'être pour quoi que ce soit, voilà en quoi consiste la fabrication (poiesis) », Platão. Le banquet. Présentation et traduction de Luc Brisson, Paris : Flammarion, 2005, 205b.

11 PASSERON, René, Pour une philosophie de la création, op. cit., p. 11.

${ }^{12}$ GILSON, Etienne, Introduction aux arts du beau. Qu'est-ce que philosopher sur l'art?, Paris : Vrin, 1963, p. 25. A factividade diz respeito à ordem humana "de la production et de la fabrication sous toutes leurs formes". 
a ser feito. A conduta criativa, ou seja, a relação do artista com a obra em processo de instauração é justamente o objeto da poiética ${ }^{13}$.

O estruturalismo, por sua vez, impondo uma abordagem imanente da obra de arte literária, ou seja, objetivando os elementos que constituem o sistema interno e coerente da obra, excluía tudo o que fosse extrínseco a ela. A redescoberta do manuscrito pela crítica genética (que o analisa com instrumentos conceituais do estruturalismo ${ }^{14}$ ) permite sair do texto acabado e fechado nele mesmo e, segundo Almuth Grésillon, "reconstruire les étapes successives de la genèse du texte et les mécanismes qui soustendent sa production"15

Pode-se, portanto, dizer grosso modo que a poiética e a crítica genética são duas disciplinas que têm, na definição, o mesmo objeto - a criação, a gênese, o devir da obra. Veremos, porém, que o método de abordagem de tal objeto em uma e outra é diferente.

Além de estabelecerem para si o mesmo objeto, poiética e crítica genética são contemporâneas. A primeira começa a ser concebida ainda sem nome - no fim da década de 60. A poiética, que já nasce nomeada pelas mãos de Paul Valéry, somente se desenvolve plenamente no começo da década de 70.

A crítica genética, como toda ciência, é fruto do esforço de uma equipe de pesquisadores. Na passagem dos anos 60 para os 70, um grupo de linguistas, dos quais faziam parte, entre outros, Almuth Grésillon, Jean-Louis Lebrave e Louis Hay, começaram a desenvolver

13 PASSERON, René. Exclamations philosophiques, suivi de Thèmes. Paris : l'Harmattan, 2003, p. 223.

${ }^{14}$ A herança do estruturalismo assumida pela crítica genética é metodológica. Como afirma Almuth Grésillon: "Dans la mesure où toutes mes lectures procèdent pour l'essentiel de la comparaison entre, respectivement, une forme « $a$ » et sa réecriture en « $\mathrm{b} »$ (puis en $« \mathrm{c}$, « $\mathrm{d} »$, etc.) et qu'elles essaient systématiquement d'évaluer les identités et les différences entre $« \mathrm{a} » \mathrm{e}\langle\mathrm{b} »$ (puis $\langle\mathrm{b} »$ et $\langle\mathrm{c} »$, etc.), elles restent, mutatis mutandis, fidèles au principe structuraliste». Ver La mise em oeuvre. Itinéraires génétiques. Paris : Éditions du CNRS, 2008, p. 8.

${ }^{15}$ Idem, ibidem , p. 20. 
um método linguístico de análise dos manuscritos de escritores no antigo "Centre d'analyse des manuscrits modernes" (atual ITEM "Institut de textes et manuscrits modernes"), ligado ao Centre national de recherche scientifique (CNRS). O grupo logo desenvolve progressivamente uma metodologia e um corpo de princípios e conceitos comuns para uma disciplina nova, batizada em 1979, por Louis Hay, de "critique génétique"16. A contribuição conceitual de Jean Bellemin-Noël, que propõe e define o termo "avant-texte" (prototexto ou pré-texto), - material mesmo do crítico genético -, em seu livro Le texte et l'avant-text (1972)17, é incontornável, ainda que o autor desenvolva uma análise antes psicanalítica que linguística ${ }^{18}$.

Hoje em dia, a crítica genética é ampla e internacionalmente reconhecida. No Brasil, especificamente em São Paulo, encontram-se vigorosas investigações no campo da genética textual, seja na Universidade de São Paulo - USP, animadas por Philippe Willemart, Cláudia Amigo Pino e Roberto Zular, seja na Pontifícia Universidade Católica - PUC-SP, por Cecília Almeida Salles ${ }^{19}$.

\footnotetext{
16 Hay, Louis, "Critique génétique: origine et perspectives". In: Essais de critique génétique/ed. por Louis HAY. Paris : Flammarion, 1979.

17 Daremos a definição aqui, à qual voltaremos na segunda parte deste capítulo. O "avant-texte" é "l'ensemble constitué par le brouillons, les manuscrits, les épreuves, les 'variantes', vu sous l'angle de ce qui précède matériellement un ouvrage quand celui-ci est traité comme un texte, et qui peut faire système avec lui" (BELLAMINNOËL, Jean. Le texte et l'avant-texte. Paris: Larousse, 1972, p. 15) Veremos que tal definição é criticada por Almuth Grésillon na medida em que pode levar a pensar que a finalidade última da crítica genética é o texto; ora, seu objeto é bem diferente: trata-se da escrita, do processo de produção e não do produto.

18 Sobre a origem e o desenvolvimento da crítica genética ver GRÉSILLON, Almuth, La mise en oeuvre, op. cit., pp. 19-24; LEBRAVE, Jean-Louis, "La critique génétique: une discipline nouvelle ou un avatar moderne de la philologie ? ", Genesis, 1992, n 1, pp. 33-72; e HAY, Louis, A literatura dos escritores. Questões de crítica genética. Belo Horizonte : UMFG, 2007.

19 De Philippe Willemart, ver Critique Génétique: pratiques et théories. Paris: L'Harmattan, 2007; de Cláudia Amigo Pino e Roberto Zular, Escrever sobre escrever. Uma introdução crítica à crítica genética. São Paulo: Martins Fontes, 2007; e de Cecília Almeida Salles, Redes de criação: construção da obra de arte. São Paulo: Editora Horizonte, 2006. Teremos a oportunidade de retomar particularmente as críticas de Cláudia Amigo Pino e Roberto Zular ao conceito de processo, central na teorização da genética textual.
} 
Com relação à poiética, é certo que sua fundação ocorre nos anos 30, com Paul Valéry. Mas, tendo permanecido, no início, dentro dos limites da obra do escritor francês, é somente no começo dos anos 70 que se desenvolve com vigor, quando um outro grupo de pesquisadores decide retomar seus príncipios e aumentar-lhe a abrangência especulativa. Seu texto re-fundador é justamente intitulado “La poïétique”, de René Passeron, publicado em 197120. O autor dirige, a partir de 1972, o "Groupe de Recherches Esthétiques" do CNRS, que logo se renomeou "Groupe de Recherche en Philosophie de l'Art et de la Création", ligado não somente ao CNRS, mas também à Universidade de Paris 1. O grupo, nas décadas de 70 e 80, publica diversas obras coletivas ${ }^{21}$; na década de 1990 organiza colóquios internacionais $^{22}$ e funda uma revista, Recherches poḯtiques, que é publicada de 1995 até o ano 2000, num total de nove números ${ }^{23}$. No Brasil, o desconhecimento da poiética é quase completo ${ }^{24}$.

Este pequeno itinerário das duas disciplinas mostra que ambas nasceram no mesmo lugar (no CNRS), e quase ao mesmo tempo. Mas apesar disso e ainda que seus objetos sejam os mesmos - a atividade criativa, mas com bases epistemológicas diferentes -, não há um verdadeiro debate científico entre ambas. Há, antes, senão um grande desconhecimento, uma certa disputa sem debate pelo poder-saber, na

20 PASSERON, René. La poḯtique, Revue d'esthétique, 1971, no 3. Retomado em Recherches poïétiques. Tome 1: la poïétique. Paris: Klincksieck, 1975, e em Pour une philosophie de la création, op. cit.

21 Recherches poḯtiques. Tome I: la poïétique. Paris: Klincksieck, 1975 ; tome II : le materiau. Paris: Klincksieck 1976; tome III : la création collective. Paris: Clancier Guénau, 1981 ; tome IV: Création et répétition, Paris : Clancier Guénau, 1982 ; tome V : la présentation. Paris : CNRS Éditions, 1985.

22 Cf. Poiétique. Paris: Ed. Poḯsis, 1991; Poïétique et culture. Sfax, Biruni, Paris: Arcantère, 1994 ; Le mode mineur de la création. Nice : Z'Éditions, 1995.

${ }^{23}$ Cf. Recherches poḯtiques, 1995 - 2000, ns 1- 9. Valenciennes : ae2cg Éditions.

${ }^{24}$ Uma pesquisa que efetuamos na internet mostra que René Passeron, pelo menos uma vez, esteve na Universidade Federal do Rio Grande do Sul, e deixou publicado o texto "Da estética à poiética", Revista do Instituto de Artes/UFRGS, 1997, vol. 8. n 15 . O texto foi retomado na revista Recherches poiétiques, 1998/1999, nº 8. 
medida em que a poiética, mesmo se querendo uma antropologia geral ${ }^{25}$, considera a criação artística como exemplar, e a crítica genética, ainda que seus maiores resultados estejam no campo literário, estendese a outros domínios artísticos ${ }^{26}$. Pensamos, porém, que ambas podem contribuir para um conhecimento mais exato do processo criativo em literatura.

Nesta primeira parte, antes de tratarmos da relação entres ambas disciplinas, faremos uma apresentação de suas bases epistemológicas. $\mathrm{O}$ primeiro capítulo terá como objeto a fundação da poiética, por Paul Valéry, e seu posterior desenvolvimento na obra de René Paseron. O segundo capítulo, por sua vez, terá por finalidade apresentar os métodos de transcrição e interpretação dos manuscritos literários utilizados pela crítica genética. Finalmente, no terceiro capítulo, as duas disciplinas terão confrontados seus princípios conceituais.

${ }^{25}$ Cf. supra nota $\mathrm{n}^{\mathrm{o}} 4$, e infra neste primeiro capítulo da primeira parte.

${ }^{26}$ Cf. supra nota ${ }^{\circ} 5$. 


\section{Capítulo 1. A poiética como ciência e filosofia das condutas criativas}

\section{1. Paul Valéry e a fundação da poiética}

Nesta parte, trataremos da instauração e do desenvolvimento da poiética como ciência e filosofia das condutas criativas, apoiando-nos em alguns textos fundamentais de Paul Valéry ${ }^{27}$, seu reconhecido fundador, e na obra de René Passeron, principal protagonista da posterior retomada da disciplina.

Os textos de Paul Valéry a que nos referimos são aqueles em que se pronuncia pela primeira vez a palavra "poiética" com pretensões científicas: o "Discours sur l'esthétique" e a "Première leçon du cours

\footnotetext{
${ }^{27}$ A referência a Paul Valéry nesta tese não implicará uma comparação de sua obra com a de João Cabral de Melo Neto. Já tivemos oportunidade, em nossa dissertação de mestrado, de tratar da relação entre os dois a partir da análise intertextual de três poemas de João Cabral dedicados ao escritor francês: "A Paul Valéry", de $O$ engenheiro, "A insônia de Monsieur Teste" de Museu de tudo, e "Debruçado sobre os cadernos de Paul Valéry" de Agrestes. A análise apontou para certas imagens poiéticas, algumas retomadas nessa tese, que qualificam a criação, em ambos os autores, como um processo não de todo racional e controlado. Essas imagens são a da intranquilidade do fazer, a do excesso de lucidez, que esteriliza o criar, e a do caráter "sujo" da escrita, que segue, por vezes, caminhos tortuosos. Cf. ROCHA, Francisco José Gonçalves Lima. La poétique de João Cabral de Melo Neto. Poèmes sur des écrivains français. Master 2: Études Portugaises, Brésiliennes et de l'Afrique Lusophone, sob a orientação de Maria Helena Araújo Carreira: Universidade de Paris 8, 2006. Nosso mestrado, dessa forma, difere sensivelmente do de Claudina Fialho de Carvalho para quem os dois poetas conjugam o mesmo princípio compositivo calcado no "pensamento lúcido" e no "aproveitamento planejado dos recursos da linguagem". Ver CARVALHO, Claudina Fialho de. Em perfil: João Cabral de Melo Neto e Paul Valéry. Dissertação de mestrado: Língua e literatura francesa: Universidade de São Paulo, 2004.
} 
de poétique" 28 , onde podemos depreender alguns "fondements d'une philosophie des conduites créatrices", segundo o comentário de um poieticista $^{29}$.

A poiética é emancipada como ciência autônoma, conforme se depreende dos textos de Paul Valéry, quando se determina 1) seu objeto e o domínio de pesquisa correspondente 2) o método de conhecimento desse objeto e 3) uma estrutura geral desse objeto.

Em primeiro lugar, portanto, trata-se da positivação da autonomia da poiética através da distinção de seu objeto e de seu domínio de pesquisa. No texto de Valéry referido acima, o "Discours sur l'esthétique", numa tentativa de classificar os diversos resultados da disciplina sobre a qual discorre, a Estética, o autor distingue dois grandes campos de pesquisa. O primeiro ele o chama de "estésico" e diria respeito a tudo o que “se rapporte à l'étude de la sensation" e mais particularmente aquelas “qui n'ont pas un rôle physiologique uniforme et bien défini", como o prazer do Belo que não tem finalidade vital. $O$ segundo, por sua vez, englobaria os elementos intrínsecos à atividade criativa e é assim definido pelo autor:

Un autre tas assemblerait tout ce qui concerne la production des œuvres ; et une idée générale de l'action humaine complète, depuis ses racines psychiques et physiologiques, jusqu'à ses entreprises sur la matière ou sur les individus, permettrait de subdiviser ce second groupe, que je nommerais Poétique, ou plutôt Poïetique. D'une part, l'étude de l'invention et de la composition, le rôle du hasard, celui de la réflexion, celui de l'imitation; celui de la culture et du milieu; d'autre part, l'examen et l'analyse des techniques, procédés, instruments, matériaux, moyens et suppôts d'action. ${ }^{30}$

${ }^{28}$ Cf. VALÉRY, Paul, Oeuvres 1. Paris: Gallimard, 1957, pp. 1294-1314 e pp. 1340-1358.

29 Referimo-nos a CONTE, Richard. "La poḯtique de Paul Valéry". Recherches Poiétiques, 1996, nº 5, p. 34.

30 VALÉRY, Paul, Oeuvres 1, op. cit. p. 1311. 
Se, por um lado, o campo estésico engloba tudo o que diz respeito à sensibilidade receptora - tenham as sensações funções vitais ou não -, ou seja, à relação do homem com uma obra ou qualquer outro objeto que lhe afeta, o campo poiético, por sua vez, diz respeito a tudo o que concerne à produção de obras. O campo poiético, na citação acima, é subdivido conforme uma ideia geral da ação humana. Essa subdivisão se dá em dois grandes conjuntos. O primeiro engloba tudo que diz respeito à psicologia e à cultura que condicionam a atividade produtiva; daí a ele estar ligado, como se lê acima, o estudo da "invenção", da "composição', e as funções desempenhadas pelo “acaso", pela "reflexão", pela "imitação", a "cultura" e o "meio". O segundo engloba os elementos técnicos próprios de cada produção particular, estando a ele ligado o exame e a análise "des procédés, instruments, matériaux, moyens et suppôts d'action".

$\mathrm{O}$ que os poieticistas aproveitarão desse programa é o corte epistemológico operado por Valéry que distingue a poiética enquanto campo de pesquisa específico, determinando e diferenciando seu objeto (a ação humana que produz obras) da sensação receptora, objeto do campo estésico. Ambos os campos, no entanto, - e nesse ponto os poieticistas posteriores se afastam de Valéry, como veremos adiante pertencem ao domínio maior da estética, na medida em que a criação, para Valéry, é também uma certa sensibilidade, uma sensibilidade criadora, como afirma Dominique Chateau em comentário à paisagem citada acima ${ }^{31}$.

Para o mesmo comentarista, que segue interpretando o texto de Valéry, o campo de pesquisa da poiética - teoria geral do fazer, entendido como sensibilidade criadora - tem uma extensão tão grande quanto o campo de pesquisa da estética - teoria geral da sensibilidade

${ }^{31}$ CHATEAU, Dominique, "Poïétique et esthétique", Recherches poïétiques, 1996, no 5, p. 49. 
receptora -, ou seja, ilimitada, mas ambos diferem em seus pontos de vista:

On peut dire que poïétique et esthétique rivalisent dans la mesure où elles mettent en avant un point de vue différent sur les objets naturels ou culturels. Là où la première privilégie la création, la fabrication, la seconde privilégie la réception, la perception; la première s'applique à des activités, la seconde définit des attitudes. ${ }^{32}$

Assim, entre poiética e estética haveria uma diferença de perspectiva, de olhar epistemológico dirigido sobre os mesmos objetos: a estética se localiza no montante do processo artístico, o qual tem a seguinte estrutura produção $\rightarrow$ obra $\rightarrow$ recepção, tomando como objeto perceptos e afetos resultantes de uma relação contemplativa com a obra de arte. A poiética, por sua vez, localiza-se na jusante desse mesmo processo, privilegiando condutas e operações constituintes de uma atividade que, incidindo sobre um material, instaura obras.

No segundo texto de Paul Valéry aqui considerado,"Première leçon du cours de poétique", encontramos também uma generalização e uma distinção espistemológica da poiética. Mas tal distinção não ocorre dentro da estética, ciência geral da sensibilidade, mas com relação à poética, sendo esta assim definida pelo autor:

On entend ordinairement ce terme [poétique] de tout exposé ou recueil de règles, de conventions ou de préceptes concernant la composition des poèmes lyriques et dramatiques ou bien la construction des vers ${ }^{33}$.

A esse sentido de poética como disciplina prescritiva, Paul Valéry opõe o sentido "tout primitif" de "poiética" justamente expresso na etimologia da palavra. Como afirma o autor:

32 Idem, ibidem, p. 50.

33 VALÉRY, Paul, Oeuvres 1, op. cit. p. 1341. 
Le faire, le poïein, dont je veux m'occuper, est celui qui s'achève en quelque œuvre et que je viendrai à restreindre bientôt à ce genre d'œuvres qu'on est convenu d'appeler œuvres de l'esprit. Ce sont celles que l'esprit veut se faire pour son propre usage, en employant à cette fin tous les moyens physiques qui lui peuvent servir ${ }^{34}$.

Na passagem acima, Valéry se esforça por determinar um objeto científico específico, o fazer, que assume uma generalidade considerável quando associado a todas as "obras do espírito". O fazer, "a ação que faz", e sua ciência, a Poiética, nome forjado para fazer sobressair a etimologia da palavra - do grego poïen, produzir, fazer - se distingue agora da disciplina que regra, através de preceitos, a composição de obras, qual seja, a Poética. Richard Conte vê nessa distinção a extensão da pretensão valeryana, que teria proposto não apenas uma poiética literária, mas uma poiética geral, uma ciência que se estenderia a todos os domínios onde se trata de construir uma obra ${ }^{35}$.

Um dos primeiros fundamentos, portanto, da poiética, que pode ser haurido em Valéry, é a determinação de seu objeto, a ação produtora de obras, e de seu domínio de pesquisa, que englobaria todas as atividade humanas criativas, ou ao menos as que produzem "obras do espírito". Estaria em germe, nos textos de Paul Valéry uma ciência da factividade geral distinta da estética, teoria da sensibilidade geral.

O segundo ponto fundamental é de caráter metodológico. Como apreender intelectualmente o objeto da poiética, a ação que faz? Esse método é, como o formula Richard Conte, a partir de Paul Valéry, o de “auto-poïesis, ou l'analyse de l'esprit en acte"36. Na verdade, a autoobservação, ou "consciência da consciência" criadora é uma atitude metodológica de certa maneira generalizada pelo autor dos Cahiers: “ce que nous pouvons véritablement savoir ou croire savoir en tous

\footnotetext{
34 Idem, ibidem, p. 1342.

35 CONTE, Richard. La poïétique de Paul Valéry, art. cit. p. 35.

${ }^{36}$ Idem, ibidem, p. 41.
} 
domaines, n'est autre chose que ce que nous pouvons ou observer ou faire nous-mêmes" 37 . Assim, o conhecimento da ação que faz passa pela reflexão analítica do artista sobre sua própria conduta criativa, no momento mesmo que ocorre. Brian Stimpson descreve essa posição valeryana, deixando claro que a introspecção poiética é inspectiva, objetivando o instante da criação, e não retrospectiva, reproduzindo o processo instaurativo:

Il est ainsi question de saisir la genèse du développement de l'écriture $\mathrm{du}$ poème, non selon une perspective rétrospective para rapport au texte définitif, mais selon la dynamique, l'invention et la logique de chaque situation actuelle, de chaque moment dans le contexte de son passé et de son futur immédiat 38

Essa introspecção inspectiva, procedimento metodológico fundamental da poiética não somente valeryana, mas de toda poïética posterior, será exatamente um dos aspectos da conduta criativa de Paul Valéry mais valorizados por João Cabral, ele mesmo permanentemente autopoiético. No poema "Debruçado sobre os cadernos de Paul Valéry", incluído no livro Agrestes, Cabral se refere à "coragem" do autor dos Cahiers de "viver em frente da imagem/ do que faz, enquanto faz". O resultado da reflexão dessa consciência da consciência criadora é propiciar um visão mais justa do processo de feitura, que, como afirma ainda o poema, não segue um teleologia em linha reta, mas, ao contrário é "sujo", "difuso", "reto e curvo"39.

Paralelamente a essa atitude auto-reflexiva do próprio sujeito criador que apreende seus atos criativos concomitantemente à execução da obra, há também, em Paul Valéry, como nota Richard Conte, a

\footnotetext{
37 VALÉRY, Paul, Oeuvres 1, op. cit., p. 1346.

38 STIMPSON, Bryan. Paul Valéry, l'écriture en devenir. Bruxelles: Peter Lang, 2009, p. 21.

${ }^{39}$ MELO NETO, João Cabral de. Obra completa. Rio de Janeiro: Editora Nova Aguilar, 2006, pp. $559-560$.
} 
observação da conduta criativa alheia, observação que o autor integrava à sua pesquisa poiética. Depois de dar a arquitetura (Eupalinos), a pintura (Degas Danse Dessin), e a escultura (Mon Buste), como exemplos, Richard Conte afirma: “on pourrait multiplier les citations démontrant que Valéry adopte une posture poïétique dans tous les domaines où il s'agit de construire une œuvre." 40

Dessa forma, temos, de um lado, a reflexão sobre a a própria criação em devir; de outro lado, a observação de processos criativos outros em todos os domínios artísticos. A conjugação dessas duas atitudes críticas constitui a metodologia valeryana de uma ciência possível da criação, de uma poiética.

À emancipação epistemológica da poiética, através da determinação da especificidade de seu objeto, a ação que faz, e ao estabelecimento de sua metodologia como auto-poiesis e estudo das condutas criativas de outros artistas, podemos acrescentar um terceiro ponto fundamental da instauração da poiética por Paul Valéry. Trata-se da proposição de uma estrutura geral da ação produtora de obras. Tal estrutura é apresentada pelo autor nos seguintes termos, em seu texto "Première leçon du cours de poétique":

Tout ceci se résume en cette formule que: dans la production de l'oeuvre, l'action vient au contact de l'indéfinissable.[...]

Ainsi d'une part l'indéfinissable, d'autre part une action nécessairement finie ; d'une part un état, parfois une seule sensation productrice de valeur et d'impulsion, état dont le seul caractère est de ne correspondre à aucun terme fini de notre expérience ; d'autre part, l'acte, c'est-à-dire la détermination essentielle, puisqu'un acte est une échappée miraculeuse hors du monde fermé du possible, et une introduction dans l'univers du fait ${ }^{41}$

${ }^{40}$ CONTE, Richard. La poiétique de Paul Valéry, art. cit. p. 35.

${ }^{41}$ VALÉRY, Paul, CEuvres 1, op. cit. p. 1357. 
A criação é, assim, para Paul Valéry, a saída de um estado de virtualidade (o pensamento, a sensação) para um universo de necessidade (a elaboração da obra) através de uma série de atos de determinação (a escrita, a pincelada): eis a estrutura geral da ação produtiva. O poeta, por exemplo, como afirma ainda Valéry, deve fazer agir a mão para sair de um campo interior de modificações desordenadas que somente a inscrição - feliz ou não - na folha em branco, enquanto "action extérieure", resolverá materialmente ${ }^{42}$.

Detenhamo-nos um pouco sobre essa estrutura da ação produtora. Depreendemos aí três elementos fundamentais: o "estado indefinível", a consciência reflexiva e os atos de realização. Richard Conte, comentarista da noção de poiética em Paul Valéry, determina a noção de "estado indefinível" como aquilo que antecede o ato instaurador, enquanto "état virtuel, le potentiel dont chaque esprit est chargé" 43 . aproximando-o, assim, da noção de "amplexe", do qual dá a seguinte definição, citando o próprio Valéry. “L'amplexe n'est pas activité, tout le contraire. Il est capacité. Notre capacité de sentir, de réagir, de faire, de comprendre [...] plus ou moins perçue pour nous - et toujours imparfaitement" ${ }^{\prime 4}$. No início do processo criativo haveria, portanto, esse fundo dinâmico do pensar, do sentir e do agir, presente em qualquer existência humana, e pertencentes ao campo da pura possibilidade. A passagem desse reino do arbitrário para o campo da necessidade se dá justamente pelo ato criador, "l'acte souverain de l'artiste ", nascido de uma " échange » entre " fins et moyens », " hasard e choix »., « substance et accident », « prévision et occasion », « matière

\footnotetext{
42 Idem, ibidem, p. 1351.

43 CONTE, Richard. La poïétique de Paul Valéry, art. cit. p. 39.

${ }^{44}$ VALÉRY, Paul. Oeuvres II. Paris: Gallimard, 1960, p. 234.
} 
et forme », " puissance et résistance ${ }^{45}$. $\mathrm{O}$ ato criador, como comenta Richard Conte, « introduit l'esprit dans l'univers du fait » ${ }^{46}$.

Se criar é passar constantemente de um estado virtual a uma realidade necessária, isso significa que o "estado indefinível" ou amplexo, subsiste permanentemente durante o processo e o atos instaurativos remetem a ele continuadamente. O comentário de Richard Conte pode ser lido nesse sentido:

Si l'implexe est capacité, Valéry le résume à "ce en quoi nous sommes éventuels". En fait, le champ des conduites créatices nous y renvoie en permanence, de l'oeuvre à faire à son impossible achèvement, en passant par l'implexe de chaque instant qui nous surprend à ce que nous sommes en train de faire. 47

A esse movimento entre ato determinativo e amplexo virtual está inextricavelmente ligada a auto-consciência poiética. Essa ligação é bem vista por Stimpson, quando o comentarista descreve o "temps de découverte réfléchie" intrínseco ao "poïen", ao fazer, seguindo letra e espírito de Paul Valéry:

[Le temps de découverte réfléchie] est marqué quant à lui par un effort pour saisir sur le vif l'opération des forces créatrices: tout en écrivant, l'écrivain voudrait s'observer en train de faire, voudrait capter l'écriture en acte. Saisi d'une vague irrésistible de création poétique, dont les traces abondantes se donnent à voir dans les dynamiques des pages manuscrites, l'écrivain ne peut s'empêcher de vouloir en même temps observer les opérations scripturales qu'il est en train d'employer. 48

Feitos tais comentários, a relação entre os três elementos fundamentais da ação produtora pode assim ser estabelecida, segundo

\footnotetext{
45 Idem, ibidem, p. 1221.

${ }^{46}$ CONTE, Richard, art. cit., p. 38.

47 Idem, ibidem, p. 39.

48 STIMPSON, Bryan. Paul Valéry, l'écriture en devenir. Bruxelles: Peter Lang, 2009, p. 92.
} 
a teoria de Paul Valéry: a passagem do estado virtual, onde emergem forças potencialmente criadoras, para o campo exterior de materialização da obra, por meio de um ato de determinação criativa, é atravessada por esse "tempo de descoberta refletida", conforme a expressão de Bryan Stimpson, tempo no entanto não contínuo, exceto por um esforço intenso e quase impossível de atenção constante, por meio do qual o olhar consciente vê as operações do espírito e do corpo que constituem o processo produtivo.

Eis portanto as condições fundamentais que possibilitam a poiética como ciência possível das condutas criativas, a partir dos textos de Paul Valéry:

1) a distinção de um objeto - a ação que faz - e de um domínio de pesquisa a ele correspondente. Atestando que toda obra é produzida antes que seja consumida, Valéry efetua um corte espistemológico dentro da estética, demarcando um domínio poiético - da produção de obras e um domínio estésico - do consumo de obras. A cada domínio corresponde uma perspectiva científica diferente .

2) o estabelecimento de uma metodologia para a compreensão do objeto. Tal metodologia, em Paul Valéry é a observação, por aquele que produz, de seu próprio processo criativo, ou, para utilizar um termo dos poieticistas, a auto-poiesis, conjugada com a observação das condutas alheias.

3) a proposição de uma estrutura fundamental da ação produtora. Para Paul Valéry essa estrutura se define pelos conceitos de estado indefinível - ou amplexo - e de ato criador, aos quais se imbrica a consciência da consciência poiética. Entende-se o primeiro como capacidade geral de sentir e pensar, e o segundo como a passagem dessa virtualidade do pensamento ou da sensação para a atualidade da elaboração da obra. Essa passagem é, em Valéry, constantemente 
acompanhada pela observação que faz o artista das próprias operações instaurativas. 


\section{2. René Passeron e o desenvolvimento de uma poiética geral}

O desenvolvimento da poiética, levado a cabo posteriormente por René Passeron, herda todo o espírito de Valéry e pouco de sua letra. Para uma comparação, apresentaremos a teoria de Passeron a partir das três proposições básicas para a instauração de uma filosofia das condutas criativas, tal como procedemos no subcapítulo anterior com relação à teoria valeryana da ação produtora: 1) a determinação de um objeto e de um campo de pesquisas autônomos, quais sejam, a conduta criativa e o campo poiético; 2) a proposição de uma metodologia para o conhecimento desse objeto e para a exploração desse campo; e, finalmente, 3) a exposição da estrutura da conduta criativa, discriminando-se os conceitos fundamentais que constituem a definição dessa conduta.

Em primeiro lugar, tratar-se-á, para René Passeron, de aprofundar o corte epistemológico efetuado por Paul Valéry e não mais distinguir a poiética dentro da estética, mas de instaurar um campo de pesquisa autonômo e distinto: instaurar a poiética é, como diz o autor, efetuar a "promotion philosophique des sciences de l'art que se fait" 49 . Promovida ao estatuto de ciência autônoma da arte sob a perspectiva do fazer, a poiética figura ao lado de dois outros campos, o das "sciences internes des oeuvres" (semiótica, estruturalismo) e o das "sciences de l'art qui est reçu" (estética). Cada um destes três campos objetiva a arte em geral a partir de três pontos de vista inconfundiveis, que

49 PASSERON, René. Pour une philosophie de la création, op. cit., p. 16. 
totalizam o fenômeno artístico - a criação, a obra e a recepção completando o quadro epistemológico das "sciences de l'art". ${ }^{50}$

René Passeron insiste sobretudo nas diferenças entre poiética e estética e afirma a possibilidade do pensamento da factividade como objeto científico. Com efeito, para o autor, haveria uma diferença ontológica entre a arte enquanto atividade criativa - a obra enquanto se faz - e a arte enquanto objeto acabado e de consumo. A diferença ontológica assim se exprime resumidamente: na estética a obra é para o receptor; na poiética, ela não é ainda, estando em vias de instauração pelo artista.

Os demais conceitos que distinguem ponto de vista poiético e ponto de vista estético partem de tal diferença. Podemos distinguir alguns deles a partir da seguinte proposição metafórica de René Passeron:

L'esthétique contemple l'émeraude et l'accapare, la poïétique en fait une bague pour l'offrir à une femme. ${ }^{51}$

Ou seja, do lado da estética encontramos a contemplação e a apropriação, do lado da poiética a feitura e a doação. Na medida em que a estética é fundamentalmente contemplativa e apropriadora, seu objeto, segundo René Passeron, é consideravelmente amplo; na verdade, como afirma o autor, é da “totalité de l'Univers qui vient à nous par le sens, le sentiment, le langage affectif" que se ocupam os esteticistas. O objeto da poiética é mais restrito. Para delimitá-lo, René Passeron efetua um trabalho de redução até alcançar a essência mesma daquilo que objetiva o poieticista. Acompanhemo-lo nessa reflexão redutora:

\footnotetext{
50 Idem, ibidem, p. 17

51 PASSERON, René. Exclamations philosophiques, suivi de Thèmes. Paris: L'Harmattan, 2003, p. 235.
} 
Or

dans cette totalité

la conscience critique distingue vite

la nature : ce ciel

la culture : cette ville ;

et, à l'intérieur de la culture,

l'art : ce palais.

Le champ de l'attention se réduit de plus en

plus,

jusqu'à telle œuvre, de tel art -

dont la question se pose alors de sa venue au monde.

*Le travail créateur du responsable devient

un objet d'étude.

Et cette étude s'appelle la POÏÉTIQUE

depuis Valéry.

C'est simple comme bonjour. ${ }^{52}$

A delimitação do objeto poiético começa com a distinção da realidade cultural com respeito à realidade natural, e, dentro do cultural, pela demarcação do que é obra artística, para, finalmente, ter diante de si o modo da "venue au monde" de tal objeto, o trabalho criativo responsável por sua instauração ${ }^{53}$. O trabalho criador que traz ao ser obras artísticas é, portanto, o objeto da poiética, e tal objeto tem elementos essenciais bem definidos, quais sejam, o sujeito criador e a obra enquanto é feita. Ambos mantêm entre si uma relação movente e evolutiva no sentido da instauração progressiva da obra, ainda que esta porventura não venha à luz. Nas palavras de René Passeron:

L'objet de la poïétique, ce n'est pas l'artiste, ce n'est pas l'oeuvre, c'est le lien mouvant évolutif pendant un certain temps qui lie l'artiste à son œuvre, son œuvre encore inachevée. ${ }^{54}$

\footnotetext{
52 Idem, ibidem, p. 92.

53 Para a retomada desse exercício de redução ver PASSERON, René. Regard critique et regard poḯtique. Recherches poiétiques, 1998, nº 7, pp. 7-11.

${ }^{54} \mathrm{Ou}$ ainda : “L'objet de la poïétique n'est pas l'auteur, ni l'œuvre, mais les linéaments qui mettent la conduite de l'auteur aux prises avec le devenir de l'œuvre en train.". PASSERON, René. Exclamations philosophiques, suivi de Thèmes, op. cit., p. 223).
} 
O objeto da poiética é, assim, o que se passa entre "l'oeuvre en train" e o sujeito criador, as operações e valores vigentes no "puro presente $^{\prime \prime 55}$ da atividade de criação, momento onde o artista tem diante de si um material que ele confronta no afã de que a obra chegue a seu termo.

Trateremos com mais vagar, adiante, dessa relação entre sujeito criador e obra que se faz. Por ora, a fim de terminar com a delimitação do campo de pesquisa poiético, lembremos que, muito embora considere a conduta artística como exemplar dentre as inúmeras manisfestações da criatividade humana, a poiética se quer uma teoria geral das condutas criativas. Segundo René Passeron, reclamada em todo domínio no qual o homem é criador, a poiética torna-se uma espécie de antropologia filosófica. Nas palavras do autor:

La poïétique tient le travail de création artistique pour exemplaire. Par suite, elle élargit sa perspective à toutes les activités instauratrices quelles qu'elles soient : la notion d'œuvre (comme fin) et d'art (comme moyen) deviennent des notions générales de l'anthropologie. ${ }^{56}$

A antropologia poiética é desenvolvida pelo autor sobretudo em seu livro La naissance d'Icare, onde sua ética da criação vai bem além do campo da ação humana produtora de obras de arte, até atingir todas atividades que exigem a mobilização da consciência criativa. É a própria instauração da civilização pelo homem - a "synthèse personelle et culturelle de la santé et de la vie de l'esprit" - que se torna, então, o

\footnotetext{
55 A expressão é de Thierry Lenain que, em seu ensaio " Le savoir historique comme paramètre objectif de la création artistique », pensa a complexa relação entre a história - que constroi séries temporais diacrônicas ou sincrônicas com a finalidade de apreender numa totalidade o diverso das obras artísticas - e a poiética, que considera o ato criador em seu "moment vivace ", na transcendência de seu "présent pur", que tende a escapar fenomenologicamente das imagens seriais que o historiador constitui com a ajuda de narrações referenciadas Ver "Le savoir historique comme paramètre objectif de la création artistique contemporaine", Recherches poiétiques, 1994, n 1, pp. 22-31.

${ }^{56}$ PASSERON, René. Pour une philosophie de la création, op. cit., p. 28.
} 
objeto de uma poiética geral. ${ }^{57}$ Interessados que estamos apenas na instauração da obra de arte, não trateremos aqui de tal amplitude especulativa. A conduta artística como exemplar, de qualquer forma, representa toda problemática dos processos criativos humanos em geral, inclusive a questão da responsabilidade inerente a qualquer ação poiética. No entanto, é preciso dizer que, no caso da instauração civilizatória, tal problemática é ainda mais gritante, já que se trata de ultrapassar a injustiça rumo à igualdade, a opressão rumo à liberdade, a doença rumo à saúde, processo que implica um atitude poiética de todos os seres humanos.

A teoria de René Passeron, portanto, como vimos acima, fundamenta a autonomia científica da poiética com relação às outras ciências da arte - as que tratam dos efeitos da obra sobre o receptor e as que objetivam as obras acabadas para descrever sua composição interna e semiótica - através de uma redução epistemológica cujo ponto de chegada é a pergunta pelo como e por que as obras foram feitas. A essa redução espistemológica está ligada uma definição ontológica da arte, na medida em que a poiética a considera com algo inacabado, em vias de instauração, e tenta compreendê-la na relações atuais do sujeito criador com a "oeuvre en train".

Em segundo lugar, a questão da metodologia, que retoma algumas proposições de Paul Valéry. Para esclarecer conceitualmente seu objeto, - as condutas criativas que produzem obras -, a poiética, segundo Passeron, constitui dossiês de ordem "positiva" e de ordem "introspectiva", integrados em uma ordem "normativa".

Com respeito ao primeiro tipo, o autor assim se expressa:

Au niveau d'une poïétique positive, elle adopte les méthodes de toutes les sciences humaines, aplliquées concurremment dans une sorte de

57 Idem. La naissance d'Icare, op. cit., p. 181. 
pluralisme. Les techniques le plus précises d'établissement des faits doivent lui permettre de constituer dossiers descriptifs dans les domaines qui la concernent. [...] La mise en système linguistique, le diagnostic psychanalytique ou la réinsertion matérialiste du cheminement de l'art dans son contexte historique ne sauraient être refusés : le dogmatisme négatif est aussi stérile que l'autre. Mais toute méthode à prétention explicative doit d'abord laisser être l'objet qu' elle étudie. Sinon elle installe devant lui un écran systématique, au lieu d'enrichir et éclairer scientifiquement son interprétation ${ }^{58}$.

Com respeito a essa ordem metodológica positiva, que é pluridisciplinar, alguns dossiês já foram constituídos pelos pesquisadores ligados ao Groupe de Recherche en Philosophie de l'Art et de la Création. Por exemplo, o primeiro número da revista Recherches Poiétiques reúne respostas à pergunta “L'histoire de l'art est-elle un ferment ou un obstacle pour la création ?". As diversas contribuições põem em relação o saber histórico e a conduta criativa, perguntando-se pelo uso poiético da história da arte e pela possível historicidade da atividade de criação. No primeiro caso, a história não é vista cumulativamente (como na história das obras de arte), mas em migalhas: («Je pense que, pour un créateur, comme pour l'adolescent, l'histoire de l'art est en miettes, et que, dans ce désordre, il cueille ce que Freud appelait des "embrayeurs des rêves" ${ }^{59}$ ). No segundo caso, o ato criador põe problemas à constituição de continuidades temporais, porque, comme escreve Thierry Lenain, ele ocorre na vibração de um puro presente que escapa à seriação histórica: "la production d'une oeuvre d'art s'opère dans la vibration d'un pur présent, dans un moment d'irruption irréductible participant d'une rupture dans le réseau des continuités" 60 .

No nosso caso, para o estudo da conduta criativa de João Cabral de Melo Neto, fizemos apelo sobretudo às teorias geneticamente

58 Idem. Pour une philosophie de la création, op. cit., p. 21.

59 Idem. Création et liberté: le défi de l'histoire. Recherches poïétiques, 1994, no 1, p. 14

60 LENAIN, Thierry, Le savoir historique..., art. cit., p. 27. 
orientadas, especificamente as baseadas em uma linguística da enunciação, na medida em que a constituição do sentido na criação literária ocorre por meio de operações de ajustamentos enunciativos que produzem equivalências e assimetrias textuais no processo de formulação da obra.

Com respeito à ordem metodológica introspectiva da poiética, assim se exprime René Passeron:

Il est possible de faire appel à l'introspection de l'artiste, aux descriptions exactes qu'il donne de son expérience, à l'analyse phénoménologique de ses rapports avec son œuvre. Les réticences en ce domaine sont notables. Dans un livre comme La vie secrète de Salvador Dali, le peintre ne consacre qu'une trentaine de lignes à la façon dont il travaille. Mais ces confidences, même parcimonieuses, sont utiles. Il est bon que le spécialiste de poïétique ait lui-même une expérience personelle de la pratique d'un art. Valéry a sans doute fondé la poïétique sur les réflexions que lui suggérait son travail de poète. 61

René Passeron ele mesmo já apresentara os resultados de seu próprio exercício de introspeção ao revelar-nos o processo de seu trabalho como artista plástico e como poeta ${ }^{62}$.

Aqui, se pensarmos em João Cabral de Melo Neto, encontramos um manancial para a pesquisa poiética. Pois o poeta, de uma maneira quase obsessiva, descreveu em poemas e textos teóricos a sua própria conduta criativa, bem como a de outros artistas. Porém, é preciso

61 PASSERON, René. Pour une philosophie de la création, op. cit. p. 21.

62 Com respeito a sua atividade plástica, pode-se consultar o ensaio intitulado "Inimages" constante do livro Pour une philosophie de la création, op. cit., pp. 133 - 146. Uma "inimagem" é uma imagem ao mesmo tempo negada e contida em uma imagem manifesta. Por exemplo, como explicita o próprio René Passeron, no quadro de Van Gogh, "Le pont de la grande jatte", percebe-se um rosto "sinistrement mélancolique" (p. 138). René Passeron procede extraindo tal imagem de onde ela se encontra (ele a corta de uma reprodução do quadro) e a utiliza em outra obra por meio da colagem. Com relação a seu trabalho de poeta, pode-se consultar as páginas 171-175 de La naissance d'Icare (op. cit.), onde o autor dá ver o processo de desvios e retificações sucessivas que o levaram à composição de seus Poèmes laconiques (Paris: Cahiers de l'atelier, 1995). 
distinguir as descrições exatas das ficções que servem à constituição de uma persona artística pública, ou de um ideal compositivo, que muitas vezes não correspondem completamente ao real processo de criação. Daí as "reticências notáveis", como afirma Passeron, quanto a esse método. A comparação da auto-descrições poiéticas com os manuscritos do autor, onde se lêem os traços de sua conduta, é, nesse sentido, esclarecedora. Ela nos leva, por exemplo, a adotar uma posição crítica com relação à representação do fazer poético cabralino como arquitetura, tão propalada pela crítica literária e, algumas vezes, pelo próprio autor. Se se entende o processo arquitetônico como um relação tal entre projeto e execução (desenho/canteiro), na qual o primeiro determina completamente o segundo, ele não se coaduna com a prática observável nos manuscritos de Cabral onde, em várias ocasiões, a forma poética somente é decidida durante a fase de realização. A essa aproximação entre poiética e genética voltaremos adiante, no terceiro capítulo desta primeira parte.

Os conhecimentos provenientes dessas duas vias metodológicas são integrados pela poiética em uma perspectiva normativa, como escreve René Passeron:

Enfim, à un troisième niveau, il faut intégrer cette connaissance des faits à une réflexion normative. [...] De même que la logique, au moins en ces deux espèces que sont la méthodologie et l'épistémologie, est une réflexion normative, menée parfois par le savant lui-même, sur la recherche du vrai, sur les moyens qu'il faut employer pour parvenir au vrai - et constitue donc des dossiers positifs d'ordre historique et d'ordre introspectif (ou auto-critique), puis couronne cela par une recherche des critères qui permettent d'arriver plus sûrement à la vérité -, de même, la poïétique, appuyé sur des faits précis, nous semble pouvoir être une réflexion normative sur l'activité instauratrice en général, et plus particulièrement sur l'activité instauratrice dans le domaine de l'art. ${ }^{63}$

${ }^{63}$ Idem, ibidem. 
Observe-se que, nessa citação, "normatividade" não tem o sentido de impor diretrizes prescritivas. Trata-se, exatamente, de determinar os valores vigentes na conduta criativa. Um artista não faz "n'importe quoi". Ele faz uma obra, e essa obra a fazer é o primeiro e principal valor que guia o artista, segundo René Passeron:

La conduite créatricre est une pensée en action, comme l'oeuvre sera, dès le niveau profond de son existence objectale, une pensée materialisée. À ce niveau, la valeur qui anime et justifie la conduite, c'est l'œuvre-même comme être en puissance" 64

A obra em potência, enquanto valor principal da conduta criativa, implica uma certa deontologia poiética: para que a obra seja feita - ou que pelo menos se tente fazê-la - deve-se agir conformemente a esse fim. O criador, assim, é comprometido pela obra que faz, e é o único responsável pelo seu devir. Ele se engaja na sua instauração física e eticamente, e sua ação poiética se baseia em princípios escolhidos de forma livre ${ }^{65}$. Essa reflexão normativa é fundamental no pensamento poiético de João Cabral de Melo Neto, e aponta, segundo o poeta, para uma problemática própria da criação contemporânea. Com efeito, uma vez que, como afirma Cabral ${ }^{66}$, a prática de criação literária atual ocorre na ausência de toda preceptiva sociabilizada, o escritor adota uma atitude de reescrita incessante sem teleologia definida. A contradição que resulta dessa atitude - refazer a tal ponto que o acabamento da obra fica ameaçado - é agudamente ponderada pelo poeta, e a ela teremos oportunidade de retornar no terceiro capítulo da segunda parte desta tese.

64 Idem. La naissance d'Icare, op. cit., p. 42.

${ }^{65} \mathrm{Idem}$, ibidem, p. 32.

66 O principal texto de João Cabral sobre a questão é "Poesia e composição" (Obra completa, op. cit., pp. 723 - 737). 
Finalmente, em terceiro lugar, já não encontramos, na poiética de René Passeron, a descrição da conduta criativa como a passagem de um estado de pura virtualidade para um campo de atualidade necessária através de um ato de determinação e de uma consciência reflexiva, tal como proposto por Paul Valéry. René Passeron vê nessa concepção do ato criativo uma centralização excessiva no sujeito que cria ${ }^{67}$. Ora, além do sujeito criador há a obra a fazer. E o objeto da poiética é justamente a relação entre um e outra. Essa relação é assim descrita pelo autor:

[un] ensemble de linéaments psychologiques, techniques et autres qui, dialectiquement, c'est-à' dire dans l'aller et le retour de l'oevre-en-train au sujet créateur, les relient temporairement l'un à l'autre ${ }^{68}$.

De um lado há o sujeito cujas ações são dirigidas eminentemente para a instauração da obra por vir. De outro lado, essa obra cuja principal característica é a de não existir ainda. Quais são as linhas essenciais - além do imperativo de criar o que não existe ainda - que ligam sujeito criador e aquilo que faz, quais são as operações efetuadas por tal sujeito no intuito de suprir o vazio inerente ao objeto a instaurar?

O sujeito criador preenche o vazio do "devant-être", como define René Passeron a obra em potência69, por meio da ação do trabalho criativo, que é, essencialmente, repetição ${ }^{70}$. Mas não se trata de

67 Ver PASSERON, René. Editorial. Recherches poïtiques, 1996, nº 5.

${ }^{68}$ Idem, La naissance d'Icare, op. cit., p. 170

${ }^{69}$ Idem, ibidem.

70 Ao criar, escreve René Passeron, "je repète aussi exactement que possible le même geste minime, sorte de quantum opératoire dans la continuité d'une instauration. La répétition est ici authentiquement poïétique, puisqu'à se passer delle, l'opération serait ratée, ou bien n'aurait pas lieu. [La répétition] prend place dans un processus intentionnel, qui n'est pas pour elle un vêtement, mais une voie. Relevant de l'activité, elle est l'effet d'une adaptation de l'intention instauratrice au matériau traité, et par là même, une condition essentielle de la technique opératoire" (Pour une philosophie de la création, op. cit., p. 75). O autor se refere aqui principalmente ao ato de raspagem sucessiva no processo de esculpir, mas a passagem pode servir perfeitamente para 
uma repetição qualquer, como precisa René Passeron na seguinte passagem:

Nous avons distingué [...] cinq sortes de répétitions : la répétition stérile (celle de Sisyphe), la répétition ascétique (celles de rites), la répétition intégrée (celles des gestes du travail, planter un clou), la répétition-avant (préparatoire ou prémonitoire), la répétition structurale (interne à l'œuvre, le leit-motiv). Parmi ces espèces, nous pouvons distinguer, avec Gilles Deleuze, « au-delà de la répétition nue et de la répétition vêtue, au-delà de celle à laquelle on soutire la différence et de celle qui la comprend, une répétition qui 'fait' la différence $» .71$

A repetição poiética por excelência é a que produz a diferença. As diversas operações criadoras são repetitivas, mas o resultado desse recomeçar incessante é a instauração de um estado da obra que diverge de seu estado anterior, e, sobretudo, do que era a obra em sua origem esquemática, esboçada e, mesmo, projetada. Nesse sentido, o conceito de repetição, na conduta criativa, é intrisecamente ligado a um outro lineamento que vincula sujeito criador e obra a fazer, e que se define pelo conceito de "desvio" (détournement). No desvio criador, muda-se o fim, permanecem os meios (tal como num desvio de rota feito por um avião, segundo o exemplo de René Passeron ${ }^{72}$ ), se bem que a renovação possa implicar um ajustamento e uma modificação, ainda que mínimos, dos meios ${ }^{73}$. A transformação da finalidade inicial por meio de um desvio criador, afirma Passeron, é "l'occasion d'une intensification

caracterizar o ato de reformulação textual, operação essencial da conduta de criação literária, repetitiva por excelência. Mas se trata de uma repetição que produz diferença, quer dizer, um texto assimétrico com relação ao texto anterior que foi reformulado. No curso dialético, de ida e volta entre obra a fazer e sujeito criador, a operação de reformulação acaba por revelar as adaptações constantes da intenção original do autor.

${ }^{71}$ Idem, Pour une philosophie de la création, op. cit. p. 159.

72 Idem. La naissance d'Icare, op. cit., p. 161.

${ }^{73}$ Idem, ibidem, p. 165. 
poïétique de l'opération créatrice essentielle"74, quer dizer, a conduta é tanto mais criativa na medida em que os atos de repetição a ela inerentes fazem diferir a intenção primeira durante $\mathrm{o}$ percurso instaurador.

Junto com o desvio criador, Passeron considera ainda a operação de "retificação" (rectification), como ato que liga dialeticamente o que a obra é em certo momento do trabalho, e o que ela deve ser na continuidade do poïen. Nas palavras do próprio autor:

Alors que le détournement diverge, la rectification, en tant que détournement detourné, ramène dans le droit chemin d'un projet créateur, même flou, une conduite qui ne veut pas s'égarer. La rectification semble [...] à l'opposée du détournement, une condutie normative de recentrage, de réorientation et de rigueur. ${ }^{75}$

A retificação, assim, é também um tipo de desvio, mas um desvio do desvio para reecontrar o bom caminho de um projeto criador. A retificação é a recuperação de uma intenção da qual o artista havia se apartado no decorrer do itinerário criativo. Esses dois tipos de operações poïeticas, desvio e retificação, enquanto repetições que fazem a diferença mostram, de qualquer forma, que não há um percurso em linha reta na atividade criativa. Apartando-se de um caminho anterior, através de um desvio, ou desviando-se do desvio, pela retificação, a conduta criativa é sempre um trajeto imprevisível. Essa poiética do trajeto é plenamente assumida por René Passeron, e se opõe a uma poiética do projeto, que o autor identifica na definição de trabalho humano dada por Marx:

Ce qui distingue dès l'abord le plus mauvais architecte de l'abeille la plus experte, c'est qu'il a construit la cellule dans sa tête avant de la

74 Idem, ibidem.

75 Idem, ibidem, p. 168. 
construire dans la ruche : le résultat auquel le travail aboutit pré-existe idéalement dans l'imagination du travailleur ${ }^{76}$.

Vê-se, pela citação, que, na poiética do projeto, a arquitetura é o paradigma por excelência da conduta criativa. E isso leva à afirmação que o fazer é um trabalho guiado pela pré-visão da obra final. Ora, para René Passeron, tal concepção é "étrangement fausse", porque a obra de arte é justamente "de celles que l'artiste prévoit le moins", sendo por isso, justamente, que ele a faz ${ }^{77}$.Temos aqui, portanto, o aspecto principal da atividade de criação: a imprevisibilidade. Daí a assunção, por René Passeron, da metáfora do trajeto: a conduta criativa é um percurso, de ida e volta, com desvios e desvios de desvios, entre o que é a obra e o que ela deve ser, por meio das operações instauradoras do sujeito que cria. Assim sendo, a instauração do opus se dá a cada passo do processo, já que o ponto de chegada da obra a fazer é ignorado pelo artista. É o que se pode ler nessa fórmula de René Passeron: “C'est l'imprévisible qui qualifie la poiesis comme conduite créatrice"78.

76 apud PASSERON, René. Pour une philosophie de la création, op. cit. pp. 121 - 122.

77 Idem, ibidem, p. 122.

${ }^{78}$ Idem, La naissance d'Icare, op. cit., p. 46. 


\section{3. Paradigma poiético versus paradigma eidético}

Nos dois subcapítulos anteriores pudemos expor o paradigma poiético da criação. Esse paradigma, na versão proposta por René Passeron, representa a criação como o suprimento do vazio da obra a fazer através de desvios ou retificações rumo à instauração de seu "devant-être". Ele tem, assim, como elemento fundamental a imprevisibilidade do trajeto criativo, e se contrapõe a um outro paradigma que valoriza sobretudo a previsibilidade e o controle do processo instaurativo. Para ilustrar essa contraposição, o próprio René Passeron fizera uma breve referência crítica, que notamos, à diferenciação marxiana (onde a arquitetura aparece como exemplar) entre trabalho humano e trabalho animal: para Marx, diferentemente da abelha, no homem o resultado do trabalho pré-existiria idealmente em seu espírito.

Detenhamo-nos um pouco nessa concepção projetual da criação. Certamente não é Marx que a inventa. Podemos encontrar a lógica inerente a tal paradigma muito antes, já nos antigos filósofos gregos. A Metafísica de Aristóteles, onde o filósofo estabelece determinações com respeito ao fenômeno da produção em geral, já nos dá algumas precisões nesse sentido ${ }^{79}$.

\footnotetext{
79 Segundo George Steiner, a concepção de criação que utiliza a arquitetura como exemplar, ou seja, a concepção de criação como um processo determinado pela prévisão completa da obra, tem origem já em Platão, exatamente na conduta instaurativa do Demiurgo, no Timeu. Com efeito, segundo Steiner, o modelo (eidos), em Platão, antecede a obra e lhe determina, perfeitamente, todos os aspectos essenciais: "El demiurgo del Timeo es un matemático y arquitecto supremo [...] El arquitecto platónico no demuelle ni altera su diseño, pues encarna el ideal de óptima belleza; el cosmos no es en absoluto un work in progress." STEINER, George. Gramáticas de la creación. Madrid: Ediciones Siruela, 2005, pp. 64 e 65. Se, de nossa parte, não nos referimos a Platão e sim a Aristóteles é porque o fundo teológico do primeiro o lança
} 
No livro sétimo, Aristóteles distingue a geração natural - que contém a causa produtiva em si mesma, quer dizer, em outro ser de mesma essência ("um homem vem de outro homem") -, e a produção artificial (técnica), cuja causa está contida em outro ser de outra essência, por exemplo, uma casa construída teve sua forma concebida por um homem, o arquiteto $^{80}$. A principal proposição aristotélica sobre a produção técnica, desenvolvida em boa parte do livro VII da Metafísica, divide-a em dois processos:

Des productions et des mouvements, une étape est appelée conception (noesis), une autre, réalisation (poiesis): ce qui provient du principe et de la forme (eidos) est conception; ce qui naît de la dernière idée de l'esprit est réalisation. ${ }^{81}$

A concepção ou pensamento (noesis) da forma (eidos) é o primeiro e principal momento do processo produtivo; o outro, é a operação realizadora (poiesis), que inscreve essa forma noética em uma matéria (hylê), produzindo-se, assim, uma forma concreta (morphê), como se pode depreender da seguinte passagem:

rendre rond l'airain, ce n'est pas produire la rondeur ou la sphère, c'est produire une autre chose, à savoir cette forme dans quelque chose de différent [le rondeur dans l'airain]. 82

\footnotetext{
em um campo de transcendência - já que o modelo está separado de nossa realidade - afastando-o, assim, radicalmente de nós; em Aristóteles, diferentemente, o processo criativo é, em sua inteireza, imanente, pois a forma (eidos) se encontra não em uma realidade separada, mas na alma do artista. Essa diferença entre Platão e Aristóteles é bem exposta por Enrico Berti, o qual citamos : "La forme est aussi appelée par Aristote 'modèle' (paradeigma), non pas transcendant, comme pour Platon, mais existant dans la chose et dans l'esprit de l'artiste, donc complètement différent de l'Idée séparée de Platon" (BERTI, Enrico. Philosophie de la forme. Eidos, idea, morphé dans la philosophie grecque des origines à Aristote. Louvain : Peeters, 2003).

80 Métaphysique. Traduction de Jean Tricot. Paris : Vrin, 1986, 1032a. Ver também a tradução de Lucas Angioni: ARISTÓTELES, Metafísica, Livros VII-VIII. Campinas: IFCH/Unicamp, 2001.

${ }^{81}$ Métaphysique. Tradução de Jean Tricot, op. cit., 1032b 15-18.

82 Idem, ibidem, 1033a 33-34.
} 
Todo o processo que vai do eidos noético à morphé hilética, da concepção ao produto final, deve ocorrer acompanhada de uma recta ratio factibilium $^{83}$, reta determinação da obra a fazer, como afirma Aristóteles na Ética a Nicômacos4, de tal maneira que a morphé materializada seja o correspondente do eidos concebido ${ }^{85}$. O comentário de J. M. Le Blond é, nesse sentido, esclarecedor pois difere nitidamente a concepção (noesis) e a realização (poiesis) como etapas temporal e hierarquicamente diferentes ao afirmar que a primeira antecipa e rege o ato realizativo:

La démarche essentielle d'Aristote, dans cette étude de la production artificielle, consiste à distinguer deux étapes, l'étape mentale de la noesis, et l'étape de réalisation extérieure, la poiesis. - L'étape mentale commande tout le reste: le médecin qui cherche à guérir un malade doit en effet avoir présente à l'esprit l'idée de la santé qu'il veut rétablir, il doit s'en détailler les conditions précises, par exemple, «l'équilibre», et remonter à l'élement requis pour cet équilibre, la chaleur. De là, il s'efforce de passer aux démarches immédiatement réalisables, la friction, qui sont capables de produire la chaleur et, par là, d'assurer l'équilibre et de rendre la santé. ${ }^{86}$

O comentador refere o exemplo da medicina, mas é notável que Aristóteles faça também menção sistematicamente à arquitetura. Isso

${ }^{83}$ Tal expressão consagrou-se na filosofia escolástica-aristotélica, « Recta ratio factibilium, disons, pour essayer de rendre en français cette définition aristotélicienne et scolastique, que l'art est la droite détermination des oeuvres à faire " MARITAIN, Jacques, Art et scolastique, Paris, Desclée De Brouwer, 1965, p. 18. No agir trata-se de uma recta ratio agibilium ("droite détermination des actes à poser »), e na ciência de uma recta ratio speculabilium («droite détermination des objets de spéculation »), idem, p. 184

84 «La technique est un état accompagné de rasion vraie (meta logon) qui porte à la production » (1140a 10). La sagacité est un état vrai, accompagné de raison, qui porte à l'action quand sont en jeu les choses bonnes ou mauvaises pour l'homme. (1140b 5).

85 Confira-se o comentário de Heidegger : «L'aspect, eidos, est déjà vu au préalable, et certes pas seulement globalemente et en général, mais précisément dans ce à quoi il en retourne à la fin, lorsqu'il doit être par-fait (voll-endet) et fini. Avec l'eidos de l'ergon son être-parvenu-à-la-fin est d'avance anticipé, c'est-à-dire les fins qui le circonscrivent. L'eidos de l'ergon est telos. » (p. 141). Ou ainda : "l'eidos devient, dan l'apeiron limité (de l'hylê), la morphé de cette hylé. » HEIDEGGER, Martin, Aristote, Métaphysique théta 1-3, Paris : Gallimard, 1991, p. 142.

${ }^{86}$ Le Blond, J. M. Logique et méthode chez Aristote. Paris : Vrin, 1970, p. 334. 
nos interessa particularmente, pois a arquitetura é a imagem mais utilizada pela crítica literária para caracterizar a conduta criativa de João Cabral. A concepção de arquitetura em jogo nessa crítica não difere do paradigma aristotélico de produção, que podemos nomear de eidético, já que, como já pudemos observar, não somente nos textos do filosófo grego, mas também nos textos de seus comentadores, como o de Le Blond, citado logo acima, e o de Heidegger, citado na nota 85, é o eidos pré-determinado que comanda o processo produtivo, quando ocorre a realização desse eidos em uma matéria (hylê). De fato, a técnica arquitetônica exemplifica com perfeição o processo produtivo eidético, segundo Aristóteles. Citemos a Metafísica:

l'art [...] de l'architecte [est] le visage (eidos) de la maison, et cette présence qui ne comporte pas de matière est ce que j'appelle l'être en fin de compte ${ }^{87}$.

A essência da técnica produtiva em Aristóteles, exemplificada, pela arquitetura, implica a existência, na alma do artista, do aspecto completo (eidos) da obra a ser feita, tal qual uma "forma-projeto", uma intenção que representa antecipadamente o ergon, se considerarmos, também, o seguinte comentário de Giulia Sissa:

[Il y a une] forme-projet qui se trouve dans l'esprit de l'artisan et à partir de laquelle celui fabrique un objet determiné en sachant ce qu'il fait. $[\ldots]$

C'est donc l'intention, plus précisément la représentation anticipée de l'objet à achever, qui donne un sens à l'activité technique et qui permet de la définiri ${ }^{88}$.

87 Tradução de Bernard Sichère, ARISTÓTELES. Métaphysique. Livres Z à N. Nouvelle traduction du grec ancien par Bernard Sichère. Paris : Pocket, 2010, 1032b. Confira-se a tradução de Tricot: "l'art de bâtir [est] la forme de la maison, et quand je parle de substance sans matière j' entends par là la quiddité ".

88 SISSA, Giulia. La génération automatique. L'animal dans l'antiquité. CASSIN, B. et LABARRIÈRE, J. -L. (org.). Paris : Vrin, 1997, p. 99. A autora ainda comenta de forma esclarecedora a diferença entre medicina e arquitetura com respeito à matéria 
A forma (eidos), concebida pelo artista, permaneceria essencialmente imutável no processo de produção, cuja finalidade é a realização (não a transformação) de tal forma. Esse paradigma eidético, essa definição aristotélica da produção como realização, numa matéria, de uma forma pré-concebida, difere completamente da teoria da criação proposta pela poiética. Provam-no as objeções de René Passeron à "poiética do projeto", que, segundo o autor, levaria à ilusória previsibilidade da obra a ser feita, contrapondo-lhe uma "poiética do trajeto", onde o aspecto final da obra é ignorado, sendo por isso mesmo que o artista a instaura.

Expostos ambos os paradigmas, restará saber se o pensamento cabralino da criação se coaduna com o modelo eidético, ou arquitetônico, no qual a criação é concebida como um processo completamente controlado e pré-visto, ou se, diferentemente, participa do modelo poiético, que inclui a imprevisibilidade e a instabilidade na essência da factividade artística.

intrínseca a cada uma dessas artes. A matéria do médico, onde ele imprime o eidos da saúde, é movente, qual seja, o corpo do doente; na arquitetura, trata-se de uma matéria que não se move, pedras e madeiras. Essa diferença mostra que a produção da saúde pode acontecer por uma geração automática, puramente ao acaso, sem a presença de um médico. Uma casa, porém, não pode se produzir espontaneamente, visto que pedras e madeiras não têm uma dynamis própria (idem, ibidem). 


\section{Capítulo 2. A crítica genética como estudo da gênese da obra de arte literária através dos manuscritos}

\section{1. O manuscrito literário como objeto da crítica genética}

$\mathrm{Na}$ parte anterior mostramos como a poiética distingue a conduta criativa enquanto objeto científico autônomo, fornece métodos para a sua compreensão e descrição, bem como propõe, dela, uma estrutura geral. Afirmando mais as diferenças que as relações de continuidade entre criação, obra feita e recepção, a poiética reduz a primeira à relação do artifex com o opus em processo, relação que acontece no "puro presente" (Thierry Lenain) ${ }^{89}$ da instauração da obra. Tal relação entre sujeito criador e "oeuvre en train" é descrita em termos de desvio, retificação, imprevisibilidade, trajeto, conceitos que distanciam a poiética do paradigma eidético da produção, que, por sua vez, descreve o processo de instauração como a pré-visão completa da forma final da obra e sua realização controlada em uma matéria.

Nesta parte, mostraremos como a crítica genética também fornece instrumentos epistemológicos para o estudo da criação (e em particular, da criação literária), mas de outra maneira. Essa outra

89 LENAIN, Thierry. Le savoir historique comme paramètre objectif de la création artistique contemporaine, art. cit., p. 27 
maneira diz respeito a certa diferença metodológica que existe entre a crítica genética e a poiética. A poiética - e desde Paul Valéry - está, sobretudo, calcada na observação que artistas-filósofos, ou artistas pesquisadores, fizeram de seu próprio trabalho criativo, no conhecimento "íntimo" do processo de criação. A crítica genética, por seu turno, é concebida por linguistas que "observam" a conduta criativa de forma indireta, quer dizer, através da análise dos traços materias da gênese da obra, que, no caso da literatura, são os manuscritos dos escritores ${ }^{90}$.

Na verdade, o objeto da crítica genética não é exatemente os manuscritos de textos literários, mas o que Jean Bellemin-Noël, pela primeira vez, chamou de "avant-texte" (prototexto ou pré-texto), assim definindo-os:

[L'avant-texte c'est] l'ensemble constitué par les brouillons, les manuscrits, les épreuves, les "variantes", vu sous l'angle de ce qui précède matériellement un ouvrage quand celui-ci est traité comme un texte, et qui peut faire système avec lui. ${ }^{91}$

Os prototextos são, portanto, todo documento material que antecede um texto, sendo a ele ligado na medida em que é constituinte de seu processo de preparação. O termo, e sua definição, tendo permanecido canônicos, não ficaram isentos de críticas. Almuth Grésillon, por exemplo, vê aí uma excessiva presença da ideia de texto, o que poderia levar a um erro de determinação do objeto próprio da gênese textual. Este, segundo Grésillon, não é o resultado do percurso genético, mas o processo mesmo de enunciação escrita que leva à constituição de sentido e estruturas textuais. Nas palavras da autora:

90 Quando discutirmos, mais detalhadamente, as relações entre poiética e crítica genética no capítulo seguinte desta parte, veremos que ambas as disciplinas, apesar da diferença de método, não devem se excluir.

${ }^{91}$ BELLAMIN-NOËL, Jean. Le texte et l'avant-texte. Paris: Larousse, 1972, p. 15. 
Une de plus grandes difficultés de la recherche génétique consiste à faire compreendre que sa visée ultime n'est pas le texte, mais l'écriture, entendue comme avènement et événement, comme processus d'énonciation écrite. Or, "avant-texte", tout comme les autres composés, nous ramène irrémédiablement à la notion de "texte". Mieux vaudrait alors peut-être, sinon y renoncer, du moins en faire un usage moderé, et en connaissance de cause ${ }^{92}$.

Preocupada, portanto, em esclarecer que a crítica genética visa a escrita em seu devir produtivo, e não em sua imutabilidade de texto acabado, Almuth Grésillon propõe o uso do termo “dossier génétique" (dossiê genético) como substituto de "avant-textes" (prototextos ou prétextos), pois o primeiro inclui documentos pertencentes a um processo de produção que não necessariamente chegou a um fim, à fixidez da obra, a um texto publicado ${ }^{93}$.

Independentemente, porém, da terminologia, acentuemos apenas isto, que a finalidade última da gênese textual não é interpretar produtos textuais, mas as operações enunciativas de sua instauração, cujos vestígios encontramos nos documentos genéticos. Assim procedendo, a gênese textual se distingue de outras abordagens que também têm como objeto de análise os manuscritos literários, como, por exemplo, a "variantística" e as abordagens psicologizantes da criação literária. É o que se pode ler na seguinte passagem de Almuth Grésillon, que estabelece o estatuto científico do manuscrito, considerado geneticamente, distinguindo a perspectiva genética da filológica e da psicológica:

Au lieu d'être um simple outil pour l'établissement du texte, au lieu d'illustrer, comme dans certaines analyses et enquêtes littéraires du début du XXe siècle, les voies mystérieuses de la psychologie du sujet créateur, le manuscrit devenait de plus en plus un objet scientifique

92 GRÉSILLON, Almuht. Élements de critique génétique, op. cit., p. 109.

93 Idem, ibidem. 
permettant de reconstruire le étapes successives de la genèse du texte et les mécanismes qui soustendent sa production ${ }^{94}$.

O crítico genético, portanto, recusa-se a ler, por meio dos prototextos, o texto "correto", como fazem as pesquisas filológicas das variantes textuais, e também recusa toda abordagem que busca descrever as leis do "trabalho mental" do escritor"95. A tarefa do crítico genético é diferente e pode ser resumida em dois tópicos:

1) "reconstruir as etapas da gênese", isto é, lançar hipóteses sobre a cronologia e o sentido do percurso da produção escrita, através da análise do suporte, dos intrumentos de escrita e do traçado do autor, o que permite estabelecer a correta relação de sucessividade entre os diversos estados do texto (se tal versão é posterior a uma outra, se tal reformulação precede esta outra etc.);

2) reconstruir os "mecanismos subjacentes" à produção textual, ou seja, remontar à operações sistemáticas da escrita, quais sejam acrescer, suprimir, substituir, permutar - e a partir daí lançar conjecturas sobre o tipo de conduta criativa pela qual o scriptor trabalha o material linguístico ${ }^{96}$.

As duas tarefas descritas acima, no entanto, somente são possíveis através da leitura e da interpretação dos vestígios manuscritos. E tal leitura e interpretação começa necessariamente pelo trabalho de decifração e transcrição dos traços observados nos fólios dos dossiês genéticos, sobre o que falaremos a seguir.

${ }^{94}$ Grésillon, Almuth, Mise en oeuvre, Itinéraires génétiques. Paris : CNRS Éditions, 2008, p. 20

95 Para maiores detalhes sobre a diferença entre a crítica genética, a "variantística" e o psicologismo crítico ver HAY, Louis. A literatura dos escritores. Questões de crítica genética. Belo Horizonte: Editora UFMG, 2007, pp. 114 - 117.

${ }_{96}$ Ver também GRÉSILLON, Almuth. Élements de critique génétique, op. cit., p. 15. 


\section{2. Operações de produção textual e métodos de transcrição dos manuscritos}

A rasura é o principal fenômeno observado em um manuscrito com interesse genético - através do qual seja possível apreender algo do percurso da atividade de composição -, porque é o principal traço da transformação de um texto. A rasura é o traço material da operação de modificação discursiva. E mesmo um manuscrito sem rasuras visíveis terá interesse genético se for a reformulação de um texto anterior, o que, de certa forma, configura uma rasura, já que se opera, assim, a substituição de um texto por outro. João Cabral, como veremos na terceira parte desta tese, quando analisarmos seus manuscritos, é um autor que rasura. Sua página, para usar uma metáfora sua, é, muitas vezes, "suja" 97, coberta de riscos que apagam o que foi escrito, fazendo recomeçar a escrita. Suas rasuras instauram tanto modificações substanciais, quanto provocam reorientações locais. Uma descrição precisa do ato de rasurar é, portanto, fundamental para a compreensão do fazer cabralino.

A rasura tem três formas possíveis, segundo Almuth Grésillon:

La première immédiatement visible et permettant en général au lecteur de restituer l'écrit raturé, c'est le trait de biffure ou d'autres formes signifiant annulation: hachures, quadrillages. La seconde, aussi immédiatement visible, mais ne permettant de restituer l'écrit primitif :

\footnotetext{
97 O fazer como algo "sujo" é objeto de vários poemas de Cabral, como, por exemplo, "Debruçado sobre os cadernos de Paul Valéry", do livro Agrestes (1985). Nesse poema, Cabral afirma que Paul Valéry, em seus Cahiers, "sem nenhum medo, deu-se ao luxo/ de mostrar que o fazer é sujo" (Obra completa, op. cit., p. 560). Encontramos uma imagem semelhante nos manuscritos de um poema que Cabral escreveu sobre Charles Baudelaire e que foi interrompido (Pasta Pi. A Charles Baudelaire, no arquivo pessoal do escritor depositado da Fundação Casa de Rui Barbosa): “Talvez diante da folha em branco/te olhava branco esse inimigo/que o homem leva no mais fundo/e o julga com o olhar mais frio./Ele te levava a sujá-la,/a enodoá-la, até a cuspi-la,/além do então tolerável."
} 
le pâté d'encre couvrant l'unité écrite d'une tache noire. La troisième, permettant l'accès aux unités raturées, mais immatérielle en quelque sorte, en tout cas non visible au premier coup d'œil, consiste en des réécritures successives, souvent sur des folios différents, sans que les versions « depassées » soient marquées comme caduques. 98

Das três formas de rasura acima descritas por Grésillon - a rasura visível sem apagamento da forma rasurada, a rasura também visível, mas que apaga a forma rasurada, e a rasura invisível encontramos todas nos manuscritos dos poemas de Cabral ${ }^{99}$. Mas dessas três, muito mais frequente é a primeira, pois o traço de risco, em Cabral, permite, quase sempre, a leitura da unidade rasurada.

Almuth Grésillon, além de distinguir as formas de rasura, distingue suas três funções nos seguintes termos:

[...] la rature ne donne pas nécessairement lieu à réecriture, à la substitution. Ce n'est qu'une de ses fonctions, qui sont au nombre de trois. Les deux autres servent soit à déplacer, soit à suprimmer définitivement. 100

É preciso dizer que essas três operações - substituição, supressão e deslocamento - constituem todas as funções de rasura, mas não correspondem a todas as operações de escrita, pois há uma quarta ainda, e que completa o quadro, qual seja, a operação de acréscimo. Ela não é exatamente uma rasura na medida em que esta pressupõe alguma forma anterior que, depois de apagada, deixa de existir, seja ou não para dar lugar a outra. O acréscimo, por sua vez, não implica o apagamento de um texto anterior. Ao contrário, seu efeito é a expansão de tal texto, que assim é transformado - por vezes completamente. No

\footnotetext{
98 GRÉSILLON, Almuth. Élements de critique génétique, op. cit., p. 67.

99 O terceiro tipo, em Cabral, ocorre sempre que há uma diferença entre o último estado de um manuscrito e a versão publicada, sem que haja traço genético dessa diferença.

${ }^{100}$ GRÉSILLON, Almuth. Élements de critique génétique, op. cit., p. 69.
} 
terceiro capítulo da última parte deste trabalho teremos a ocasião, analisando os prototextos de Cabral, de determinar o grau de modificação efetuado pela operação de acréscimo; muito embora Cabral seja considerado um poeta do "menos", do "corte", há exemplos de manuscritos onde ele expande um texto já passado a limpo por meio de "enxertos", segundo um termo do próprio poeta.

Almuth Grésillon e Jean-Louis Lebrave ${ }^{101}$ propõem uma notação para as quatro operações de escrita, substituição, acréscimo, surpressão e permutação, subsumindo-as a processos substitutivos, a qual reproduzimos a seguir:

a substituição é representada como " $\mathrm{x} \rightarrow \mathrm{y}$ " (a forma y substitui $\mathrm{x}$ );

o acréscimo como “ $\rightarrow \mathrm{X}$ ” (a variável zero é substituída pela forma $\mathrm{x}$ );

a supressão como " $\mathrm{x} \rightarrow \varnothing^{\prime \prime}$ (a forma $\mathrm{x}$ dá lugar à variável zero);

a permutação ou deslocamento como "abcd $\rightarrow$ bcda" (a forma abcd substitui a forma $b c d a)$.

A operação de substituição, como se vê, generaliza-se, na medida em que está na base de todas as outras operações, e mostra sua natureza orientada, quer dizer, sem reversibilidade possível: x substitui y e não o contrário.

O crítico genético decifra e transcreve os traços dessas quatro operações legíveis nos prototextos a fim de facilitar sua própria leitura e interpretação e a dos outros leitores. Dois são os principais métodos de transcrição dos manuscritos ${ }^{102}$ :

101 GRÉSSILLON, Almuth et LEBRAVE, Jean-Louis, Linguistique et génétique des textes: un décalogue. Publicado em 23 de março de 2009. Disponível em: http://www.item.ens.fr/index.php?id=384099.

$102 \mathrm{O}$ dois métodos de transcrição encontram-se expostos em GRÉSILLON, Almuth. Élements de critique génétique, op. cit. pp. 121-131. 
1. o método linear que transpõe, segundo a definição de Almuth Grésillon, "la dimension paradigmatique des réécritures au fil syntagmatique de la ligne"103. Ou seja, nesse caso, não há a representação da disposição dos traços conforme sua localização no fólio. Mas para suprir a ausência de uma representação topográfica das variantes, algumas transcrições lineares utililizam um sofisticado código tipográfico que indica onde se localizam, no fólio, as reformulações ${ }^{104}$. Usaremos esse tipo de transcrição nesta tese somente nas exemplificações simplificadas de algumas passagens manuscritas, utilizando apenas os seguintes sinais, conforme o código de transcrição proposto por Pierre-Marc de Biasi105, adaptando-o para os manuscritos de João Cabral:

<> quando se tratar de uma substituição ou acréscimo na entrelinha (supra-linear e infra-linear);

/ / quando se tratar de uma supressão;

$[<>]$ quando se tratar de uma substituição ou acréscimo depois suprimido;

$<<>>$ quando se tratar de uma substituição ou acréscimo feito na margem;

(?) quando se tratar de uma transcrição provável, mas hipotética;

103 GRÉSSILLON, Almuth, Élements de critique génétique, op. cit., p. 126.

104 Para maiores detalhes sobre esse tipo de transcrição (e as formas mistas), com reproduções fotográficas, ver idem, ibidem, pp. 126-129.

105 Código proposto em sua transcrição do conto de Gustave Flaubert Saint Julien $l^{\prime}$ Hospitalier (BNF, nafr. 23663, t. II, f $\mathrm{f}^{\circ}$ 492). 
(ileg.) quando se tratar de uma palavra ou grupo de palavras ilegíveis.

Exemplo:

/ a não ser a/ <com exceção da> flor eterna ${ }^{106}$

\section{Outro exemplo:}

Não a alma, muito embora

dentro da concha motora

$<<$ Pois a alma que ele leva se arrasta por paus e pedras $>>107$

2. o método diplomático de transcrição, aqui utilizado nas tanscrições completas dos documentos, pretende reproduzir a disposição topográfica dos traços manuscritos sem pretender, no entanto, uma exatidão fotográfica108. Na transcrição diplomática, adaptada aos manuscritos de João Cabral:

- os acréscimos e substituições interlineares e marginais são reproduzidos no lugar onde aparecem. São utilizados caracteres menores para a sua reprodução . Exemplo:

Embora comum, esse amarelo de homem

prende a vista, mesmo a nativa

ainda hoje espanta ali quem 0 avista:109

- as palavras riscadas são reproduzidas sob um risco (ver exemplo anterior).

106 Manuscrito do poema "Velório de um comendador", pasta Pi. Serial, fo 43. 107 Manuscrito do poema "O automobilista infundioso", pasta Pi. Serial, $\mathrm{f}^{\mathrm{o}} 30$.

108 Para esta definição e outras precisões com respeito à transcrição diplomática, consultamos o protocolo utilizado pela equipe do ITEM (Institut de textes et manuscrits modernes) responsável pela transcrição dos "cahiers" 1 a 75 de Marcel Proust depositados na Bibliothèque Nationale de France (BNF). O protocolo nos foi concedido durante uma oficina de transcrição oferecida pela equipe na École Normale Supérieur em maio de 2010, da qual participamos.

109 Manuscrito do poema "Os reinos do amarelo", pasta Pi. A educação pela pedra. $\mathrm{f}^{\circ} 24$. 
- quando uma estrofe é riscada com vários ou um só traço, estes são reproduzidos em sua forma esquemática. Exemplo:

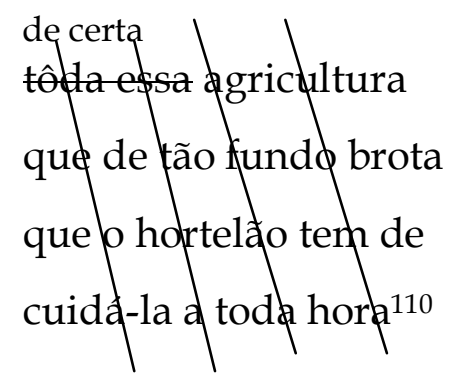

- qualquer outro traço utilizado pelo autor (por exemplo, algum que liga uma passagem a uma nota metalinguística) é, na medida do possível, recuperado. Veja-se a transcrição do poema "Catar feijão", no segundo capítulo da terceira parte;

- as mudanças de instrumentos (canetas de cores diferentes, lápis) e outras especificidade materiais são assinaladas em notas de rodapé;

- também em nota damos a localização do manuscrito no arquivo do poeta, segundo a classificação da Fundação Casa de Rui Barbosa;

- utilizamos o sinal (?) quando se tratar de uma transcrição provável, mas hipotética;

- utilizamos (ileg.) quando se tratar de uma palavra ou grupo de palavras ilegíveis.

110 Manuscrito do poema "Generaciones y semblanzas", pasta Pi. Serial. fo 17. 


\title{
2. 3. Método linguístico de interpretação do manuscrito: o fenômeno da paráfrase
}

\author{
Como afirma Almuth Grésillon, "tout manuscrit est une terre \\ d'élection pour les amoureux de la langue en acte"111. O grifo da autora \\ não é por acaso: um manuscrito não é exatamente um texto ${ }^{112}$, quer \\ dizer, não se trata do produto final e acabado de uma atividade, mas a \\ expressão mesma dessa atividade de produção. Assim, para a autora, \\ uma compreensão correta do manuscrito somente é possível se nos \\ distanciamos do princípio saussuriano de fixidez da língua concebida \\ como um sistema de signos, e procedemos conforme uma teoria da \\ enunciação, pois somente esta pensa dinamicamente a linguagem como
}

\footnotetext{
111 Élements de critique génétique, op. cit., p. 147

112 Tanto Louis Hay quanto Jean-Louis Lebrave já levantaram a dificuldade de se definir o manuscrito a partir de critérios textuais. Nota o primeiro que, desde a "Idade Média monástica" até o estruturalismo, independentemente das exigências religiosas de um lado, e científicas de outro, a definição de um texto pauta-se pelos critérios de "pureza e formalidade". Assim, por exemplo, na teoria estruturalista, um texto é pensado como "um produto acabado", "incomensurável a tudo o que não é ele mesmo" (p. 40). Ora, o manuscrito é a imagem do inacabamento mesmo, e, diferentemente da visão textual do estruturalismo, não está "fechado", tendo sempre uma relação, não intertextual, mas genética, com outros prototextos ou textos. (HAY, Louis. A literatura dos escritores, op. cit., pp. 40 e 44). Jean-Louis Lebrave, por sua vez, debruça-se principalmente sobre os manuscritos interrompidos, onde a ideia de um sentido completo é impossível, para mostrar o quão a teoria tradicional do texto é insatisfatória para o tratamento conceitual dos documentos genéticos. Essa teoria, segundo Lebrave, tem critérios sobretudo delimitativos; por exemplo, um texto deveria ter uma "completude sintática". O caso de um fragmento textual genético que acaba no meio de uma palavra corresponderia, assim, a uma "sorte d'aberration dans les faits de langue en générale". Mas, segundo o autor, "la notion de textuel génétique n'implique aucune frontière.". Somente uma concepção "partitiva" do texto, diz Lebrave, poderia dar conta da fragmentação genética, ou seja, na medida em que consideramos o manuscrito não como um texto, mas como um material textual: "[la] notion partitive de texte s'applique particulièrement bien aux données génétiques [...]. Surtout lorsqu'elles ont une forme fragmentaire, ils ne sont pas un texte, ni même les fragments d'un texte, et pourtant il est légitime de les considérer comme des fragments textuels, comme $d u$ texte » (LEBRAVE, Jean-Louis, L'écriture interrompue : quelques problèmes théoriques «. In: Le manuscrit inachevé. Écriture, création, communication/ed. por HAY, Louis. Paris : Éditions du CNRS, 1986, pp. 141-143).
} 
uma série de operações de construção do sentido, da qual o manuscrito é uma ilustração:

La théorie énonciative permet d'appréhender le fouillis graphique des brouillons en termes d'opérations langagières et d'accéder ainsi à des noyaux significatifs de l'écriture. ${ }^{113}$

Dentre essas operações linguageiras, uma há que nos interessa particularmente aqui, na medida em que revela o mecanismo por excelência da escrita cabralina: a paráfrase. A paráfrase, na verdade, segundo Almuth Grésillon, é uma operação necessária em todo processo de criação textual, como se pode ler nesta passagem da autora:

Ce que les dossiers génétiques montrent en plus, et sans doute mieux que les modèles abstraits ou les études sur l'oral, c'est que toute constitution du sens, loin dêtre préétablie passe nécessairement par ces deux opérations [paraphrase et ambigüité]. ${ }^{114}$

Porém, é preciso perguntar-se o que se entende teoricamente por operação parafrásica. A paráfrase é definida, de forma geral, como reformulação discursiva, ou, segundo as definições de Caterine Fuchs, como "la reformulation, dans une situation discursive donnée, d'un texte-source de départ"115, ou ainda "la reformulation d'une séquence en termes d'une autre"116. Assim, o conceito de paráfrase é perfeitamente pertinente para a interpretação dos manuscritos na medida em que estes são sobretudo traços da operação de substiuição de formas linguísticas por outras no processo de elaboração textual. As

${ }_{113}$ GRÉSILLON, Almuth. Élements de critique génétique, op. cit, p. 151.

114 GRÉSILLON, Almuth, LEBRAVE, Jean-Louis. Paraphrases et ambiguités dans la production du texte littéraire. In: L'ambigüité et la paraphrase. Opérations linguistiques, processus cognitifs, traitements automatisés, op. cit., p 128.

115 FUCHS, Catherine. Paraphrase et énonciation. Paris: Ophrys, 1994, p. 3.

116 Idem. Élements pour une approche énonciative de la paraphrase dans les brouillons de manuscrits. In : La genêse du texte : les modèles linguistiques/ed. por HAY, Louis. Paris : Éditions du CNRS, 1987, p. 86. 
quatro operações de base da escrita - acréscimo, supressão, substituição e permutação (ou deslocamento) - são, aliás, como mostra Catherine Fuchs, as mesmas operações de base que utilizamos para descrever a transformação de uma frase $\mathrm{X}$ em uma frase $\mathrm{Y}$, em termos de reorganização formal da primeira unidade de sentido ${ }^{117}$.

A definição de paráfrase como reformulação discursiva, dada acima, é geralmente aceitável. Mas um estudo mais aprofundado da paráfrase mostra que há ao menos duas concepções diversas dessa operação.

A primeira concepção de paráfrase a define a partir da noção de equivalência. Ou seja, um texto-fonte $\mathrm{T}$ e um texto-alvo $\mathrm{T}^{\prime}$ são equivalentes na medida em que o texto de partida $\mathrm{T}$ e o texto produzido pela reformulação $\mathrm{T}^{\prime}$ têm o mesmo conteúdo $\mathrm{C}$, ou remetem ao mesmo núcleo de sentido ${ }^{118}$. Assim, pode-se dizer que a paráfrase, enquanto produção de sentido através da substituição de um enunciado por outro equivalente, não implica uma transformação do conteúdo do texto-fonte, e leva à suposição da existência de uma intenção de significação que permanece invariante e se repete em toda a cadeia parafrásica.

A segunda concepção define a paráfrase a partir da noção de assimetria. $\mathrm{O}$ texto-fonte $\mathrm{T}$ e texto-alvo $\mathrm{T}^{\prime}$ são assimétricos na medida em que o texto-fonte $\mathrm{T}$ tem um conteúdo $\mathrm{C}$ e o texto reformulado $\mathrm{T}^{\prime}$ tem um conteúdo $C^{\prime}$. Pode-se dizer que a concepção da paráfrase como produção de uma cadeia textual assimétrica implica a transformação por vezes radical - do conteúdo do texto-fonte, e exclui a existência de

117 FUCHS, Catherine. Paraphrase et énonciation, op. cit., p. 59-60.

118 Idem, ibidem, p. 26. 
uma intenção de significação invariante, pois a intenção deviria outra ou somente se estabeleceria durante o processo reformulativo. ${ }^{119}$

Para a apresentação das duas concepções, nos referiremos a duas teorias distintas. A primeira concepção - paráfrase como relação de equivalência - terá seus pressupostos revelados a partir da teoria linguística de Bernard Pottier. A segunda - paráfrase como relação de assimetria - a partir da teoria proposta por Catherine Fuchs. Apresentaremos também nossa reflexão crítica relativamente a essas duas concepções.

119 Essas duas concepções seriam consequências de duas teorias linguísticas distintas que Jean-Jacques Franckel, de maneira talvez simplista demais, nomeia de teoria "mentalista" e teoria "construtivista". Na primeira, haveria a primazia do pensamento sobre a linguagem, sendo esta a representação de uma intenção que permanece a mesma nas variações enunciativas; na segunda, ao contrário, a linguagem constitui o pensamento, de tal maneira que a intenção se constrói à medida em que ocorrem as reformulações. Nas palavras do autor: "Dans une approche mentaliste, les représentations mentales sont appréhendées comme premières, le langage est considéré comme une mise en forme, une sorte de «traduction » de la pensée. [...] elle donne un statut à ce qu'est «la pensée » indépendamment des représentations qui permettent de l'appréhender, en particulier de cette forme de représentation que constitue le langage. Dans une approche constructiviste, le sens est considéré en tant que déterminé et construit par le matériau verbal qui lui donne corps [...] Cela signifie que les textes et les unités morpho-lexicales agencées qui les constituent ne sont pas considérés comme la traduction d'un sens qui leur préexisterait ou qui existerait indépendamment de ce matériau. [...] Le langage constitue une forme de pensée. (FRANCKEL, Jean-Jacques, "Introduction». In: Langue Française. Le lexique, entre identité et variation, 2002, $\mathrm{n}^{\circ} 133$, p. 4). O autor baseia-se, de forma evidente, na teoria de Antoine Culioli que contrapõe uma linguística preocupada com os ajustes enunciativos a uma que reduz a atividade de significação à "empaquetage codé d'une intention claire et arrêtée" (CULIOLI, Antoine. Préface. La genèse du texte: les modèles linguistiques, op. cit., p. 10.) 


\section{4. Duas concepções de práfrase: Bernard Pottier e Catherine Fuchs}

A última grande síntese publicada por Bernard Pottier de sua teoria linguística (Représentations mentales et catégorisations linguistiques) ${ }^{120}$, tende, como afirma o autor, “à illustrer les mécanismes supposés du monde mental dans lequel se réalise le passage des perceptions élaborées vers les choix sémiologiques"121. Essa passagem do conceitual ao linguístico se dá, em uma perspectiva enunciativa, por meio de dois percursos de constituição do sentido inerentes ao fenômeno de comunicação interpessoal: o percurso enunciativo (onomasiológico), e o percurso interpretativo (semasiológico) ${ }^{122}$. O primeiro percurso é pensado do ponto de vista do emissor e é assim definido pelo linguista:

Le parcours onomasiologique va d'un premier infini réferentiel, complexe et flou, à un second infini séquentiel d'extension

120 POTTIER, Bernard. Représentations mentales et catégorisations linguistiques, Louvain Paris: Editions Peeters, 2000.

${ }^{121}$ Idem, ibidem, p. XV.

122 A distinção desses dois percursos já fôra feita em obras anteriores do linguista, por exemplo, em Semântica geral (Paris: PUF, 1992). Referindo-se a esta obra, Maria Helena Araújo Carreira assim define as duas noções (onomasiologia e semasiologia): “ $\mathrm{O}$ linguista [Bernard Pottier] tende a reconstituir a comunicação no seu duplo percurso, o onomasiológico (o do emissor/enunciador) e o semasiológico (o do receptor/interpretante). $\mathrm{O}$ enunciador parte de um referente (concreto ou abstracto, real ou imaginário), conceptualiza o seu QUERER DIZER, isto é, 'põe em cena' mentalmente e semiotiza (escolha de signos numa dada LN e escolhas sintáticas) essa representação mental, apropriando-se assim das virtualidades da língua para a enunciação do seu discurso, isto é, 'põe em cadeia' os signos. [...] O interpretante, por seu turno, parte do discurso produzido ('texto, oral ou escrito') e, graças ao seu SABER, identifica os elementos discursivos, constrói uma hipótese interpretativa que o leva a compreender a mensagem, a conceptualizar, desligando-se assim dos signos linguísticos [...]. O interpretante pode, em seguida, tornar-se enunciador e o primeiro enunciador interpretante e assim por diante. (CARREIRA, Maria Helena Araújo. Para uma leitura guiada de Sémantique générale, de Bernard Pottier, com adaptações ao português. In: Semântica e discurso. Estudos de portuguesa e comparativa (português/francês). Porto: Porto Editora, 2001, p. 12. 
indéterminée et imprévisible, à travers un mécanisme de réduction (conceptualisation) puis d'extension (discursivisation), autour d'un centre (la compétence de langue), relativement stable à un moment donné de l'énonciation ${ }^{123}$.

Assim, o enunciador, ao construir o sentido onomasiologicamente, parte de um mundo referencial, seleciona, entre esses diversos dados empíricos os que correspondem à sua intenção de comunicar, conceptualizando-os, e, por fim, formaliza ou semiotiza sua representação mental "en fonction des contraintes de la langue et des pressions culturelles". ${ }^{124}$

O segundo percurso, o semasiológico, que descreve o processo comunicativo do ponto de vista do receptor ou interpretante, é, por sua vez, definido pelo linguista nos seguintes termos:

Le point de départ est une séquence textuelle qui est saisie par l'interprétant. Celui-ci utilise ses connaissances de langue pour repérer, au long de la séquence, les tranches de discours susceptibles de lui livrer une information qui contribue à sa compréhension, laquelle se construit peu à peu, par additions entraînant constamment des réinterprétations.

Se no percurso onomasiológico se parte do mundo referencial e depois se passa pela conceptualização até chegar a um texto, no percurso semasiológico o interpretante parte da indentificação de um texto (graças ao conhecimento da língua), passa pela sua compreensão (graças a um conjunto de saberes que possui), até chegar a diversas reações possíveis, inclusive a produção de um novo texto, que porá o primeiro emissor na situação de receptor.

123 POTTIER, Bernard. Représentations mentales et catégorisations linguistiques, op. cit. p. 36.

${ }^{124}$ Idem, ibidem, p. 33. 
É exatamente no processo de semiotização, quer dizer, na passagem do conceptual ao linguístico, em ambos os percursos, que se apresenta o fenômeno de paráfrase ou parasinonímia, na terminologia do autor. Citemos:

Dans le passage du conceptualisé au linguistique, on retiendra deux opérations fondamentales:

- le choix de lexies : la polynomie

- le choix des structures: la polysémiose.

Toutes deux constituent l'essentiel de la sémiotisation ${ }^{125}$

Na operação de polinomia - escolha de lexias -, como nota Pottier, considerando-se que existe o fenômeno de ortonímia, onde a lexia escolhida tem uma relação imediata com o visto e com o mentalmente representado, é possível obter uma série onímica que se desvia de maneira progressiva dessa imediatidade por meio da metonímia, da metáfora e da peronímia. Conforme suas palavras:

On obtient ainsi une série onymique qui s'écarte progressivement de l'immédiateté. La métonymie est conditionnée par la conceptualisation $\mathrm{du}$ réferent, la métaphore s'en libère à travers des associations de plus en plus imprévisibles et la péronymie embrasse toutes les séquences analytiques imaginables ${ }^{126}$.

As diversas formas da série onímica (ortonímia, metonímia, metáfora e peronímia), realizadas como escolhas lexicais para a representação do pensamento em um DITO, guardam uma relação de parasinonímia, ou seja, tem o mesmo ponto de partida conceitual já que se referem à mesma intenção de significação, a um mesmo núcleo de sentido.

Embora Bernard Pottier aqui se interesse sobretudo pelas relações de comunicação interpessoal, o autor não deixará de determinar o

125 Idem, ibidem, pp. $116-117$.

126 Idem, ibidem, p. 117. 
fenômeno de polinomia e de polisemiose, quer dizer, das múltiplas escolhas de lexias e estruturas para a semiotização de uma representação mental, no âmbito da produção textual. É o que fez de fato em um texto intitulado "La paraphrase textuelle dans ses fondements théoriques". Citemo-lo:

Sur le plan intentionnel (niveau conceptuel ou mental), l'auteur veut dire un événement (pris dans son acception la plus large), et il procède à une confrontation avec son savoir (linguistique et encyclopédique) afin de choisir les composantes qui lui paraissent le plus adéquates. Étant ainsi entré en langue naturelle, il va poursuivre l'élaboration d'un message qui sera énoncé. Celui-ci n'étant jamais totalement satisfaisant par rapport à l'intention de départ, l'auteur peut relancer l'opération un nombre indeterminé de fois. On aboutit ainsi à un texte composé de plusieurs redites, toutes différentes entre elles, mais reliées à un même point de départ ${ }^{127}$

O fenômeno da paráfrase corresponde, portanto, à repetição da operação de escolha de lexias e estruturas, durante o processo de elaboração linguística, próprias para a representação linguística do conteúdo intencionado. Uma vez que, como Bernard Pottier por diversas vezes o afirma, as diversas lexias em relação de parasinonímia têm, entre si, um sema comum, o fenômeno parafrásico, conforme modelo do próprio autor, pode ser representado da seguinte maneira ${ }^{128}$ :

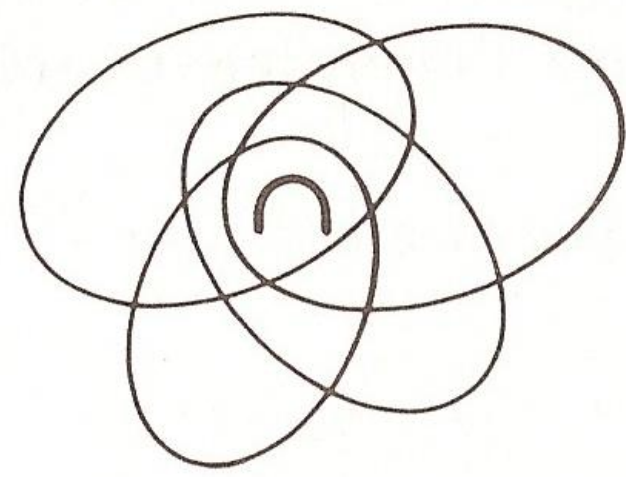

127 POTTIER, Bernard. La paraphrase textuelle dans ses fondements théoriques. Cahiers de linguistique hispanique médiévale, 1990, nº 14-15, p. 37.

${ }^{128} \mathrm{O}$ esquema foi retirado de Sémantique générale, op. cit.. 43. 
O esquema acima mostra inequivocadamente como as diversas construções semióticas em relação parasinonímica ou parafrásica estão ligadas por um mesmo núcleo sêmico. Uma exemplificação desse tipo de relação pode ser retirada dos próprios manuscritos de João Cabral de Melo Neto. No prototexto do poema "O alpendre no canavial"129, temos a seguinte sequência de reformulações, incluindo-se a versão definitiva:

é possível ver como tempo/pode frear sua passada

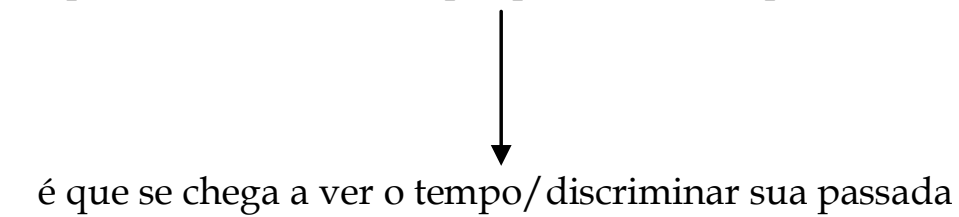

$\downarrow$

é que se chega a ver que o tempo/sabe moderar sua passada.

Apesar de algumas diferenças de modalidade ("pode frear", "sabe moderar") e nocionais (frear = imobilidade; moderar = vagarosidade) ligadas às formas verbais escolhidas pelo poeta, essa sequência tripla de dois versos pode ser vista como um tentativa de representação de um só conceito, o de lentidão do tempo.

Bernard Pottier em outra obra, Théorie et analyse en linguistique 130 propõe um outro esquema de representação da equivalência parasêmica:

\footnotetext{
${ }^{129}$ Pasta Pi. Serial, $\mathrm{f}^{\mathrm{o}} 71$.

130 POTTIER, Bernard.Théorie et analyse en linguistique. Paris : Hachette, 1992. p. 56.
} 


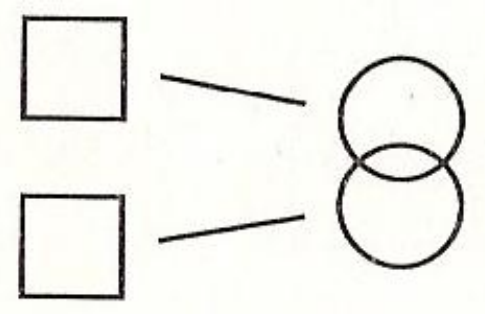

Os quadros acima representam significantes diversos que partilham significados diferentes, porém com o mesmo núcleo de sentido em comum, representado pela intersecção dos círculos. A sequência paráfrasica de João Cabral, citada logo há pouco, pode perfeitamente ser utilizada como uma exemplificação:

\begin{tabular}{|l|}
\hline frear a \\
passada
\end{tabular}

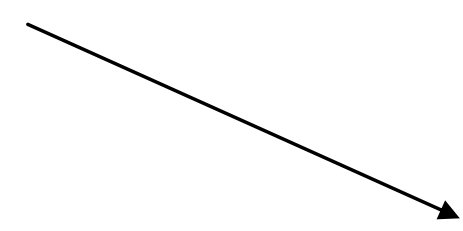

discriminar
a passada

lentidão

moderar a
passada

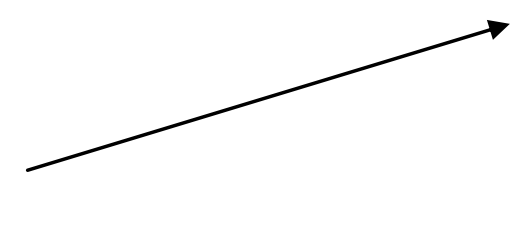

Uma das tarefas do interpretante das sequências parafrásicas, além de identificar a que série onímica (ortonímia, metonímia, 
metáfora, pernonímia) pertencem as diversas reformulações, seria justamente, nas palavras do autor, “re-constituer l'intentionalité du texte"131, ou seja, recuperar o núcleo de sentido comum às diversas séries, pronto a elevar a interpretação a um nível sempre mais alto de abstração. Porém, é preciso atentar para o fato de que Bernard Pottier não esquece a existência de diferenças semânticas entre as várias séries reformulativas, pois afima que cada sequência de paráfrases "répresente un 'plus' sémantique par rapport à une intentionalité" de origem $^{132}$. A identificação desse "plus" semântico, portanto, é também uma das tarefas do intérprete.

A concepção de paráfrase de Bernard Pottier, que valoriza a equivalência na relação parafrásica, sem que ignore as diferenças nela contidas, será criticada por linguistas que, contrariamente, valorizam a assimetria, sem que também, por seu turno, ignorem as semelhanças entre as diversas reformulações. É o teor dessa crítica que veremos a seguir, através da teoria de Catherine Fuchs.

Em seu primeiro livro sobre a paráfrase ${ }^{133}$, Catherine Fuchs se debruça sobre o que ela afirma ser a "contradiction fondamentale" dessa operação:

[La contradiction fondamentale de la paraphrase est] la transformation progressive du «même » (sens identique) en $\mathrm{l}^{\prime}$ " "autre » (sens différent): à redire la «même » chose, on finit par dire « autre » chose - au terme d'un processus continu de déformations négligeables, voire imperceptibles. ${ }^{134}$

Essa contradição intrínseca à operação de paráfrase, transformar progressivamente o "mesmo" em "outro", leva a autora a afirmar a

131 POTTIER, Bernard. La paraphrase textuelle..., art. cit. p. 45.

132 Idem, ibidem, p. 42

${ }^{133}$ FUCHS, Catherine. La paraphrase. Paris: PUF, 1982.

134 Idem, ibidem, p. 49 -50. 
impossibilidade de uma indentidade - considerando esta como uma "synonymie absolue"135 - entre os componentes de uma série reformulativa. Tanto a tese de identidade de sentido, quanto a sua impossibilidade, como nota autora, foram formuladas no âmbito da teoria linguística transformacionista. A identidade seria assimilada à "informação objetiva" contida em cada uma das formas parafrásicas ${ }^{136}$. Mas os críticos desse princípio teórico, por seu turno, rebatem afirmando que "il existe très peu (si même il en existe) de couples de phrases ayant une forme grammaticale différente, et qui [...] aient la même structure sémantique"137. Catherine Fuchs assume tal crítica e renuncia também a caraterizar a paráfrase como relação de identidade semântica. Restaria, assim, uma concepção de reformulação textual que a define como uma relação de equivalência semântica, exposta por Fuchs nos seguintes termos:

Une relation d'équivalence sémantique [est] fondée sur l'existence d'un noyau sémantique commun sur lequel se greffent des différences sémantiques secondaires (cf. les notions de «pseudo -», «quasi- » ou «para-» synonimie, en matière de lexique). Entre deux phrases déclarées paraphrastiques, il y aurait donc à la fois du «pareil » et du «pas pareil»: tout le travail du linguiste consisterait, dans une telle optique, à définir la nature des sémantismes communs et des sémantismes différentiels, et à établir des degrés d'équivalence entre phrases, selon le type et le nombre des élements sémantiques communs à deux paraphrases. ${ }^{138}$

A concepção de paráfrase como relação de equivalência descrita nessa citação por Catherine Fuchs é semelhante à de Bernard Pottier,

${ }^{135}$ FUCHS, Catherine. La paraphrase, op. cit., p. 51.

136 Segundo o propósito de Z. Harris citado por Fuchs : « Les transformées conservent invariant ce que l'on peut interpréter comme le contenu informationnel" ("Cooccurrence and transformation in linguistics structure ", Langage, Baltimore, 1957, citado por FUCHS, Catherine. La paraphrase, op. cit., p. 51.

137 A frase é de T. Shopen, "Logical equivalence is not semantic equivalence". Papers from the $8^{\text {th }}$ regional meeting, Chicago, 1972, citado por FUCHS, Catherine. La paraphrase, op. cit., p. 52.

138 FUCHS, Catherine. La paraphrase, op. cit., p. 53. 
analisada acima. Encontram-se os conceitos de "núcleo semântico comum" e de "diferenças semânticas secundárias" que constituem a relação entre as formas parafrásicas. Mas não é essa, absolutamente, a concepção defendida pela autora. Ao contrário, todo seu segundo livro sobre a questão, Paráfrase e enunciação será dedicado a uma crítica de tal teoria. O conteúdo dessa crítica denuncia o caráter "estático" e "fechado" da ideia de paráfrase como relação de equivalência entre formas linguísticas. Conforme as palavras da autora:

La conception traditionelle de la paraphrase comme relation d'équivalence revient à traiter les familles de paraphrases comme des ensembles de phrases partageant un même "noyau de sens » commun (appelé invariant) sur lequel viennent se greffer des variations mineures. Cette conception statique et fermée des classes d'équivalence peut être symbolisée de la façon suivante :139

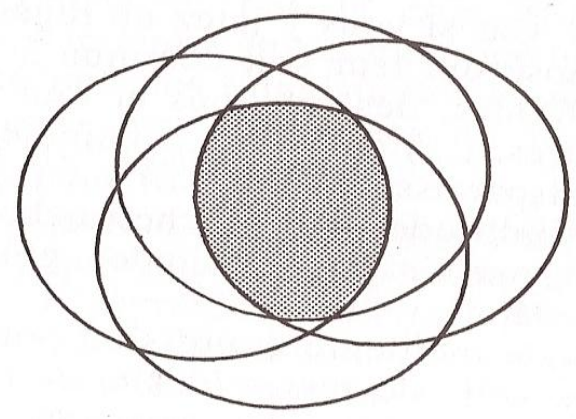

Bem entendido, a concepção de paráfrase como uma relação de equivalência entre séries lexicais seria "estática" e "fechada", na medida em que não haveria mobilidade e abertura do sentido partilhado pelas formas parafrásicas, pois seu núcleo permanece o mesmo em toda cadeia reformulativa, independentemente de certas diferenças semânticas existentes entre elas. Ou seja, o caráter "estático" e "fechado" da teoria da equivalência, deve-se, nos termos da autora, ao

\footnotetext{
${ }^{139}$ A citação acima e o esquema reproduzido encontram-se nas páginas 130 - 131 do livro Paraphrase et énonciation, op. cit. A extrema semelhança da figura acima com o esquema de Bernard Pottier não deixa dúvidas que um dos alvos da crítica de Fuchs é, entre outros, o autor de Sémantique génerale, ainda que a autora afirme haver retirado a figura do livro de G. Kleiber, La semantique du prototype: catégories et sens lexical. Paris: PUF, 1990.
} 
postulado de "estabilidade" e "univocidade" do sentido que permanece invariante na sequência de reformulações. Admitindo um sentido unívoco e estável, a teoria da equivalência parafrásica, segundo Catherine Fuchs:

genère des familles paraphrastiques à partir d'un sens de base que l'on construit pour les besoins de la cause et que l'on postule clair, fixe, unique, déterminé. ${ }^{140}$.

Por outro lado, essa mesma teoria, devido a seu princípio de univocidade e estabilidade do sentido, conforme ainda a autora, postula a existência de valores referenciais constantes, e empobrece, assim, a análise das diferenças entre os diversos semantismos das frases reformuladas. Citemos:

[Cette théorie] décrit les seules variations lexicales et syntaxiques, en ignorant les variations possibles au niveau de l'assignation de valeurs réferentielles (temps, aspect, modalité, personne, etc.) ${ }^{141}$

Por essa concepção «estática » e «fechada », que se interessa sobretudo pelas semelhanças (o sentido invariante) entre as paráfrases, negligenciando execessivamente as diferenças (as distorções semânticas), a autora propõe substituir uma "dynamique de la signification"142. Essa visão dinâmica da reformulação textual leva a pensar as séries paráfrasicas não como sendo ligadas por um "núcleo semântico comum" (equivalência), mas por uma "semelhança de família", segundo a expressão de Ludwig Wittgenstein, citado por Catherine Fuchs ${ }^{143}$. A noção de semelhança de família não postula que haja um semantismo comum entre as diversas paráfrases, mas que

\footnotetext{
140 Paraphrase et énonciation, op. cit., p. 73.

141 Idem, ibidem.

142 "La dynamique de la signification" é justamente o título da segunda parte da obra Paraphrase et énonciation, op. cit., pp. $83-170$.

${ }^{143}$ A autora cita o filósofo austríaco na p. 132 de sua obra referida na nota anterior.
} 
existe, entre elas, todo um "réseau complexe de similitudes", conforme as palavras do filósofo austríaco, similitudes próximas às semelhanças que há entre os membros de uma família: "la conformation, les traits, la couleur des yeux, la démarche, le tempérament, etc." ${ }^{144}$. Os termos e o esquema com que Catherine Fuchs apresenta sua concepção dinâmica da paráfrase são os seguintes:

$\mathrm{Au}$ contraire [de cette conception estatique et fermée] la conception dynamique et ouverte [...] revient à traiter les paraphrases comme ne partageant qu'un "air de famille », c'est-à-dire comme étant reliées par des relations sémantiques locales, de type associatif, construites par le jeu d'interprétation; ce que l'on peut symboliser ainsi (à condition de concevoir ces "patatoïdes" comme des «élastiques» sur lesquels on peut tirer jusqu'à les rendre brusquement disjoints) :145

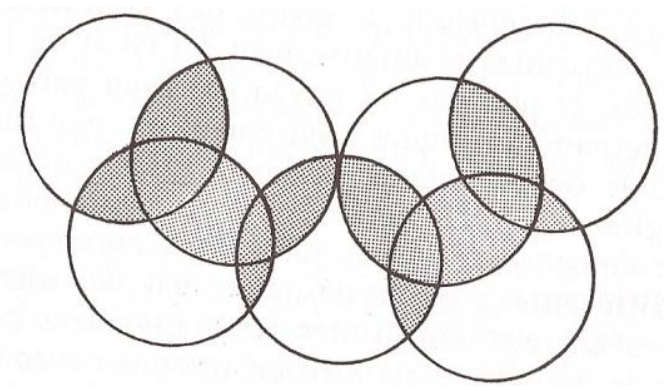

O parentesco como elemento essencial da relação parafrásica reduz as similitudes de sentido entre os membros da cadeia reformulativa a um nível local, e trata as diferenças como principais do ponto de vista da construção de valores semânticos. A noção de parentesco quer, assim, enfraquecer os postulados de base da noção de

144 Citamos o filósofo via Catherine Fuchs. A passagem de Wittgenstein pode ser encontrada na obra Investigações filosóficas (Petrópolis: Vozes, 1994, parágrafos 66 e 67). Citemos a tradução brasileira feita por Marcos G. Montagnoli: “Não posso caracterizar melhor essas semelhanças [entre os jogos de linguagem] do que por meio das palavras "semelhanças familiares"; pois assim se sobrepõem e se entrecruzam as várias semelhanças que existem entre os membros de uma família: estatura, traços fisionômicos, cor dos olhos, andar, temperamento, etc., etc. E eu direi: os 'jogos' formam uma família"

145FUCHS, Catherine. Paraphrarse et énonciation, op. cit., pp. 130-131. 
equivalência: univocidade da significação, valores referenciais constantes e variações semânticas neglicenciáveis ${ }^{146}$. No lugar de tais postulados a teoria do parentesco propõe o de plurivocidade constitutiva proveniente da "plasticité sémantique des marqueurs de référentiation"147. Quer dizer, ao substituir um marcador linguístico por outro na produção de uma relação parafrásica, o enunciador lança mão de operadores diferentes dos quais resultam valores semânticos também diferentes. Assim, essa plasticidade semântica inerente aos marcadores leva a pensar a significação do enunciado, segundo Catherine Fuchs, em termos de "deformabilidade" et de "instabilidade relativa"148. A deformabilidade põe em evidência os limites da equivalência entre os enunciados parafrásicos, indo desde uma deformação aceitável, onde não há grandes diferenças qualitativas entre eles, até a transgressão do que a autora chamou de "limite de distorção" ("seuil de distortion"), onde o enunciado produzido altera radicalmente o enunciado que ele reformula. Nas palavras da autora:

Intuitivement, chacun s'accorde à dire qu'une reformulation $\mathrm{T}^{\prime}$ est une paraphrase admissible d'un T-source lorsqu'elle peut être considérée comme restant dans les limites de la déformabilité acceptable par rapport à $\mathrm{T}$ - quelle que soit l'aune à laquelle on juge cette acceptabilité : c'est-à-dire lorsqu' elle en " étire » en quelque sorte le sens, sans que l'on ait le sentiment qu'un seuil qualitatif est franchi, qui ferait basculer dans un sémantisme consideré comme radicalement autre; j'appellerai ce seuil le seuil de distortion. Inversement, on s'accorde à dire qu'une reformulation $\mathrm{T}^{\prime}$ " altère » $\mathrm{T}$ lorsqu' elle franchit un tel seuil - selon que l'on a de la paraphrase une conception plus ou moins large, on dira dans ce cas que la reformulation est une paraphrase déformante à l'excès, ou bien qu'il s'agit d'une reformulation non paraphrasique. ${ }^{149}$

\footnotetext{
146 Idem, ibidem, p. 172.

147 Idem, ibidem.

148 Idem, ibidem, p. 98.

149 Idem, ibidem, p. 29.
} 
A ideia é que se pode ter entre diversos termos de uma série reformulativa uma diferença semântica tal que, ou ela não pode ser apagada em prol de um núcleo sêmico comum, ou ela simplesmente expressa uma transformação completa do sentido, e é nesse último caso que se ultrapassa o limite de deformabilidade aceitável, o limite de distorção semântica. Tomemos um exemplo retirado dos manuscritos de João Cabral. No prototexto do poema "Catar feijão" (Pasta Pi. A Educação pela pedra 1), os dois versos seguintes:

1) então, cata-se o bom na superfície e joga-se fora o que boia inerte, defunto.

foram substituídos por

2) e como boiam igual o grão bom e o ruim joga-se fora o que boia inerte e defunto.

que por sua vez foram assim reformulados:

3) pois para catar esse feijão, soprar nele, e jogar fora o leve e oco, palha e eco.

$\mathrm{Na}$ passagem de (1) para (2) temos importantes modificações semânticas, como, por exemplo, a substituição da conjunção temporal “então" pela aditiva " $\mathrm{e}$ ", o que transforma a modalidade argumentativa do poema150, além doutras menos notáveis como a supressão do termo "superfície" [da água], em (1) que continua, de certa forma, referenciado em "boiam igual" [na superfície da água] em (2), e o acréscimo de "ruim" em (2) que já era referenciado, in absentia, em (1). A reformulação, apesar de tais diferenças, pode, no entanto, ser

150 Para uma análise mais detalhada dessas reformulações vide o $2^{\circ}$ capítulo da $3^{\mathrm{a}}$ parte desta tese. 
considerada dentro de uma "deformabilidade aceitável", pois mantémse um parentesco forte entre os dois enunciados: descreve-se o mesmo procedimento: o catar, entre os grãos que boiam, os bons, e o jogar fora os ruins ("inertes e defuntos"). Mas entre (2) e (3) não há como não admitir que uma certa distorção de sentido é instaurada, pois não se trata agora de catar o grão bom que boia, mas de soprar no grão, jogando fora a "palha", o que é um procedimento diverso. Dir-se-ia, no entanto, que as formas (2) e (3) guardam ainda, no fundo, certa similitude, pois descrevem o procedimento de separação do material linguístico propício à composição poética.

Um outro exemplo, porém, mostra como a reformulação em Cabral produz diferenças semânticas mais fortes. Tomando em conta o manuscrito do poema "Escritos com o corpo"151, bem como a versão publicada desse poema, temos a seguinte série reformulativa:

1) que é corpo mais alma mais gesto/três dimensões de uma só carne

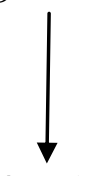

2) todas as versões desse corpo/as dimensões de uma só frase

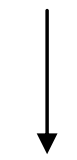

3) que ela, sem se decompor/ revela então em intensidade ${ }^{152}$

Sem maiores detalhes analíticos ${ }^{153}$, não se poder deixar de admitir que entre (02) e (03), mas não entre (1) e (2), há um alto grau de

\footnotetext{
${ }^{151}$ Pasta Pi. Serial, fo 58.

152 Os versos que antecedem cada cada uma dessas sequências são equivalentes: 1) "[quem] queira apreender os sentidos/que se contêm na sua frase:"; 2) [quem] queira apreender os sentidos/ entranhados no corpo frase:"; 3) "[quem] queira prender todos os temas/que pode haver no corpo frase:".
} 
distorção. Seguindo Fuchs, pode-se dizer que entre (02) e (03) há uma operação parafrásica (se se admite uma significação "larga" de paráfrase) que ultrapassa o limite de distorção, instaurando um semantismo fortemente deformante.

${ }^{153} \mathrm{Cf}$. a análise detalhada que fizemos dessa série reformulativa no $1^{\mathrm{o}}$ capítulo da $3^{\mathrm{a}}$ parte. 


\section{5. Paráfrase: equivalência e assimetria}

A crítica de Catherine Fuchs ao estatismo inerente à noção de equivalência, muito embora vários de seus termos e esquemas de certa forma refiram implicitamente a teoria de Bernard Pottier, não poderia ser, rigorosamente, a ele dirigida. O próprio linguista, ciente das diferenças de sentido produzidas pela operação reformulativa, já notara o seguinte com respeito ao problema da equivalência e da assimetria nas relações parafrásicas, ao comentar o título de um artigo de JeanPierre Desclés:

Jean-Pierre Desclés intitule un des ses articles : «La paraphrase n'est pas une relation d'équivalence, mais une relation asymétrique». Selon les cas étudiés, il nous semble que l'une ou l'autre de ces relations domine, sans qu'il y ait nécessairement incompatibilité. ${ }^{154}$

É preciso, pois, atentar para a especificidade dos casos estudados e verificar se se trata preponderantemente de uma relação de semelhança ou de diferença de sentido entre os enunciados. Na medida em que ambas as relações são compatíveis, é necessário descrever as equivalências semânticas introduzidas pela reformulação, sempre ascendendo ao nível conceitual necessário, ao mesmo tempo que não se deve negligenciar as assimetrias, sobretudo quando estas são dominantes.

No entanto, uma questão se pôe: uma equivalência será sempre encontrada na cadeia reformulativa, não importando o nível conceitual ao qual a interpretação da cadeia deva elevar-se?

Para os "construtivistas", segundo a classificação de Jean-Jacques Franckel (veja-se supra nota 119), na qual estaria incluída Catherine Fuchs, o principal a fazer pelo intérprete das séries parafrásicas não é

${ }^{154}$ La paraphrase textuelle..., art. cit, p. 42 , nota $\mathrm{n}^{\mathrm{o}} 6$. 
procurar o núcleo sêmico comum a essas séries, mas descrever as diferenças instauradas a cada reformulação. Mais, para tais teóricos o sentido pode se deslocar de tal modo na reformulação que é possível produzir uma paráfrase que diz de outra forma uma coisa diferente.

No entanto, a teoria de Bernard Pottier, é tudo menos estática, e o autor não ignora casos de reformulações deformantes. Quando ocorre o predomínio da equivalência, podemos, seguindo sua terminologia, chamar tal relação de "parasêmica". Quando porém a assimetria domina e os enunciados têm sentidos fortemente dessemelhantes, de tal maneira que dizem coisas diferentes, teremos uma relação de "heterosemia"155. E uma dinâmica que leva, no âmbito da produção do sentido, de uma parasemia para uma heterosemia é perfeitamente possível. Usando esquemas de Bernard Pottier, poderíamos, por nossa conta, fazer a seguinte representação dessa passagem:

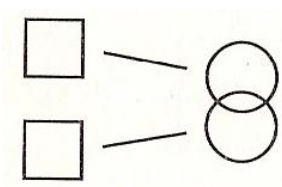

parasemia

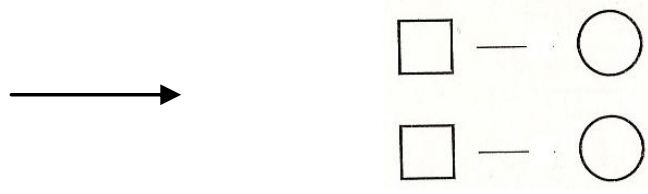

heterosemia

Tomemos um exemplo de Cabral, já referido, para exemplificação:

${ }^{155}$ Cf. Théorie et analyse en linguistique, op. cit., pp. 52 - 53. 


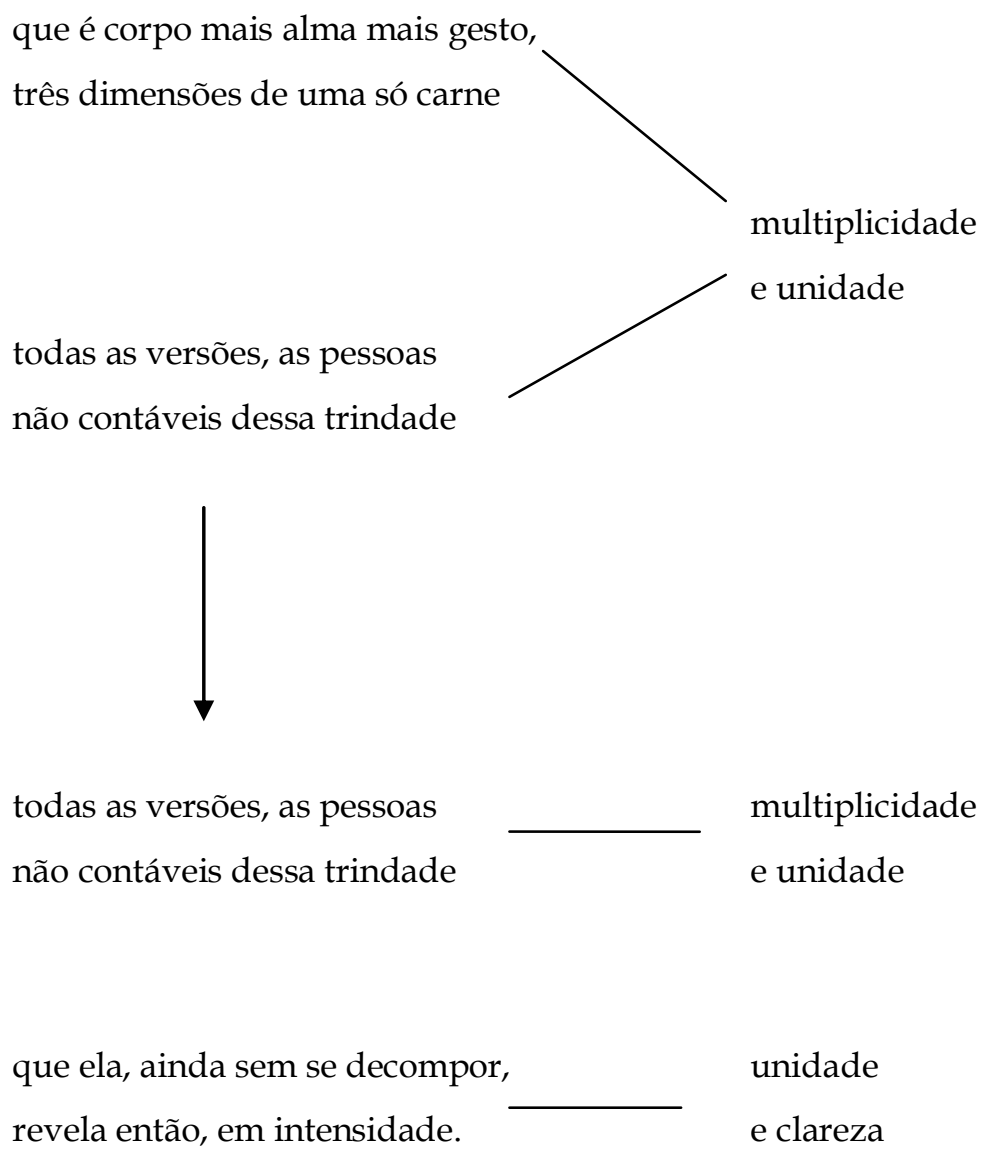

A produção de uma heterosemia, se se leva à risca as definições de Bernard Pottier, não configura propriamente uma paráfrase, já que as formas parafrásicas, segundo o linguista, deveriam ter necessariamente um núcleo semântico comum entre si. Assim, o termo paráfrase somente seria utilizável nesse caso se aceitarmos uma concepção "larga" da relação parafrásica, que inclui a distorção, proposta por Fuchs, mas que não existe em Pottier. De qualquer forma, não deixaria de haver, na passagem de uma parasemia para uma heterosemia, uma reformulação textual. 


\section{6. Análise genética da paráfrase}

Segundo Catherine Fuchs, os manuscritos nos põem diante de casos de reformulação "tout à fait particulières". E essa particularidade é assim descrita pela autora:

Il s'agit de la suite plus ou moins longue d'auto-formulations, à travers laquelle un scripteur construit progressivement son texte. La specificité de ce type de reformulation réside en ce que qu'il n'existe pas de Tsource tout constitué au départ [...] À l'évidence, le sujet dispose rarement d'un contenu déjà-là, prêt à se voir paré de tellle ou telle forme d'expression; sous des modalités diverses, qui varient d'un sujet à un autre, c' est à un incessant aller et retour entre la forme et le fond que se livre le scripteur, le contenu s'élaborant et se stabilisant progressivement à travers diverses tentatives de formulation ${ }^{156}$

Ou seja, para a autora, as "auto-reformulações" efetuadas por um escritor, durante o processo de produção de um texto, difere da operação paráfrasica que retoma um conteúdo já dado no início para expressá-lo tal e qual de outra maneira, seja, por exemplo, para se fazer mais claro, seja, outro exemplo, para se coadunar a um contexto que requer certo decoro linguístico. No caso da criação escrita, segundo Catherine Fuchs, aquilo que se quer dizer se instaura e se estabiliza durante o processo mesmo de reformulação, quando o scripteur lança mão de diversas formas linguísticas que se substituem progressivamente. $\mathrm{O}$ escritor, dessa maneira, partiria de algo indeterminado, um conteúdo não completamente constituído, um texto inacabado que vai sendo feito por variação, por reescritas. Há pois uma certa ignorância, por parte do scriptor, do que vai dizer ou fazer, algo que somente se descobre com a operação reformulativa.

156 FUCHS, Catherine. Paraphrase et énonciation, op. cit., p. 17. 
Catherine Fuchs, em outros de seus textos, já dera como exemplo desse procedimento de "découverte" - e não de "mise en forme"157 - o manuscrito de um estudo sobre Saint-Beuve escrito por Marcel Proust ${ }^{158}$. Em seu estudo sobre esse documento, a autora mostra todo o percurso hesitante de Proust em chegar à forma definitiva da frase "Ce n'est qu'en cachette d'elle [de l'intelligence], hors de sa zone de lumière que l'artiste peut trouver la realité perdue et la recréer". Adaptamos para os nossas convenções a transcrição da passagem do manuscrito analisada por Catherine Fuchs:

${ }^{157}$ As expressões são de Almuth Grésillon e Jean-Louis Lebrave, citados por Fuchs na p. 17 de Paraphrase et énonciation, op. cit. Damos aqui a citação completa que reafirma a tese de que o pensamento não está, durante a atividade de escrita, completamente constituído antes da sua semiotização, mas, diferentemente, que é pelas tentativas de semiotização que se descobre o que se quer dizer: "L'écriture ne saurait être considerée comme une simple mise en forme d'une "pensée" toute faite dont on chercherait seulement $\mathrm{l}^{\prime \prime}$ "expression" adéquate: elle est recherche et découverte beaucoup plus que mise en forme".

158 Analisados pela autora em La paraphrase, op. cit. pp. 139-147 e em « Élements pour une approche énonciative de la paraphrase dans les brouillons de manuscrits » in $\mathrm{La}$ genèse du texte: les modèles linguistiques, op. cit., pp. 73 - 102. É preciso também fazer menção aqui ao estudo sobre a paráfrase no manuscritos de Marcel Proust levado a cabo por Almuth Grésillon, Jean-Louis Lebrave et Catherine Viollet "Une histoire à dormir debout. Le jeu des paraphrases dans les Cahiers de Proust". In : Proust à la lettre. Les intermittences de l'écriture. Tusson (Charente) : Du Lérot, 1990. O objetivo dos autores foi analisar as diversas reformulações, desde seus primeiros esboços, pelas quais passou o tema proustiano do "dormeur éveillé", cuja forma final acabou por se transformar no incipit de À la recherche du temps perdu ("Longtemps je me suis couché de bonne heure"). Segundo os autores, esse incipit nasce da tentativa de Proust de resolução de um "conflit énonciatif" entre um "je", que representa o narrador cuja experiência é única, e um "celui qui" que representa um sujeito genérico, cuja experiência é repetitiva; nas palavras dos autores: "le jeu presque interminable des paraphrases n'avait en dernière instance qu'un seul sens: mettre en place cette alternance-identité entre un " $\mathrm{je}$ " singulier et le "on" répresentant tous les jeunes gens qui dorment" (p. 105). Quer dizer, tratava-se, no caso desses manuscritos referidos de Proust, não exatamente de encontrar o melhor enunciado para o "dormeur", mas como afirma Grésillon, em outro texto onde retoma o problema (Eléments de critique génétique, op. cit., p. 155) "de savoir qui devait ainsi dormir et se réveiller". O conflito enunciativo resolvido por Proust, encontra, assim, sua solução somente no movimento mesmo da escrita. 
1) C'est n'est pas en elle que nous pouvons trouver cette realité, cette seule matière où peut s'exprimer...

identité...

2) E'est n'es pas en elle...

3) En elle l'artiste cherchera

4) C'est n'est en elle que l'artiste peut trouver la réalité

5) Elle ne retient rien de la réalité

6) Eette realité qui est la matière

bornes

7) C'est n'est qu'en cachete d'elle, hors des confins de sa lumière de sa zone de lu-

limites

trouver

mière que l'artiste peut-aper retreuver la réalité perdue et la recréer. ${ }^{159}$

A autora vê, no percurso reformulativo de (1) até (7) a ausência de uma intenção de significação precisa e totalmente determinada, e assere que, portanto, são "les tentatives d'expression qui permettent à l'auteur de préciser progressivement son intention, initialement vague $^{\prime \prime 160}$. Ou seja, a conceitualização torna-se mais precisa, na medida em que Marcel Proust busca sua expressão por meio de variações das relações predicativas, da constituição de valores referenciais e da designação dos termos.

Um estudo sobre outra série parafrásica, desta vez a que acabará por se tornar o incipit do conto "Herodias" de Gustave Flaubert, ao invés de mostrar o decurso de estabilização da intenção de significação, mostra como uma conceitualização já bem definida pode passar por um processo de verbalização complexo. Referimo-nos ao estudo "Ruminer Herodias: du cognitif-visuel au verbal-textuel" escrito por Catherine

159 Para a transcrição proposta por Catherine Fuchs, impossível de ser reproduzida aqui, ver Élements pour une approche énonciative de la paraphrase, art. cit. p. 99. 160 La paraphrase, op. cit. pp. 140 e 145. 
Fuchs, Almuth Grésillon et Jean-Louis Lebrave ${ }^{161}$. Nesse estudo os autores analisam os mecanismos de reformulação postos em funcionamento por Flaubert a fim de chegar a uma descrição objetiva da cidadela de Machaerous, que constitui o começo do conto "Herodias". Essa descrição objetiva, Flaubert já a tinha ao começar a escrita do texto, mas não sua formulação satisfatória. Os autores do estudo tentam, portanto, revelar o percurso que leva da seguinte descrição "Machaerous était, au temps des Césars Romains, la place militaire la plus forte de toute la Palestine", concebida desde o início de gestação do conto, até a seguinte descrição “La citadelle de Machaerous se dressait à l'Orient de la mer Morte, sur un pic de basalte ayant la forme d'un cône etc." , que figura no texto definitivo.

Segundo os autores, dois tipos de reformulações são efetuadas por Flaubert, por eles nomeados de intertextuais e intratextuais. As primeiras indicam uma "activité de recueil d'indices, de termes, de définitions, empruntés à divers auteurs, qu'il [Flaubert] séléctionne, recopie et retravaille inlassablement avant de les fondre dans son texte"162. As reformulações intratextuais, por sua vez, são reorganizações efetuadas por Flaubert de seu próprio texto, e que consistem tanto em "modifications locales" quanto em "altérations beaucoup plus complexes"163.

Com relação às reformulações intertextuais, os autores mostram que pouco delas é aproveitado no texto final. Assim sendo, concluem que se trata menos de um processo de semiotização propriamente dito do que de uma "ginástica" de escrita, um "aquecimento" para o trabalho efetivo de realização do texto. Em suas palavras:

161 FUCHS, Catherine, GRÉSILLON, Almuht e LEBRAVE, Jean-Louis. Ruminer Herodias: du cognitif-visuel au verbal-textuel. In: L'écriture et ses doubles. Genèse et variation textuelle/ed. por HAY, Louis. Paris: Éditions du CNRS, 1991, pp. 28 - 109.

162 Idem, ibidem, p. 69.

163 Idem, ibidem. 
la lecture-écriture des sources documentaires constitue-t-elle pour Flaubert une sorte de gymnastique de l'écriture, d'incubation et $\mathrm{d}^{\prime}$ «échauffement» nécessaires au lancement de son propre discours. Après quoi il est en effet compréhensible que le scripteur n'ait plus, ou presque plus, besoin d'autrui pour écrire son propre texte. ${ }^{164}$

Com relação às reformulações intratextuais, os críticos vêem duas séries, uma que representa modificações complexas, e outra, modificações locais. A primeira série mostra como Flaubert progressivamente abandona uma formulação cujo conteúdo possui várias marcas subjetivas em prol de outra formulação onde tais marcas desaparecem. Por exemplo, Flaubert substitui o texto "dont [de la forteresse] la hauteur semblait prodigieuse" por "dont la hauteur était inaccessible», depois por "“dont l'apparence était formidable". Comentam os autores que essas três expressões são "modulations d'une même appréciation subjective: l'effroi d'un étranger découvrant la caractère 'inexpugnable' de la forteresse"165. Ora, no último estado das correções, essas adjetivações que indicam uma apreciação subjetiva são deixadas de lado por inteiro em favor de um texto modalizado objetivamente. Citemos os autores:

dans le dernier état de corrections sur le premier jet, le jugement subjectif disparaît, tandis que l'aspect lisse [de la forteresse] est renforcé par une comparaison avec le marbre : "à la forteresse, dont les murailles de 120 coudées étaient plus lisses que du marbre ${ }^{166}$

O que se observa, portanto, nas reformulações intratextuais complexas efetuadas por Flaubert é o abandono de uma perspectiva subjetiva de apreciação, e o progressivo movimento em direção à descrição objetiva feita pelo narrador. O dado subjetivo, no entanto,

164 Idem, ibidem, p. 85.

165 Idem, ibidem, p. 86.

166 Idem, ibidem, p. 89. 
segundo os analistas desse manuscrito, não será eliminado, mas reservado para o discurso da personagem Antipas sobre a mesma paisagem ${ }^{167}$. Finalmente, com respeito às reformulações intratextuais locais, que incidem sobre a pontuação, a ordem das palavras, as construções sintáticas e as escolhas lexicais, elas mostram apenas ajustamentos pontuais que servem para corrigir alguma dissonância semântica e para fixar, em definitivo, o ritmo do texto. Conforme afirmam os autores:

Flaubert profite de ces dernières relectures pour corriger un détail dissonant (déplacement d'un détail qui risquerait de "subjectiviser » la description, ultime mise au point du coup d'œil de l'observateur extérieur sur la citadelle) ou pour soupeser la ponctuation et tester les pauses de souffle qui donneront au texte son rythme définitif. ${ }^{168}$

Comparemos o caso de João Cabral com esses dois exemplos de reformulação parafrásica, o de Proust, onde a conceitualização se precisa durante o processo também instável de semiotização, e o de Flaubert, onde se verifica uma continuidade desde a visão conceitual do início até a formulação final, não sem, evidentemente, algumas retificações de ordem semântica e sintática.

O manuscrito de Marcel Proust, mostrado acima, tem certas semelhanças com o manuscrito da $3^{\text {a }}$ parte do poema “O mercado a que os rios"169 de João Cabral, onde se pode observar que o conteúdo da primeira estrofe não está todo constituído de antemão, mas que, diferentemente, se estabiliza conforme o autor reformula, de forma tateante, os versos:

\footnotetext{
167 Idem, ibidem, p. 90.

168 Idem, ibidem, p. 76.

169 Pasta Pi. Poemas pernambucanos, sem indicação de fólio. A versão final do texto encontra-se em Obra completa, op. cit., p. 453.
} 


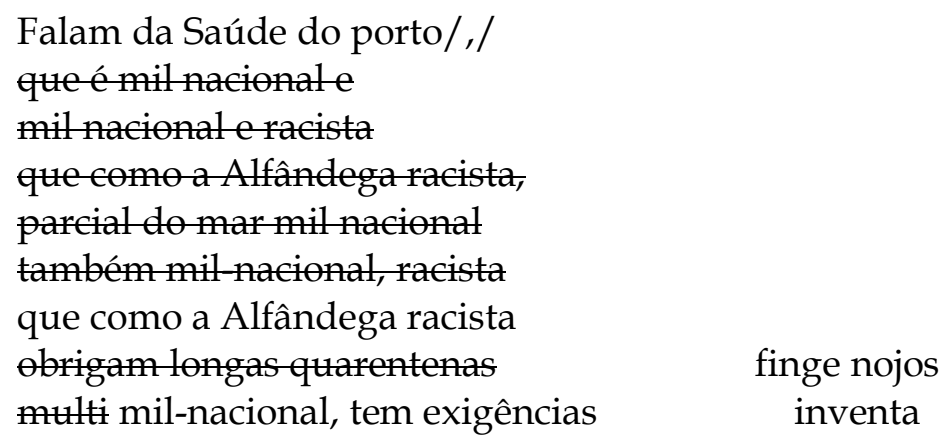

É notável que João Cabral, nesse exemplo, somente chega a escrever a estrofe que inicia a $3^{\mathrm{a}}$ parte do poema depois da rasura sucessiva das primeiras formulações. Por exemplo, o segundo verso ("que como a Alfândega racista") assume uma certa estabilidade depois de cinco tentativas de semiotização. Mais: uma predicação tão importante quanto a comparação da "Saúde do porto" com a "Alfândega" inexiste ainda até a terceiro ensaio formulação. E tudo isso é ainda provisório. Na margem esquerda do fólio, o autor retoma por duas vezes a passagem, ainda de forma tateante. Na primeira retomada, temos:

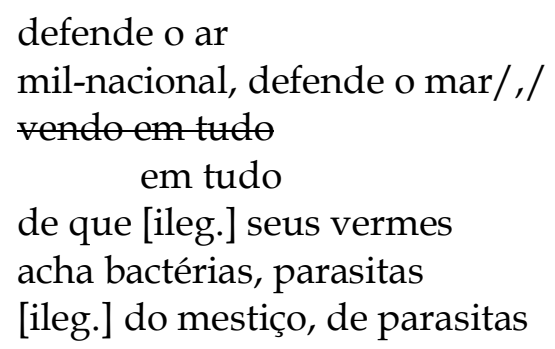

Trata-se de uma tentativa fragmentária de reformulação dos dois últimos versos da estrofe. Os fragmentos introduzem elementos ("defende o mar", "do mestiço") que desenvolvem o caráter racista do protecionismo da Âlfândega, ao mesmo tempo que transforma sensivelmente a representação do excessivo cuidado sanitarista da 
Saúde do porto, com os termos "vermes", "bactérias", "parasitas". Agora, na segunda retomada, que damos a seguir:

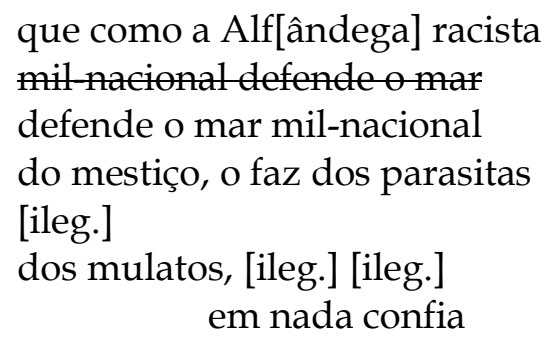

é possível ver a transformação do caráter "racista" da Alfândega por meio de uma peronímia ("defende o mar mil-nacional/do mestiço <dos mulatos>"); por outro lado, o caráter asséptico da Saúde do porto, que na primeira versão era representado por uma metáfora ('tem exigências/de enfermeira inglesa ou suíça"), se ortononimiza ("em nada confia"). Essas reformulações serão aproveitadas na versão final publicada, não sem algumas retificações, das quais não há traços genéticos:

\section{Falam da Inspeção de Saúde que (como a Alfândega racista defende o mar mil-nacional da água mulata) em nada fia.}

Como, para chegar até esta versão, João Cabral modificou sucessivamente todos o versos, é difícil afirmar que tinha uma concepção completa da estrofe que queria escrever antes do processo de semiotização. Diríamos, diferentemente, que a determinação de seu querer-dizer somente se dá com o processo mesmo de escrita na página, através de operações reformulativas repetidas muitas vezes, e que acabam por instaurar diferenças entre as primeiras e as últimas representações. Semelhantemente a Proust, João Cabral parece, neste 
exemplo, conceber o sentido de seu poema apenas no decorrer da atividade de reformulação.

Agora, assim como em Flaubert, as retificações em Cabral também servem, guardadas as diferenças, à constituição do estilo. Em Cabral especificamente, elas podem servir à composição de sua sintaxe própria, sem que haja uma modificação da conceitualização de base. Damos aqui um pequeno exemplo, o prototexto do poema "Os vazios do homem"170, do qual transcrevemos o começo:

não sentem ao

Os vazios do homem divergem do nada

do do casaco

do vazio qualquer; exemplo, $\theta$ vazio

$<$ do $>$ da saca vazia $/: /<$ que esta não ficam de pé vazios

quando vazia ou o homem com vazios.

É possível perceber neste prototexto que a substituição exemplo $\rightarrow$ do do casaco acarreta ajustes de sintaxe que tranformam um texto explicativo em um texto elíptico, como, por exemplo, a repetição da forma "do da", e bem se sabe que a elipse é uma das marcas do estilo cabralino. Note-se também a construção incomum "não sentem ao" que substitui a mais usual "divergem do".

Por meio desses dois exemplos, viu-se que é possível identificar, em Cabral, seja a progressiva clarificação do conteúdo do texto por meio da semiotização tateante na página, seja a busca de formas equivalentes que não desviam da intenção de significação inicial, que já está estabilizada, mas que instauram o estilo sintático.

170 Pasta Pi. A educação pela pedra 1. fólio 30. O poema publicado encontra-se em Obra completa, op. cit. p. 359. 
As duas teorias de paráfrase - de Bernard Pottier e de Catherine Fuchs, analisadas mais acima - são de grande valia para analisar esse tipo de escrita, pois nos fornecem instrumentos que permitem identificar e analisar as relações entre os diversos estados do percurso reformulativo, determinando a equivalência, mas também as diferenças entre as diversas reformulações efetuadas. Teremos a oportunidade, na terceira parte desta tese, de multiplicar os exemplos das reformulações operadas por Cabral, através da análise de diversos manuscritos. Ali veremos que ao lado da construção de séries parasêmicas que tornam progressivamente mais precisa uma representação, há também a instauração de heterosemias que modificam radicalmente os sentido e a estrutura do poema, ultrapassando-se, assim, o limite de deformabilidade aceitável para que os estados do texto sejam considerados equivalentes. 


\title{
Capítulo 3. Poiética e crítica genética
}

\section{1. Duas críticas da poiética à genética textual}

\author{
Ainda que poiética e crítica genética sejam exatamente \\ contemporâneas (ambas nascem no começo da década de 70), \\ pertençam ao mesmo ambiente cultural (francês) e tenham o mesmo \\ objeto (a criação em ato), nenhum verdadeiro debate sobre a relação \\ entre ambas foi estabelecido. Numas das poucas referências existentes \\ de uma à outra, René Passeron traça a seguinte diferença entre as duas \\ disciplinas:
}

La "génétique des textes", pratiquée par la revue Genesis, connote une idée de programmation et se limite à des documents écrits, alors que la poïétique s'interesse plutôt aux actes (dans un brouillon biffé, c'est la biffure qui l'interesse) - même si ces actes n'ont pas laissé de trace. Elle se veut particulièrement sensible à l'imprevisible. ${ }^{171}$

René Passeron, assim, estabelece duas divergências entre crítica genética e poiética:

1) a conotação de uma ideia de programação presente no conceito de "gênese" leva a pensar o nascimento da obra de arte como

\footnotetext{
171 PASSERON, René, La naissance d'Icare, op. cit. p. 77). Cf. também o que é escrito pelo autor em Exclamations philosophiques, suivi de Thèmes, Paris, L'Harmattan, 2003, p. 93: “Et je dis bien, activité (poïétique), et pas seulement devenir (génétique). Car toute genèse est planifiée, alors que la création est imprévisible». E em nota a essa passagem : "Ainsi, l'examen des brouillons de Flaubert par Pierre-Marc de Biasi, et les travaux de la revue Genesis relèvent bien de la poïétique: les biffures et les modifications de l'œuvre-en-train dépendent en grand partie du libre-arbitre de l'écrivain. »
} 
análogo ao processo biológico: a obra estaria, assim, de certa forma antecipada desde o início do processo (tal como o comportamento de um indivíduo está "programado" por seu código ADN)172; a poiética por sua vez pensa a criação como constituída por atos que instauram uma realidade que é ignorada pelo sujeito criador, sendo, portanto, imprevisível;

2) a crítica genética se interessa pelas operações escritas enquanto materializadas nos manuscritos, reconstituindo a gênese retrospectivamente; a poiética, por seu turno, pensa o ato criativo independentemente da existência ou não de seu traço, abordando a instauração da obra de uma maneira inspectiva.

Tratemos separadamente das duas diferenças, nos dois subcapítulos que se seguem.

172 Para um maior desenvolvimento da diferença entre os conceitos de genesis e poiesis, ver o ensaio de René PASSERON. Création e gênèse. Recherches Poiétiques, 2000, n9, pp. $101-109$. 


\section{2. Programação e processo, projeto e trajeto}

Há de fato na crítica genética a ideia de programação da obra. Mas não se trata de um conceito absoluto, muito ao contrário. Encontramos tal ideia na classificação das condutas criativas literárias proposta por Louis Hay, inventor da expressão "crítica genética", que estabelece dois tipos de escrita, a programática e a processual. Na escrita programática, segundo o autor, "estamos em presença de uma mecânica genética que determina e comanda invariavelmente um mesmo processo de escritura"; ela tem, pois, "um caráter fortemente prospectivo e controlado"173. A escrita processual, por sua vez, é um "processo genético que ignora as estratégias programadas, os detalhes de planificação e cuja matéria é tecida na lançadeira da escritura"174. A escrita programática, segundo a definição de Louis Hay, premedita a obra-a-fazer, controlando, assim, o processo de realização das estruturas e do conteúdo concebidos; na escrita processual, por sua vez, a obra se revela durante o percurso mesmo de sua instauração.

Um dos exemplos de escrita programática dado por Louis Hay é o de Émile Zola ${ }^{175}$. Os manuscritos de L'assomoir mostram que Zola, segundo Hay, começa com um "projeto prospectivo", que o próprio romancista chama de "O Esboço" ao qual se ajuntam as seguintes etapas de concepção e realização:

\footnotetext{
${ }^{173}$ HAY, Louis, A literatura dos escritores. Questões de crítica genética, op. cit. p. 62.

174 Idem ibidem, p. 64.

175 Gustave Flaubert é outro exemplo de conduta programática dos mais citados. Pierre-Marc de Biasi descreveu, por exemplo, em 8 etapas o processo de escrita do conto "La légende de Saint Julien l'Hospitalier": 0) le scénario initial, 1) scénario developpé, 2) ébauche/brouillon I, 3) ébauche/brouillon II, 4) ébauche/brouillon III, 5) mise au net I, 6) mise au net II, 7) manuscrit définitif. Ver "Flaubert et la poétique du non finito". In : Le manuscrit inachevé/ed. por Louis HAY. Paris : Édition du CNRS, 1986. pp. $51-52$.
} 
Vêm, sem seguida as "Notas" que enriquecem o programa do "Esboço"; um primeiro "Plano" que estrutura a matéria narrativa em grandes episódios; finalmente um programa detalhado (o segundo "Plano"). Somente no fim dessas operações prévias é que intervém o trabalho de redação ${ }^{176}$

No caso dos escritores processuais, Louis Hay se refere mais mais longamente à Julien Gracq, para quem "um livro nasce de uma insatisfação, de um vazio cujos contornos só se revelarão ao longo do trabalho, e que pede para ser preenchido pela escritura" 177 .

A classificação proposta por Louis Hay se contrapõe à tradicional classificação "escritores inspirados" e "escritores técnicos", incessantemente repetida na história da literatura ${ }^{178}$. Sempre pautado na realidade dos manuscritos, o crítico, na verdade, esvazia o primeiro tipo de conduta criativa (a inspirada) e divide o segundo (conduta técnica). Nessa divisão, a escrita pode tanto ser um ato de pré-visão da obra futura, seguido de sua realização (programática), quanto um enfrentamento do imprevisível (processual). A vantagem dessa classificação é desembaraçar-se do mito de uma escrita espontânea e sem controle algum, de onde estariam ausentes quaisquer reformulações que modificassem sensivelmente a obra179.

\footnotetext{
176 Idem, ibidem, p. 62.

177 apud HAY, Louis, op. cit, p. 63. Mas o exemplo por excelência da escrita processual é Marcel Proust. No capítilo anterior fizemos referência às análises de seus manuscritos efetuadas por Catherine Fuchs e Almuth Grésillon.

178 Essa classificação tradicional é retomada por João Cabral de Melo Neto. Cf. nosso comentário de seus textos em prosa sobre o fazer no $3^{\circ}$ capítulo da $2^{\mathrm{a}}$ parte desta tese.

179 Com relação à escrita automática do Surrealismo, espontânea e incontrolada como a poesia "inspirada", mas por outros motivos, ver a problematização da relação entre "la théorie affichée" e la "pratique réelle" de André Breton a partir da leitura de alguns dos seus manuscritos em SCOPELLITTI, Paolo. "Les avant-textes de l'Imaculée conception". In: La fabrique Surrealiste/estudos reunidos por Maryse VASERVIÈRE. Éditions du CNRS. Disponível em formato eletrônico na página:

http://melusine.univ-paris3.fr/Association/ImagesAssoc/Fabrique_BAT.pdf. O autor lança a hipótese que as diversas reformulações presentes no prototextos surrealistas mostram que a escrita automática não é completamente ditada pelo inconsciente, sendo também consituída por "operações de censura".
} 
Mas a noção de escrita programática é vítima de reservas no próprio âmbito da crítica genética. Irène Fenoglio, analisando em diversos manuscritos as formas linguísticas e enunciativas pelas quais um texto é projetado (título, preparação do tema, pré-determinação do conteúdo, nomes de personagens, cronologia), mostra como a restituição diacrônica de um processo criativo que determina as leis de uma programação ou planificação é presa de uma ilusão retrospectiva:

S'accrocher, dans l'observation des manuscrits, aux formes linguistiques et énonciatives par lesquelles se "prépare" un texte évite de verser dans une intentionnalité téléologique où, rétrospectivement, l'observateur cherche et donc trouve des lois de planification. La diachronie n'implique pas automatiquement une finalité explicitée. ${ }^{180}$

Para Irène Fenoglio pode-se afirmar, portanto, que um texto literário, pelo menos - não é exatamente projetado, mas antes "cherché", procurado e talvez descoberto durante o processo de escrita. Atesta-o o fato, segundo a autora, de nos manuscritos encontrarmos uma heterogeneidade entre "l'annonce de l'écrire, le dit projeté (par un dire méta) et le dit final effectif"181, portanto, uma diferença entre o que foi pré-visto e o que foi realizado.

A ideia de uma programação completa foi também criticada por Almuth Grésillon na análise que fez dos proto-textos de La Bête humaine, de Émile Zola. Como já dissemos acima, Zola é um paradigma da conduta criativa programática. Ora, o que Almuth Grésillon torna manifesto, ao refazer o percurso genético do fim do romance de Zola, em seu texto "Dénouement narratif dans La Bête humaine", é que a cena final do livro, tal como foi concebida, é completamente diversa da versão publicada. Três finais serão pré-visualizados pelo romancista.

180 FENOGLIO, Irène. Du texte avant le texte. Formes génétiques et marques énonciatives de pré-visions textualisantes. Langue Française, 2007, nº 155, p. 34.

181 Idem, ibidem. 
No primeiro, concebido no "Esboço", a personagem principal (Jacques) confessa seu crime; no segundo, concebido no primeiro plano detalhado, a personagem prossegue uma vida "douce et tranquille"; no terceiro, o definitivo, a personagem sofre uma morte atroz ${ }^{182}$. Tais modificações, comenta Almuth Grésillon, não seguem nenhuma lógica interna à obra, mas têm uma origem casual, sobretudo a modificação que leva ao final definitivo, cuja causa é exogenética: Émile Zola começa a conceber o fim definitivo do romance depois de ter lido um artigo de jornal escrito por ocasião de um acidente de trem, e é justamente um acidente desse tipo que se descreve no final da obra ${ }^{183}$. A autora assim resume prospectivamente os resultados de seu empreendimento genético:

Le parcours génétique montrera que l'écriture de Zola, contrairement à une opinion répandue, n'est pas entièrement prémeditée dès le début; que tout étant connue pour être le type même de l'écriture "à programme", elle excelle, pour citer une expression de Claude Simon, à "tâtonner en aveugle" avant de trouver la vraie fin du roman. Le dénouement narratif sera inventé tardivement, à travers des hypothèses contradictoires et des jaillisssements impromptus. ${ }^{184}$

Ou seja, e essa é a conclusão de Almuth Grésillon, o imprevisível, o incerto está sempre presente nas condutas criativas, mesmo as mais pretensamente planificadas e controladas como a de Émile Zola. Muitos dos trabalhos de Almuth Grésillon vão exatamente no sentido de determinar o lugar dos aspectos não programáveis, não previsíveis, não predizíveis da atividade criativa. Na parte teórica de seu livro Mise en oeuvre. Intinéraires génétiques, a partir de textos de Pierre Boulez sobre a criação, Almuth Grésillon afirma com segurança que "la possibilité de l'accident est [...] essentielle pour l'acte de création", ou seja, que não há

182 GRÉSILLLON, Almuth, La mise en oeuvre. Intinéraires génétiques, op. cit., p. 154.

183 Idem, ibidem, 143-144.

${ }^{184}$ Idem, ibidem, p. 138. 
absolutamente a garantia da realização de um projeto concebido em qualquer conduta de criação literária. O acidente, porém, não é a abolição da previsibilidade, mas a integração do "imprévisible dans le prévu", e que, portanto, a criação é uma confrontação entre uma posição decisional e um acontecimento acidental, entre a "vision globale" e o "accident de l'instant", o "hasard aboli" e o "libre arbitre preservé" entre "primauté de l'ordre et trangression de la loi"185.

Há, como se pode ver, na teoria de Almuth Grésillon, a tendência de absolutizar a noção de processo - ao mesmo tempo que relativiza a noção de programa -, tornando-a fundamental para compreensão de qualquer trabalho de escritura. Na restituição da ordem sucessiva da instauração da obra, tarefa do crítico genético, segundo Grésillon ${ }^{186}$, haverá não um caminho em linha reta do plano à realização, mas um percurso mais ou menos desviante.

No entanto, não somente o conceito de programa, mas o conceito mesmo de processo não escapa dos desdobramentos críticos da teoria da gênese textual. O livro de Claudia Amigo Pino e Roberto Zular, Escrever sobre escrever: uma introdução crítica à crítica genética, é, nesse sentido, exemplar. $\mathrm{O}$ autores partem da tese de que a relação entre os enunciados produzidos no trabalho de produção literária não pode ser apreendida, sob pena de artificialidade, por meio da categoria de tempo, ou seja, por meio da noção de processo que se divide em etapas cronológicas sucessivas. O novo modelo teório proposto por Claudia Amigo Pino e Roberto Zular é, foucaldianamente, “arqueológico”. Quer dizer, no trabalho de escrita, os enunciados produzidos não se subordinariam entre si em uma continuidade cronologicamente determinada, mas se justaporiam em séries descontínuas. Ao

185 As expressões citadas nessa frase são todas de Pierre Boulez, ao qual Almuth Grésillon abundantemente faz referência. Ver GRÉSILLON, Almuth. Mise en oeuvre, op. cit. pp. $12-13$.

${ }^{186}$ Idem, Élements de critique génétique, op. cit. p. 31. 
paradigma cronológico do processo, os autores contrapõem o modelo topológico de "espaço de relações":

Como identificar esse enunciado-relação em um conjunto de manuscritos? Uma parte da resposta já é sabida: pelas descontinuidades. Porém, as rasuras estabelecem somente diferenças, quebras, não relações. Nesse momento, entra o olhar do pesquisador. Ele deve reunir essas diferenes rasuras a partir de identidades, criando dessa maneira um espaço de relações. ${ }^{187}$

A noção de descontinuidade radicaliza a de desvio. O crítico genético, assim, não reconstituiria as "etapas" da criação, mas organizaria o trabalho de escrita por meio de "recortes". A crítica é pertinente na medida em que aponta para certa "autonomia" dos documentos com relação a outros de um mesmo dossiê genético. Evitando subsumir os documentos a "fases' do processo, criando assim um homogeneidade temporal ilusória, os autores preferem separá-los por recortes, enfatizando as diferenças entres tais documentos os quais fariam parte, finalmente, de um conjunto espacial heterogêno.

Porém, na medida em que, para João Cabral, o trabalho de criação literária se entende através da tensão entre plano e execução (programa e processo), são sobretudo a esses conceitos que nos referimos. Se a atividade de criação, pensada como um híbrido de prédeterminação programática e desvios processuais, pode, com proveito, ser utilizada para a descrição do fazer cabralino, deve-se, portanto, relativizar a metáfora do poeta-arquiteto com que é conhecida sua conduta. Há realmente, em Cabral, por um lado, a pré-visão de alguns aspectos da obra, sobretudo no nível macro-estrutural (por exemplo, a quaternidade de Serial e a dualidade de A educação pela pedra); há também em Cabral a pré-determinação do esquema métrico, do

187 PINO, Claudia Amigo; ZULAR, Roberto. Escrever sobre escrever: uma introdução crítica à crítica genética, op. cit. p. 46. 
esquema rímico e do número de partes do poema. Ou seja, existem de fato coerções formais auto-impostas por Cabral que ele se obriga a observar. Mas, por outro lado, as estruturas semânticas e sintáticas, além das relações entre as partes do poema não são de forma alguma completamente determinadas, já que se observam em seus manuscritos mudanças profundas estabelecidas depois da composição dos textos. $\mathrm{Na}$ terceira parte desta tese mostraremos em detalhe como ocorrem essas modificações sem teleologia rígida.

Voltemos à primeira crítica de René Passeron ao conceito de gênese. Se dele é indissociável a noção de programação, é na medida em que a consideramos do ponto de vista biológico. Do ponto de vista da criação, à gênese é essencial o imprevisível, o incerto, o acidente, como o afirmam os próprios téoricos da genética textual. Nesse sentido, a oposição proposta por Passeron entre uma filosofia do trajeto e uma filosofia do projeto ${ }^{188}$, sua oposição da ideia de uma conduta criativa, que preenche o vazio da obra a fazer, à noção de uma conduta eidética, que realiza formas concebidas a priori, não entra em conflito com a teoria da criação desenvolvida pela crítica genética que descobre a necessária conjugação entre $\mathrm{o}$ procedimento processual e $\mathrm{o}$ procedimento programático.

188 Ver Pour une philosophie de la création, op. cit., p. 128. 


\section{3. O ato criativo e seu traço}

A segunda diferença estabelecida por René Passeron entre crítica genética e poiética diz respeito ao procedimento metodológico de ambas as disciplinas. A crítica genética aborda a criação indiretamente, através dos traços manuscritos do ato de escrita. A poiética, por seu turno, se debruça sobre o ato instaurativo independentemente da existência de seus indícios.

No estabelecimento dessa diferença, René Passeron aponta para um limite epistemológico da crítica genética. Restringindo-se à análise dos vestígios prototextuais da conduta de criação literária, a crítica genética se calaria quanto aos atos sem rastros. Ora, tais atos existem. Assumindo uma postura fenomenológica e a exigência de que o pesquisador seja ele mesmo um criador, a poiética enfrenta o enorme problema de fixar em discurso teórico a relação entre ação criadora e a reflexão crítica.

A crítica genética não poderia adotar essa atitude poiética por causa de uma coerção de cientificidade, que está na base de seus princípios metodológicos. Ela colocou o manuscrito como seu objeto científico, para, através dele, buscar um conhecimento mais preciso das "operações sistemáticas da escrita - escrever, acrescentar, suprimir, substituir, permutar" - e, para além disso, lançar conjecturas sobres as "atividades mentais" subjacentes a tais operações ${ }^{189}$. Para tanto, a crítica genética armou-se de uma metodologia próxima daquela do estruturalismo, como esclarece Almuth Grésillon:

${ }^{189}$ GRÉSILLON, Almuth. Élements de critique génétique, op. cit., p. 15. 
Dans la mesure où toutes mes lectures procèdent pour l'essentiel de la comparaison entre, respectivement, une forme [mot, sytagme, phrase, suite d'énoncés] " $a$ " et sa récriture en " $b$ " (puis en " $c$ ", " $d$ ", etc.) et qu'elles essayent systématiquement d'évaluer les identités et le différences entre " $a$ " et " $b$ " (puis " $b$ " et " $c$ ", etc.) elles restent, mutatis mutandis, fidèles au principe structuraliste. ${ }^{190}$

Há uma diferença, porém, esclarece ainda a autora, entre o estrutrualismo textual e genético: no primeiro, a relação estrutural entre as formas linguísticas é de natureza simétrica; no segundo, a relação genética se orienta temporalmente no sentido de uma transformação paulatina das unidades, o que acaba por produzir assimetrias entre elas ${ }^{191}$.

Mas, se, por um lado, a observância do rigor científico reduz a crítica genética ao traço manuscrito e faz com que ela neglicencie os gestos e operações de escrita sem rastros, por outro lado, o fato da poiética valorizar o ato sem vestígios não a levaria a um irracionalismo científico? Pois de fato, na medida em que afirma que seu método privilegiado - mas não o único192 - é "l'observation directe, voire autocritique et introspective de l'artiste au travail"193, a poiética corre o risco de ter diante de si um objeto por demais intangível, insondável, misterioso, sem fixidez material a fim de ser observado tantas vezes quantas forem necessárias. Um ato criador, ainda que guarde semelhanças com outros atos criadores, é único e irrepetível. Isso tornaria a poiética falaciosa, ou, no mínimo um conhecimento puramente subjetivo? Mas, é justamente esse caráter misterioso e fugaz da criação e, ao mesmo tempo, sua realidade indiscutível que, segundo

\footnotetext{
190 GRÉSILLON, Almuth. Mise en oeuvre. Itinéraires génétiques. op. cit., p. 8.

191 Idem, ibidem.

192 Como já afirmamos na primeira parte desta tese, a poiética adota os procedimentos de todas as ciências - humanas ou não -, assumindo, assim, uma posição de pluridisciplinaridade.

193 PASSERON, René. La naissance d'Icare, op. cit. p. 75.
} 
René Passeron, chama a poiética ao rigor, e reclama o conhecimento da criação em seu mistério mesmo:

Rangeons la science des conduites créatives auprès des sciences les plus durement défiées par l'obscurité du réel.

Car il s'agit bien d'une realité, non d'un objet fictif et fantaisiste: l'activité créatrice est un des faits les plus manifestes qui nous soient donnés par l'anthropologie historique [...] Constatons que, si la connaissance scientifique se donne partout pour provende des rapports, la poïétique en fait autant, sans prétendre élucider le mystère [...] d'une fonction créatrice qui serait constituée en dehors des phenomènes observables de création. La poḯtique observe, parfois expérimente. Va-t-on lui démander plus? ${ }^{194}$

Não seremos nós que decidiremos se a poiética merece um lugar ao sol na terra das ciências. Ela ao menos tem a coragem de pôr na ordem do dia o difícil problema da relação entre prática criativa e reflexão crítica. Todo artista - inclusive João Cabral -, que se dispôs a considerar fenomenologicamente sua própria conduta, oferece um material de base para a poiética lançar-se na constituição de uma antropologia que tem com objeto a criatividade humana.

O que nos importa são seus resultados. E diremos diretamente: as pesquisas poiéticas foram as grandes responsáveis pela perspectiva que adotamos ao ler os textos "metalinguísticos" de João Cabral. Como veremos na parte seguinte deste trabalho, a compreensão da atividade criativa de Cabral é uniformemente caracterizada pela metáfora técnica da arquitetura e do polimento. Sabemos o que essas imagens implicam: o poeta traça em sua mente, ou no papel, um projeto - uma representação bem definida - e o realiza por meio do trabalho de enxugamento da linguagem. É um procedimento com uma teleologia rígida, que exclui o imprevisível. Ora, a leitura dos textos poiéticos levou-nos paulatinamente a desconfiar desse paradigma e uma leitura

194 Idem, ibidem, p. 69. 
poieticamente orientada dos poemas de Cabral fez-nos descobrir mil motivos de incerteza em suas representações do processo criativo, representações que analisaremos na parte seguinte desta tese: as metáforas vitalistas da criação e o refazer incessante do poema que trazem, pela porta da frente, a ineludível imprevisibilidade. 


\section{PARTE 2. REPRESENTAÇÃO DA CRIAÇÃO NA OBRA DE JOÃO CABRAL DE MELO NETO}


Nosso objetivo é contribuir para uma melhor compreensão do pensamento de João Cabral de Melo Neto sobre a criação, bem como de sua prática criativa, através de uma leitura poiética de seus poemas "metalinguísticos" e uma intepretação genética de seus manuscritos. O pensamento cabralino sobre a criação será justamente o objeto desta segunda parte, na qual empreenderemos uma análise das diversas representações do fazer literário na obra do poeta, análise que preserva alguns princípios da poiética, ciência e filosofia das condutas criativas, expostos na primeira parte desta tese. Na terceira parte deste trabalho, teremos a oportunidade de analisar os traços genéticos de sua conduta compositiva, utilizando os princípios - expostos na parte anterior - da crítica genética, disciplina que estuda as operações de instauração de textos por meio da análise dos traços manuscritos dessas operações.

Como vimos na parte anterior, os resultados teóricos da poiética, mas também da crítica genética, para além das diferenças epistemológicas de ambas as disciplinas, revelam que o fazer artístico, principalmente o literário, se define, como um processo imprevisível e instável. Isso ocorre porque, em literatura, o principal lineamento operatório que põe em relação sujeito criador e obra "en train" é a reformulação, operação que, por meio de substituições, supressões, acréscimos ou permutações, instaura novas formas textuais que se desviam de - ou retificam - uma intenção de significação inicial, na medida que tais formas são equivalentes ou assimétricas com relação ao texto de origem. Assim, em literatura, uma conduta inteiramente programática aparece como quase impossível, e mesmo um escritor "à programme", como Émile Zola, como vimos na parte anterior, 
encontrava - e por acidente - estruturas que divergiam do programa concebido, no decorrer do percurso criativo.

João Cabral de Melo Neto é também considerado pela crítica literária um escritor arquitetônico, ou programático, cujo processo compositivo seria rigorosamente projetado e controlado. Veremos, no $1^{\circ}$ capítulo desta $2^{\mathrm{a}}$ parte, com que conceitos essa crítica construiu a metáfora do "poeta-arquiteto", que acompanha João Cabral como um epíteto. Nos capítulos subsequentes, veremos, porém, que tal metáfora não pode, de forma alguma, ser absolutizada, como de fato acontece, já que vários textos do poeta que tematizam a criação integram a imprevisibilidade e a instabilidade à conduta criativa literária.

Esses valores processuais - não programáticos - da criação podem ser encontrados na obra do poeta:

1) quando, em seus livros $O$ engenheiro (1945) e Psicologia da composição com a Fábula de Afion e Antiode (1947), Cabral representa a criação por meio do espaço-tempo instável da página branca e por meio de noções e modalidades, expressos em metáforas vitalistas, que relativizam o controle total do processo criativo. É disso que tratará o $2^{\circ}$ capítulo.

2) quando em seu textos teóricos, mormente no ensaio sobre Joan Miró (1952) e no ensaio "Poesia e composição" (1950), bem como em diversos poemas de maturidade (sobretudo a partir de Museu de tudo (1974) João Cabral pensa a criação artística nos termos de um refazer contínuo, portanto sob o signo do inacabamento. Essa será a matéria do $3^{\circ}$ capítulo.

Antes de tudo, porém, trataremos de fazer a genealogia da - e revelar os valores inerentes à - metáfora do poeta-engenheiro e da "mineralização" da palavra, particularmente difundidas entre os 
críticos literários e que representam o fazer cabralino como um processo perfeitamente controlado, da concepção à realização, pela lucidez arquitetônica. 


\section{Capítulo 1. Previsibilidade e estabilidade do fazer: a metáfora do poeta-arquiteto e da mineralização da palavra}

\section{1. O poeta-arquiteto}

O epíteto de João Cabral de Melo Neto, legível na crítica literária dedicada ao poeta, é "poeta-arquiteto" ou "poeta-engenheiro". Arquiteto e engenheiro dizem aqui a mesma coisa, tal como se pode ler na seguinte passagem do crítico João Alexandre Barbosa:

o engenheiro proposto por João Cabral tem mais de arquiteto do que de pedreiro, pois ele não é aquele que realiza por acumulação - pedra sobre pedra - mas aquele que, no branco do papel, traça a figura de um espaço que, por si mesmo, ganha faculdade de nomeação. ${ }^{195}$

Se dividirmos o processo de produção arquitetônico em dois momentos principais, o desenho e o canteiro, seguindo uma proposta de Sérgio Ferro'196, vemos que, no comentário crítico de João Alexandre

195 BARBOSA, João Alexandre. A imitação da forma. Uma leitura de João Cabral de Melo Neto. São Paulo: Duas Cidades, 1975, p. 95.

196 FERRO, Sérgio. Arquitetura e trabalho livre. São Paulo: Cosac Naif, 2006, pp. 105 200. Ver também, do mesmo autor, A história da arquitetura vista do canteiro. Três aulas de Sérgio Ferro. São Paulo: GFAU, 2010. E, finalmente, sobre o mesmo assunto, SIMONNET, Cyrille. Dessin-chantier. Réflexions sur la genèse de l'oeuvre architecturale. Genesis n $\mathrm{n}^{\mathrm{1}}$ 14, 2000, pp. $111-126$. Ambos os autores fazem uma crítica à sobreposição, em arquitetura, do desenho - considerado como espaço de prescrição absoluta - ao canteiro - considerado como espaço submisso de execução. A tese de Sérgio Ferro tem uma base marxista e enuncia que a progressiva transformação do desenho arquitetônico em uma pré-visão sistemática dos operações do canteiro concepção que se desenvolve particularmente na Géometrie descriptive de Gaspar Monge (1799), segundo o autor - é o efeito da violência capitalista de exploração do trabalho, que retira o savoir-faire do operário, na medida em que o subjuga pela 
Barbosa, há uma sobrevalorização do desenho com relação ao canteiro, da concepção do projeto (o traçar "a figura de um espaço") com relação ao trabalho manual (o pôr "pedra sobre pedra"), logo, do arquiteto com relação ao pedreiro, o que instaura uma divisão hierárquica fortemente marcada.

Esse modo de ver o fazer cabralino como uma antecipação despótica da obra a fazer, cujo resultado deverá corresponder ao que foi projetado, é talvez a radicalização de uma atitude construtivista presente, segundo Antonio Candido, já na primeira obra do poeta. Em seu estudo precursor, "Notas de crítica literária - Poesia do Norte"197, Candido intui o construtivismo cabralino como ordenação rigorosa em um todo fechado - o poema - dos materiais sensíveis dados. O crítico explicita o conceito com a seguinte análise do poema “Dentro da perda da memória":

O poema todo parte da imagem - mulher azul - que condiciona quatro pontos principais de ossificação: pássaros, lua, retrato, cabelos. Em torno deles se vêm dispor as outras imagens materiais: flores, olhos, seios, clarinetes, bicicletas, amigos, hierofante, braço. Estas palavras comandam os versos, estruturam o poema e dependem de uma vontade ordenadora que, após havê-los selecionado, os dispõe, dentro da composição, como valores por assim dizer plásticos. ${ }^{198}$

simbolização arbitrária do projeto, que castra sua liberdade criativa. Essa transformação tem a seguinte cadeia de causas: 1 . a corrida capitalista pela mais-valia "reclama a redução da hora social média de produção"; 2. "a redução da hora social média supõe, entre outras coisas, o adensamento dos tempos operacionais mínimos; 3. o adensamento dos tempos precisa da transparência esmiuçada da produção dominada, do objeto a produzir e das etapas de produção; 4. a transparência do objeto a produzir e das etapas de produção passa pelo desenho técnico que os determina. (p. 156).

197 CANDIDO, Antonio. "Notas de crítica literária - Poesia do Norte" in Textos de intervenção. Seleção, apresentação e notas de Vinicius Dantas. São Paulo: Duas Cidades, 2002, p. 137.

198 Idem, ibidem, p. 139. 
A análise mostra como certas imagens materiais têm a função de núcleo gerador de outras imagens que compõem o texto. Este se organiza em torno de um sinal significativo que é o esqueleto do poema; os elementos que o constituem são dispostos segundo um critério seletivo, e submetidos a uma disposição rigorosa. Temos, assim, segundo o crítico, um material bruto sensível transformado pelo trabalho que o ordena em linguagem. Que os constituintes do poema sejam assim dispostos em torno de um centro que os comandam, leva o crítico a afirmar a existência de pelo menos duas operações instaurativas: seleção (de materiais sensíveis), e disposição (ordenadora a partir de núcleos) visando um telos plástico, mais visual que discursivo.

Antonio Candido, nesse mesmo texto, observa que o esforço do poeta se exerce sobre uma sensibilidade instintiva e não reflexiva, aliando-se "ordenação da inteligência" e o "que há de mais essencialmente espontâneo no homem"199. Sendo a matéria dos poemas de Pedra do Sono, segundo o crítico, as relações irrefletidas com o sensível, ainda que a lucidez ordenadora organize os dados daí provenientes, o crítico conclui que, no primeiro livro de Cabral, a poesia “ainda" não é tratada como "um edifício racionalista" 200. Mas, justamente,

\footnotetext{
199 CANDIDO, Antonio. Op. cit, pp. 136-137.

${ }^{200}$ Os grifos são nossos. Antonio Candido, muito tempo depois, em um depoimento dado a Selma Vasconcelos, voltará a caracterizar o construtivismo de João Cabral de Melo Neto, contrapondo-o à "poesia derramada", à poesia que exprime emoções. Afirma o professor: "Eu acho que existe, na obra de João Cabral, muita coerência porque, até na poesia social dele, a gente sente que sua preocupação principal é a construção. Ele é um construtor. [...] O construtor é aquele que vê o poema como um objeto a ser construído metodicamente. A emoção tem que ser transformada em palavras neutras. E, na medida em que ela é neutra, ela comove muito, enquanto a poesia derramada é indiscreta, é a poesia em que o sentimento atrapalha a forma. Parece mais expansão psicológica que construção. Isso nunca aconteceu em João Cabral, mesmo na sua poesia aplicada, na poesia para teatro. Sempre um grande construtor. Por isso, acho que o livro cujo título melhor o exprime é O engenheiro". In VASCONCELOS, Selma (org.), João Cabral de Melo Neto: Retrato falado do poeta. Recife: Editora CEPE, 2009, pp. 153 - 154.
} 
o que se observa na fortuna crítica posterior é o triunfo dessa razão arquitetônica que se tornará absoluta.

É Haroldo de Campos o primeiro a propor mais decisivamente a imagem do poeta-engenheiro em seu artigo "O geômetra engajado" 201. O termo "geômetra", presente no título, já indica o sentido que dá Haroldo de Campos à conduta criativa de João Cabral de Melo Neto, pois sem dúvida refere à geometria projetiva da arquitetura. Isso se torna explícito quando o crítico, falando do livro $O$ engenheiro, lança, metaforicamente, uma hipótese sobre procedimento de composição da obra, que seria arquitetônico:

[João Cabral de Melo Neto representa] a instauração, na poesia brasileira, de uma poesia de construção, racionalista e objetiva, contra uma poesia de expressão, subjetiva e irracionalista. Os poemas de $\mathrm{O}$ engenheiro são como que feitos a régua e a esquadro, riscados e calculados no papel. 202 (O grifo é nosso).

Na citação vemos uma contraposição da conduta construtivista à “poesia de expressão". Essse construtivismo imediatamente depois se explicita pela referência aos instrumentos e às operações do arquiteto (régua, esquadro, cálculo no papel), que são exemplos de uma tabuada milimétrica com a qual João Cabral teria projetado com extremo rigor sua obra. Vê-se mais uma vez, como já vimos em João Alexandre Barbosa, que o desenho se sobrepõe aos trabalhos do canteiro, ou que o programa se sobrepõe ao processo. A antecipação lúcida da forma, por meio de 'réguas, esquadros, cálculos", e a construção rigorosa dessa forma, estão no núcleo da metáfora do poeta-arquiteto.

201 CAMPOS, Haroldo de. Metalinguagem e outras metas. São Paulo: Perspectiva, 1992, pp. 77-88.

${ }^{202}$ Idem, ibidem, pp. $80-81$. 
Haroldo de Campos, junto com os outros teóricos do concretismo, estão entre os maiores propugnadores desse construtivismo projetivo em João Cabral, com a finalidade de incluí-lo em seu "paideuma", ou seja, na lista dos poetas onde seria possível vislumbrar os princípios estéticos nos quais o concretismo se baseia. Teremos a oportunidade de, no terceiro capitulo desta segunda parte, voltar a esse assunto. Por ora, basta citar uma passagem do "plano piloto para a poesia concreta", onde são listados e qualificados os "precursores" do concretismo no Brasil (que, finalmente, se reduzem, aqui, a dois, Oswald de Andrade e João Cabral):

no/brasil:/oswald de andrade (1890 - 1954) : «em comprimidos, minutos de poesia »./joão cabral de melo neto (n. 1920 - o engenheiro e psicologia da composição mais anti-ode): linguagem direta, economia e arquitetura funcional do verso203 (O grifo é nosso)

Os príncipios de "economia" dos meios e o de "arquitetura funcional do verso" são, aqui, os de verdadeiro valor poiético. Conjugados, ambos apontam para a valorização do projeto, já que para economizar é preciso bem prever, e toda função exercida é prédeterminada: deve-se saber a que devem servir os órgãos do edifício antes que este seja erguido. O concretismo, no afã de construir uma história evolutiva da literatura brasileira (cujo ponto de chegada seria justamente a poesia concreta), interessou-se fortemente pela tese de um João Cabral rigorosamente construtivista, que calculava seus poemas através de uma "matemática da composição", tal como pretendiam fazer os próprios concretos ${ }^{204}$.

203 CAMPOS, Augusto de et al. Teoria da poesia concreta. Textos críticos e manifestos, 1950 - 1960. São Paulo: Brasiliense, 1987, p. 156.

204 Lembremos que os concretistas chegaram a pensar uma poesia calculada matematicamente; ver, por exemplo, "Da fenomenologia da composição à matemática da composição", idem, ibidem. 
Mas outros críticos, fora do círculo concretista, também utilizaram a imagem da arquitetura para caracterizar o fazer cabralino, como, por exemplo, Benedito Nunes, em uma análise que faz do livro $O$ engenheiro. A análise, que supervaloriza o poema de mesmo nome, tenta mostrar que aí há um "ideal de lucidez poética", propriamente arquitetônico, como se vê nesta passagem:

A feitura do poema, que se qualifica de máquina de comover, obedecerá analogicamente à mesma razão construtiva e geométrica que gera o projeto técnico de uma máquina e a planta de um edifício, traçados a lápis e a esquadro em uma folha de papel ${ }^{205}$

Os termos são quase idênticos à passagem citada de Haroldo de Campos, como se pode ver pela referência explícita aos intrumentos do arquiteto. Aqui a arquitetura - e analogicamente a poesia - é vista como essencialmente projetual no sentido de que o "projeto técnico" concebido determina, de forma completa, os agenciamentos construtivos. Esse processo é explicitamente descrito na citação seguinte, na qual são nomeados também os valores - inspiração, acaso, sonho - que se quer negar com a adoção de tal procedimento:

A criação [é considerada, em $O$ engenheiro,] como ato de pensamento lúcido que se completa no ato de escrever, ambos dirigidos no sentido do controle racional dos efeitos poéticos contra as interferências do acaso, que a inspiração e o sonho favorecem.206

São distinguidas, nessa citação, duas fases no processo compositivo, a de concepção ("ato de pensamento lúcido"), fruto do cálculo do poeta-engenheiro e a de realização ("ato de escrever"), que ocorre na folha em branco ${ }^{207}$. Ambas as etapas são controladas

\footnotetext{
${ }^{205}$ NUNES, Benedito. João Cabral de Melo Neto. Rio de Janeiro: Vozes, 1974, p. 41.

206 Idem, ibidem, p. 42.

${ }^{207}$ Idem, ibidem.
} 
racionalmente, de maneira a assegurar que o efeitos calculados na concepção sejam idênticos aos efeitos da obra feita. A produção poética pensada por Benedito Nunes como "ato de pensamento lúcido que se completa no ato de escrver", ou seja, como projeção intencional do poema e sua execução rigorosa na folha em branco, conforme o projeto, é idêntica ao modelo eidético aristotélico exposto no $1^{\mathrm{o}}$ capítulo da $1^{\mathrm{a}}$ parte desta tese. Segundo esse modelo, no processo produtivo a concepção (noesis) é anterior e determinante com relação à realização (poiesis), na medida em que, nesse processo, há, como comenta Heidegger uma "re-presentação que vê antecipadamente o ergon em seu eidos" 208 . A lógica do processo criativo é, portanto, entendida como projeção a priori de estruturas e sentidos linguísticos, seguida de uma execução rigorosa do projetado. Essa lógica está presente em outra passagem do livro de Benedito Nunes, que comenta o livro $O$ engenheiro, onde se retoma a metáfora arquitetônica, sendo, mais uma vez, o canteiro submetido ao desenho:

o edifício, em que se resolve o sonho do poeta-engenheiro, terá nascido, antes de situar-se na natureza, sobre o papel, onde foi traçado, a lápis e a esquadro, na forma geometricamente clara de um croquis. ${ }^{209}$

O que é dito na passagem apenas repete a estrutura eidética ou arquitetônica através da qual o crítico caracteriza o fazer de João Cabral. O paradigma da arquitetura estará, tal e qual, maciçamente presente nos textos de outros críticos. Por exemplo, na apresentação escrita por Reinaldo Marques para o livro de Helton Gonçalves de Souza, A poesia crítica de João Cabral de Melo Neto, pode-se ler a seguinte afirmação:

${ }^{208}$ HEIDEGGER, Martin. Sobre a essência e a realidade da força. Petrópolis: Editora Vozes, 2007, p. 149.

${ }^{209}$ NUNES, Benedito. João Cabral de Melo Neto, op. cit. p., 41. 
é justamente contra esse fracasso [rendição às forças do acaso] de Mallarmé que se insurge, obstinado, o projeto poético de João Cabral de Melo Neto. Tarefa para a qual o poeta-engenheiro se arma de uma geometria matemático-plástica, de réguas, esquadros e cálculo. ${ }^{210}$

A passagem acima retoma quase identicamente os termos de Haroldo de Campos, já citado. A metáfora não varia: reaparecem os instrumentos e operações do arquiteto (régua, esquadro, cálculo) para a determinação do processo criativo cabralino.

Uma tese de doutorado recente sobre o fazer de João Cabral, escrita por Olivo Bedin, repete a metáfora, deixando claro que o principal valor inerente procedimento arquitetônico em Cabral é a projeção lúcida do poema:

É chamado com justiça de o "poeta-engenheiro", devido ao grau de premeditação formal empregada na produção de seus poemas, colocando palavra sobre palavra, assim como o engenheiro coloca pedra sobre pedra ${ }^{211}$.

Sob o risco de nos tornarmos enfadonhos, daremos mais dois exemplos de teses recentes sobre o poeta que retomam os termos da arquitetura como representativa do fazer poético de Cabral, atentando, no entanto, para certa relativização dessa imagem presente nas passagens. O primeiro é Waltencir Alves de Oliveira;

[Na obra de Cabral] o cálculo estrutural do engenheiro é sempre o mesmo, a matéria-prima também pode ser constante [...], assim como o modo de fazer, [...] contudo cada edifício-poema determinará como as variáveis do projeto se combinarão para modular a construção adequada $^{212}$

210 MARQUES, REINALDO, Apresentação. In: SOUZA, Helton Gonçalves de. A poesia crítica de João Cabral de Melo Neto. São Paulo: Annablume, 1999, p. 14.

211 BEDIN, Olivo, O fazer poético de João Cabral de Melo Neto e Fernando Pessoa, Tese: Literatura portuguesa: Universidade de São Paulo, 2009, p. 31.

212 OLIVEIRA, Waltencir Alves de, O gosto dos extremos. Tensão e dualidade em João Cabral de Melo Neto de Pedra do sono a Andando Sevilha. Tese: Teoria Literária e Literatura Comparada. Universidade de São Paulo, 2008, p. 186. 
Para o comentador, ainda que haja, em Cabral, a repetição do cálculo da estrutura, da matéria-prima, e do modo de fazer, a singularidade de cada um de seus poemas, fruto de uma tensão constante no poeta ("frieza geométrica" vs. "tematização da subjetividade"213), impediriam que os poemas sejam classificados univocadamente. Essa tensão constante na obra de Cabral geraria "a formulação de pares antagônicos e/ou complementares que podem atuar em um ou mais poemas, mas que não, obrigatoriamente, permitiriam distinguir longas séries a ponto de construir uma vertente" 214 . Baseia-se nisso a crítica do autor à tradicional tese que separa a obra de Cabral em "duas águas", uma metalinguística ("de concentração reflexiva") e outra mais participativa ("para auditórios mais largos").215

Uma outra estudiosa de Cabral, Thais Mitiko Taussig Toshimitsu, em sua tese de doutorado ${ }^{216}$, também relativiza a metáfora do poeta-arquiteto, ao limitar seu alcance e eficácia. Com respeito ao alcance da arquitetura cabralina, diz a autora que as "contas e as descrições matemáticas" resultantes das análises das "construções geométricas" feitas por diversos estudiosos da obra do poeta, não representam verdadeiramente "formas em si" 217. Com relação à eficácia do procedimento arquitetônico em Cabral, Thaís Toshimitsu afirma que a arquitetura de Cabral, enquanto "ordenadora do mundo do caos e da

${ }^{213}$ Idem, ibidem, p. 182.

214 Idem, ibidem, p. 184.

215 As expressões entre aspas são do próprio Cabral apud CAMPOS, Haroldo, Metalinguagem e outras metas, op. cit. p. 84. Ver também a definição de Haroldo de Campos de cada uma das "duas águas" de João Cabral: "Poesia crítica e poesia que põe o seu instrumento, passado pelo crivo dessa crítica, a serviço da comunidade", idem, ibidem, pp. $84-85$.

216 TOSHIMITSU, Thaís Mitiko Taussig, O rio, a cidade e o poeta. Impasses e contradições na poesia de João Cabral de Melo Neto. Tese: Teoria Literária e Literatura Comparada, Universidade de São Paulo, 2009.

217 Idem, ibidem. p. 184 
pobreza" 218, parece "dar a ilusão de ordem ao absurdo" 219 . O exemplo por excelência dessa contradição seria o livro A educação pela pedra, ao qual a autora se refere nestes termos:

o poeta cria padrões de organização dos poemas e das estrofes, fazendo com que o conjunto pareça organicamente coeso e coerente. No entanto, o conteúdo parece querer rebentar cada um desses limites, seja com a memória, com o passado, com a morte, ou com o imprevisível. Enfim, a realidade: do sertão, do mangue, da cidade do Recife ou de Sevilha, do canavial, do mar, do rio...220

Ou seja, o projeto arquitetônico de Cabral seria limitado, pois tentaria dar um arranjo, que, segundo a autora, é essencialmente dualista, a uma realidade que transborda tal estrutura.

O conceito principal na constituição da metáfora do poetaarquiteto ou do poeta-engenheiro é o de projeto. Foi o crítico literário João Alexandre Barbosa quem refinou de maneira mais consequente tal conceito, a ponto de considerar a unidade da obra do poeta a partir dele. Tal projeto é assim apresentado pelo crítico:

Quando se diz projeto o que se quer dizer é, sobretudo, a direção assumida por uma certa poética em relação tanto ao conjunto da literatura praticada anteriormente, ou concomitantemente, quanto em relação às soluções perseguidas pela própria obra em jogo. Dizendo de outro modo, trata-se de saber em que medida o novo código instaurado pelo poeta responde não apenas a transformações operadas sobre um código anterior quanto à formulação nova a partir de uma problematização dos dados por ele oferecidos.221

O projeto de João Cabral é inserido, pelo crítico, em dois níveis históricos: o geral (como resposta ao "conjunto da literatura praticada anteriormente", tanto brasileira quanto ocidental) e o individual, (como direcionamento das "soluções perseguidas pela própria obra em jogo").

\footnotetext{
218 Idem, ibidem.

${ }^{219}$ A expressão é de Pedro Fiori Arantes, citado por Thaís Toshimitsu, ibidem, p. 185.

220 Idem, ibidem, pp. 185 - 186.

${ }^{221}$ BARBOSA, João Alexandre. A imitação da forma, op. cit., p. 17.
} 
O projeto cabralino, de um ponto de vista do tempo histórico local, segundo João Alexandre Barbosa, seria uma resposta à poesia então produzida no Brasil, portanto à Geração de 45 (os primeiros livros de Cabral datam do início da década de 40), como se pode depreender da seguinte passagem:

Vê-se [...] como a leitura de Murilo Mendes que realizava João Cabral sugeria uma ruptura para com a atividade média do que então se realizava no momento em que publicava o seu primeiro livro, atividade em que, de acordo com Alfredo Bosi, "as imagens vêm a ser o correlato de sentimentos e, numa fase mais avançada de condensação, os símbolos vêm a ser o véu que oculta e ao mesmo tempo sugere esses mesmos sentimentos" 222

Essa influência de Murilo Mendes - e também a de Carlos Drummond de Andrade, como o crítico não deixa de mencionar ${ }^{223}$ teria levado João Cabral a uma concepção de imagem diversa da de um "correlato" dos sentimentos. Qual seria essa concepção de imagem? O próprio crítico responde:

[A imagem em Cabral] é muito menos "temática", como ocorria com os jovens poetas de então, do que um procedimento técnico, de ordem construtiva, apontando antes para o abstrato [...] do que para a mensagem. 224

Tratar-se-ia, portanto, de uma imagem "construtivista", que, segundo o crítico, caracterizaria a poesia de João Cabral como o resultado de um esforço compositivo e não como uma espontaneidade expressiva, já que a imagem é, em sua obra, de natureza plástica, e não o veículo de uma mensagem. De modo geral, e não somente com relação à poesia brasileira de meados dos anos 40, esse projeto

222 Idem, ibidem, p. 23. A citação de Alfredo Bosi, feita por João Alexandre Barbosa encontra-se em História concisa da literatura brasileira. São Paulo: Editora Cultrix, 1970, p. 518

223 Idem, ibidem, p. 22.

${ }^{224}$ Idem, ibidem, p. 22. 
construtivista é, nas palavras do próprio João Alexandre Barbosa, um "projeto de possível eliminação do lirismo" como escreverá mais tarde o crítico ${ }^{225}$. Nesse caso, lirismo é entendido como uma característica de toda poesia centrada na expressão de estados subjetivos, sejam dados emocionais conscientes, como no caso da poesia "romântica", ou inconscientes, como no caso da poesia onírica dos surrealistas; a esse lirismo sempre se associaria a atitude psicológica da espontaneidade, da inspiração, da irreflexão do ato criativo, à qual Cabral se oporia226.

No que diz respeito à constituição desse projeto construtivista na própria obra de João Cabral, encontraríamos sua primeira formulação

225 BARBOSA, João Alexandre. Alguma crítica, op. cit., p. 259.

226 O atributo "anti-lírico" - usado para caracterizar a poesia de Cabral - se deve, sobretudo, a Luiz Costa Lima (LIMA, Luiz Costa, Lira e antilira. Mário, Drummond, Cabral. Rio de Janeiro: Topbooks, 1995.), e significa que a poesia de João Cabral "não lida com estados subjetivos", que, no seu caso, "o sentimento não mais serve à palavra poética", que o poema passa a "depender menos do estado psicológico em que é concebido" (Idem, ibidem, p. 221, 223 e 224) (os grifos são nossos). No anti-lirismo se alocaria toda reação da poética cabralina à poética romântica, centrada na função emotiva e tendo como resultado ficcional os estados ou percepções particulares de um Eu que os exprime. Luiz Costa Lima, no entanto, mais tarde, irá estabelecer uma relação menos conflituosa ente o romantismo e a poesia de João Cabral (LIMA, Luiz Costa, "João Cabral: poeta crítico", in Intervenções. São Paulo: Edusp, 2002). Trata-se, nesse ensaio, de mostrar como a atitude crítica do poeta com respeito a sua própria poesia foi inaugurada pelas reflexões do primeiro romantismo alemão representado por Novalis e Schlegel.

Lembremos, porém, que o antilirismo do poeta viria a ser relativizado por Waltencir Alves de Oliveira em sua tese de doutorado (OLIVEIRA, Waltencir Alves de, $O$ gosto dos extremos. Tensão e dualidade na poesia de João Cabral de Melo Neto de Pedra do Sono a Andando Sevilha. Tese: Teoria literária e Literatura comparada: Universidade de São Paulo, 2008.), onde o autor analisa o tema do feminino e da autobiografia, intrinsecamente subjetivos, na poesia de Cabral. Segundo o pesquisador, a tematização do amor e da mulher, em Cabral, está fincada "na concretude da terra, da casa e da cidade" e está "configurada, em maior ou menor escala, em qualquer livro do poeta" (Idem, p. 102.) O "eu autobiográfico", por seu turno, na interpretação de Waltencir Alves de Oliveira, "se inscreve tanto na dimensão social e histórica como na representação de traços da história singular do poeta" (Idem, p. 19). Portanto, para o pesquisador, a onipresença do tema amoroso e o desvio subjetivo da autobiografia devem levar à conclusão que não há em Cabral um antilirismo, se isso significa exclusão do lírico-amoroso e do Eu. Há, sim, e esta é a tese, uma "redefinição do lirismo" (Idem, p. 102): a mulher amada é inscrita na "concretude da imagem", desvestindo-se da "carnadura abstrata e da aura romântica e idealizada" (Idem, p. 100), e o sujeito se descentra na medida em que sua tematização remete a uma contextualização social e histórica (Idem, ibidem). 
explícita, segundo João Alexandre Barbosa, numa fala do personagem Raimundo de Os três mal-amados (1943), como se pode ler no seguinte comentário feito pelo crítico:

[...] o que se persegue é a lucidez [...] como nesta última fala de Raimundo: "Maria era também o sistema estabelecido de antemão, o fim onde chegar. Era a lucidez, que, ela só, nos pode dar um modo novo e completo de ver uma flor, de ler um verso"

Construção, precisão, lucidez: é o projeto que se torna mais explícito com a publicação de $O$ engenheiro [...] que, embora contendo textos que o vinculam às suas origens oníricas [...], é dominado, de fato, por um estrito senso de composição que faz justiça ao título do livro.

"Construção", "precisão", "lucidez", a proposição de um

"sistema estabelecido de antemão", são os elementos do "estrito senso de composição" de Cabral, e que qualificam seu projeto, segundo João Alexandre Barbosa. Algumas análises feitas pelo crítico de poemas do livro $O$ engenheiro, detalham ainda mais essa conduta arquitetônica. Seja observado que o parti-pris analítico de João Alexandre Barbosa é, digamos, além de temático, estrutural, procedendo o autor por uma espécie de endogênese, na medida em que pensa o processo criativo de Cabral a partir da relação entre os elementos formais do poema, ou, de outra maneira, a estruturação através da estrutura ${ }^{227}$. É o que se depreende da seguinte passagem:

[...] a meu ver, nem sempre é nos textos mais explicitamente metalinguísticos (como "O poema", ou "A lição de poesia"), que, neste livro, [O engenheiro], vai encontrar-se a discussão interna do próprio processo criador poético - efetuada a partir de um ângulo em que os

\footnotetext{
227 Tal princípio analítico, pensar a estruturação a partir da estrutura final, tem limites em termos genéticos, pois deixa de lado certo aspecto do processo compositivo. $\mathrm{Na}$ maioria das vezes, a estrutura do texto final é apenas uma - a última - das diversas formas que possivelmente um texto assumiu no processo compositivo. Como saber o que ocorreu nas outras etapas? Nesse sentido, Almuth Gréssillon tem razão ao dizer que "le texte final ne relève rien de sa genèse tant que l'on ne penètre pas dans l'embrouillamini des brouillons. Il ne donne à voir l'épaisseur et la polyphonie de sa genèse, la face nocturne et les éclairs de son invention, qu'à celui qui va à la découverte des traces qui l'ont précédé." GRÉSILLLON, Almuth, La mise en oeuvre, op. cit., p. 24).
} 
elementos de realização postos em jogo revelam, desde já, e por si mesmos, o grau de lucidez atingido pelo inventor. ${ }^{228}$

Não retomaremos aqui as análises empreendidas por João Alexandre Barbosa. Basta-nos referir que seus resultados mostram que a imagem, em João Cabral, não é encontrada, sentida, dada, mas que ela é "resolvida em relação aos outros elementos que fazem parte do objeto construído" 229 Esse sentido de composição teria sido seguido à risca pelo poeta, segundo João Alexandre Barbosa, já que haveria em sua obra uma "insidiosa, persistente e vitoriosa lucidez de seu projeto" 230 , calcado na clarividência da concepção e no rigor da realização.

${ }^{228}$ BARBOSA, João Alexandre. A imitação da forma, op. cit., p. 46.

229 Idem, ibidem, p. 46.

${ }^{230}$ Idem, ibidem, p. 274. 


\section{2. A mineralização da palavra}

A imagem do fazer poético de João Cabral como um processo guiado pela lucidez (do projeto) e pelo rigor (da realização), ou seja, como uma conduta arquitetônica, vai junto com outra imagem a ela intimamente ligada. Trata-se do que Benedito Nunes e Antonio Carlos Secchin nomearam de "poética negativa" 231 ou "poesia do menos"232, ambas identificáveis com a metáfora de "mineralização da linguagem"233. A metáfora da petrificação da linguagem é, de certa forma, o complemento da metáfora do poeta-arquiteto. Nesta, está em jogo a concepção lúcida do projeto da obra; naquela, a "transformação da palavra em pedra" que torna o material linguístico propício à construção rigorosa do poema-edifício.

A poética negativa ou mineralização da palavra é definida por Benedito Nunes exatamente nestes termos:

À luz da depuração e do esvaziamento, tópicos de uma poética negativa, o que antes era resíduo, produto de criação misteriosa, transplantado à superfície mineral da folha em branco, é natureza própria das coisas - quando em estado de palavras - e das palavras quando em estado de coisas. Atinge-se na mineralização reconhecida da linguagem, que dá nova direção à vontade de petrificar, a equivalência entre imagem e palavra ou entre palavra e coisa, que é o mistério sem mistério da poesia234

Através da negatividade ou da mineralização, o ato de escrita, segundo Benedito Nunes, seria guiado, em Cabral, por uma certa

${ }^{231}$ NUNES, Benedito. João Cabral de Melo Neto, op. cit., p. 51.

${ }^{232}$ SECCHIN, Antonio Carlos. João Cabral: a poesia do menos. São Paulo: Duas Cidades, 1985.

${ }^{233}$ NUNES, Benedito. Op. cit., p. 48 e SECCHIN, Antonio Carlos, op. cit., pp. 64 -65.

${ }^{234}$ NUNES, Benedito. Op. cit., pp. $54-55$. 
teleologia de significação: a "equivalência" entre imagem e palavra, ou entre palavra e coisa. Essa mineralização da palavra, que estabiliza a significação, tornando-a unívoca, se dá por meio do processo de depuração de todo resquício subjetivo ou de ambiguidade semântica ("criação misteriosa"), até tornar a linguagem um espelho do pensamento lúcido. Isso implica ir além da expressão subjetiva, em busca de uma objetividade pura, ou, como escreve Benedito Nunes, ter um “domínio essencializado da linguagem"235.

Dominar a tal ponto a linguagem, para quê, senão para realizar de maneira mais eficaz a intenção projetiva do arquiteto? Transformar a palavra em pedra é instalá-la em uma estabilidade que a faz um objeto manipulável, cujo funcionamento é previsto e controlado. É nesse sentido que vai o comentário que faz Benedito Nunes dos versos seguintes do poema "Antiode": "Flor é a palavra/flor, verso inscrito/no verso, como as/manhãs no tempo":

Desse ponto de vista, a palavra adquire natureza entitativa dupla. Seja ela qual for, será, como centro de convergência e divergência das significações que se organizam no espaço da escrita, um objeto de percepção, comparável a uma máquina ou a um jarro de flores. Mas ela será também objeto útil, manipulável, sujeito a uma técnica, que disporá de seu funcionamento, dando-lhe serventia na máquina maior do poema, de que constitui a peça essencial. ${ }^{236}$

Muito embora a metáfora mude, e não seja, na citação acima, a palavra uma pedra, e, sim, a peça de uma máquina, permanece a ideia da instrumentalização racional da palavra, a qual, tendo controladas totalmente suas reverberações semânticas, é uma parte "manipulável" do poema-máquina (ou do poema- edifício).

235 Idem, ibidem, p. 51.

${ }^{236} \mathrm{Idem}$, ibidem, p. 60. 
Essa estabilização do material linguístico, por meio de uma depuração ou instrumentalização semântica - e que combina bem com a previsibilidade da conduta projetual - parece representar uma correspondência invariável entre o referente intencionado e o signo que o representa, se como afirma Benedito Nunes, o que se busca é a "equivalência entre imagem e palavra ou entre palavra e coisa".

O crítico Antonio Carlos Sechinn, através da imagem da "poesia do menos" defende um posição hermenêutica próxima à da "poética negativa" - ou de petrificação da palavra - proposta por Benedito Nunes. A ótica do "menos", ideia central que perpassa sua leitura da obra de Cabral, aponta para a mesma finalidade de estabilização da linguagem por meio da depuração semântica, como o próprio crítico esclarece:

Este livro [João Cabral: a poesia do menos] procura interpretar a poesia de João Cabral de Melo Neto a partir da hipótese de que ela se constrói sob o prisma do menos. Com isso, queremos dizer que os processos de formalização de seus textos são deflagrados por um ótica de desconfiança frente ao signo lingüistico, sempre visto como portador de um transbordamento de significado. Amputar do signo esse excesso é praticar o que denominamos a poesia do menos. ${ }^{237}$

O "menos", enquanto amputação do excesso semântico, lembra, de fato, a correspondência unívoca entre palavra e coisa à qual Benedito Nunes já se referia. Enquanto sinônimo de estabilidade semântica, o procedimento "menos" já estaria presente, segundo o Antonio Carlos Sechhin, no terceiro livro de João Cabral, $O$ engenheiro, através do que afirma ser "a mineralização do espaço poético" 238. Essa "mineralização do espaço poético" é legível, para o crítico, na sobreposição do elemento mineral a qualquer vitalismo, logo do "estável" ao

237 SECCHIN, Antonio Carlos. João Cabral: a poesia do menos, op. cit., p. 50.

${ }^{238}$ Idem, ibidem, p. 50 
"dinâmico", em diversos poemas do livro. Lendo o poema "Pequena ode mineral" o crítico interpreta que "o poeta, ao invés de aderir à dinâmica do natural, optou por suspendê-la."239 E finalmente, comentando o poema "A árvore", o crítico escreve o seguinte, dando uma interpretação geral do livro $O$ engenheiro:

Estabelece-se uma dicotomia entre o inanimado artificial (cimento) e o animado natural (árvore), que será, em $O$ Engenheiro, resolvida pela metáfora da pedra, que realiza a convergência entre o inanimado de um lado e o natural do outro 240

Há pois o privilégio de uma ontologia do repouso com relação a uma ontologia do movimento, na medida em que a pedra é o símbolo por excelência da estabilidade semântica buscada por João Cabral. E o que se quer com essa estabilidade pétrea? O crítico responde: “A função do estável, basicamente, é a de permitir uma lição mais precisa" 241, a lição do "menos", que representa o significado estável e exato depurado de tudo o que é excesso e significação imprevisível.

A busca por essa linguagem estabilizada seria progressiva em Cabral, afirma Antonio Carlos Secchin. Embora a "mineralização do espaço poético", já se expresse no livro $O$ engenheiro, João Cabral teria dado um passo adiante em seu livro seguinte, levando ao extremo a instrumentalização da linguagem:

João Cabral experimentará, no livro seguinte [ao O engenheiro], mover-se com a mineralização do espaço poético [...] que conferirá ao poema, antes de tudo, o estatuto de máquina"242 (o grifo é do autor).

239 Idem, ibidem, p. 49.

240 Idem, ibidem, p. 50.

241 Idem, ibidem, p. 44.

${ }^{242}$ Idem, ibidem, p. 50. 
O livro seguinte de Cabral, ao qual se refere o crítico é Psicologia da composição com a Fábula de Anfion e Antiode (1947). Através de Anfion, a personagem da "Fábula", João Cabral teria insistido, segundo a interpretação de Secchin, na estabilidade e na subtração (a poesia do "menos" semântico) como valores de base do fazer poético através da valorização da metáfora da pedra, símbolo da permanência oposto ao imprevisível do acaso e ao instável do sujeito e da linguagem.

Comentando a relação entre esses dois reinos naturais, o orgânico e o inorgânico, no inicío do poema, o crítico escreve que a pedra, privilegiada pela personagem Anfion - e, logo, por Cabral habita "um 'tempo claro', suspenso como na fábula'". Com respeito ao vegetal, afirma: “O vegetal, ao contrário, é visto como resquício de uma herança noturna [...] e, por isso, deve ser eliminado" 243.

$\mathrm{Na}$ passagem seguinte do poema, haveria, para o crítico, uma clara vinculação entre o processo de mineralização e de subtração, emblemas de uma "poética negativa" (tal como já se exprimia Benedito Nunes) que se radicaliza na medida em que a "secura" desértica, portanto mineral, também se opõe à cinesia vital do reino orgânico, seja vegetal ou animal:

A poética negativa se radicaliza porque, ao lado do elogio do vazio essa fome do nada, ou apetite do menos, de "A Paul Valéry" - se intensifica a técnica da subtração. O ciclo de expansão/reprodução é minado em todas as frentes, seja a humana, ("sua flauta seca:/como/.../lábios"), seja a animal ("não choca os velhos/ovos do mistério"), ou a vegetal ("Mesmo os esguios,/discretos trigais/não resistem")244.

243 Idem, ibidem, p. 53.

${ }^{244}$ Idem, ibidem, p. 55. 
A negação do vitalismo ocorre justamente porque ele é “imprevisível”, a ele é intrínseco o acaso, produzido pelo movimento, que Anfion - e Cabral -, através do repouso da pedra e da subtração da secura, tentam exatamente abolir. Mas, no poema, o acaso ataca e em forma vital ("Ó acaso, raro/animal") e Tebas se faz sob o signo do imprevisível. Conhece-se o gesto final de Anfion: lamentando-se, ele lança a flauta "aos peixes surdo-/mudos do mar". Segundo Antonio Carlos Secchin, a impossibilidade de suspensão do movimento (abolição do acaso), presente no final do poema, provoca um impasse, qual seja, nas palavras do crítico: “O impasse é que, perdida a flauta, renuncia-se não só a Tebas mas também à reconquista do deserto que a precedeu."245. Mas tal impasse, continua o crítico, seria resolvido pela Psicologia da composição, na medida em que, neste poema, o poeta teria conseguido dominar o acaso imprevisível "mantendo-se fiel a várias "lições" da 'Fábula de Anfion'" 246 Isso se revela na seguinte passagem, que comenta o poema sobrepondo a mineralização ao vitalismo:

A depuração do vegetal só se formaliza se admitir, pela escrita, sua passagem a uma condição também mineral: não deve vigorar como algo incontrolável, que reluta em se submeter à atenção.

A escrita em Cabral seria, assim, um processo de petrificação que faria com que a linguagem adquirisse um sentido estável, livre de variações semânticas imprevisíveis. A essa imagem de petrificação associa-se, como já dissemos acima, a do poeta-arquiteto, se se segue a intepretação da maioria dos críticos. A segunda imagem implica uma operação de projeção lúcida de estruturas e sentidos e a primeira uma operação de realização rigorosa do que foi projetado através da manipulação da linguagem, agora "transformada em pedra", ou, no

\footnotetext{
245 Idem, ibidem, p. 60.

246 Idem, ibidem.
} 
dizer de Antonio Carlos Secchin, pela "amputação" de seu "excesso" semântico. Em suma, o que se afirma, na crítica literária, como valores fundamentais do fazer cabralino é a previsibilidade da obra a fazer e a estabilidade do material linguístico.

Acreditamos, porém, que diversos textos de Cabral levam à relativização da definição do fazer como um processo inteiramente controlado. Esses textos são, por um lado, justamente aqueles nos quais a crítica literária haure as metáforas do poeta-arquiteto e da "mineralização" da palavra: o livro O engenheiro e os poemas "Fábula de Anfion" e "Psicologia da composição". Veremos que, nessas obras, as noções de imprevisibilidade e instabilidade são inerentes à representação feita por Cabral da criação literária, expressas, por exemplo, nas metáforas vitalistas utilizadas pelo poeta. Por outro lado, veremos que alguns de seus textos teóricos (Joan Miró e "Poesia e composição"), além de diversos poemas metalinguísticos, escritos em sua fase madura (principalmente a partir de Museu de tudo (1974), por meio da noção de refeitura contínua (ou de inacabamento) problematizam em seu fundamento a ideia de uma conduta arquitetônica. São esses textos que gostaríamos de analisar nos capítulos que a seguir. 


\section{Capítulo 2. Imprevisibilidade e instabilidade do fazer literário em $O$ engenheiro, "Fábula de Anfion" e "Psicologia da composição"}

\section{1. A representação do fazer em $O$ engenheiro}

Empreenderemos, neste capítulo, uma análise dos poemas metalinguísticos de $O$ engenheiro, do poema "Fábula de Anfion" e do poema "Psicologia da composição", por se tratar de textos onde, preferencialmente, a crítica literária colhe elementos para a construção da metáfora do poeta-engenheiro e da "petrificação" da linguagem.

Como vimos, essas metáforas representam a conduta criativa de João Cabral de Melo Neto através dos conceitos de pré-visão projetual e de estabilização do material linguístico. Ao propormos uma interpretação que relativiza o controle arquitetônico no processo compositivo de João Cabral, relevando zonas de imprevisibilidade, devidas ao caráter instável tanto do material linguístico quanto do próprio sujeito criador, não queremos identificar o processo compositivo cabralino com uma qualquer conduta de "expressão de sentimentos". Ao contrário: cremos que João Alexandre Barbosa tem razão ao afirmar que, já em $O$ engenheiro, existe uma sobreposição do fazer ao dizer ${ }^{247}$, o que significa que Cabral está mais interessado na

247 BARBOSA, João Alexandre, Alguma crítica, op. cit., p. 254. 
composição do poema do que na manifestação de sua interioridade. Mas esse sentido de composição não é exatamente arquitetônico, não se se pensa "arquitetônico" como um processo completamente controlado e determinado a partir de uma intenção clara (o projeto) e que permanece estável durante o processo de escrita. Uma análise dos poemas de Cabral, em que o fazer é explicitamente tematizado, nos dará meios para propor mais nitidamente a que processo de criação nos referimos.

Essa análise tentará mostrar a representação do fazer literário na poesia de João Cabral através da caracterização das cinco "áreas de instanciação" que estão na base de toda enunciação, segundo a teoria linguística de Bernard Pottier, o qual citamos:

la personne du locuteur crée l'existence (3) en relation avec les autres existences des êtres ou des choses, et donc des événements.

On remarque en outre que, dans l'ensemble des langues, les mêmes relateurs peuvent s'appliquer aux quatre domaines ou aires qui couvrent l'ensemble des possibles: $l^{\prime}$ espace (E) [...], le temps (T) [...], le notionnel $(\mathrm{N})[\ldots]$, le modal $(\mathrm{M})^{248}$.

Na teoria de Bernard Pottier, essa cinco áreas de instanciação, a existencial, a espacial, a temporal, a nocional e a modal, constituem cada um dos modelos morfodinâmicos - cronoexperiencial $^{249}$,

\footnotetext{
248 POTTIER, Bernard. Représentations mentales et catégorisations linguistiques. op. cit., p. 16. Ou ainda, conforme afirma Maria Helena Araújo Carreira: "As áreas de instanciação de uma representação [...] segundo a teorização de Bernard Pottier, em que o núcleo deíctico pode ser o EGO ou qualquer outro ponto de referência, conduzem-nos ao estudo das coordenadas de existência, de espaço, de tempo, do domínio nocional e modal". Ver CARREIRA, Maria Helena Araújo. Deixis e proxémica verbal. Percursos enunciativos e processos discursivos. Disponível em ler.letras.up.pt/uploads/ficheiros/6690.pdf.

249 "La cronoexpérience élémentaire est celle qui conduit à l'existence d'un phénomene (entité ou événement), puis à son retour à la non-existence. » (POTTIER, Bernard, Représentations mentales et catégorisations linguistiques. op. cit., p. 165.)
} 
cronoexistencial $^{250}$, cronoeventual 251 e cronodêitico ${ }^{252}$ - propostos pelo linguista em sua modelização das representações mentais. A representação do fazer, em Cabral, se faz na encruzilhada dos quatro modelos morfodinâmicos, pois a criação, enquanto relação entre um sujeito criador e uma obra que se faz, se deixa apreender como evento e como experiência, como passagem de uma virtualidade para uma realidade (cronoexistencial) e por meio da irradiação dêitica em torno do Eu. Assim, será percorrendo as áreas de instanciação dentro de uma relação intermodelar que tentaremos a análise da representação poiética nos poemas analisados.

O primeiro poema de $O$ engenheiro, por ordem de aparição, onde o fazer literário é referido de forma explícita, se intitula "As estações". Na última estrofe, lê-se:

Na fruta sobre a mesa
procuro um verso
que revele o outono;
procuro o ar
da estação; imagino
um freixo; exercito
truques, palavras
(ante a fruta madura
na beira da morte,
imóvel no tempo
que ela sonha parar).253

O Eu da enunciação é exatamente o sujeito criador, a partir do qual se determina um hic ${ }^{254}$ (ele se encontra "ante a fruta madura" que

\footnotetext{
250 « Le locuteur voit, par rapport à lui-même qui sert alors de support, comment les événements non-encore arrivés (virtuels) se produisent et passent ainsi dans la zone de ceux qui sont dèjà arrivés (realisés). » (Idem, ibidem, p. 151).

251 "Le locuteur fait le point sur la chronologie des événements » (Idem, ibidem, p. 152. 252 "Le locuteur se prend comme repère et il organise autour de lui les zones dêictiques par degrés de proximité et selon des orientations variées. C'est un modèle radiant." (Idem, ibidem, p. 153).

253 Obra completa, op. cit., p. 73.
} 
está "sobre a mesa"), e um nunc representado por meio de um presente inspectivo ("imagino um freixo", "exercito truques, palavras"). Ou seja, vemos o sujeito criador diante do poema que faz, no momento em que o faz (no puro presente da atividade de escrita).

Mas como ele faz? Três são os verbos que discriminam o procedimento do sujeito que cria, e a sequência deles pode até mesmo descrever fases do processo compositivo: ao procurar (o verso em uma fruta), segue-se o imaginar (uma árvore) e, em seguida, a tentativa de formulação linguística ("exercito truques, palavras”). Procurar, imaginar e exercitar têm bem mais a ver com uma lógica de descoberta do que com uma uma lógica de projeção. Os atos poiéticos, em sua modalidade epistêmica ("imaginar"), factual ("exercitar", "procurar") representam o fazer dentro de uma zona de virtualidade ("procurar") e de atualização ("exercitar" palavras), mas não de realização. O sujeito criador não concebe o verso, ele o procura; o factor não realiza com rigor o verso, ele experimenta de forma tateante com a linguagem. O poeta está sentado à mesa, mas ele não está concebendo o modelo (projeto) do que irá compor, nem tampouco realizando um projeto já concebido. Ao contrário, o fazer é representado como um esforço factual incerto em seu resultado. A passagem do virtual ao real do poema não está, portanto, a priori, garantida. Observe-se, ainda, que, no poema, o verso que se procura deve "revelar o outono". Portanto, o verso é a transfiguração da fruta (através da imaginação de uma árvore) em uma categoria temporal, o outono. Trata-se bem de uma transfiguração metonímica. Fazer da fruta outono é exatamente fazer o contrário do que a própria fruta sobre a mesa faz. Fazer da fruta outono, é instaurar, pela linguagem poética, o tempo. Ora, a fruta sobre a mesa quer o

254 O EGO (egologia), o HIC (topologia), o NUNC (cronologia), o SIC (noologia), o HOC (tropologia), remetem, respectivamente, a cada uma das áreas de instanciação acima referidas. Ver POTTIER, Bernard, Représentations mentales et catégorisations linguistiques, op. cit., pp. $16-17$. 
contrário, ela "sonha parar o tempo". Como natureza morta, a fruta tem a mesma qualidade da pedra, natureza sem vida, onde "nada se gasta/mas permanece" - como é afirmado no poema "Pequena ode mineral" 255 -, mas se opõe ao verso que revela a temporalidade. A fruta, objeto de observação do poeta, remete à noção de imobilidade, ao passo que o verso, resultado de sua imaginação e exercício, remete à noção de devir, ainda que seja o devir repetitivo das estações, título do poema.

O espaço do fazer (diante do papel, sobre a mesa), é recorrentemente referido em poemas de $O$ Engenheiro. Em um poema intitulado exatamente "A mesa", nesse espaço encontram-se "o jornal dobrado" (primeira estrofe), a "laranja verde" (segunda estrofe), a faca que apontou o lápis (terceira estrofe), e, finalmente, encontra-se o verso, como se lê na quarta e última estrofe que transcrevemos a seguir:

\footnotetext{
E o verso nascido de tua manhã viva, de teu sonho extinto, ainda leve, quente e fresco como pão. 256
}

Não podemos concordar com o comentário de José Guilherme Merquior que vê nessa passagem a introdução "de uma analogia entre o produto natural e o produto poético, entre o verso e o pão", e, logo, um ideal “de imitação do produzir natural" 257. Antes de tudo, é preciso dizer que se, no pão, encontram-se elementos naturais, ele, no entanto, é um produto artificial, feito a partir de uma técnica. Dito isso, a comparação entre "verso" e "pão" quer significar simplesmente que o primeiro acabou de ser escrito, e, portanto, está "fresco" tal qual um

255 Obra completa, op. cit., p. 83.

${ }^{256}$ Idem, ibidem, p. 74.

${ }^{257}$ MERQUIOR, José Guilherme. A astúcia da mímese. Rio de Janeiro: Topbooks, 1997, p. 92. 
pão que acabou de sair do forno. Ambos estão sobre a mesa, lugar onde repousam também o jornal, as frutas e os utensílios de escrita. Sobre a mesa: exatamente a área espacial do poema anteriormente analisado, "As estações". Mas diferentemente da enunciação do poema anterior, que era temporalmente inspectiva (modalizada pela incerteza do resultado), neste, a visada temporal sobre o fazer é retrospectiva: o verso já está nascido. Virtualidade no poema "As estações", o verso, em "A mesa", é já realidade. De onde nasceu o verso? Nasceu "da manhã viva/do sonho extinto". Exclui-se, dessa forma, a atmosfera onírica ("sonho extinto"), e a vigília solar ("manhã viva) torna-se a origem do poema. Temos aqui, de fato, uma das muitas provas que Cabral se afasta inequivocadamente do procedimento surrealista. Mas atentemos para o adjetivo "vivo", que qualifica "manhã". É a primeira aparição de uma noção vitalista na representação do fazer poético. Esse vitalismo permeia inteiramente os poemas metalinguísticos de $O$ engenheiro.

Representado a partir de noções vitalistas, o fazer em $O$ engenheiro se descreve como um processo de puro devir, instável e imprevisível, em oposição ao não-fazer que se determina pela noção de identidade, de estabilidade, como se pode ler no poema "A Paul Valéry", citado a seguir. Nele, o não-fazer, e, logo, seu contrário, o fazer, são determinados associando-se o primeiro à repetição do mesmo (e do nada) e a um estado psicológico específico, a tranquilidade, e o fazer, consequentemente, associado a termos contrários:

É o diabo no corpo ou o poema que me faz cuspir sobre meu não higiênico?

Doce tranqüilidade do não-fazer ; paz, equilíbrio perfeito do apetite de menos. 
Doce tranqüilidade

da estátua na praça,

entre a carne dos homens

que cresce e cria.

Doce tranqüilidade

do pensamento da pedra, sem fuga, evaporação,

febre, vertigem.

Doce tranqüilidade

do homem na praia:

o calor evapora,

a areia absorve,

as águas dissolvem

os líquidos da vida;

o vento dispersa

os sonhos, e apaga

a inaudível palavra

futura, - apenas

saída da boca,

sorvida no silêncio. ${ }^{258}$

A estas duas características psicológicas que distinguem, no poema, o fazer e não- fazer:

\section{não-fazer $=$ tranquilidade, $[$ fazer $=$ inquietude] \\ não-fazer $=$ apetite do menos, $[$ fazer $=$ apetite do mais $]$}

acrescentam-se os seguintes pares de oposições:

Não-fazer

estátua na praça [pedra]

pensamento da pedra

calor, areia, águas [do mar]

vento
Fazer

carne dos homens

/ [pensamento do homem]

/ líquidos da vida

/ Sonho, salavra

258 Obra completa, op. cit. pp. $82-83$. 
Os pares de oposições remetem o fazer e o não-fazer a duas naturezas perfeitamente distintas. O não-fazer é associado à natureza dos quatro elementos, o mineral (estátua da praça ${ }^{259}$, pensamento da pedra, areia), o aquático (águas [do mar]), o ígneo (calor) e o aéreo (vento); e o fazer está associado à natureza humana (carne dos homens, vida, sonho, palavra). Os quatro elementos, que representam o nãofazer, por sua vez, são associados:

1) à ideia de imobilismo. É o caso do elemento mineral. A estátua da praça é a mesma, diferentemente da carne dos homens, que "cresce e cria"; o pensamento da pedra permanece idêntico a si, contrariamente ao pensamento humano que se altera.

2) à ideia do nada. Os outros elementos, além do mineral, estão associados a operações negativas: o calor evapora, as águas dissolvem, o vento dispersa. E o que tanto o fogo, quanto a água e o ar nadificam é justamente o que é mutável, a vida, a criação, a palavra futura.

A noção de identidade, ligada ao não-fazer, e a noção de mudança, ligada ao fazer, são modalizadas axiologicamente na medida em que é associado ao primeiro um valor desejável (a tranquilidade) e ao segundo um valor indesejável (a inquietude). Tal modalização fez com que os críticos interpretassem o poema como uma escolha do silêncio feita pelo poeta, como se lê neste comentário de João Alexandre Barbosa:

[...] o silêncio conquistado vai ser o núcleo essencial da apreensão de Valéry ("Doce tranquilidade/do não-fazer; paz,/equilíbrio perfeito/do apetite de menos" "ou "a inaudível palavra/futura, - apenas / saída da boca,/sorvida no silêncio.")

259 Evidentemente, a estátua não é um objeto natural, mas o poema remete mais à matéria da estátua do que a ela mesma. 
[...] é antes a conquista do silêncio e do "não-fazer", do que um apetite a mais não satisfeito, para inverter os termos usados pelo escritor, $\mathrm{o}$ que se transmite. 260

Vai nesse mesmo sentido a interpretação de Antonio Carlos Secchin, segundo esta passagem:

A partir do núcleo implícito "silêncio" (o "não-fazer"), outras imagens são geradas [...] em que, por um lado, é marcada como positiva a ausência de produção discursiva (o "pensamento da pedra"), e por outro, são desvalorizados os signos que indiquem expansão e mobilidade ("carne dos homens").261

Os comentaristas calcam suas análises na modalização positiva do não-fazer ("Doce tranquilidade) e negativa do fazer ([amarga inquietude]). Assim, pelos comentários acima, o fazer seria negado e o não-fazer afirmado, como se silenciar fosse uma fase necessária do aprendizado poético, para que finalmente o poeta alcance sua própria dicção. Mas tal interpretação não se verifica com a leitura da primeira estrofe do poema:

$$
\begin{aligned}
& \text { É o diabo no corpo } \\
& \text { ou o poema } \\
& \text { que me faz cuspir } \\
& \text { sobre meu não higiênico? }
\end{aligned}
$$

Nessa estrofe a opção pelo fazer - e não pelo não-fazer - é explicitamente feita. $\mathrm{O} \mathrm{Eu}$ enunciador (que se confunde com o sujeito que cria) "cospe" sobre - quer dizer, recusa - seu "não higiênico" - quer dizer, o não-fazer. A "doce tranquilidade" do não-fazer está antes perdida que conquistada, porque o poeta, simplesmente, é aquele que faz, e o fazer é, segundo o poema, movimento e expansão do que se cria

260 BARBOSA, João Alexandre. A imitação da forma, op. cit., p. 48.

261 SECCHIN, Antonio Carlos. João Cabral: a poesia do menos, op. cit., pp. 42-43. 
e inquietude de quem cria. O não-fazer participa da mesmidade e da ataraxia; com o fazer, temos o contrário.

A pergunta feita na estrofe acima (é o "diabo no corpo ou poema/que me faz cuspir sobre meu não higiênico?"), modaliza o saber do sujeito criador com relação ao que faz, aproximando a atividade criativa mais da incerteza que da certeza no eixo da modalidade epistêmica. É ela respondida em outra parte do livro? Antes de verificálo, seja dito que, pouco importando se se trata do "diabo no corpo" ou do "poema" que leva o sujeito a criar (a "cuspir sobre seu não higiênico), a criação será sempre assumida, instável e inquieta.

A resposta à pergunta feita na primeira estrofe do poema acima talvez possa ser dada com a leitura de um texto intitulado exatamente “O poema”. A afirmação da penúltima estrofe do texto:

Mas é no papel, no branco asséptico, que o verso rebenta. 262

leva a pensar que é o poema, não o "diabo no corpo", que leva à recusa da ascese do não-fazer, que leva o poeta a sujar a folha asséptica. Assim considerado, nascido da folha branca, o poema é algo que o factor se impõe e que cultiva com esforço, não aquele que espontaneamente lhe acontece. O poema, como se vê pela forma verbal "rebenta", é mais uma vez representado vitalistamente, o que se reafirma na última estrofe do poema, na qual o verso é figurado como um ser vivo:

Como um ser vivo

pode brotar

de um chão mineral?

262 Obra completa, op. cit., p. 76. 
Porém, a noção vitalista presente nesses versos não aponta para uma espontaneidade do brotamento do poema. Porque através da contraposição do brotar a um solo que não lhe é propício, o "chão mineral", pode-se ler a passagem como uma afirmação do cultivo do - e não da espera pelo - verso. A forma interrogativa, de qualquer forma, modaliza epistemicamente o propósito do Eu enunciador (o sujeito criador), fazendo-o tender antes para a incerteza do que para a certeza sobre o processo criativo que leva do branco da página (chão mineral) ao verso (ser vivo). O início do poema propõe talvez uma resposta:

\author{
A tinta e a lápis \\ escrevem-se todos \\ os versos do mundo.
}

O enunciado parece, à primeira vista, inteiramente banal. Mas atrás dessa banalidade - se pensarmos na remissão aos instrumentos de trabalho do escritor (tinta, lápis) - está a expressão do esforço necessário que se deve fazer para romper a mineralidade da folha em branco e fazer com que nela nasça o verso ${ }^{263}$.

\footnotetext{
${ }^{263}$ A leitura de textos revelados recentemente por Flora Süssekind (SUSSEKIND, Flora (org.). Correspondência de Cabral com Bandeira e Drummond. Rio de Janeiro: Editora Nova Fronteira, 2001), pode confirmar essa interpretação. Trata-se da primeira versão do poema que estamos comentando ("O poema"), que se intitulava, então, "Lição de poesia", publicada no suplemento "Autores e livros" de 3 de outubro de 1943. Nessa versão, o poema possui uma parte a mais que citamos e comentamos a seguir: $A$ mão que escreve/É conservada em sal/Como a memória//(Lembrança da cidade/De todas as águas:/Mar, rios, pântano;//Lembrança do amor/Água de chuva, alegre/E logo morta)//Mas a mão é carne/Viva, suando:/Em sal, sua morte,//Em tinta, o impulso/De vida, rumoroso/Como na semente. A mão que escreve "sua", ou seja, ela é agente de um esforço fatigante; dessa forma, ela pode tranformar "Em tinta o impulso/De vida". O "impulso de vida" que se transforma em tinta é representado mais uma vez pela noção de natureza vital ("rumoroso como na semente"), o que confirma o procedimento do cultivo como necessário para o florescimento do poema.
} 
Podemos afirmar, assim, que, para o nascimento do verso ("ser vivo"), no chão mineral, é preciso a mão que o cultive ${ }^{264}$. O esforço de cultivar o verso é necessário por causa não somente do vazio da página branca (sua passividade estéril), que ameaça de aborto o próprio processo criativo, na medida em que a página pode permanecer branca, mas também por causa da instabilidade do verso que se escreve, ameaçado, assim, de retornar ao nada.

À primeira ordem de imprevisibilidade poiética (a passividade estéril da página branca que pode assim permanecer) se refere a primeira parte do poema "Lição de poesia", que mostra a folha em branco como sinônimo de esterilidade:

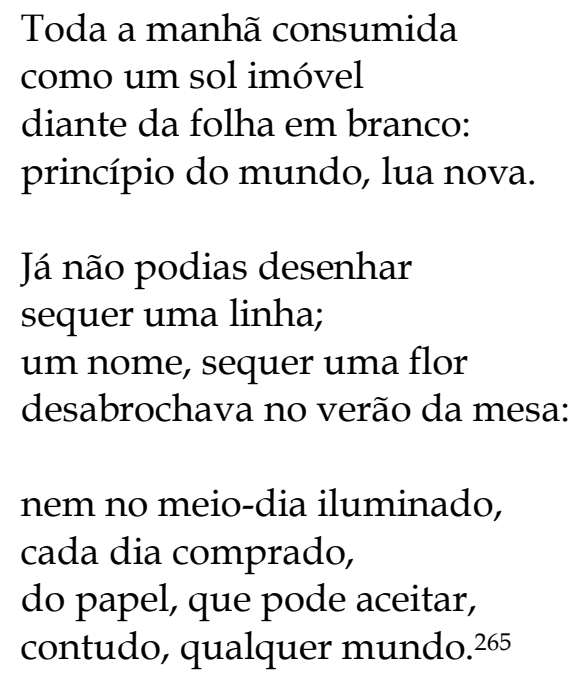

O espaço da atividade criativa continua a mesmo - "diante da folha em branco", posta sobre a mesa. Mas diferentemente do poema "As estações" - onde o verso era uma virtualidade em processo de efetuação (o poeta, procurando-o, exercitava palavras) - e difentemente, ainda, do poema "A mesa", onde o verso já era uma realidade, aqui o

${ }^{264}$ Lembre-se que em "Alguns toureiros" (Obra completa, op. cit., p. 158), o toureiro Manolete ensina ao poeta "como cultivar sua flor". E em Psicologia da composição (idem, ibidem, p. 96), o fazer é figurado com um "cultivar o deserto".

265 Obra completa, op. cit., p. 78. 
verso é simplesmente uma impossibilidade: “Já não podias desenhar/sequer um linha". Podemos, dessa forma, determinar um certo aspecto dual, contraditório, do espaço poiético da folha em branco. Primeiro, ele é o espaço de uma virtualidade efetuável e realizável, como nos poemas "As estações" e "A mesa". A página, como dirá o poeta em certo poema, é "branca de vida/ainda por nascer" 266 . Segundo, como no poema acima, o espaço poiético (a página) se associa a uma virtualidade sem realização possível, quer dizer, nele nada se pode escrever ainda que o papel em branco aceite "qualquer mundo". A visada retrospectiva ("já não podias...) reconstitui, portanto, essa situação de total esterilidade ("sequer uma linha", "sequer uma flor" se desenhava ou desabrochava no "verão da mesa"). Nocionalmente, a passagem acima determina a situação poiética dentro de um domínio idêntico ao do não-fazer e oposto ao do fazer presente no poema "A Paul Valéry" através do uso de lexemas ligados à noções do nada e do imobilismo: "Toda manhã consumida/como um sol imóvel".

A segunda parte do poema representa uma situação enunciativa diversa, onde o sujeito criador (não mais um "tu", mas um "ele", que, de qualquer forma, designa o poeta) se esforça por tentar "salvar da morte" o poema em efetuação:

A noite inteira o poeta em sua mesa, tentando salvar da morte os monstros germinados em seu tinteiro.

266 Fazemos aqui referência ao poema "O papel em branco" que João Cabral não publicou em livro (somente em jornal: A manhã, 3 de outubro de 1943), mas que Flora Sussekind trouxe a lume no anexo de sua edição da correspondência entre Cabral e Manuel Bandeira e entre Cabral e Carlos Drummond de Andrade. Nesse poema, escreve Cabral escreve o seguinte sobre a folha branca "Não é a morte/que a faz deserta;/é branca de vida/ainda por nascer" (SUSSEKIND, Flora. Correspondência de Cabral com Bandeira e Drummond, op. cit., pp. 265-268). 


\begin{abstract}
Monstros, bichos, fantasmas
de palavras, circulando

urinando sobre o papel

sujando-o com seu carvão.

Carvão de lápis, carvão

de ideia fixa, carvão

da emoção extinta, carvão

consumido nos sonhos. ${ }^{267}$
\end{abstract}

O espaço poiético continua o mesmo: o poeta está em sua mesa. O tempo, porém, é outro: a manhã, sol imóvel, associada à esterilidade da página, agora dá lugar à noite associada à precariedade das palavras. Essa precariedade do material linguístico configura, assim, a segunda ordem de imprevisibilidade poiética já apontada acima - qual seja, a possibilidade permanente do poema voltar ao vazio da página, contra a qual o sujeito criador luta. O domínio nocional no qual as palavras se determinam representa a linguagem dentro de uma área de forte instabilidade: "monstros, bichos, fantasmas de palavras" são entidades ligadas à transformação. As duas primeiras partes do poema mostram, assim, que é dupla a luta do poeta: primeiro contra a permanência do branco da folha, quer dizer, contra a esterilidade aquém do ato de escrita (o poeta em sua mesa sem poder desenhar "sequer uma linha"). Segundo, contra o retorno do poema que se faz ao silêncio da página, devido a seu caráter precário ("o poeta/em sua mesa tentando/salvar da morte os monstros/germinados em seu tinteiro").

O espaço-tempo da conduta criativa, em $O$ engenheiro, é portanto, associado a noções distintas. Por um lado, ele é pensado como pura virtualidade, sem efetuação possível, do poema. Por outro lado, é pensado como um pura efetuação, sem uma realização assegurada. Trata-se do duplo aspecto da "luta sobre o papel".

267 Obra completa, op. cit., p. 78. 
Esse duplo aspecto é retomado na terceira e última parte do poema, da qual transcrevemos três estrofes:

\begin{abstract}
A luta branca sobre o papel que o poeta evita, luta branca onde corre o sangue de suas veias de água salgada.
\end{abstract}

$\mathrm{E}$ as vinte palavras recolhidas nas águas salgadas do poeta e de que se servirá o poeta em sua máquina útil.

Vinte palavras sempre as mesmas de que conhece o funcionamento, a evaporação, a densidade menor que a do ar. 268

A ferida do poeta (suas veias estão abertas), resultante da luta contra a página, ressalta o caráter agônico da criação literária (contra o branco da página e contra a morte do poema) e o aproxima da modalidade axiológica que representa o fazer como intranquilo, logo, como sendo de uma dificuldade incontrolável, passível tanto de sucesso quanto de fracasso. A segunda estrofe do trecho transcrito acima, através de uma visada prospectiva ("as vinte palavras [...] de que se servirá o poeta), sugere o sucesso possível, a construção da "máquina útil". Mas tal sucesso é de fato somente possível, como mostra a leitura da última estrofe. Nela, as palavras tanto podem funcionar como orgãos de um poema-máquina, mas ao mesmo tempo podem evaporar-se ${ }^{269}$, quer dizer, retornar ao silêncio da página, o que reafirma a

\footnotetext{
268 Obra completa, op. cit., pp. 78-79.

${ }^{269}$ Lembre-se que a noção de evaporação representa, no poema "A Paul Valéry" ("o calor evapora [...] os líquidos da vida"), o não-fazer, portanto um estado a-poiético tal como, de certa forma, a evaporação das palavras durante o processo de composição no poema "A lição de poesia".
} 
precariedade e instabilidade do material poético. Vai nesse mesmo sentido o comentário de João Alexandre Barbosa:

"Máquina de comover", todavia, o seu [do poema] dispositivo de deflagração corre o risco de secura e do acaso - não obstante a lucidez, o jogo de inteligência que possa presidir a composição de sua engrenagem. Daí “a evaporação, a densidade/menor que a do ar"270

Ainda em outros poemas metalinguísticos de $O$ engenheiro o escrever é representado a partir de noção de instabilidade - na medida em que há sempre a possibilidade que se retorne ao "vazio" da "página branca" - modalizando-se a conduta criativa como essencialmente inquietante. É o que se lê no poema “O funcionário:" que transcrevemos parcialmente a seguir:

\footnotetext{
No papel de serviço escrevo teu nome (estranho à sala como qualquer flor) mas a borracha vem e apaga.

Apaga as letras, o carvão do lápis

impõe enfim o vazio à página branca; calma à mesa, sono ao lápis,

a mim a prosa procurada, o conforto da poesia ida.
}

A associação do apagamento das palavras com a calma, da poesia ida com o conforto, e, consequentemente, a associação do

270 BARBOSA, João Alexandre. A imitação da forma, op. cit., p. 56. 
escrever com a inquietude da mudança e do fracasso possível repetem a associação já feita, no poema "A Paul Valéry", do não-fazer com a tranquilidade e, logo, do fazer com um estado de pertubação. Esse tipo de representação do estado psicológico do sujeito criador ocorre com insistência nos poemas de $O$ engenheiro. Sob o risco de repetição, citemos ainda um outro poema. Trata-se de "A árvore", cuja segunda parte citamos a seguir:

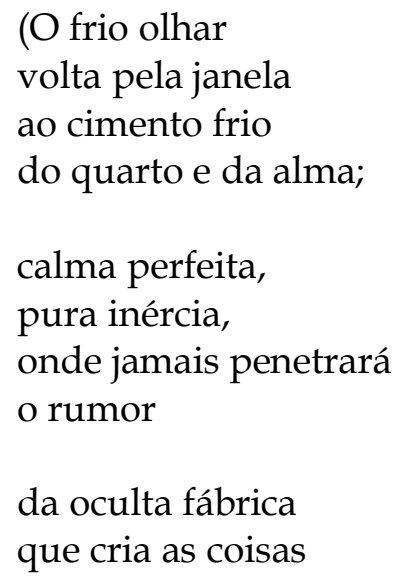

A “calma perfeita", a "pura inércia", estados psicológico e físico subsumíveis, ambos, às noções de constância e imobilidade são associados a uma situação que exclui a poiesis: o rumor da criação jamais penetrará no frio silêncio da alma petrificada. Por outro lado, a fábrica da criação é rumorosa, e, logo, associada não à perfeita calma, mas à inconstância, não à pura inércia, mas ao movimento. Qualificada também como "oculta", a criação se modaliza também como algo ignorado, não completamente permeável à lucidez controladora do trabalho calculado. 
A análise de como o processo criativo é representado na quase totalidade ${ }^{271}$ dos poemas de $O$ engenheiro, que tratam explicitamente da criação, leva-nos às seguintes conclusões:

1. O fazer literário acontece, por um lado, em um espaço poiético específico: o poeta está diante da folha, em sua mesa. Vimos que tal espaço é associado à noção de esterilidade (do poeta), já que é possível que não se logre escrever o verso, permanecendo branca a folha. E também é associado à noção de precariedade (das palavras), já que o poema que se faz está sempre sob a ameaça de retornar ao nada. Por outro lado, o fazer ocorre em uma temporalidade que indica mais o caráter virtual do poema do que sua realidade.

2. As noções ligadas à representação da criação são as de imprevisibilidade, instabilidade, esforço, precariedade, inconstância etc., se nos lembrarmos das formas verbais utilizadas nessa representação: o poeta "procura", "imagina", "exercita", "tenta salvar da morte" o poema, "não consegue escrever sequer uma linha", etc. As mesmas noções acima reaparecem quando o verso é representado por meio de uma imagem vitalista, como um "ser vivo" que nasce de um "chão mineral", e as palavras como "monstros, bichos, fantasmas". Lembre-se ainda que, de modo, geral, o fazer é representado a partir de domínio nocional do movimento e da diferença do Outro, contrariamente ao não-fazer, ligado à incércia e à repetição do Mesmo, como pudemos ler no poema "A Paul Valéry".

3. Finalmente, a conduta criativa é modalizada pelo sujeito criador como uma experiência pertubardora: doce tranquilidade do nãofazer/amarga inquietude do fazer, portanto como algo que se faz sob o

\footnotetext{
271 Excetuou-se o poema "A Carlos Drummond de Andrade", cuja primeira estrofe ("Não há guarda-chuva/contra o poema/subindo de regiões onde tudo é supresa/como uma flor mesmo num canteiro"), apenas reafirmaria o quanto o processo criativo escapa à consciência lúcida que procurasse controlá-lo completamente.
} 
signo da inscontância. A inconstância desse estado psicológico corresponde à precariedade do material poético e à qualidade virtual do poema a fazer.

Resumindo, em $O$ engenheiro, o fazer é um esforço, diante da folha em branco, de realizar um poema sempre ameaçado pelo malogro devido ao caráter precário de sua composição e ao caráter inconstante do sujeito criador.

Na medida em que João Cabral de Melo Neto nunca fez a opção pela "tranquilidade do não-fazer"272, como comprova toda a sua obra produzida depois de $O$ engenheiro, conclui-se que optou pela inquietude do fazer. Vemos essa inquietude fruto tanto dos estados variáveis do factor, quanto da realização instável do opus, presos a uma contigência que escapa à constância da pedra e à previsibilidade da técnica. Seja dito, porém, que justamente o modelo arquitetônico, com sua psicologia do controle absoluto do processo criativo através da lucidez projetiva e inspectiva, não é completamente ausente da poiética de $O$ engenheiro como o mostra o poema de mesmo nome, e a ética do poema "Pequena ode mineral", onde a pedra é representada como o modelo de ordem e de constância que se deve procurar para suplantar a "desordem da alma". O estado psicológico de calma e o processo compositivo perfeitamente ordenado seriam capazes de anular a imprevisibilidade do poema a fazer - e mesmo a esterilidade da folha branca -, através do cálculo compositivo. Mas, arriscamos dizê-lo, trata-se aí de um ideal poiético, que não corresponde à realidade da criação. Esse ideal pode ter sido desejado por Cabral, mas, como ele mesmo afirma, nunca foi alcançado e a ele o poeta renunciou. É o que lemos nesta resposta do

272 Apesar do que dizem alguns críticos citados acima (especialmente Antonio Carlos Sechhin), para quem Cabral usou "a estratégia do silêncio" no seu aprendizado poético (João Cabral: a poesia do menos, op. cit., p. 51). 
poeta dada a Clarice Lispector, que indaga se, na vida, Cabral é tão tranquilo quanto o engenheiro em que se transforma quando escreve:

[...] alguém que me visse escrever, veria que trabalhar tranquilamente como um engenheiro [de forma calculada e mais fria possível] é, em mim, uma aspiração, somente uma coisa que nunca pude alcançar e que já desisiti de alcançar. ${ }^{273}$

Acreditamos que a construção desse ideal arquitetônico de controle absoluto do processo compositivo, bem como a renúncia a ele, podem ser lidos no poema "Fábula de Anfion", que analisamos a seguir.

273 Pasta Pi. Original de entrevista dada à Manchete. 


\section{2. Projeto e realização arquitetônicos em} "Fábula de Anfion"

O poema "Fábula de Anfion" tem especial interesse aqui porque expõe, de forma aguda, a problemática relação entre projeto e realização, tendo como paradigma metafórico a arquitetura. Resumamos rapidamente o poema para em seguida empreender uma análise um pouco mais detalhada do problema.

O poema, que se divide em três partes (1. $\mathrm{O}$ deserto; 2 . $\mathrm{O}$ acaso; $\mathrm{e}$ 3. Anfion em Tebas), narra, enquanto fábula, a construção de Tebas, retomando de forma bem particular o antigo mito grego do filho de Zeus e Antíope ${ }^{274}$.

Na primeira parte ${ }^{275}$, descreve-se o lugar onde se encontra Anfion. Como uma personagem não somente mítica, mas também mística e ascética, que aspira a uma pureza extrema, Anfion "respira o deserto". Essa pureza extrema é comparável a um estado de lucidez e controle quase absolutos, e o deserto, por tudo reduzir à luz e à

\footnotetext{
274 Inúmeros comentadores não deixaram de lembrar, e de bem analisar o fato, que João Cabral remete também, por meio de sua fábula, ao melodrama de Paul Valéry, Amphion, como, por exemplo, Luiz Costa Lima e João Alexandre Barbosa. O primeiro, vê no poema de Cabral uma traição da influência do poeta francês, pois, se este "opera uma nova sacralização do poético", Cabral, por sua vez, "dessacraliza-o" e se vê diante do problema do "que fazer da poesia" (LIMA, Luiz Costa. Lira e antilira, op. cit., p. 230). João Alexandre Barbosa interpreta de forma um pouco semelhante ao afirmar que, se em Valéry a flauta de Anfion (símbolo da criação) é relacionada como o "encantamento" e o "louvor", em Cabral, ela se relaciona com a "desilusão e o silêncio". Citemos João Alexandre Barbosa: "Entre a concessão da lira a Anfion por Apolo e sua inutilidade e secura na leitura de João Cabral, a metáfora foi transformada pela escolha de uma posição que, à diferença do Amphion valeryano, recusa o próprio sentido através do qual ela surge: a relação não é mais de encantamento e louvor mas de desilusão e silêncio" (BARBOSA, João Alexandre. A imitação da forma, op. cit., p. 61.)

275 Obra completa, op. cit., pp. $87-89$.
} 
imobilidade, é propício ao alcance desse estado. Observem-se os termos que sublinhamos ligados ao deserto e que exprimem a inércia e a claridade: "isento/[...] da alada/vegetação"; "deserto/que fogem as nuvens"; "Ali, é um tempo claro"; "nada sobrou da noite"; "sem a terra doce/de água e de sono". Agora, confiram-se certas marcas do ideal de clarividência e equilíbrio buscados por Anfion: “como se preciso círculo/estivesse riscando"; "gesto puro de resíduos", "sua mudez está assegurada"; "agora que lavado/de todo canto".

A segunda parte ${ }^{276}$, intitulada "O acaso", descreve a construção de Tebas propriamente. Ao contrário da primeira parte, onde reina a mesmidade e o lúcido silêncio mineral, na parte 2 saltam aos olhos a transformação e seu ruído, por meio, sobretudo, de metáforas vitalistas. Assim, o acaso, agente fundamental na edificação da cidade, é "um inseto/vencendo o silêncio", é "força de cavalo", "vespa oculta". E o tempo já não tem a claridade estável, sem a mudança das estações, mas, no momento da construção de Tebas, o tempo se desdobra do tempo, "como uma caixa/de dentro de outra caixa".

Na terceria e última parte ${ }^{277}$, descreve-se a avaliação que Anfion faz da Tebas que construiu. O que Anfion atesta nessa avaliação é a dessemelhança entre seu desejo (seu projeto), e o que foi realizado. O "gesto puro de resíduos" cede lugar à "copada folhagem / de gestos"; o "verão", "cujas rodas [Anfion] quisera fixar", e que expressaria o "puro sol em si" de uma cidade de "liso muro, e branco", agora ilumina uma cidade impura, feita de ásperos tijolos e misturada com “a terra e a flora".

Como narração da construção de Tebas, "Fábula de Anfion" é um mito arquitetônico-urbanístico. Essa interpretação já fora avançada

276 Idem, ibidem, pp. $89-90$.
277 Idem, ibidem, pp. $90-92$. 
pelo poeta Eucanaã Ferraz em seu ensaio “Anfion, arquiteto" 278. Para o autor do ensaio, na "Fábula de Anfion" João Cabral teria retomado o ideal estético presente no poema "O engenheiro", onde o poeta "já se servira do edifício racionalista para definir os próprios instrumentos de trabalho"279. A "fábula" enfatizaria ainda mais a centralidade do "racionalismo arquitetônico" como princípio ético e formal em Cabral. Nas palavras de Eucanaã Ferraz:

o poeta [João Cabral] encontrou no racionalismo arquitetônico a proposição ética e formal capaz de renovar o verso e garantir o conteúdo social do poema ${ }^{280}$

Mas o que é esse racionalismo arquitetônico, e quais esses príncipios éticos e formais? Trata-se, como afirma o poeta português, da razão projetiva-construtiva, a que concebe a obra em sua perfeição, a cidade ou o poesia "justa", isenta de qualquer obscuridade, leve e transparente. Esse ideal anfiônico de previsibilidade e controle é aproximado, por Eucanaã Ferraz, do príncipio construtivo da arquitetura moderna, legível, por exemplo, na Carta de Atenas, escrita e divulgada pelo CIAM (Congresso Internacional de Arquitetura Moderna, de 1933), que citamos conforme Eucanaã Ferraz:

A cidade adquirirá o caráter de uma empresa estudada de antemão e submetida ao rigor de um planeamento geral. Sábias previsões terão esboçado o seu futuro, descrito o seu caráter, previsto a amplitude dos seus desenvolvimentos e limitado, previamente, o seu excesso. [...] A cidade não será mais o resultado desordenado de iniciativas acidentais. ${ }^{281}$

\footnotetext{
278 FERRAZ, Eucanaã. Anfion, arquiteto. Colóquio-Letras. Paisagem tipográfica. Homenagem a João Cabral de Melo Neto, n’s 157/158, julho/dezembro 2000, pp. 81 - 98.

${ }^{279}$ Idem, ibidem, p. 82.

280 Idem, ibidem, p. 96.

281 apud FERRAZ, Eucanaã, ibidem, p. 96.
} 
Se o poema é um fábula arquitetônico-urbanística, representando a concepção construtivista da arquitetura moderna, seria possível fazer corresponder cada uma de suas partes a três fases do processo de produção arquitetônica ${ }^{282}$.

A primeira parte de "Fábula de Anfion", intitulada "O deserto" seria o lugar da virtualidade do projeto $^{283}$, do desenho da cidade por vir, traçado com plena lucidez e fixado em sua forma perfeita. De fato, algumas passagens, notadas também por Eucanaã Ferraz, autorizam essa interpretação. São antecipadas, aí, de certa forma, as linhas da cidade, por meio de uma linguagem geométrica :

No deserto

Anfion, como se preciso círculo estivesse riscando

na areia. 284

E é também antecipado o material com o qual a cidade deverá ser erguida:

282 José Guilherme Merquior fala dos três tempos da "história" narrada pela fábula: " $1^{\circ}$ - antes da criação de Tebas; $2^{\circ}$ - Criação de Tebas; $3^{\circ}$ - Após a criação de Tebas" (MERQUIOR, José Guilherme, A astúcia da mímese (ensaios sobre lírica). Rio de Janeiro: Topbooks, 1997, p. 119).

${ }^{283} \mathrm{O}$ deserto é interpretado, por Othon Moacir Garcia, como metáfora da página branca. Cf. A página branca e o deserto (Revista do livro, ns 7, 8, 9 e 10, 1958 apud MERQUIOR, José Guilherme, ibidem.

284 Eucanaã Ferraz comenta que a imagem do "círculo preciso", no poema, se não representa rigorosamente um projeto, "seria mais que uma imagem abstrata, o símbolo de uma totalidade incorpórea, ou seja, algo como uma intenção plástica, em que se anunciam certos valores expressos pela geometria" ("Anfion, arquiteto, art. cit., p. 90). Sabemos, por meio de Sérgio Ferro, que um dos momentos principais, na história da arquitetura, da separação entre o desenho e o canteiro, se dá com a instituição de um conjunto de métodos que permitem construir desenhos geométricos, sistematizado pela Géométrie descriptive (1799) de Gaspard Monge. Ver FERRO, Sérgio, Arquitetura e trabalho livre, op. cit., p. 158. 
será de mudo cimento

não será um búzio

a concha que é o resto

de dia de seu dia. ${ }^{285}$

Se a parte "O deserto" corresponderia ao momento do desenho arquitetônico, a parte "O acaso", corresponderia ao momento da realização da cidade, ao canteiro de obras. Essa caracterização é legível no poema. Em "O deserto" havia o "gesto puro de resíduos" do arquiteto que traça seu plano. Em "O acaso" há a representação da enorme energia física dispensada pelo corpo operário para a edificação da cidade. Daí a referência ao acaso como "força/de cavalo", como "um camelo [que] sobrevive à sede". Daí a substituição da "mão escassa" de Anfion arquiteto, árida "do exercíco/puro do nada" (na medida em que é só pensamento), pelas "mãos frutíferas", pela "copada folhagem de gestos" 286 que se vê em Tebas em construção, e que podem muito bem lembrar os gestos do pedreiros ocupados com suas funções no erguimento da obra.

Findo o trabalho de edificação, a terceira parte encena Anfion diante da obra, avaliando-a. A avaliação é negativa. Em uma triste visada retrospectiva, diz Anfion;

\footnotetext{
"Esta cidade, Tebas, não a quisera assim de tijolos plantada, que a terra e a flora procuram reaver a sua origem menor:

como já distinguir onde começa a hera, a argila, ou a terra acaba?
}

285 Obra completa, op. cit., p. 89.

${ }^{286}$ Ver $3^{\mathrm{a}}$ parte do poema, p. 91. 
Desejei longamente

liso muro, e branco,

puro sol em si

como qualquer laranja;

leve laje sonhei

largada no espaço.

Onde a cidade

volante, a nuvem

civil sonhada?" 287

Em sua retrospecção Anfion constata a dessemelhança entre o que projetara e o que foi realizado. A sua fala lamenta, como escreve João Alexandre Barbosa, “a distância insuperável entre intenção e objetivação" 288. Mas o que constitui a dessemelhança entre o desenho do arquiteto Anfion e a produção do canteiro de Tebas? Segundo Eucanaã Ferraz, trata-se de uma “oposição entre duas linguagens construtivas"289, especificamente arquitetônicas. Citando Kenneth Frampton (que por sua vez remete a Gottfried Semper), o autor as designa uma como tectônica e outra como estereotômica. Ambas são assim qualificadas pelo crítico com os seguintes termos:

[Na] tectônica da armação [...] peças de comprimento variado são articuladas para circundar um campo espacial; a estereotomia da massa compressiva [...] embora possa corporificar o espaço, é construída por meio do empilhamento de unidades idênticas [...] isto é, [...] a armação tende no sentido do aéreo e da desmaterialização, enquanto a massa tende no sentido do telúrico; uma pressupondo a luz, a outra, a escuridão. 290

Essa diferença entre a "linguagem tectônica" do projeto de Anfion e a "linguagem estereotômica" do canteiro de Tebas aponta para

\footnotetext{
287 Obra completa, op. cit., pp. 91 - 92.

288 BARBOSA, João Alexandre. A imitação da forma, op. cit., p. 68.

289 FERRAZ, Eucanaã, art. cit. p. 88.

290 apud FERRAZ, Eucanaã, ibidem, pp, 92 - 93.
} 
uma diferença fundamental entre a forma e o material prescritos pelo desenho e a forma e o material da realização da cidade. A diferença está em que Anfion planejara uma cidade aérea, construída a partir de cima, do ar ("cidade volante/nuvem civil"), feita de "liso muro" e "leve laje":
Desejei longamente
liso muro, e branco,
leve laje sonhei
largada no espaço. ${ }^{291}$

Mas o resultado foi uma construção não aérea, mas térrea, que se agarra ao chão; não uma cidade de leves lajes e lisos muros, mas feita de rugosos tijolos, de vermelha argila:

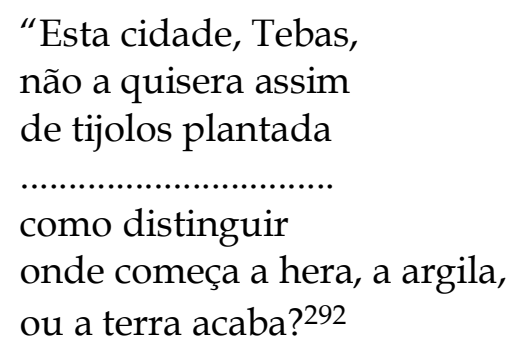

Eucanaã Ferraz interpreta a diferença hierarquicamente: haveria uma superioridade do projeto de Anfion com relação ao resultado obtido. Essa superioridade se traduziria pela filiação moderna do desenho anfiônico (“Quando Anfion fala [...] sua utopia [...] é descrita por imagens que legendam poeticamente as formas e o conteúdo utópico da arquitectura moderna"293) em contraposição ao caráter tradicional da cidade que foi erguida.

Mas Anfion fracassa. $\mathrm{O}$ fracasso de Anfion não é tão grave assim para Eucanaã Ferraz: o arquiteto, verificando a assimetria entre projeto

291 Obra completa, op. cit., p. 91.

292 Idem, ibidem, p. 91

${ }^{293}$ FERRAZ, Eucanaã. Anfion, arquiteto, art. cit., p. 91. 
e realização, joga fora sua flauta ("A flauta, eu a joguei/aos peixes surdos-/mudos do mar"), mas, ao fazê-lo, na verdade teria lançado ao mar a "falha"294 de seu empreendimento, pronto para uma nova tentativa.

Mas como Anfion pôde fracassar? Não seria justamente por ter caído na ilusão da pré-visão projetual de toda a obra, independente do canteiro, de ter por demais se fiado nas promessa de perfeição de um desenho separado? Uma certa arrogância arquitetônica está na base de sua falha. Essa arrogância Sérgio Ferro a denuncia nos casos mais emblemáticos da modernidade arquitetônica. Seria o caso, por exemplo, de Le Corbusier e seu convento de La Tourette. Na concepção dessa obra, Le Corbusier seguia príncipios idênticos ao de Anfion arquiteto (o caráter "volante" da construção), como se pode ler nessa passagem do arquiteto de origem suiça onde comenta seu próprio projeto:

Aqui, nesse terreno, que era tão móvel, tão fugidio, descendo, escorregando, eu disse: não vou tomar por base a terra porque ela escapa. Tomemos por base, no alto, a horizontal do prédio no topo, mediremos todas as coisas a partir daí e atingiremos o chão no momento em que o tocarmos. ${ }^{295}$

O comentário que Sérgio Ferro faz desse fala de Le Corbusier é preciso, como se lê nesta passagem:

Curiosa posição para um "construtor": partir do teto. A edificação real, coitada, tem sempre que sair do chão. O oxímoro, o teto é a base, anuncia o quiasmo das relações entre o desenho e o canteiro: lá, o andamento vai da ficção à construção, aqui, da construção à ficção. Quase todos os comentaristas do convento o olham assim, de cima para baixo, pondo de cara a construção real de lado. 296

O caso de Le Corbusier, tal como mostrado por Ferro, é semelhante ao de Anfion, ou seja, há um desequilíbrio entre a estrutura

294 Idem, ibidem, p. 97.

295 apud FERRO, Sérgio. Arquitetura e trabalho livre, op. cit, p. 220.

296 Idem, ibidem. 
fictícia, desenhada, e estrutura real, realizada. Anfion concebe uma cidade nas nuvens (assim como Le Corbusier concebeu seu convento para ser construído a partir do teto), mas os homens constroem as suas plantando-as na terra. Há mais, com respeito a Le Corbusier. Segundo Sérgio Ferro, o convento de La Tourette dá a impressão de "corresponder a uma lógica forte, bem pensada e segura de si" 297, isto é, dá a impressão que foi realizado conforme as prescrições precisas de sua concepção. Nada disso. Tal como o de Anfion, o projeto de Le Corbusier era irrealizável e teve que se render às evidências do canteiro. É Sérgio Ferro quem o afirma:

O que parece bem pensado frequentemente é obra do acaso. Algumas vigas e as lajes do "piano" e da sacristia, perfuradas por "canhões de luz" (no "piano") e por "metralhadoras de luz" (na sacristia) [...] eram irrealizáveis. O que é surpreendente da parte de um "construtor". Às pressas foi convocada uma empresa de construção de pontes, que resolveu o impasse recorrendo ao concreto pretendido - numa de suas primeiras aplicações em edifício na França, solução cara e então insegura. E o fruto do acaso [...] foi apresentado pelo mestre como contribuição ao avanço tecnológico. ${ }^{298}$

O fato de Le Corbusier inventar uma retórica de perfeição do projeto e de sua preexcelência com relação ao canteiro, e seus acasos, não é repetido por Anfion. Ao contrário, comove sua sinceridade constatando seu fracasso de não ter conseguido bem projetar o que deveria ser feito e tudo controlar durante o processo de edificação:

Como antecipar a árvore de som de tal semente?

${ }^{297}$ Idem, ibidem, p. 215.

298 Idem, ibidem, p. 216. 
Uma flauta: como prever

suas modulações,

cavalo solto que é louco. ${ }^{299}$

O fazer imprevisível humilha a intenção despótica ${ }^{300}$. E é humilhado, ferido em sua ascética lucidez, que Anfion lança sua flauta aos peixes. Assim renunciar à flauta não é simplesmente, pensamos, "atirar ao mar a falha", como afirma Eucanaã Ferraz, mas talvez atirar ao mar a própria tentativa de um procedimento que sobrepõe o desenho e subestima o canteiro. Não dizemos que Anfion desiste da Cidade justa, mas que desiste da Cidade que existe somente na virtualidade do projeto. Para que chegue à realização, o desenho dessa Cidade, apesar de querer permanecer o mesmo, tem de ser ajustado ou, muitas vezes, completamente transformado nos trabalhos do canteiro.

Podemos retomar diferentemente, agora, a metáfora do poetaarquiteto consagrada pela crítica literária. Como vimos, ela representa um fazer controlado que realiza rigorosamente um projeto préconcebido. Porém, na medida em que, como vimos, a imprevisibilidade e a instabilidade são, em Cabral inerentes ao processo criativo, se guardarmos a metáfora arquitetônica, preferimos representar o fazer cabralino não por meio de uma po(i)ética do projeto, como prefere João Alexandre Barbosa, mas a partir de uma po(i)ética do canteiro. Isso significa dizer que o desenho deixa de prescrever a obra completamente (como bem queria, tendo fracassado, Anfion), que ele deixa para trás seu "autoritarismo" (a expressão é de Sérgio Ferro ${ }^{301}$ ) e se rende, finalmente, à evidência de que é o canteiro o lugar onde, afinal, tudo se

\footnotetext{
299 Obras completas, p. 92.

300 Semelhantemente ao que já afirmou Michel Guérin ao discorrer sobre o fenômeno de criação: "l'imprévu humilie peut-être l'idée naïve de l'intention, en tant qu'évoluant, du début à la fin de l'acte, dans le milieu maîtrisé de la transparence" (GUÉRIN, Michel. L'artiste ou la toute-puissance des idées. Provence: Publications de l'Université de Provence, 2007, p. 72.)

301 Arquitetura e trabalho livre, op. cit., p. 429.
} 
resolve (ou não). Ou seja, que é a suja página da construção do poema onde o homem investe a energia de seu corpo-próprio na difícil tarefa de materializar sua intenção e de transformá-la, e até mesmo perdê-la durante o processo - o espaço específico e efetivo do criar literário. A arquitetura cabralina, se arquitetura há, seria, dessa forma, próxima daquela que expõe Sérgio Ferro nos seguintes termos:

[...] na arte, a concepção é pouca se isolada - como dizia Mallarmé a Degas que, apesar de ter muitas ideias, não conseguia escrever um soneto. O desenho só conta quando se perde na matéria e volta outro, transformado pelo trabalho que o redescobre transubstanciado. ${ }^{302}$

É esse movimento de ir e vir do desenho (da intenção) quando encontra a matéria (a linguagem), que o faz transformar-se (ou mesmo ser abolido, trocado por outro), desviando-se de si mesmo, ou sendo retificado, que gostaríamos de reter para caracterizar o processo criativo de João Cabral.

302 Idem, ibidem. 


\section{3. Sujeito criador e obra em processo no poema "Psicologia da composição"}

Vimos nos dois subcapítulos anteriores que as metáforas vitalistas (entre outros aspectos) dos poemas metalinguísticos de $O$ engenheiro, e a problematização da relação entre desenho e canteiro na "Fábula de Anfion", implicavam uma relativização da previsibilidade e da estabilidade da conduta arquitetônica. Em "Psicologia da composição", as coisas não são diferentes. O imprevisível e o instável são tematizados nesse poema a partir da relação entre factor e opus (em processo de instauração), como o próprio título já o indica: sendo psicologia, o sujeito criador é centralmente visado pelo poema, e sendo psicologia da composição, ele é representado em plena atividade de criar. Ou seja, trata-se aqui da psicologia do sujeito criador em sua relação com a obra que faz. Não podemos concordar, portanto, com João Alexandre Barbosa quando afirma:

Na verdade sendo uma "psicologia da composição", e não do poeta, é a persona, em que se transforma o poema, que permite as afirmações em primeira pessoa que o texto encerra. ${ }^{303}$

Ao dizer que o Eu do texto é o da persona em que o poema se transforma, o crítico entende "composição" como designando o objeto resultante da conduta criativa, que seria, assim, personificado e dissecado pelo texto. Preferimos, porém, ler o termo “composição" como designando a atividade de compor. Enquanto atividade criativa, a

303 BARBOSA, João Alexandre, A imitação da forma, pp. 71 - 72. 
composição implica necessariamente um sujeito criador - do qual se faz justamente, no poema, a psicologia - às voltas com o processo de instauração do poema. Teremos oportunidade de tratar mais detalhadamente do sentido do termo composição como designando uma atividade e não um objeto no capítulo seguinte ${ }^{304}$.

Por ora, observe-se que o começo do poema representa o Eu, que designa o sujeito que cria, diante da obra terminada, numa visada retrospectiva, tal como Anfion na terceira parte da "Fábula". Mas diferentemente deste, que se lamenta diante da cidade imperfeita (porque não conforme ao desenho que projetara), o factor, na "Psicologia da composição", descreve o processo, - entre controlado e imprevisível - que o levou à realização do poema:

Saio do meu poema como quem lava as mãos.

Algumas conchas tornaram-se que o sol da atenção cristalizou; alguma palavra que desabrochei, como a um pássaro. ${ }^{305}$

Já a ambiguidade do sintagma "lavar as mãos" mostra o duplo aspecto de finalização do processo compositivo, pois tanto pode significar o esforço do trabalho de composição (o poeta lava as mãos

304 Uma palavra sobre a estrutura compositiva do poema "Psicologia da composição". Diferentemente de "Fábula de Anfion", onde as partes estavam coesas por um núcleo narrativo comum, a construção de Tebas, não podendo ser lidas separadamente, sob o risco de perda de sentido (se se desconhecem as outras partes), "Psicologia da composição" se constitui de partes independentes entre si, justapostas, podendo ser lidas, sem prejuízo, em separado. Essa independência se confirma se notarmos que, por exemplo, o poema $\mathrm{n}^{\mathrm{o}} 2$ não era originalmente destinado a ser parte da "Psicologia da composição". Tratava-se, na verdade, de um poema autônomo, intitulado 'O papel em branco", publicado em 3/10/1943, no jornal A Manhã, poema que João Cabral reformula, e inclui, posteriormente, como uma parte de "Psicologia da composição". Ver SUSSEKÏND, Flora (org.), Correspondência de Cabral com Bandeira e Drummond, op. cit., p. 265. Assim, se um poeta-engenheiro o projetou, transformou o desenho durante os trabalhos do canteiro.

305 Obra completa, op. cit., p. 93. 
que sujou trabalhando o poema), como também um gesto de renúncia ou abandono da obra (como se o poeta desistisse de continuar o trabalho, mesmo que esse pudesse continuar). A visada retrospectiva recupera o processo criativo a partir de duas operações distintas, metaforicamente expressas, na segunda estrofe, ao mesmo tempo pela "mineralização" e pelo "desabrochamento". Mais uma vez misturam-se os reinos naturais na descrição do fazer. O poema foi, a um tempo, feito pela lucidamente controlada mineralização de algumas palavras ("conchas"), e pela surpreendente eclosão ("desabrochamento") de outras. Assim, a primeira parte de "Psicologia da composição" mostra o caráter híbrido da conduta criativa, em que concorrem controle e surpresa, domínio sobre a linguagem e manifestação inesperada do sentido. 306

Pensamos que esse caráter híbrido do fazer, entre controle e surpresa, previsibilidade e imprevisibilidade, é repetidamente refletido pelo poema. Para mostrá-lo, façamos uma leitura conjunta das duas partes seguintes (2 e 3), pois ambas têm o mesmo objeto, o papel onde se escreve, estando este ainda branco na parte 2, e já sujo pela escrita na parte 3.

Na parte 2 o poeta está diante da folha branca, ou seja, na pura virtualidade do poema (diversamente da primeira parte quando estava diante da obra realizada):

Esta folha branca me proscreve o sonho me incita ao verso nítido e preciso. ${ }^{307}$

\footnotetext{
306 João Alexandre Barbosa interpreta diferentemente (assim como Antonio Carlos Secchin) a primeira parte do poema. Para Barbosa, tanto o operação de mineralização quanto a de desabrochamento (que no entanto são nocionalmente opostas) seriam controladas pela atenção: "O pássaro em que desabrocha a palavra [...] somente agora é possível, depois da experiência calcinante e calcinada pela atenção". (BARBOSA, João Alexandre, A imitação da forma, op. cit., p. 73).

307 Obra completa, op. cit., p. 93.
} 
A página em branco aqui guarda sua face negativa e positiva ${ }^{308}$ : ela proscreve o sonho e incita ao verso nítido. Abolindo o sonho, ela é (tal como o deserto de Anfion) o lugar de uma lucidez solar, de um estado de vigília. E açulando o poeta à palavra precisa, ela é índice de uma finalidade estética, que renega o obscuro e o vago e busca a clareza e a exatidão. Mas ainda que a folha branca concite a um certo fim, o processo até ele não está de antemão garantido. É o que se pode ler na parte seguinte (3) onde se retoma o tema da página, não branca, mas "suja", daquela que é suporte do processo já começado de composição, ${ }^{309}$ representando-a novamente por meio da negatividade que, dessa vez, ameaça o próprio êxito da conduta:

Neste papel
pode teu sal
virar cinza
pode o limão
virar pedra;
o sol da pele,
o trigo do corpo
virar cinza. ${ }^{310}$

A modalidade do possível, associada à noção de transformação da vida em morte ("o trigo do corpo/virar cinza"), representam a instabilidade própria do processo compositivo. Já em “Lição de poesia”, de $O$ engenheiro, víamos o poeta diante do papel "tentando salvar da morte" suas palavras. Aqui também, a cinza, em que podem se

${ }^{308}$ Essa dupla face do papel em branco já se constatava em $O$ engenheiro. Porém, neste livro, a face negativa correspondia ao caráter infecundo da folha, ao fato de representar a impossibilidade de criar o que quer que seja.

309 Antonio Carlos Secchin nota perspicazmente que "a parte III focaliza outro momento do processo criador: nem a folha branca (II), nem a obra concluída (I), mas o salto de um a outro, e as metamorfoses que podem intervir no intervalo entre ambos.". Se bem entendemos, para o crítico, a parte III representa o processo do fazer em sua duração. (SECCHIN, Antonio Carlos, João Cabral : a poesia do menos, op. cit., p. 62.).

310 Obra completa, op. cit., p. 94. 
transformar o sal e o trigo, representa a ameaça de retorno do poema ao nada. A que se deve esse fim possível? A resposta talvez esteja na sequência do texto:

(Teme, por isso, a jovem manhã sobre as flores da véspera $)^{311}$

$\mathrm{Ou}$ seja, aquilo que se escreveu na véspera ("flores desabrochadas") pode se revelar nulo quando, na manhã seguinte, se retoma o trabalho de composição. ${ }^{312}$. O que se criou em um certo momento corre sempre o risco de "virar cinza" em outro momento do processo criativo. Ao mesmo tempo, o retornar constantemente ao trabalho de escrita, o reformular continuamente, é essencial se se recusa a execução apressada, ou de outra forma, a revelação das "flores do poema" só é possível através de uma suspensão momentânea do trabalho e de sua retomada posterior. É o que se lê na seguinte passagem:

\author{
Neste papel \\ logo fenecem \\ todas as fluídas \\ flores da pressa;
}

311 Idem, ibidem.

312 Antonio Carlos Secchin, diferentemente de nós, lê as transformações (sal, trigo, limão em cinza e pedra) como fruto do acaso, mas de um acaso "dominado". Citemos o crítico: "Embora temida, a ação do acaso é equacionada e resolvida na própria produção textual [...]. O acaso, uma vez incorporado, passará pelo mesmo crivo de depuração a que todos os elementos (e não somente os oníricos) se devem submeter". (SECCHIN, Antonio Carlos, João Cabral: a poesia do menos, op. cit., p. 62). Mas se é a "jovem manhã/sobre as flores/da véspera" a causa das transformações aniquilantes durante o processo de composição, é difícil aqui identificá-la com o acaso. Porque em Cabral, "manhã" é antes símbolo de um controle lúcido do que de uma eventualidade causal. Lembremos os versos de "A mesa": "E o verso nascido/de tua manhã viva,/de teu sonho extinto" (Obra completa, op. cit., p. 74). 
(Espera, por isso,

que a jovem manhã

te venha revelar

as flores da véspera.) $)^{313}$

Nas três primeiras partes do poema "Psicologia da composição", o fazer é representando por meio de um domínio nocional híbrido, que mescla controle e instabilidade. Na primeira, a visada retrospectiva do processo compositivo atesta o que foi resultado da cristalização pela atenção (controle) e o que foi fruto do desabrochar, retomando-se uma noção vitalista que, em Cabral, se associa ao imprevisível. Na segunda, representa-se o sujeito criador diante da folha ainda branca, sendo tal espaço negativo (com relação ao conteúdo onírico), e positivo, como lugar de uma prospeção do verso a fazer ("nítido e preciso"). E, finalmente, na terceira, representa-se o sujeito criador diante da obra que já foi iniciada e que ele retoma; essa reescrita ("a jovem manhã sobre as flores da véspera"), ao mesmo tempo em que é exigida para a obtenção do verso sem restos oníricos, pode pôr em xeque a obra que se efetua ("pode teu sal virar cinza").

Na quarta parte, o estado de coisas é semelhante. A instabilidade do processo é exposta explicitamente, seja da perspectiva do poema que se faz, que ameaça romper a forma que tenta lhe impor o sujeito que cria, seja do ponto de vista do próprio sujeito criador, cujos estados psicológicos são variáveis, indo da atenção ao descuido:

O poema, com seu cavalos, quer explodir teu tempo claro; romper seu branco fio, seu cimento mudo e fresco.

(O descuido ficara aberto de par em par; um sonho passou, deixando, fiapos, logo árvores instantâneas coagulando a preguiça.) ${ }^{314}$

313 Obra completa, op. cit., p. 94. 
A relação dessa passagem com “Fábula de Anfion” é notável e já fora explicitada por João Alexandre Barbosa. Afirma o crítico:

No poema [...] recorre [a] imagem equestre que já estava na descrição do acaso [em "Fábula de Anfion"]. Não só ela, está claro. Quer o tempo, quer o cimento "mudo e fresco", com que sonhara a construção dos muros de sua "cidade volante", ressurgem no poema. ${ }^{315}$

E poderíamos acrescentar, também, que o "descuido aberto" guarda relação com a "alva distração" de Anfion ${ }^{316}$, em cujas dobras se esconde o acaso. Assim, tal como na "Fábula", onde, apesar do "mudo cimento" prescrito, a cidade se faz de "tijolos", e onde, apesar de sua lucidez ascética, o acaso surpreende surgindo das "dobras" da distração, aqui também o cimento está sob o risco de ser rompido, surpreendemente, pelos "cavalos" do poema, e o processo compositivo ameçado pela instabilidade psicológica do sujeito criador.

Dessa forma, vemos que, se por um lado, a obra por fazer reserva sempre suas surpresas, o próprio sujeito criador, por outro, é representado a partir da variação de seus estados, que pode interferir drasticamente no processo. É uma imagem similar a proposta na $6^{\mathrm{a}}$ parte do poema:

Não a forma encontrada

mas a forma atingida como a ponta do novelo que a atenção, lenta, desenrola, aranha; como o mais extremo desse fio frágil, que se rompe ao peso, sempre, das mãos enormes.

314 Idem, ibidem, pp. 94 -95.

315 BARBOSA, João Alexandre, A imitação da forma, op. cit., p. 76.

316 Obra completa, op. cit., p. 90. 
Observa-se que há uma desproporção entre a leveza do "fio" da "forma" que a atenção "desenrola" (tal como uma "aranha") e o peso das "mãos" do poeta, responsáveis pela realização material do poema ${ }^{317}$, de tal maneira que estas rompem aquele, fazendo-se perder o que o puro pensamento lúcido havia concebido e cuja realização queria controlar. ${ }^{318}$ Não seria, aqui, retomado mais uma vez o descompasso, já tematizado em “Fábula de Anfion”, entre a que se produz no espírito e o que se realiza na matéria?

Por fim, na última seção, o cultivo do deserto "como um pomar às avessas" 319 , enquanto metáfora do processo de criação, guarda, mais uma vez uma dupla face, entre estabilidade e instabilidade. De um lado, o cultivo do deserto significa um trabalho demorado e reiterado de composição:

\section{A atenção destila palavras maduras. ${ }^{320}$}

Por outro lado, esse mesmo cultivo do deserto pode implicar não uma "destilação", ou seja, uma evaporação que condensa as palavras, fazendo com que pinguem puras no papel, mas o contrário, uma evaporação que dispersa o material linguístico, fazendo-o desaparecer, o que significa o retorno ao vazio da página em branco.

\footnotetext{
317 Basta relembrar o início do texto: "Saio do meu poema/como quem lava as mãos". 318 Antonio Carlos Secchin não deixou de notar o risco que corre a forma quando em processo de realização pelas mãos do poeta. Citemos: "'Na última estrofe, "aranha", imagem da "atenção", corrobora o ideal de controle, ao mesmo tempo em que sublinha um risco. Mãos enormes: a intromissão dos excessos do sujeito; a imprevisibilidade da matéria viva." (SECCHIN, Antonio Carlos, João Cabral: a poesia do menos, op. cit., p. 64.)

319 Os versos iniciais da última parte "Cultivar o deserto/como um pomar às avessas", retomam, uma vez mais, termos da "Fábula de Anfion". A diferença entre um poema e outro porém existe e é bem comentada por João Alexandre Barbosa: "Na inversão está a caracterização daquilo que se pretende comunicar: não mais o silêncio paralisante para o qual apontava a desilusão de Anfion ante os muros por ele construídos em torno de Tebas, mas um deserto pelo qual seja possível ler um pomar." (BARBOSA, João Alexandre, A imitação da forma, op. cit., p. 79.)

320 Obra completa, op. cit., p. 79.
} 
Então, nada mais

destila; evapora;

onde foi maça,

resta uma fome;

Onde foi palavra

resta a severa

forma do vazio.

Esta interpretação se diferencia da de Antonio Carlos Sechhin que não distingue destilação e evaporação, reduzindo ambas ao processo de lúcido e controlado "esvaziamento" semântico que caracterizaria o procedimento cabralino. Citemos o crítico:

O final do texto ["Psicologia da composição"] explora, mais um vez, o tema do esvaziamento atingido pela depuração.

A depuração do vegetal só se formaliza se admitir, pela escrita, sua passagem a uma condição também mineral: não deve vigorar como algo incontrolável, que reluta em se submeter à atenção. 321

De nossa parte, porém, pela análise da representação que a "Psicologia da composição" faz do sujeito criador em relação com a obra que faz (ou fez), preferimos não ver o processo de criação de uma forma tão limpa, de redução controlada ao essencial (depuração) - ou, como afirma o crítico, como uma "mineralização". Pois, tal como a lemos, o fazer na "Psicologia da composição" se representa sempre por dois domínios nocionais opostos, havendo variação de jugo de um sobre o outro e, mesmo, por vezes, concomitância. Lembremos alguns de tais pares: "cristalização" e "desabrochamento" ( $1^{\text {a }}$ parte); a folha branca que "incita ao verso nítido" ( $2^{\mathrm{a}}$ parte), ao passo que nesta mesma página, o "trigo" vira "cinza" ( $3^{\text {a }}$ parte); o rompante dos "cavalos" do poema contra o "cimento" que lhe impõe o sujeito que cria ( $4^{\mathrm{a}}$ parte); o

321 SECCHIN, Antonio Carlos, João Cabral: a poesia do menos, op. cit., p. 66. 
"fio" da forma, inventada pelo espírito, que se rompe sob o "peso" das "mãos" que realizam o poema ( $6^{\mathrm{a}}$ parte); a destilação que condensa, e a evaporação que dissipa as palavras ( $8^{\mathrm{a}}$ parte). Essa dualidade tensional impede a caracterização do fazer como um processo inteiramente controlado.

Essa dualidade pode levar ao uso de uma outra metáfora, que não a arquitetônica, para a representação do fazer cabralino: a da tauromaquia $^{322}$. Pois, por diversas vezes, Cabral fez referência ao fazer - e os pares opostos de "Psicologia da composição" são um exemplo disso - como um esforço por domar uma grande força, representando-a vitalistamente como "cavalo", "touro", "potro". Relembremos algumas passagens da "Psicologia da composição":

O poema, com seu cavalos, quer explodir teu tempo claro; romper seu branco fio, seu cimento mudo e fresco.

Ou ainda: (potros ou touros
contidos)

palavra

Os exemplos mais evidentes desse tipo de representação são os poemas que tematizam a "arte" de tourear, aproximando-a do fazer literário. É o caso, por exemplo, do poema "Alguns toureiros", do qual citamos as três estrofes finais:

322 O que será brevemente desenvolvido a seguir sobre a "literatura como tauromaquia" (conforme a expressão de Michel Leiris - La literatura considerada como una tauromaquia. Barcelona: Tusquets Editor, 1975) retoma as discussões levadas a cabo no curso "Estudo Analítico da Poesia de João Cabral de Melo Neto", decorrido no primeiro semestre de 2009, na Universidade de São Paulo, e ministrado pelo professor Ariovaldo José Vidal, a quem devemos a sugestão. 


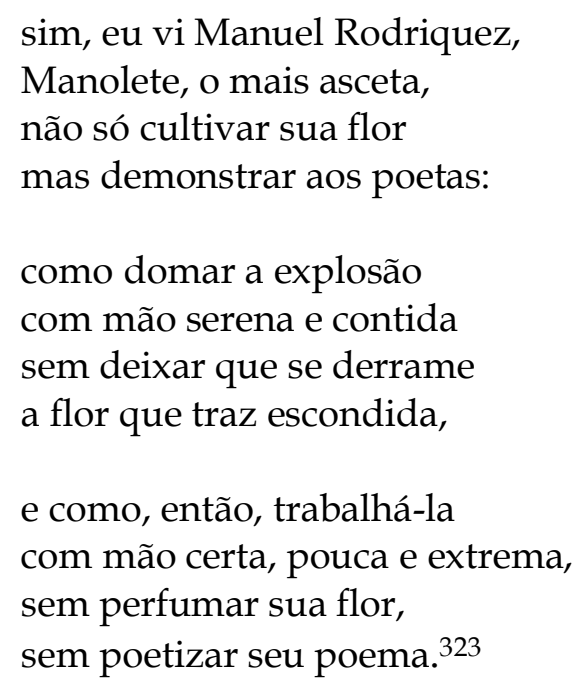

Mas se o gesto preciso do toureiro é exemplo para o poeta, na arte de tourear há um risco que também deve servir de exemplo. Esse risco é o da morte. Manolete, objeto do trecho logo acima citado, é, nesse caso, paradigmático, pois morreu toureando. A morte, aliás, de Manolete tocou profundamente Cabral, e a ela o poeta fez referência numa carta a Manuel Bandeira de 4 de setembro de 1947:

Faz hoje uma semana que um miúra matou Manolete, considerado o melhor toureiro que já aparecera até hoje - Seja dito de passagem que era um camarada fabuloso: vi-o algumas vezes em Barcelona e imaginei que era Paul Valéry toureando. ${ }^{324}$

Em outros textos, João Cabral não deixa de notar esse risco que que corre o toureiro no exercício de sua arte, já que quando toureia o faz "no extremo do ser,/no limite entre a vida e a morte" 325 . Há assim na arte de tourear o gesto preciso e o perigo de perder a vida; que tal gesto, por mais preciso que seja, não consegue evitar (e, mesmo, quanto

\footnotetext{
323 Obra completa, op. cit., p. 158.

${ }^{324}$ Ver SUSSEKÏND, Flora, Correspondência de Cabral com Bandeira e Drummond, op. cit., p. 34.

325 Versos do poema "Manolo González", Obra completa, op. cit., p. 671.
} 
mais preciso, aproxima o toureiro do risco mortal). É o que se lê nos versos finais do poema "A morte de 'Gallito'":

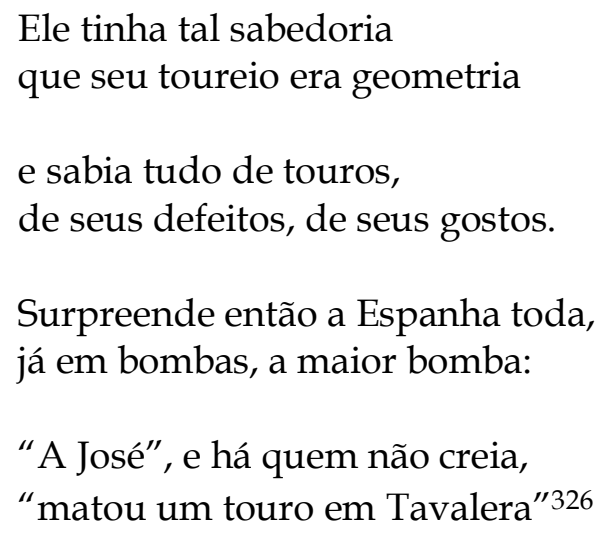

Esses dois elementos da arte do toureiro, a precisão regrada e o perigo da morte, são exatamente os que são postos em destaque por Michel Leiris na comparação que faz da tauromaquia com a arte de escrever, afirmando que o perigo é tanto maior à proporção que se busca a aplicação exata da regra:

Para este último [lo torero], es evidente que la regla, lejos de ser una protección, contribuye a ponerle en peligro: asestar la estocada en las condiciones requeridas implica, por ejemplo, que expone su cuerpo, durante un tiempo considerable, al alcance de los cuernos; existe, pues, ahí una unión inmediata entre la obediencia a la regla e al peligro corrido. ${ }^{327}$

No caso do fazer literário, não há exatamente o espetáculo da morte (tanto do touro quanto do toureiro) que a tourada nos oferece. Há aí, porém, o que poderíamos chamar de tauromaquia íntima. Michel Leiris, referindo-se a seu próprio exemplo, afirma que essa tourada solitária é a tentativa de se equilibrar entre a regra de "decir toda la

\footnotetext{
326 Idem, ibidem, p. 625.

${ }^{327}$ LEIRIS, Michel. La literatura considerada como una tauromaquia, op. cit., p. 21.
} 
verdad y nada más que la verdad ${ }^{328 "}$ e o perigo de "desacreditarse socialmente"329, já que o texto em questão são suas confissões (publicadas sob o título L'âge de l'homme) que se querem autênticas, mas, ao mesmo tempo, para chegar a tanto, implicam pessoas próximas que podem se feridas e impelidas a atacar a veracidade do relato do autor. Quer dizer, quanto mais o autor se aproxima da precisão da veracidade, mais próximo está de sua "morte social". No caso de Cabral a regra é o controle absoluto do fazer literário contra uma variabilidade intrínseca ao sujeito criador e à matéria linguística, de tal maneira que se encontra sempre sob o risco (efetivo) de ver seu "mudo cimento" rompido pelos "loucos cavalos" do poema. Os outros pares de opostos que estão na base da representação poiética de "Psicologia da composição" também exemplificam essa tensão entre regra e risco.

Acreditamos que a poesia-canteiro, tratada no subcapítulo anterior, e a poesia-tauromaquia, que acabamos de tematizar, são mais precisas para a representação do fazer cabralino que a poesiaarquitetura, pois incluem tanto a previsibilidade e o controle, quanto o imprevisível e o instável. Outras representações menos metafóricas da arte poética, presentes na obra de Cabral, vão no mesmo sentido. No capítulo seguinte trataremos dessas representações ao explorar o conceito de reescrita incessante, através do qual será afirmada, de maneira inequívoca, a incerteza essencial ao fazer literatura.

328 Idem, ibidem, p. 21.

${ }^{329}$ Idem, ibidem, p. 22. 


\section{Capítulo 3. A reescrita contínua}

\section{1. O "gosto pelo fazer"}

Nos dois capítulos anteriores desta parte vimos que ao lado de um ideal de conduta criativa (o "poeta arquiteto"), que representa de um completo controle do processo criativo, há, na obra de João Cabral de Melo, uma representação do fazer que inclui nele o imprevisível e o instável e que reclama um esforço transtornante e nem sempre eficaz para a sua "per-feição". O espaço da página branca, com seu estatuto ambíguo - ao mesmo tempo imagem do nada e solo onde o verso aparece e se transforma -, o domínio nocional vitalista com que João Cabral representa a criação, e, finalmente, a modalização do processo criativo como intranquilo, (a desordem ou "torta visão da alma" no "estertor de criar", como dirá João Cabral em poema de Museu de $\left.t u d o^{330}\right)$, mostram um fazer poético bem diverso daquele no qual a página branca é o espaço de uma antecipação projetual da obra, constituindo-se, assim, uma conduta caracterizada pela previsibilidade, pela constância e pela tranquilidade. Nesse sentido, tanto a imagem de um processo onde o canteiro é sobreposto ao projeto, quanto a de uma tauromaquia, em que concorrem regra e risco, seriam mais convenientes para figurar o fazer cabralino.

Neste terceiro capítulo, gostaríamos de aprofundar o tema da imprevisibilidade e da instabilidade do processo criativo através de

\footnotetext{
330 No poema "Exceção: Bernanos, que se dizia escritor de sala de jantar", Obra completa, op. cit., p. 413. Citamos a estrofe do poema à qual pertencem os versos referidos: "Escrever é estar no extremo/de si mesmo, e quem está/assim se exercendo nessa/nudez, a mais nua que há,/tem pudor de que outros vejam/o que deve haver de esgar,/de tiques, de gestos falhos,/de pouco espetacular/na torta visão de uma alma/no pleno estertor de criar."
} 
alguns textos teóricos do poeta sobre a atividade compositiva, bem como de alguns poemas, publicados a partir de Museu de tudo, nos quais tal tema frequentemente ocorre. Veremos que, em tais textos, o fazer é sobretudo um re-fazer indefinido, e que tal indefinição se deve a seu caráter ateleológico, quer dizer, para negar o desejo de Raimundo de Os três-mal amados, está ausente qualquer "sistema estabelecido de antemão" que determine a priori a forma final da obra por vir.

O primeiro texto no qual João Cabral considera largamente o conceito de composição é seu célebre pequeno ensaio Joan Miró331. A bem dizer, neste texto, o termo composição não é definido, mas seu sentido é pressuposto. Ele se refere tanto ao objeto resultante da ação de compor, ou melhor, a relação entre as partes e o todo desse objeto, quanto à ação mesma de composição, ou seja, de dispor as diversas partes de uma obra. Sublinhamos ação para enfatizar que João Cabral não trata somente dos quadros de Miró, mas também e, sobretudo, de sua conduta criativa. Quando Cabral escreve que o pintor "dispõe sobre a tela os elementos de suas obras", é nesse sentido, sobretudo, que entendemos, aqui, composição. Somente assim, aliás, a expressão "psicologia da composição", que aparece mais de uma vez no texto, faz sentido, quer

\footnotetext{
331 Obra completa, op. cit., pp. 690 - 720. O que segue sobre o ensaio de Cabral sobre Joan Miró não tem como objetivo uma possível e fascinante comparação entre seus poemas e os quadros do pintor catalão. Tal já foi feito Rubens Edson Alves Pereira em sua tese de doutorado, João Cabral e Miró: imanência do traço, transcendência da pedra. Tese: Literaturas de língua portuguesa: PUC/Rio de Janeiro, 1999. Em sua tese, Rubens Edson Alves Pereira apresenta as semelhanças existentes entre os "fundamentos estético-filosóficos e formas de percepção e de composição" de João Cabral e Miró. Tanto em um quanto em outro o autor vê, no que diz respeito à forma de composição, a sobreposição "da disciplina funcional herdada de uma geometria cubista ao livre curso da percepção surrealista." Esse traço abstrato, contudo, afirma ainda Rubens Pereira, não renuncia aos "substratos concretos da representação", que configuram, justamente, a "transcendência da pedra". (p. 221). Sobre a relação, ainda, entre os poemas Cabral e as pinturas de Miró, ver também GONÇALVES, Aguinaldo. Miró/João Cabral: da tela ao texto. São Paulo: Iluminuras, 1989.
} 
dizer, na medida em que é psicologia do sujeito criador no ato de criar, não psicologia do "quadro acabado".

No ensaio sobre o pintor, João Cabral determina a composição de Joan Miró, sua atividade de invenção e disposição de elementos pictóricos, a partir de seu contraste com a composição renascentista. Esta é, nos seguintes termos, caracterizada por João Cabral:

A busca de equilíbrio é [...] subjacente a todas as leis que constituem o bem compor renascentista.

Equilíbrio signfica estabilidade obtida por meio de uma correlativa distribuição de forças. ${ }^{332}$

A distribuição, efetuada pelo pintor renascentista, da força exercida por cada uma das partes do quadro segue o princípio de uma ordem total baseada na ilusão de profundidade, terceira dimensão inventada pela Renascença, conforme Cabral. Ao comparar o compor Renascentista com a prática pictórica anterior ${ }^{333}$ o poeta afirma que, se antes, na pintura das cavernas ou mesmo nas composições chapadas da assim chamada Idade Média, o objeto pintado estava solto no espaço, agora, na Renascença ele ocupa um lugar fixo, devido ao privilégio de um ponto ideal necessário para que o espectador apreenda o conjunto da obra. Assim, o compor renascentista tem sua especificidade no uso da superfície como lugar de fixação de uma ordem estática das partes da pintura, em prol da ilusão da profundidade. Essa ilusão, dirá João Cabral, é obtida pelo pintor na medida em que ele segue as “convenções lógicas" da prática de disposição da época, e essa mesma ilusão será percebida pelo espectador somente se este também seguir uma convenção de posicionamento que, tal como a ordem das partes do quadro renascentista, é estático. Citemos Cabral:

332 Idem, ibidem, p. 693.

333 Idem, ibidem, p. 691. 
Da mesma maneira que é a contemplação estática, instantânea, a convenção a que se submete o contemplador desta pintura, é o estatismo, nascido daquela convenção, o que se poderia chamar seu estilo, o espírito de sua organização. [...]

Esse estatismo, imposto pela presença e pelos interesses da terceira dimensão [a profundidade], define a pintura renanscentista, que é (ao menos a chamamos), hoje, a Pintura. ${ }^{334}$

Qual a resposta de Joan Miró a esse paradigma baseado sobre uma disposição e uma contemplação estáticas? Segundo João Cabral, em um primeiro momento, tratar-se-á, no caso de Miró, de estabelecer uma nova relação entre "objeto e moldura", abandonando-se o "ponto focal" da pintura renascentista. Nesta, o trabalho do pintor seria um movimento pictórico que vai dos limites do quadro (de sua moldura) até um ponto focal principal, tendo como contraparte o movimento inverso da contemplação "que se concentra nesse ponto focal já estabelecido e se vai diluindo até a beira da superfície pintada" 335 . Abandonando, portanto, em um primeiro momento, esse ponto de centralização como medida, Miró teria, se não ainda inventado um dinamismo (que acabaria por inventar), oposto ao estatismo da pintura renascentista, teria ao menos descoberto o que João Cabral chama de uma certa "forma de energia". Nas palavras do poeta:

Nessa época, ainda distante do dinamismo posterior, o que Miró explora não é um ato temporal do espectador. É mais bem uma forma de energia, até então não descoberta: a que pode advir da colocação de um figura numa posição tal, dentro da superfície, que produz no espectador uma sensação de que ela vai se precipitar, mudar de lugar ${ }^{336}$

\footnotetext{
334 Obra completa, op. cit., pp. 693-694.

335 Idem, ibidem, p. 698.

336 Idem, ibidem.
} 
Essa forma de energia, provinda de uma certa colocação da figura na tela, que faz com que esta tenha um movimento próprio, é, porém, segundo Cabral, tão "ilusória" quanto a profundidade da pintura da Renascença ${ }^{337}$. Isso acontece na medida em que tal forma de energia somente seria perceptível para o olho acostumado ao posicionamento do foco central. Ou seja, para Cabral, Miró, nessas pinturas que se situam no ano de 1939, subverte a Pintura estática dentro de suas convenções.

Mas, em um segundo momento, conforme ainda João Cabral, Joan Miró radicalizará sua conduta pictórica, libertando-se completamente da moldura, com a "exploração - e a consolidação - das possibilidades da superfície"338. Essa exploração apenas foi possível, continua o texto, pela revalorização do poder linha, que liberou as figuras do estatismo próprio da cor, valorizada na Renascença, e que, consequentemente, também liberou a contemplação da posição imóvel que ocupava, fazendo, agora, com que se desloque. Portanto, a grande novidade da linha, em Miró, se dá pelo fato de não obedecer a nenhuma convenção anterior, dando a aparência de que cria a si própria instantaneamente no quadro contemplado, provocando um forte sentimento de surpresa. Nas palavras de João Cabral:

[...]suas linhas [de Miró] aparecem com uma liberdade de destinação que nosso olho desconhecia.

Sua linha [...] se vai estabelecendo à medida que a contemplais. Vosso olho não pode prever, absolutamente, a seguinte direção de qualquer desses organismos. Eles parecem recomeçar a cada momento um novo caminho. Parecem burlar-se de vossos olhos automatizados, parecem interessados em livrar-se do caminho fatal que vosso olho automatizado, ou vossa mão automatizada de pintor deseja para eles, ao qual deseja condená-los. ${ }^{339}$.

337 Idem, ibidem, p. 699.

338 Idem, ibidem, p. 702.

339 Idem, ibidem, p. 705. 
Assim, no primeiro momento de sua inovação pictórica, quando abandona o ponto focal, carregando a figura com uma energia de movimento, Joan Miró havia conseguido somente uma ilusão de dinamismo. Porém, num segundo momento, segundo João Cabral, com a exploração da linha dentro de um espaço de liberdade maior, soltando-a, o pintor espanhol logra um dinamismo perfeitamente real, na medida em que corresponde a uma "sensação que pode ser verificada" 340 .

Tanto o abandono do ponto focal, quanto a exploração da linha solta somente foram possíveis, e essa é a tese de Cabral que nos interessa mais de perto aqui, devido ao fato de Joan Miró ter assumido uma atitude psicológica diferente das dos pintores renascentistas. A explicação dessa atitude psicológica torna-se fundamental para a compreensão da inovação mironiana, conforme as palavras do poeta:

Miró parte, portanto, de uma atitude psicológica. Se conseguirmos entendê-la, teremos, a meu ver, a explicação de sua originalidade em relação à pintura posterior ao Renascimento. ${ }^{341}$

Qual a psicologia da composição renascentista e posterior a ela, e qual a psicologia mironiana que a elas se opõe? A atitude psicológica dos pintores da Renascença estava intrinsecamente ligada, segundo Cabral, a um comportamento de reatualização de um sistema préestabelecido de convenções. Exceto pelos primeiros pintores do Renascimento, diz o poeta, que eram obrigados a inventar soluções para problemas que lhes eram postos - e "o mínimo detalhe de sua composição significava problema" 342 - os outros que se lhe seguem não

\footnotetext{
340 Idem, ibidem, p. 703.

341 Idem, ibidem, p. 711.

342 Idem, ibidem, p. 707.
} 
mais pesquisavam, mas aplicavam regras. É o que se depreende da seguinte passagem:

O trabalho de criação era reduzido, da pesquisa de uma solução conveniente, para a aplicação do que se sabe ser a soluçao conveniente. A lei desintelectualizava o trabalho de criação, já que foi formulada para que esse trabalho não tivesse de se repetir sempre. ${ }^{343}$

Ocorreu, então, como afirma o autor, uma automatização do gesto na composição renascentista, não somente entendida como "repetição das maneiras de fazer" - o gesto costumeiro da mão -, mas também como "automatização da sensibilidade" - a visualidade habitual ao olho. O trabalho criativo de Joan Miró distingue-se justamente por se firmar em uma atitude psicológica que nega tal automatização, uma atitude psicológica que reinventa, na liberdade, o gesto e o olho naturalizados pelo procedimento compositivo renascentista que estabelecia a priori um espaço (o estático) e uma relação (o equilíbrio) para os elementos pictóricos. João Cabral o diz explicitamente, quando caracteriza a psicologia da composição mironiana:

Ela [o obra de Miró] me parece nascer da luta permanente, no trabalho do pintor, para limpar seu olho do visto e sua mão do automático. Para colocar-se numa situação de pureza e liberdade diante do hábito e da habilidade. ${ }^{344}$

Essa atitude psicológica de Miró, que é um esforço de desabituação em relação a procedimentos naturalizados, se apóia em um valor tornado central, o gosto pelo fazer, como afirma ainda João Cabral de Melo Neto em outra passagem do texto:

\footnotetext{
343 Idem, ibidem.

${ }^{344}$ Idem, ibidem, p. 711.
} 
Em Miró, mais do que em nenhum outro artista, vejo uma enorme valorização do fazer. Pode-se dizer que, enquanto noutros o fazer é um meio para chegar a um quadro, para realizar a expressão de coisas anteriores e estranhas a esse mesmo realizar, o quadro, para Miró, é um pretexto para o fazer. Miró não pinta quadros. Miró pinta. 345

A atitude psicológica de Miró, quer dizer, o negar a repetição do hábito visual e gestual e o afirmar a diferença de um gesto e um olho livres, é calcada, portanto, na posição de um valor, o fazer pelo fazer. Esse fazer intransitivo ${ }^{346}$ valoriza a efetuação indefinida, o "inacabamento perpétuo" e não a realização completa, teleologicamente guiada, da obra. Ele, assim, esvazia o trabalho pictórico de uma finalidade objetual pré-determinada, diferentemente da prática compositiva da Renascença, onde o paradigma de um quadro estático e equilibrado a ser realizado funcionava como norma. Na verdade, o pintar intransitivo de Miró implica uma maior radicalidade: toda e qualquer norma anterior é suprimida em prol de uma liberdade absoluta. Em Miró, não há, segundo Cabral, nenhuma "exigência de uma substância cristalizada anteriormente", não existe nenhum sistema estabelecido de antemão que implicaria um problema e uma resposta pictórica já dados e apenas reatualizados no ato de pintar. É o que se lê na seguinte passagem:

No trabalho de Miró, [...] [uma] norma fixa de julgamento não existe. Nada existe exterior à sua atividade. Nada a que ele confie seu problema permanente, nenhuma fórmula à qual ele deixe a missão de buscar tal solução, com a qual ele compara sua criação. ${ }^{347}$

\footnotetext{
${ }^{345}$ Idem, ibidem, p. 711.

346 É preciso distinguir o fazer pictórico intransitivo de Miró ('Miró não pinta quadros. Miró pinta") da poesia intransitiva de René Char ("Anti-char" in Obra completa, op. cit., p. 397). Na primeira trata-se de caracterizar a conduta do pintor espanhol como um fazer que tem como finalidade produzir estendendo ao máximo o processo compositivo. No segundo, trata-se de uma qualidade semântica da poesia de René Char: sua poesia "não diz a coisa, diz vazio;/nem diz coisas, é balbucio." Quer dizer, nem define as coisas, nem as descreve: é intransitiva.

347 Idem, ibidem, p. 715.
} 
Miró trabalha assim como um pintor despido de todo hábito, de toda norma, de todo projeto ou plano de obra pré-concebido. Pintar, para Miró, segundo os termos cabralinos, é "inventar a pintura" e isso a cada instante de criação ${ }^{348}$.

O estado psicológico preponderante dessa atitude, afirma ainda João Cabral, é o de lucidez, entendida como "um estado de julgamento permanente" 349 . Mas tal julgamento não é a avaliação do resultado em sua conformidade ou não com uma determinação anterior, quer dizer, a comparação do realizado com a norma ou lei prescribente. Em Miró, escreve Cabral, cada gesto é já um resultado ("cada milímetro de linha tem de ser avaliado" ${ }^{350}$ ), e a lucidez do julgamento e o rigor da execução incidem sobre cada momento do trabalho considerado por si só a fim de assegurar-lhe a liberdade de invenção.

No fim de seu ensaio, Cabral, por sugestão do próprio Miró, faz uso da noção vitalista por excelência para caracterizar o trabalho do pintor catalão: a noção do vivo. Tal noção, segundo Cabral, "indica bem o que busca sua [de Miró] sensibilidade, e por ela, sua pintura" 351 (p. 718). O objeto dessa busca, o autor o explicita ligando-o a um espaçotempo completamente permeado pela imprevisibilidade, pela instabilidade e pelo esforço permanente de assegurar a criação sem amarras. Trata-se da "descoberta de um território livre", assim caracterizado pelo autor:

[um] território livre, onde a vida é instável e difícil, onde o direito de permanecer um minuto tem de ser duramente conseguido e essa permanência continuamente assegurada. ${ }^{352}$

\footnotetext{
348 Idem, ibidem p. 717.

349 Idem, ibidem, p. 716

350 Idem, ibidem, p. 717.

351 Idem, ibidem, p. 718.

352 Idem, ibidem.
} 
Vimos, portanto, que dois tipos de trabalho criativo são caracterizados no ensaio sobre Miró, ou melhor, dois tipos de atitudes psicológicas. Primeiro, a renascentista, caracterizada por uma maneira habitual do fazer, guiado por sistema normativo anterior e cujo resultado se avalia a partir de sua correspondência ou não com o que foi normatizado. Segundo, a mironiana, que caracteriza um fazer despido de toda pré-determinação e cujos resultados são avalidos em si mesmos, conforme seu grau de liberdade. No primeiro, o fazer é teleológico, já que tem como fim a atualização do paradigma dado pela lei, seguindo-se um trajeto já conhecido. No segundo, o fazer é ilimitado, repetindo-se (na medida em que produz diferenças) continuamente, em direção a um não-sabido, a um resultado inédito e sempre provisório. 


\section{2. A ausência de regras compositivas e o inacabamento da obra}

O ensaio "Poesia e composição" (1952), por sua vez, trata da composição, não pictórica, como no ensaio sobre Joan Miró, mas poética, como o próprio título informa. Na medida em que não é definido, o conceito de composição nesse texto, tal como no ensaio sobre Miró, é pressuposto, significando o ato de inventar e dispor várias partes em um todo, numa palavra, fazer. O objetivo principal do texto é determinar as atitudes psicológicas próprias ao trabalho de criação poética, que o autor classifica em dois tipos, o trabalho inspirado e o trabalho de arte.

Antes de abordar, detidamente, as diferenças entre as duas famílias de poetas, João Cabral considera o que há de comum em ambas: o individualismo ${ }^{353}$. O individualismo é, na verdade, um sintoma da condição histórica dos poetas contemporâneos ao ensaio de João Cabral, escrito em 1952. Nessa condição, há uma dissociação entre criação poética e valores artísticos sociabilizados, valores, no entanto,

353 Abel Barros Baptista, em seu ensaio "O cânone como formação: a teoria da literatura brasileira de Antonio Candido" (in O livro agreste. Campinas: Editora da Unicamp, 2005), dá o devido valor a esse individualismo sob uma perspectiva diferente da nossa. O autor reflete sobre o quanto tal posição individualista contrasta com a ideia de constituição de uma literatura propriamente brasileira, na medida em que apenas um conjunto de poéticas individuais não basta para constituir uma "sensibilidade mais geral", e na medida em que o imperativo poiético de tal posição é a emancipação cada vez maior de sua "mensagem particular", em ruptura, portanto, com a tradição, mesmo modernista. Citemos uma passagem que contém o essencial da reflexão do crítico: "A teleologia cabralina não é nacional, é individual - a "formação" do poeta não visa a prossecução do Modernismo estabelecido rumo à homogeneidade da poesia brasileira: visa libertar-se dele - tendo, porém, consequências, e radicais, sobre a teleologia nacionalista: a descrição heróica da vitalidade do Modernismo abriga o princípio da própria ruína, e no ponto programático, aqui expressamente aceito por João Cabral, da configuração duma poesia homogeneamente moderna e brasileira. O heroísmo do poeta inventivo, lutando pela própria libertação, é por si só prova do caráter ilusório dessa homogeneidade e testemunho da inexorabilidade de sua destruição." (p. 54). 
vigentes nas “felizes épocas em que é possível circularem 'poéticas' e 'retóricas'" 354 . Épocas tais como o renascimento, tratada pelo autor no ensaio sobre Miró. Épocas em que vigoram normas que orientam tanto a produção dos poemas, quanto a sua recepção. Com respeito a esta última, e para bem caracterizar o tempo das normatizações, sua função é inequívoca, segundo os termos de Cabral:

A ele [o crítico] cabe verificar se a composição obedeceu a determinadas normas, não porque a poesia tenha de ser forçosamente uma luta com a norma, mas porque a norma foi estabelecida para assegurar a satisfação da necessidade [de comunicação]. O que sai da norma é energia perdida, porque diminui e pode destruir a força de comunicação da obra realizada. 355

A composição contemporânea, por individualista, isenta de toda regra universal, orienta-se por valores contrários: não a comunicação social, mas a expressão original, não o preceito, mas a autenticidade. Aos valores sociabilizados, substituem-se os valores pessoais. Nas palavras de João Cabral:

Ele [o poeta contemporâneo] não está obrigado a obedecer a nenhuma regra, nem mesmo àquelas que em determinado momento ele mesmo criou, nem a sintonizar seu poema a nenhuma sensibilidade diversa da sua. O que se espera dele, hoje, é que não se pareça a ninguém, que contribua com uma expressão original. 356

Se a socialização do poeta, nas "felizes épocas das rétoricas" passava por sua sintonia com um "gosto universal", hoje sua "autenticidade" passa por sua fidelidade sem ser cega ao seu gosto subjetivo, único. Antes, o poeta tinha modelos, reconhecidos por todos, que imitava. Hoje, ele é modelo de si mesmo, e deve ser original. A

354 Obra completa, op. cit., p. 724.

355 Idem, ibidem.

356 Idem, ibidem. 
ausência de toda normatização, inclusive pessoal, caracteriza uma condição histórico-social da criação poética, cujo sintoma principal é o individualismo na conduta criativa do poeta: o poeta "cria as leis de sua composição."

Voltemos à classificação poiética de Cabral. Ainda que comunguem tal sintoma - o individualismo na conduta criativa -, as famílias dos poetas inspirados e dos trabalhadores de arte evidentemente se distinguem entre si. Não iremos comparar a tipologia de João Cabral com as inúmeras distinções feitas, no decorrer da história da literatura, entre inspiração e técnica. A origem, ou, pelo menos, a "formulação exemplar" do conceito de inspiração é remetida a Platão, onde se encontraria uma "teoria del arte fundamentada en la concepción del artista como "médium" de uma divindade 357 . Por seu turno, a origem de uma teoria da conduta técnica em poesia é frequentemente associada a Aristóteles, já que este a considera a partir do ângulo do saber-fazer e do método, prescrevendo-a. É o que afirma Michele Stanco em sua introdução ao livro justamente intitulado "Inspiration and technique: ancient to modern views on beauty and art":

Therefore, while Plato and Neoplatonists mainly consider art from a methaphysical and/or psychological viewpoint and associate it wich supracelestials forms of beauty, Aristotle considers art from a linguistic and communicative viewpoint, and sees it as a text which is supposed to follow a given set of rules if it is to be beautiful. 358

João Cabral, de fato, retoma essa velha distinção. Mas isso depois do Romantismo e do Modernismo, quando o conceito de inspiração sai do plano metafísico para o plano psíquico - “el sueño genesíaco e el

357 STEINER, George. Gramaticas de la creación, op. cit., p. 61.

$358 \mathrm{ROE}$, John e STANCO, Michele (eds). Inspiration and technique: ancient to modern views on beauty and art. Berna: Peter Lang, 2007, p. 20. 
subconsciente" 359 - e o conceito de técnica é pensado na inexistência de toda precepitística socialibilizada. Assim, Cabral tenta estabelecer a diferença entre os dois tipos de $\operatorname{poetas}^{360}$ a partir da distinção entre as “atitudes psicológicas" próprias a cada um dos tipos.

No caso dos poetas inspirados, segundo Cabral, tudo começa com o acontecimento de uma experiência "poética" que o autor transmite diretamente. Como tal experiência é um acontecimento, ela não depende da vontade, como se fosse um "presente dos deuses". A primeira atitude do poeta inspirado é, portanto, a de espera, espera pelo acometimento de um estado subjetivo com valor poético, acometimento que ele não sabe quando virá. Os poetas inspirados, na medida em que esperam a poesia, não a provocam, ou, nas palavras de Cabral, eles “jamais dirigem o motivo de seu poema, jamais se impõem o poema"361. A poesia, nesse caso, vem quando ela quer.

Uma vez a poesia - um certo estado subjetivo - acontecida, o poeta inspirado a manifesta em linguagem tão diretamente quanto possível, segundo afirma ainda João Cabral. Tão diretamente quanto possível: isso significa que a linguagem utilizada para transmitir essa experiência deve estar o mais próximo possível dela. Ou ainda: o poeta inspirado valoriza a expressão primeira desse estado de espírito, quer dizer, ele não a reformula. A reformulação é considerada por ele uma traição da experiência poética, já que o conhecimento desta é intuitivo e não refletido. Reformular o que se escreveu, mudar as palavras e o ritmo com que uma vivência poética imediamente foi expressa é fraudar, para o poeta inspirado, o próprio sentimento.

\footnotetext{
359 STEINER, George, ibidem.

360 Seja dito que, para Cabral, as duas famílias de poetas não se excluem necessariamente. Pode um autor trabalhador de arte aproveitar o que lhe veio sem procura, por obra do acaso (Ver Obra completa, op. cit. p. 725).

${ }^{361}$ Idem, ibidem, p. 731.
} 
O principal valor para o poeta inspirado é, portanto, o estado poético a exprimir, não o objeto poemático a fazer. Não há qualquer motivo ou esquema pré-concebido, neste caso, não há tema objetivo posto. Assim, não interessa ao poeta inspirado a elaboração da linguagem, nem a constituição de um referente, sejam objetos, sejam fatos sociais. Sua linguagem, na medida em que é tradução o mais direta possível de uma experiência que acontece, não é denotativa, antes "evocatica", segundo Cabral, pautada mais no "tom", na musicalidade do que na apresentação analítica ou síntética, “intelectual", de um objeto qualquer ${ }^{362}$.

Não há, dessa forma, trabalho, nem arte na conduta criativa do poeta inspirado, segundo João Cabral, se se entende por trabalho de arte o esforço de construir um poema a partir de uma autodeterminação refletida, quer dizer, intencionalmente.

Tal auto-determinação refletida é o que caracteriza os compositores de poesia pertencentes à outra família. Para estes, conforme João Cabral, o começo da composição é voluntário, deliberado. Nas palavras do autor, "eles [os trabalhadores de arte] se impõem o poema e o fazem geralmente a partir de um tema, escolhido, por sua vez, a partir de um motivo racional"363. Tais poetas, portanto, não valorizam um estado involuntário a exprimir, mas um objeto - o poema - que se busca fazer, ainda que muitas vezes tal objeto poemático exprima uma certa experiência. Mas tal experiência serve de matéria mediata, a ser expressa através de um trabalho lento de elaboração. Essa elaboração é a da própria linguagem de apresentação do tema ou do objeto fixado refletidamente. O trabalho, o esforço de compor é o valor fundamental na conduta criativa de tais poetas.

362 Idem, ibidem, p. 729.

363 Idem, ibidem, p. 733. 
Há no ensaio "Poesia e composição" uma certa valorização da família dos trabalhadores de arte com relação ao poetas inspirados. Prova-o, por exemplo, a avaliação feita pelo poeta, da fatura artística do poemas provindos seja de uma, seja de outra família. No caso dos poetas inspirados, segundo Cabral, a qualidade artística seria insuficiente:

À literatura contemporânea essa atitude [dos poetas inspirados] veio trazer um desprezo considerável pelos aspectos propriamente artísticos da poesia. Ela é completamente incapaz de dar à obra de arte certas qualidades como proporção, objetividade. ${ }^{364}$

Esses mesmo elementos - proporção, objetividade etc - são, por outro lado, encontráveis nos poemas dos poetas trabalhadores de arte, que valorizam, mais que os inspirados, a fatura artística:

[...] não se pode negar que essa atitude [dos trabalhadores de arte] pode contribuir para uma melhor realização artística do poema, pode criar o poema objetivo, [...] e, ao mesmo tempo, pode fornecer do homem que escreve uma imagem perfeitamente digna do ser que dirige sua obra e é senhor de seus gestos. ${ }^{365}$

No entanto, pode-se depreender do texto de Cabral, que essa imagem do poeta que trabalha com arte como "diretor de sua obra" e "senhor de seus gestos", seja ilusória, devido a duas "contradições" que "envenenam" tal conduta criativa. ${ }^{366}$

A primeira contradição tem a ver com a inexistência, de fato, de leis que orientem a execução do poema, e que lança o poeta numa completa ignorância de seu fins. É o que se pode ler na seguinte passagem:

\footnotetext{
364 Idem, ibidem, p. 729.

365 Idem, ibidem, p. 733.

366 Idem, ibidem, p. 734.
} 
[as] leis que ele [o poeta trabalhador de arte] cria para o seu poema não tomam a forma de um catecismo para uso privado, um conjunto de normas precisas que ele se compromete a obedecer. Ao escrever ele não tem nenhum ponto material de referência. Tem apenas sua consciência, a consciência das dicções de outros poetas que ele quer evitar, a consciência aguda do que nele é eco e que é preciso eliminar, a qualquer preço. Com a ajuda que lhe poderia vir da regra preestabelecida ele não pode contar - ele não a tem. Seu trabalho é assim uma violência dolorosa contra si mesmo, em que ele se corta mais do que se acrescenta, em nome ele não sabe muito bem do que. ${ }^{367}$

Na passagem acima, o fazer dos poetas trabalhores de arte se representa através do domínio nocional da negatividade e da redução: o poeta quer eliminar os ecos de outras dicções, ele se corta mais do que se acrescenta. Há aqui, evidentemente, indícios de uma "poética negativa", ou "poesia do menos" bem descritas, respectivamente, por Benedito Nunes e Antonio Carlos Secchin (vide supra $1^{\circ}$ capítulo desta $2^{\mathrm{a}}$ parte). Mas é preciso atentar também para a modalidade epistêmica do enunciado: o poeta, não tendo um ponto material de referência, uma regra preestabelecida, escreve "em nome ele não sabe muito bem do que". Essa ignorância quanto ao fim, põe, consequentemente, o trabalhador de arte sob o signo do "inacabamento pérpetuo" para utilizar uma expressão de Francis Ponge, e que exprime um trabalho feito "à travers la dérive infinie de ses signifiants", de "reprises obstinées et les corrections minutieuses qui ponctuent les versions successives du texte", como intepreta Michel Colliot ${ }^{368}$ o propósito pongiano. É uma ideia semelhante a essa a que encontramos em Cabral, conforme se pode ler nestas palavras:

\footnotetext{
367 Idem, ibidem.

368 COLLIOT, Michel, L'inachèvement perpétuel. Artigo disponível em: http://www.universalis.fr/encyclopedie/francis-ponge/5-1-inachevementperpetuel/.
} 
No tempo em que se reconheciam normas definidas para o verso, a situação era diferente. Estas regras estavam objetivamente fixadas e sua aplicação podia ser objetivamente verificada. A consciência poética era o conhecimento delas, seu domínio e a vigilância ao aplicá-las. O artista tinha onde apoiar-se. Sabia como limitar seu trabalho. Hoje em dia é impossível determinar até onde deve ir a elaboração do poema. Onde interrompê-la. É possível fazê-la prolongar-se indefinidamente. 369

A primeira "contradição", que "envenena" a conduta de arte em poesia é, portanto, a ausência mesma de um parâmetro de determinação do ponto final, ou seja, um critério a partir do qual dar por acabada a obra.

A segunda "contradição" presente no trabalho poético de arte, segundo Cabral, tem a ver com a valorização do fazer em si mesmo. Já vimos, na análise feita acima do ensaio de Cabral sobre Miró, uma forte presença do trabalho pictórico intransitivo, quer dizer, daquele que tem como fim o re-fazer indefinido. Esse mesmo gosto pelo fazer também se encontra na família dos poetas "artísticos", mas de forma excessiva, atingindo a arte literária no "atributo essencial de ser criadora", na medida em que a função do fazer já não seria mais instaurar uma obra "obter resultados concretos" - mas repetir-se incessantemente. Como afirma o poeta:

[...]a preponderância absoluta dada ao ato de fazer termina por erigir a elaboração em fim de si mesma. $O$ trabalho se converte em exercício, isto é, numa atividade que vale por si, independentemente de seus resultados. A obra perde em importância. Passa ser pretexto do trabalho. 370

Tendo não obra, mas o fazer como valor absoluto, o poeta trabalhador de arte acaba por negar o próprio ato de comunicação, que

\footnotetext{
369 Idem, ibidem.

370 Idem, ibidem, p. 735.
} 
deveria ser seu valor principal, pois que seu fazer, enquanto fim de si mesmo, se reduz à intimidade isolada, jamais rompida, de seu ateliê.

Portanto, duas são as "contradições" que "envenenam" a conduta do trabalhador de arte, segundo João Cabral de Melo Neto: a primeira diz respeito à ausência de um critério a partir do qual determinar o fim de uma obra; a segunda diz respeito a um gosto tal pelo fazer que ele o torna fim da atividade compositiva. Entendamos bem a diferença entre as duas contradições. Na primeira, o poeta tem como finalidade uma obra da qual, no entanto, ignora o término. A segunda, a obra não é uma finalidade - e, sim, o próprio fazer - e a questão do término não é sequer posta. A pergunta é: alguma dessas duas contradições está presente na conduta criativa de João Cabral de Melo Neto, poeta trabalhor de arte?

Para responder à pergunta, observe-se, antes de tudo, que os termos da segunda contradição são quase exatamente aqueles que definem a atitude psicológica de Joan Miró, calcada na valorização do trabalho intransitivo. Lembremos que o pintor catalão, para João Cabral, não pinta quadros, ele simplesmente pinta. $\mathrm{O}$ mesmo pode ser dito do poeta que trabalha com arte: este, pela "preponderância absoluta" dada ao ato de fazer, não escreve poemas, ele simplesmente escreve. Mas uma diferença se apresenta. Em Miró, segundo Cabral, o fazer autotélico guarda uma aspiração, a de poder criar "em condições de absoluta liberdade"371. No caso dos poetas, trata-se, ao contrário, de criar dentro de condições extremamente restritas, através da autoimposição de "barreiras formais [...] a fim de ter mais e mais resistências a vencer." 372 . Assim, diferentemente da atitude psicológica de Miró, a atitude psicológica de tais poetas se modaliza axiologicamente de uma forma negativa: aquele ganha em liberdade, estes perdem em

371 Idem, ibidem, p. 717.

372 Idem, ibidem, p. 735. 
comunicação. De fato, segundo Cabral, não tendo mais uma obra como fim - e, sim, o fazer - o poeta acabaria por "matar" a própria função comunicacional, já que ela somente é possível através de obras. Pensando na conduta criativa do próprio Cabral, apesar de sua obra, digamos, pouca, e na medida em que legou poemas que comunicam uma realidade social ou objetual, não se pode concluir que tenha sido contaminado pela segunda contradição. Mas isso na medida em que o gosto pelo fazer não o impediu de escrever poemas comunicativos. Esse gosto, porém, existe em Cabral e está ligado ao esforço de continuadamente retomar o poema, na medida em que não existe um critério para determinar a conclusão da obra, o que nos leva à primeira contradição do fazer há pouco analisada. Ainda que no ensaio "Poesia e composição" tal contradição - ausência do fim onde chegar - também guarde um modalização axiológica negativa, enquanto "veneno" do fazer poético, gostaríamos de mostrar que em outros textos de João Cabral, ela é assumida plenamente. Trata-se de poemas publicados sobretudo a partir do livro Museu de tudo, que analisaremos no subcapítulo a seguir. 


\section{3. "Um poema é o que há de mais instável”}

A ausência de um discernimento, pelo poeta, da forma final da obra se deve às próprias condições históricas das práticas letradas atuais. Em nossa época, segundo Cabral, inexistem normas diretivas do processo compositivo, que, estabelecendo modelos, determinam um critério de acabamento. Isso implica que o material poético pode ser indefinidamente trabalhado, o que acaba por provocar uma atitude psicológica de reformulação incessante, efetuada após cada interrupção do trabalho, tal como se lê neste poema intitulado "As cartas de Dylan Thomas":

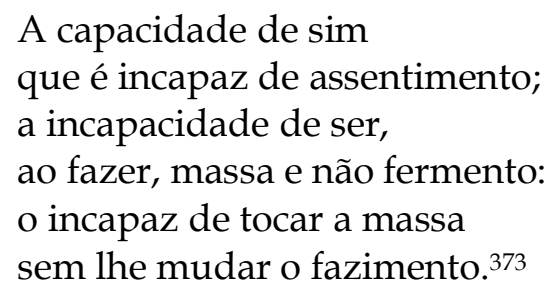

Essa mudança permanente do fazimento é bem uma atitude própria do poeta que desconhece o ponto final de seu poema. Observese que, no texto acima, não há a forte negatividade da primeira contradição do fazer literário - o poeta sabe o que não deve ser seu poema, mas não sabe o que ele deve ser -, aventada por Cabral no ensaio "Poesia e composição". Há, diferentemente, um "sim negativo", como afirma o poeta em outro poema - "O espelho partido" - do mesmo

373 Idem, ibidem, p. 380. 
livro Museu de tudo ${ }^{374}$. Quer dizer, no caso de Dylan Thomas, uma afirmação do fazer que significa uma recusa do já feito.

A inexistência de um critério formal para o fim da obra, implica, por outro lado, a posição da morte como ponto final. É o que se pode ler no poema "Proust e seu livro":

De certo o sabia, quem viveu com a vida e a obra emaranhadas, que viveu fazendo-as, refazendo-as, elastecendo-as em tempo e páginas,

que vestiu sua obra, por dentro, percorrendo-a, viajando em seu barco, decerto viu que um dia acabá-la era matar-se em livro, suicidá-lo. 375

Aqui a identificação entre vida e arte é completa: pôr o ponto final na obra, seria, no caso de Proust interpretado por Cabral, sinônimo de suicídio. Ora, essa identificação implica que o fazer seja representado pela ideia de um inacabamento que é perpétuo enquanto dure a vida do autor. Como afirma Jean-Yves Tadié em um texto justamente intitulado "Proust et l'inachèvement", "seule la mort a empêché [Marcel Proust] de tout refaire, de tout métamorphoser" ${ }^{376}$. Mas esse inacabamento não é, como se vê no caso acima, um processo progressivo rumo à perfeição. O inacabamento implica, antes, uma alteração constante da obra, através de seu refazimento e de sua expansão ("refazendoa/elastecendo-a em tempo e páginas") sem finalidade estética que o limite 377 .

374 Idem, ibidem, p. 403.

375 Idem, ibidem, p. 412.

376 TADIÉ, Jean-Yves, Proust et l'inachèvement. Le manuscrit inachevé/ ed. por Luis HAY Paris : Éditions du CNRS, 1986, p. 84

377 Se se compara o poema de João Cabral de Melo Neto com o estudo genético que Jean-Yves Tadié escreveu sobre Proust, vê-se uma pequena diferença de interpretação. O crítico francês encontra no Cahier XX dos manuscritos do romance Temps retrouvé uma antecipação da palavra "fim", fechando o romance, e que ele intepreta desta 
Ora, são encontrados, na obra de João Cabral, poemas por meio dos quais se representa o fazer não pelo exemplo do outro (Dylan Thomas, Marcel Proust), mas sim do eu, do próprio Cabral, nos quais o limite do inacabamento, da reformulação permanente do poema, não é somente a morte do autor, mas a morte da própria obra, como se pode ler nos versos do poema "O que se diz ao editor a propósito de poemas" do livro A escola das facas (1980):

\author{
Poema algum se autonomiza \\ no primeiro ditar-se, esboçado, \\ nem no construí-lo, nem no passar-se \\ a limpo do datilografá-lo. \\ Um poema é o que há de mais instável: \\ ele se multiplica e divide, \\ se pratica as quatro operações \\ enquanto em nós e de nós existe. \\ Um poema é sempre, como um câncer: \\ que química, cobalto, indivíduo \\ parou os pés desse potro solto? \\ só o mumificá-lo, pô-lo em livro. ${ }^{378}$
}

Teremos a oportunidade de interpretar mais detidamente $\mathrm{o}$ poema acima, do qual transcrevemos as três últimas estrofes, através da análise de seu manuscrito, vendo como as operações de instauração poética, nele enumeradas, funcionam na própria prática criativa que levou à sua composição e à de outros poemas de $A$ escola das facas. Por ora, atentemos para a afirmação explícita da instabilidade inerente ao

maneira: "L'examen, par la critique, de l'inachevé ne mène pas ici à d'autre découverte capitale que l'achèvement, le mot FIN déjà écrit à la fin du Cahier XX du Temps retrouvé, et à chaque étape, Proust a prévu de pouvoir clore (comme le montrent ses lettres à ses éditeurs), comme s'il avait tenté d'oposer le dérisoire achèvement $\mathrm{du}$ mot fin à l'inachèvement essentiel, la mort ». (TADIÉ, Jean-Yves, art. cit., p. 84) Quer dizer, se bem entendemos, com a escrita de um "FIN" no Cahier XX, Proust se anteciparia à morte, mas tal ponto final era somente provisório e não significava de maneira alguma que tivesse chegado à conclusão de seu romance.

378 Obra completa, op. cit., p. 417. 
processo criativo: “Um poema é o que há de mais instável". Tal afirmação se expressa também pela reutilização de uma metáfora vitalista presente em outros poemas do autor, como "Fábula de Anfion" e "Psicologia da composição", qual seja, a metáfora que representa o poema que se faz como um animal, por vezes, indômito. $\mathrm{Na}$ "Fábula de Anfion", a flauta é um "cavalo/solto, que é louco", em "Psicologia da composição", "o poema, com seus cavalos/quer explodir/[o] cimento mudo e fresco" imposto pelo sujeito criador. E no poema acima, o poema é um "potro solto", impossível de ser submetido a não ser com a morte do próprio poema. E a morte do poema - "mumificação" - é a sua publicação em livro, única forma de impedir com que suscite permanentemente o esforço reformulativo do poeta.

Há também no poema acima uma curiosa metáfora do processo criativo: o poema que se faz é como um câncer. Tal metáfora modaliza a noção de existência indefinida do poema ("um poema é sempre"), qualificando-o como doença incurável, quer dizer, como sempre exigindo a intervenção da operação de escrita. A lógica do câncer pode ser apreendida em outro poema, "O espelho partido, cujo objeto é a conduta criativa de um escritor, Marques Rebelo. Neste poema, a metáfora da criação como doença é explícita:
Marques Rebelo compreendeu na criação as leis do câncer: a tensão do que se faz, entre fazer e desfazer, pró e anti. ${ }^{379}$

A imagem da criação como um câncer, formada por conceitos opostos (fazer/desfazer, pró/anti), pode ser compreendida se se pensa a doença como "signo da vida/que multiplica e é destrutiva" 380 , quer dizer, o câncer cresce ("se multiplica") às custas das funções vitais do

379 Idem, ibidem, p. 403.

380 Idem, ibidem. 
doente ("é destrutiva"). Da mesma forma, a criação artística no poema "O espelho partido": o processo de criar ocorre numa tensão nascida do fazer a obra desfazendo-a, quer dizer, modificando-a incessantemente. A lição de Marques Rebelo é uma lição poiética e uma lição de vida): é o "redestilar do câncer/o ácido de um sim negativo", um sim ao fazer futuro (logo, ao viver) que, ao mesmo tempo, nega o já feito (a doença). Tal imagem distingue-se um pouco da do poema-câncer de "O que se deve dizer ao editor a propósito de poemas", já que neste último texto a obra que se faz se multiplica (ou se divide) ao mesmo tempo que esgota o poeta pelo esforço sempre reclamado ("me esgota, vivo em mim, livro-umbigo). Essa natureza ambígua pode ser reencontrada no poema "O postigo", publicado no livro Agrestes, poema que analisaremos a seguir.

Como bem observa Waltencir Alves de Oliveira, trata-se de um "poema de despedida", onde o autor decide fechar seu guichê - o postigo -, no qual negocia a poesia, seu "artigo de venda" 381 , como pode ser lido na primeira estrofe ${ }^{382}$.

Agora aos sesssenta e mais anos,
quarenta e três de estar em livro,
peço licença para fechar,
com o que lestes (?) meu postigo. ${ }^{383}$

O que nos interessa aqui é a explicação para o adeus, que é, ao mesmo tempo, uma explicação do fazer poético. Tal explicação começa na segunda parte do poema que afirma ser o escrever um "ofício dos

381 OLIVEIRA, Waltencir Alves de, O gosto dos extremos. Tensão e dualidade na poesia de João Cabral de Melo Neto, cit. pp. 135 e 136.

382 Preferimos, para a citação deste poema, o texto publicado na edição A educação pela pedra e depois (Rio de Janeiro: Nova Fronteira, 1997), ao texto da Obra Completa. Esta última edição tem, por vezes, erros tipográficos e de fixação do texto. Por exemplo, o quarto verso da primeira estrofe de "O postigo", na Obra completa se edita da segunite forma: "como fizeste meu postigo". Assim publicado, o texto se torna incompreensível.

383 Obra completa, op. cit., p. 584. 
menos tranquilos", retomando-se uma modalização axiológica já presente no livro $O$ engenheiro onde a inquietude é posta como inerente ao fazer. Mas por que o criar é dessa forma modalizado? Leiamos a segunda parte para encontrar a resposta.

\footnotetext{
O que acontece é que escrever é ofício dos menos tranquilos: se pode aprender a escrever, mas não a escrever certo livro.

Escrever jamais é sabido; o que se escreve tem caminhos; escrever é sempre estrear-se e já não serve o antigo ancinho.

Escrever é sempre o inocente escrever do primeiro livro. Quem pode usar da experiência numa recaída de tifo?
}

A inquietude intrínseca ao fazer era expressa, em o Engenheiro, por meio de imagens que dão a ver o processo de criação como incontrolável. Em "O postigo", a intranquilidade se liga a um aspecto cognitivo: a ignorância quanto ao fim onde chegar. Como afirma o poeta, "escrever jamais é sabido", não havendo regras ou fórmulas diretivas que estabilizem o processo de composição ("se pode aprender a escrever, mas não a escrever certo livro"). Vemos aqui a utilização explícita da metáfora do trajeto ("escrever sempre tem caminhos"), que pode ser oposta à metáfora do projeto. Esta implica a clara prévisualização do resultado de cada uma das obras e mesmo da obra completa do autor, que, assim, é vista de forma evolutiva (como o faz João Alexandre Barbosa). Aquela, a metáfora do trajeto, implica, não somente a ignorância do fim, mas rompe mesmo toda linha evolutiva do aprendizado poético, na medida em que "escrever é sempre estrearse". O deslizamento da metáfora do trajeto para a metáfora medicinal 
("escrever como ter tifo") pode reforçar a crítica à visão evolutiva. Com efeito, a cada novo livro, não há fórmula que lhe resolva, de antemão, a composição, tal como o fato de se ter sofrido uma contaminação anterior não garante uma imunidade contra o tifo.

Na terceira parte, a metáfora do escrever como mal do corpo é desenvolvida de certa forma, quando o autor refere a fragilidade de sua velhice ("Aos sessenta, o pulso é pesado"), impotente frente ao "esforço intenso/de escrever".

\author{
Aos sessenta, o pulso é pesado: \\ faz sentir alarmes de dentro. \\ Se o queremos forçar demais \\ ele nos corta o suprimento \\ de ar, de tudo, e até da coragem \\ para enfrentar o esforço intenso \\ de escrever, que entretanto lembra \\ o de dona bordando um lenço. \\ Aos sessenta, o escritor adota, \\ para defender-se, saídas: \\ ou o mudo medo de escrever \\ ou o escrever como se mija.
}

A intensidade do esforço da escrita é uma ameaça à fragilidade do corpo do velho escritor. As saídas ("o mudo medo escrever/ou o escrever como se mija") que adota para não sucumbir, sem que, entretanto não pare de compor, referem a evitação, sempre provisória, do ato de fazê-lo ("mudo medo de escrever") ou ainda a evitação de um enfrentamento prolongado com o poema que se faz ("o escrever como se mija").

$\mathrm{Na}$ quarta e última parte do poema, retoma-se, sob uma outra forma, a metáfora medicinal do escrever, que é coisa "de nervos", e se desenvolve a ideia de que, por isso, o ofício poético torna-se uma 
ameaça à saúde do poeta equanto velho ("Viver de nervos não é higiene/para quem entrado em anos").

Voltaria a abrir o postigo, não a pedido do mercado, se escrever não fosse de nervos, fosse coisa de dicionários.

Viver nervos não é higiene para quem já entrado em anos: quem vive nesse território só pensa em conquistar os quandos:

o tempo para ele é uma vela que decerto algum subversivo acendeu pelas duas pontas, e se acaba em duplo pavio.

Escrever, portanto, é um risco de vida, uma ameaça ao bemestar, devido ao enorme esforço que reclama, e ainda mais se se trata do corpo já fragilizado de um autor "entrado em anos", para quem o tempo é escasso e foge rapidamente como uma vela de "duas pontas". Assim interpretando o final do poema, distanciamo-nos da leitura feita por Waltencir Oliveira da mesma passagem:

O tempo será definido, na última estrofe, e comparado a uma vela acesa de ambos os lados: uma vela só chama [...]. Uma vela pura chama traduz uma obsessão pelo calor e pela luminosidade, ela aquece, ou até queima, e ilumina. [...] uma vela acesa nas duas pontas não caberia em um castiçal, só poderia ser sustentada por mãos hábeis que a mantenha na horizontal com o risco, constante, do quase queimar-se. $\mathrm{O}$ ato de escrever seria, então, um risco e um desafio que o tempo faz aos de "sessenta ou mais anos": o de transitar no "quase", no limiar, sugando do fogo de seu calor e luz, mas driblando, a todo momento, o risco de queimar-se e assim se consumir. ${ }^{384}$

${ }^{384}$ OLIVEIRA, Waltencir Alves de, O gosto dos extremos. Tensão e dualidade na poesia de João Cabral de Melo Neto, cit., p. 137. 
Não podemos concordar com a interpretação da imagem da vela de "duas pontas" - e que define o tempo - como a tradução de uma “obsessão pelo calor e pela luminosidade", porque tal não se lê no texto. Diríamos mais simplesmente que tal imagem - o tempo como uma vela de duplo pavio -, como há pouco afirmamos, quer dizer que, para o velho poeta, o tempo é curto e se consome rapidamente. Por isso mesmo ele "só pensa em conquistar os quandos", em aproveitar ao máximo, e na medida do possível, o tempo que lhe resta, levando-o a uma precaução contra o excesso de trabalho. Por isso mesmo, ainda, o ato de escrever "não é higiene", para esse homem, já que tal ato, sendo "coisa de nervos" se transforma em atribulação, podendo precitar a morte de uma existência já velha e precária.

Podemos, agora, concluir, um pouco longamente, esta parte da tese. No primeiro capítulo (3.1), apresentamos duas imagens que frequentemente a crítica literária utiliza para caracterizar o fazer cabralino: a do poeta-arquiteto e a da mineralização (depuração) da linguagem. Os principais valores subjacentes a essas metáforas são a previsibilidade da obra e a estabilidade do material (linguístico). Quer dizer, trata-se de obter um controle total do processo criativo por meio de uma concepção (projeção) lúcida da obra, passando por uma realização rigorosa que leva a um resultado conforme ao projetado. A rigorosa realização implicaria uma instrumentalização da palavra, através de sua "transformação em pedra", ou seja, do polimento de toda aresta semântica excessiva ("poesia do menos").

No segundo e no terceiro capítulos (3. 2 e 3. 3) tentamos propor elementos que relativizam tais imagens. Primeiro, mostrando como em O engenheiro a criação é representada, com o uso de metáforas vitalistas, 
a) por meio de espaço-tempo, a página, (lugar onde o processo de escrita acontece), sinônimo de fertilidade (onde verso desabrocha) e de esterilidade (onde o verso seca); b) por meio de um domínio nocional onde se alocam as ideias de expansão e de devir, por vezes incontroláveis; c) através de modalidades que representam o fazer principalmente como algo inquietante, portanto instável.

Segundo, mostrando como a concepção de um procedimento arquitetônico perfeitamente controlado pela pré-visão projetual é posta em xeque na fábula que narra a construção de Tebas por Anfion. A lição que, acreditamos, se deve tirar dessa fábula, cujo fim representa a assimetria entre o que foi concebido e o que foi realizado, é que a ideia de uma poiética do canteiro é mais desejável que a de uma poiética do projeto, se se quer evitar o triste fracasso do arquiteto Anfion.

Terceiro, ao mostrar que, na "Psicologia da composição", o controle do processo de criação está sempre sob a ameaça da - é é por vezes subjugado pela - variabilidade e fragilidade intrínseca ao próprio sujeito criador e à obra que se faz. Nesse sentido, a imagem do fazer literário como uma tauromaquia configura uma melhor representação do da conduta cabralina, já que esta última inclui necessariamente o perigo (o acaso), e o inclui tanto mais na medida em que se tenta aplicar com todo rigor possível a regra (o controle).

Quarto, evidenciando, por meio da análise de textos teóricos e poemas diversos de Cabral, que escrever significa sobretudo reescrever, ou seja, que a reescrita ou reformulação é essencial ao fazer poético, e que a intenção (o projeto) pode ser transformada imprevisivelmente no decorrer do processo reformulativo. Não há propriamente um fim onde chegar estabelecido de antemão, e o poema só termina quando é "mumificado" em livro. Nesse caso, uma poiética do trajeto se sobreporia à poiética do projeto, fazendo jus ao que o próprio Cabral afirma: 
Escrever jamais é sabido;

o que se escreve tem caminhos. ${ }^{385}$

Esta parte da tese tentou mostrar, então, que a metáfora do poeta-arquiteto e da mineralização da linguagem, quer dizer, que a ideia de um domínio total do processo criativo, em Cabral, é falsa? Como já pudemos indicar no primeiro capítulo desta segunda parte, talvez a maneira arquitetônica de ser o poeta esteja determinada por uma recepção crítica específica, que poderíamos identificar, sobretudo, com a do concretismo. Já Ferreira Gullar havia pensado algo nesse sentido. Instado a dizer o que pensa sobre o fato de os concretistas considerarem João Cabral um precursor, o poeta responde:

Eles [os concretistas] achavam que João Cabral era um exemplo de que a poesia tinha que caminhar para o concretismo, o que era uma bobagem, porque a arte não evolui. [...] João Cabral não tinha nada a ver com o concretismo. [No entanto] João Cabral se inventou o contrário do que ele era, ele se inventou um poeta racional, objetivo, equilibrado e formal ${ }^{386}$

Essa mesma questão foi posta de forma mais aguda por Thaís Mitiko Taussig Toshimitsu. A autora afirma, explicitamente, que “o lugar reservado a João Cabral ficou marcado por um argumento que interessava à defesa de uma vanguarda na visão e no desejo dos concretistas" ${ }^{387}$. Tal visão destacaria o lado puramente formalista da poesia - "arquitetônica" - de Cabral, segundo ainda os termos da pesquisadora:

\footnotetext{
385 Obra completa, op. cit., p. 584.

386 in VASCONCELOS, Selma, João Cabral de Melo Neto: retrato falado do poeta, op. cit., p. 138.

387 TOSHIMITSU, Thaís Mitiko Taussig, O rio, a cidade e o poeta, cit., p. 22.
} 
A ideia da "preponderância da vontade da forma", para a poesia cabralina, tornou-se praticamente hegemônica, o que resultou em anos de trabalhos acadêmicos e ensaios críticos debruçados sobre a tentativa de desvendar os engenhos construtivos de sua poesia, [...] de tornar clarividente a lucidez e racionalidade do método de composição de Cabral. ${ }^{388}$

E é preciso afirmar que o próprio Cabral alimentou sua imagem de poeta dotado de um controle arquitetônico sobre o processo compositivo, como se pode verificar através das numerosas declarações do autor em que assume a arquitetura como símile do fazer poético. Por exemplo, quando afirma em uma entrevista:

Para mim, a poesia é uma construção, como uma casa. Isso eu aprendi com Le Corbusier. A poesia é uma composição. Quando digo composição, quero dizer uma coisa construída, planejada. ${ }^{389}$.

Ora, sabe-se o quanto Le Corbusier propugnava uma arquitetura da prevalência do projeto sobre o canteiro: "le plan est le générateur"; "Le plan est à la base"; "Le plan est la détermination du tout; il est le moment décisif", afirma o arquiteto ${ }^{390}$. Ou ainda :

A arquitetura é uma ordenação; é no cérebro que a operação se efetua; a folha de papel não acolherá senão os sinais técnicos úteis para manifestar e transmitir esse pensamento. ${ }^{391}$.

Ou seja, a concepção se sobrepõe ao processo realizativo, dominando-o como uma idéia determinante e reguladora. Essa última afirmação de Le Corbusier, porém, contrasta completamente com

388 Idem, ibidem, p. 17.

389 Entrevista publicada nos Cadernos de Literatura Brasileira, no 1, São Paulo: Instituto Moreira Sales, março de 1996

390 "Trois rappels à MM. Les architectes", L'esprit nouveau, $\mathrm{n}^{\mathrm{0}} 4$, apud LUCAN, Jacques. Composition, non-composition. Architecture et théories, XIXe - XXe siècles. Lausanne: Presses polytechniques et universitaires romandes, 2010, p. 367.

391 Quand les cathédrales étaient blanches. Paris: Gonthier, s/d, apud FERRO, Sérgio, Arquitetura e trabalho livre, op. cit., p. 136. 
diversas passagens de Cabral, como, por exemplo, os seguintes versos de "Lição de poesia" ( $O$ engenheiro), que já comentamos:

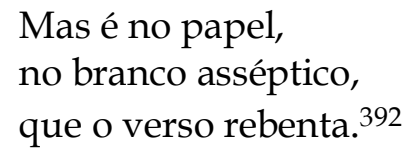

A valorização da página inverte a lógica compositiva de Le Corbusier, já que para este é no "cérebro" e não no papel que ocorre o essencial da criação. Mas apesar de encontrarmos na obra de João Cabral de Melo Neto inúmeras passagens que relativizam o procedimento arquitetônico, o poeta se afirma e reafirma um arquiteto. Ora, considerada a influência concretista e sua poderosa política literária, não seria o caso de considerar essa auto-representação de João Cabral, combinada com a condenação que faz dos poetas que cultivam um lirismo subjetivo, e que não seriam construtivistas, como um lance no jogo do "campo literário", em busca de uma consagração mais duradoura? É uma hipótese que propomos tendo em mente a teoria do "campo literário", levada a cabo por Pierre Bourdieu. O sociólogo francês afirma o seguinte:

aqueles que estão certos do reconhecimento de seus pares, suposto indício de uma consagração duradoura (a vanguarda consagrada), opõem-se aos que não chegaram ao mesmo grau de reconhecimento do ponto de vista dos critérios específicos. ${ }^{393}$

Resta, porém, dirá algum contestador, que Cabral, de fato, projetou macro-estruturas, por exemplo, a quaternidade de Serial e a dualidade de $A$ educação pela pedra, além de uma métrica rígida e um número específico de estrofes, o que demonstraria que o poeta procedia

392 Obra completa, op. cit., p. 76.

393 BOURDIEU, Pierre, As regras da arte. São Paulo: Companhia das letras, 1996, p. 248. 
"matematicamente", que "calculava" previamente seus poemas. Ao que responderemos que tais estruturas vazias e externas nada têm a ver com as estruturas propriamente poéticas, que são sintáticas e semânticas. Ferreira Gullar, relatando um conversa que teve com João Cabral sobre sua (de Gullar) relação com os concretistas, afirma algo em nosso favor; a citação é longa, mas importante:

Em junho [de 1956], [os concretistas] escreveram um artigo, levando ao extremo a desintegração da expressão verbal como linguagem, que denominaram: "Da fenomenologia da composição à matemática da composição". Então eu liguei pro Augusto, e disse: "Augusto, isso é uma coisa inviável, você me desculpe, mas eu digo a você que não há relação causal entre matemática e linguagem verbal. Logo, não pode cálculo matemático determinar a palavra do poema". A esta altura, João Cabral retrucou: "Mas poesia pode ser feita matematicamente; meu livro A educação pela pedra é todo múltiplo de dois!" [Ao que Gullar contrapôs] "Não é que não se possa usar as palavras dentro de estruturas matemáticas, isto pode, mas são relações externas, como no soneto, no decassílabo, na redondilha. A matemática é externa à linguagem, ela pode determinar a medida do verso, o tamanho da estrofe, a composição. Mas não determina internamente a estrutura do verso como eles [os concretistas] queriam". João Cabral parece concordar $[\ldots]$ e desata em risos. ${ }^{394}$

Se a matemática é "externa" à poesia, se a poesia não é um "desenho" geometricamente calculado, então ela não é arquitetura. $\mathrm{Ou}$, pelo menos, não uma arquitetura que sobrepõe o projeto ao canteiro determinando-o completamente.

O poeta "trabalhador de arte", se não é "inspirado", para usar a tipologia cabralina, tampouco é, apenas, um projetista obstinado (Anfion), mas alguém que se esforça por instaurar uma obra, sempre se surpreendendo com a instabilidade da linguagem, desconhecendo a forma final do poema. Localizando-se entre esses dois mitos, o do poeta dominador absoluto e o do poeta da pura espontaneidade, João Cabral

394 In VASCONCELOS, Selma, João Cabral de Melo Neto: retrato falado do poeta, op. cit., p $134-135$. 
talvez pudesse ser classificado como um escritor "de bordejar", pensando-se em outra tipologia, agora proposta por Osman Lins. Em Guerra sem testemunhas, o romancista distingue três tipos de escritos: os sacrais ou inspirados (os que são "conduzidos por um mentor invisível"), os "escritos cursivos" (aqueles que "seguem um curso conhecido [...] para o próprio escritor" e que poderiam ser indentificados com os produzidos por um suposto poeta-engenheiro) e, finalmente, os escritos "de bordejar" ("aqueles dos quais bem pouco sabe o escritor ao empreendê-los e ao longo dos quais, arduamente, avança e descobre" $)^{395}$. Ora, ainda que João Cabral tenha prefigurado certas estruturas (como dissemos, externas), muito havia ainda a ser feito e descoberto no papel durante o processo compositivo. Portanto, diferentemente do que pensava Le Corbusier, para quem a mão do pintor, depois de uma "longa preparação", nada mais busca na tela, mas apenas executa ${ }^{396}$, João Cabral, diferentemente, no trabalho sobre a página, descobre e formula estruturas que não havia ainda projetado. É o que gostaríamos de mostrar mais detalhadamente na parte seguinte desta tese, onde se trata de analisar os manuscritos do autor, cujos traços representam seu trajeto compositivo.

395 LINS, Osman, Guerra sem testemunhas. O escritor, sua condição e a realidade social, São Paulo: Editora Ática, 1974, pp. 18-19. Durante nosso estágio no Instituto de Estudos Brasileiros (IEB - USP), sob a orientação de Sandra Margarida Nitrini, entre os anos 2007 - 2008, pudemos ter acesso a alguns manuscritos de Osman Lins que esclarecem sua conduta criativa. Referimo-nos aos prototexto de seu último romance (inacabado), A cabeça levada em triunfo, onde, no plano escrito pelo autor pode ser lido o seguinte: “Este romance [...] é sobre Cabeça e Corpo. Dentro disso mergulha a história da cabeça e mergulha a história da moça. Mais, a própria concepção do romance deve, em parte, ser racional, e, em parte, instintiva." (Caixa A cabeça levada em triunfo. Fundo pessoal de Osman Lins, Arquivo do Instituto de Estudos Brasileiros (IEB - Universidade de São Paulo).

396 "Para fazer um quadro é necessário pegar uma tela ou uma prancheta, traçar o desenho, pegar a tinta e espalhá-la com os pincéis. A recompensa para quem se dedicou a uma longa preparação é que ele não busca mais na tela: ele executa" apud FERRO, Sérgio, Arquitetura e trabalho livre, op. cit., p. 250. 


\section{PARTE 3. PRÁTICA DA CRIAÇÃO: OS MANUSCRITOS DE JOÃO CABRAL DE MELO NETO}


Pode-se dizer que fizemos, na parte anterior, uma leitura poieticamente orientada de poemas metalinguísticos de João Cabral, interessando-nos sobretudo por aquilo que é imprevisível na relação entre sujeito criador e obra a fazer. As metáforas vitalistas da criação do livro $O$ Engenheiro, o fracasso de Anfion, cujo desenho arquitetônico não se realiza, a atividade constante de re-fazer etc., são alguns exemplos de quanto as imagens do poeta-arquiteto e da "mineralização" da palavra, que representam o fazer como um processo pré-visto e controlado, devem ser relativizadas. Em Cabral, a imprevisibilidade da obra por vir se representa ou por meio de metáforas vitalistas, mas poderia também, sem forçar a interpretação, ser representada pela imagem da tauromaquia, onde regra e perigo são essenciais à conduta artística, ou também, se se considera a metáfora arquitetônica, pela sobreposição do canteiro ao projeto, de tal maneira que este se transforma, imprevisivelmente, durante os trabalhos de realização. Se se pensa em termos puramente literários, essa imprevisibilidade é fruto da indefinida reformulação do poema devido à instabilidade intrínseca ao material linguístico.

Este último aspecto, o fazer literário como reformulação (paráfrase) contínua de um texto anterior, será justamente o objeto desta terceira parte, que considerará a reformulação não como um conceito que representa o fazer, mas como a atividade mesma de escrita, e isto por meio da análise dos traços manuscritos da conduta de Cabral. 
No $2^{\circ}$ capítulo da $1^{\circ}$ parte desta tese esclarecemos o que compreendemos por reformulação textual (ou paráfrase): trata-se da produção de um texto que é equivalente e/ou assimétrico a um texto de origem. Assim entendida, a atividade de reformulação é fundamental para a problemática posta nesta tese. Por um lado, como produção mais de equivalências que de assimetrias, ela fornece os meios por onde descrever, quando acontecem, a realização de uma intenção de significação (o procedimento arquitetônico), bem como os que os críticos chamam de "mineralização da linguagem", já que esta é compreendida como depuração das significações "indesejadas", logo, como uma produção de séries de equivalências que conservam somente o essencial da nomeação, produzindo assim, progressivamente, enunciados mais "precisos". Por outro lado, a atividade de reformulação como produção de assimetrias semânticas, mais que de equivalências, dá a descrever o que há de processual - não programático -, e, logo, de imprevisível, na conduta criativa cabralina. Pois a reformulação assimétrica, como produção de textos semântica e estruturalmente diferentes com relação ao texto de origem, mostra que uma intenção de princípio pode se transformar completamente no decorrer da escrita, e, mesmo, que essa intenção somente é constituída no decorrer da atividade reformulativa.

A natureza dos manuscritos de Cabral, aliás, justifica que os leiamos por essa chave, já que, como veremos detalhadamente, o autor trabalha a partir da releitura de poemas em estado avançado de composição, introduzindo, no entanto, modificações que muitas vezes vão além de correções pontuais, transformando profundamente o sentido e a estrutura dos textos. 
Assim em um primeiro momento, faremos uma apresentação não exaustiva do espólio literário do poeta depositado na Fundação Casa de Rui Barbosa, na cidade do Rio de Janeiro. A seguir, analisaremos alguns mansucritos retirados de três dossiês genéticos. $\mathrm{O}$ primeiro relativo ao livro Serial, do qual, além da mudança de título, analisaremos as reformulações da primeira série do poema "Velório de um comendador", em seguida, da primeira série de "Escritos com o corpo" e, finalmente, as reformulações do poema "Graciliano Ramos:". O segundo dossiê diz respeito ao livro A educação pela pedra, do qual analisaremos as modificações operadas sobre diversos poemas, que serão convenientemente indicados. Teremos a ocasião, neste caso, de estudar as diferenças entre a primeira composição do livro e sua forma publicada. Por fim, o terceiro dossiê genético é relativo ao livro A escola das facas, do qual selecionamos três manuscritos, os do poema "O que se diz ao editor a propósito de poemas", os do poema "Prosas da maré na Jaqueira" e, finalmente, os do poema "Descoberta da literatura". Neste caso, teremos mais uma vez a oportunidade de analisar as operações de que João Cabral lança mão ao transformar seus textos durante o proceso de escrita. O critério para a escolha dos documentos analisados foi simplesmente sua riqueza genética, quer dizer, escolheram-se os manuscritos de textos mais intensamente reescritos.

O arquivo literário de João Cabral de Melo Neto, depositado na Fundação Casa de Rui Barbosa, na cidade do Rio de Janeiro, apesar de sua riqueza, está incompleto, já que não há documentação referente aos poemas publicados antes de Serial (1961); está, ainda, relativamente desorganizado, já que falta uma cronologia possível e uma disposição adequada dos documentos; e, finalmente, quase inteiramente 
inexplorado, pois não nos consta nenhum trabalho realizado a partir dos manuscritos localizáveis no Rio de Janeiro

O arquivo é constituído de três caixas de documentos, duas contendo o que seus organizadores da Fundação Casa de Rui Barbosa denominam de "produção intelectual" (Pi) e uma que contém a correspondência recebida pelo autor.

Entre a correspondência encontram-se cartas endereçadas a João Cabral por Murilo Mendes, Lauro Escorel, José Guilherme Merquior e Guimarães Rosa, para nos restringirmos somente às mais volumosas.

A chamada "produção intelectual" (Pi.), por sua vez, é um ajuntamento de documentos de natureza diversa. Não somente encontramos aí manuscritos de poemas, mas também manuscritos de textos críticos e entrevistas corrigidas, além da documentação ligada à atividade diplomática de João Cabral, como, por exemplo, uma cópia da ação movida por João Cabral contra sua expulsão do Itamaraty, em 1953, baseada em uma acusação de comunismo ${ }^{397}$.

Com respeito aos manuscritos de textos especificamente literários, encontramos no fundo pessoal do autor uma documentação ligada, sobretudo, a poemas publicados nas seguintes obras: Serial (1961), A educação pela pedra (1966) e A escola das facas (1980) que constituem o material mais interessante do ponto de vista genético e que são justamente o objeto de nossas análises. Podem ser encontrados em anexo algumas cópias fotográficas e transcrições de quase todos os documentos aqui referidos.

397 Sobre o episódio, pode-se consultar o seguinte livro: LUCAS, Fábio, O poeta e a mídia: Carlos Drummond de Andrade e João Cabral de Melo Neto. São Paulo: Senac, 2002. 


\section{Capítulo 1. O dossiê genético de Serial}

\section{1. Descrição do dossiê}

É o dossiê mais antigo (o livro é publicado em 1961, no volume Terceira Feira) dos que se podem encontrar no arcevo de João Cabral de Melo Neto. Segundo a catalogação da Fundação Casa de Rui Barbosa, os documentos referentes ao dossiê de Serial podem ser localizados em duas pastas distintas: Pi. Serial e Pi. Poesia partida em quatro. Essa organização é um equívoco, pois as duas pastas contêm um material homogêneo, inteiramente ligado ao livro Serial, cujo primeiro título era Poesia partida em quatro. Com efeito, na pasta Pi. Poesia partida em quatro encontramos os datiloscritos corrigidos dos poemas a seguir, em fólios soltos numerados de 1 a 28, mais um fólio não numerado.

"A cana dos outros" (fólios 1-4)

"Formas do nu" (fólios 5-8)

"A chuva em Carpina" (fólios 9-10)

"A chuva em Sevilha" (fólios 11-12)

"A chuva na Galícia" (fólios 13-14)

"A chuva no Sertão" (fólios 15-16)

"Clares Varones" <"Generaciones y semblanzas"> (fólios 17-24)

“Pernambucano em Málaga” (fólios 25-28)

"O motorista imaginese" <"O automobilista infundioso" > (em um fólio não numerado que contém a primeira parte do poema). 
Quer dizer, trata-se dos manuscritos de 6 poemas de Serial, “A cana dos outros", "Formas do nu", "Chuvas" (que, no arquivo, tem suas quatro partes intituladas separadamente), "Generaciones y semblanzas" (cujo primeiro título era "Claros Varones"), "Pernambucano em Málaga" e o início do "O automobilista infundioso" (cujo primeiro título era "O motorista imaginoso").

Agora, na pasta Pi. Serial, encontramos 42 fólios soltos, numerados de 30 a 72, mais 17 fólios não numerados, referentes aos seguintes poemas:

"O motorista imaginoso" <"O automobilista infundioso"> (fólios 3032 , onde constam as três últimas partes do poema).

“O relógio (-pássaro)” (fólios 33-34).

“O relógio (- operário)" (fólios, 35-36).

“O relógio (-monjolo)” (fólios 37-38).

“O relógio (-bomba motor)" (fólios 39-40).

“Velório de um comendador" (fólios 41 -48)

“Graciliano Ramos:” (fólios 49 -52).

“O ovo de galinha" (fólios 53-56)

“Escrito com o corpo" (fólios 57-63)

“O alpendre no canavial” ( fólios 65-72).

Os fólios não numerados referem-se aos poemas:

“Uma sevilhana na Espanha",

"Pescadores pernambucanos", 
"Adultos do engenho" <"Claros varones"> e

"O sim contra o sim".

Observe-se que, no dossiê, o poema "O relógio" tem cada uma de suas quatro partes intitulada separadamente; que o poema "Claros varones" se intitulava "Adultos do engenho"; e que o poema "Escritos com o corpo" tinha como título primeiro "Escrito com o corpo". Perfazse, assim, a totalidade dos poemas de Serial. Mas, como se pode verificar no dossiê, o título Serial não existe ainda, mas somente Poesia partida em quatro, o que nos leva a concluir que todos os documentos das duas pastas deveriam ser agrupados em uma só, com o título Pi. Poesia partida em quatro (primeira versão de Serial.

Nossa análise se restringirá aos manuscritos referentes a três textos, escolhidos por causa de sua riqueza genética: a primeira parte de "Velório de um comendador", a primeira parte de "Escrito com o corpo" (que foi publicado com o título "Escritos com o corpo"), e todo o poema "Graciliano Ramos:". Além desses prototextos, examinaremos a importante mudança de título do livro, de Poesia partida em quatro para Serial.

Antes, porém, algumas palavras sobre o tipo de documento genético aqui analisado: quase todos são datiloscritos reformulados a mão pelo autor. Isso significa que os textos estavam, antes das reformulações, em um estado avançado de composição. Pode-se mesmo dizer que os textos já estavam inteiramente compostos, pois não lhes falta parte alguma. Porém, que estivessem inteiramente compostos não significa que estivessem acabados, como mostram as reescritas que, por vezes, os transformam radicalmente. Isso diz algo sobre o "ritmo 
genético", para usar uma expressão de Jean-Louis Lebrave ${ }^{398}$, de João Cabral de Melo Neto. Pode-se dizer que o poeta trabalhava em "périodes de travail distinctes, en unités temporelles de production"399. Quer dizer, Cabral depois de escrever seus poemas, datilografava-os e, inaugurando mais um perídodo de trabalho, reformulava-os a partir desses datiloscritos e assim sucessivamente.

Procederemos, na $1^{\mathrm{a}}$ parte deste capítulo, analisando, de início, a mudança do título Poesia partida em quatro $\rightarrow$ Serial, já que ele determina a relação mesma entre as diversas partes dos poemas que compõem o livro. Em um segundo momento, vamos analisar certas reformulações da primeira parte do poema "Velório de um comendador", com a intenção de mostrar como João Cabral, por meio de paráfrases, alcança uma representação mais adequada de seu objeto. Em um terceiro momento, trataremos de certas reformulações da primeira parte do poema "Escritos com o corpo", a fim de observar como Cabral pode proceder diferentemente do exemplo anterior, produzindo uma série de reformulações que modificam completamente a representação que fizera de seu objeto. Por fim, analisaremos os manuscritos do poema "Graciliano Ramos:" para mostrar como o processo reformulativo acaba por engendrar não somente diferenças semânticas mas propriamente estruturais.

\footnotetext{
398 LEBRAVE, Jean-Louis, L'écriture interrompue: quelques problèmes théoriques. Le manuscrit inachevé. Écriture, création, communication. op. cit.

${ }^{399}$ Idem, ibidem, p. 145.
} 


\title{
1. 2. Divisão e seriação: a mudança de título
}

Comecemos pela análise da mudança de título. Na fronte do proto-Serial lê-se que o livro era intitulado de outra forma:

\author{
$<$ POESIA $>$ \\ POEMAS \\ $<\mathrm{A}>$ \\ PARTIDOS \\ EM QUATRO
}

Há, portanto, no manuscrito a seguinte operação de substituição:

poemas partidos $\rightarrow$ poesia partida

Uma vez que o livro foi publicado com o título Serial, e podendo tal título ser lido elipticamente ([poesia] serial), podemos deduzir que houve uma outra substituição operada pela autor, ainda que dela não haja traço manuscrito:

\section{[poesia] partida em quatro $\rightarrow$ [poesia] serial}

A primeira reformulação, onde o sujeito do título original (poemas partidos em quatro) é substituído (poesia partida em quatro), não põe grandes problemas de interpretação, já que a relação entre ambos é de quase identidade. A única diferença semântica (passagem do múltiplo (poemas) ao um (poesia), pode, sem perdas maiores, ser neglicenciado. O mesmo não ocorre com a substituição poesia partida em quatro $\rightarrow$ [poesia] serial. A predicação (partida, no texto-fonte, serial, no texto publicado) explicita a operação que está na base da relação das partes dos poemas entre si. Nota-se, assim, que todo o livro foi concebido e realizado a partir da ideia de divisão e que o título Serial 
foi escolhido como que a posteriori - já que não houve nenhuma alteração na relação entre as partes dos poemas com a nova intitulação. A pergunta a ser posta é: por que João Cabral reformulou o título, fazendo com que fosse possível pensar os poemas não como "partidos", mas como seriados? O esclarecimento dos conceitos de divisão e seriação, bem como a análise da relação entre as partes de alguns poemas talvez nos possam dar uma resposta.

A divisão pode ser definida como "la décomposion d'un tout en ses éléments" ${ }^{400}$. Portanto, trata-se de uma análise do homogêneo, já que se pressupõe uma unidade que se divide em partes. Considerando-se os poemas de Poesia partida em quatro, as diversas partes nas quais são divididos têm, entre si, uma relação de quantidade e de qualidade. Quantitativamente são iguais, na medida em que a divisão, no livro, é sempre por quatro ${ }^{401}$. Qualitativamente, porém, a relação não é sempre a mesma, o que acabará por mostrar o limite da divisão como critério da relação entre as partes dos poemas. Com efeito, uma vez a divisão efetuada, enquanto análise do homogêneo, deverá ser possível uma síntese que, de novo, reunifique as partes em um todo. Por exemplo, o poema "A cana dos outros" 402 pode ser pensado como uma divisão, em quatro fases, do cultivo da cana no engenho. A primeira é a planta, a segunda, a limpa, a terceira o corte e a quarta, a moedura. Perfaz-se, por

400 SOURIAU, Etienne, Vocabulaire d'esthétique. Paris : PUF, 1990, p. 603.

401 A importância desse número no arcabouço formal do livro já foi devidamente enfatizada por Antonio Carlos Secchin. Mostra o crítico como o esquema quartenário está presente em vários aspectos formais dos textos: rímico ("aabb em quatro poemas e -a -a nos restantes"), métrico ("quatro textos em hexassílabos, quatro em heptassílabos, quatro em octassílabos e quatro combinações diversas entre hexassílabos e octossílabos), estrófico ("quatro poemas com segmentos de duas estrofes, quatro de quatro, quatro de seis, quatro de oito), marcação tipográfica ("O grifo incide em quatro categorias (substantivos comuns, substantivos próprios, adjetivos e verbos e em quatro poemas atinge os substantivos próprios) e, finalmente, na separação das partes ("para a separação de seus quatro segmentos, quatro poemas se valem de números, quatro de asteriscos, quatro de parágrafos, e quatro de travessões). (SECCHIN, Antonio Carlos, João Cabral: a poesia do menos, op. cit., p. 188).

402 Obra completa, op. cit., pp. 291 - 292. 
essa divisão, o ciclo vital completo da cana-de-açúcar. Vital, porque se parte de seu nascimento, quando é plantada, até seu enterro, conforme se lê, na "tumba-moenda". O poema divide o processo de tratamento da cana no engenho, dando-nos, ao mesmo tempo, uma visão de conjunto desse mesmo processo.

A operação de divisão, porém, não é tão explícita em outros poemas. Por exemplo, "O sim contra o sim" e "Claros varones", poemas que, como notou Antonio Carlos Secchin, são compostos de “segmentos que, embora unidos aos demais por um parentesco semântico, se permitem leitura autônoma"403. Essa autonomia dos segmentos torna difícil considerar os poemas como um todo que se divide, logo como "poemas partidos". De fato, em tais poemas não há, no início, um todo homogêneo que se analisa, mas antes uma heterogeneidade que se busca sintetizar, se se pensa que a seriação, como mostra Gilles Deleuze, é um operação de "síntese do heterogêneo"404. E Benedito Nunes, fazendo referência ao filósofo francês, analisou como tal operação funciona no poema "Velório de um comendador". Citemos o crítico:

Em o "Velório de um Comendador", os objetos banais intensificam o insólito das poses macabras, que são estados morais coisificados, de um defunto ilustre. O estranhamento vem do contraste entre duas séries verbais diferentes que focalizam o mesmo objeto. Ora se afastando, ora se aproximando, sem de todo coincidirem, essa séries, cada qual através de uma cadeia autônoma de termos, visam [...] um referente comum [o comendador morto]. ${ }^{405}$

Ou seja, enquanto séries, cada um dos segmentos do poema se torna uma "cadeia autônoma" que desenvolve um aspecto específico do referente de base. Embora girem em torno do mesmo referente, uma

403 SECCHIN, Antonio Carlos, A poesia do menos, op. cit., p. 189.

${ }^{404}$ DELEUZE, Gilles, Logique du sens. Paris: Seuil, 1967, p. 50.

405 NUNES, Benedito, João Cabral de Melo Neto, op. cit., p. 125. 
série é independente da outra para ter seu sentido apreendido. Essa autonomia, no entanto, é impensável se se considera o princípio de divisão, presente no primeiro título do livro, já que como parte de um todo, cada segmento seria fragmentário em si mesmo, e seu sentido só seria alcançado perfeitamente quando posto em relação com as outras partes.

Essa diferença essencial entre divisão e seriação talvez explique a subsituição do título Poesia partida em quatro pelo título Serial. Embora os poemas do livro tenham sido concebidos a partir da ideia de divisão, a verdade é que muitos deles, depois de realizados, acabaram por apresentar segmentos perfeitamente autônomos, o que tornava problemático considerá-los como partes de um todo. Talvez esse aspecto autonôno dos segmentos tenha levado Cabral à mudança de título. Mas a modificação não esconde o fato de alguns segmentos ainda funcionarem como partes, tal como foram pensados originalmente, ou seja, como um texto cujo sentido se completa somente quando posto em relação com as outras partes do poema, tal como se pode verificar através do poema, já citado, "A cana dos outros". 


\section{3. Construção da crítica social: reformulações do poema "Velório de um comendador"}

As reformulações efetuadas por Cabral podem ter a equivalência como valor dominante, introduzindo modificações que servem para produzir uma representação mais adequada do objeto. É o que podemos observar no manuscrito da primeira parte do poema "Velório de um comendador", que transcrevemos a seguir. Um cópia fotográfica do manuscrito pode ser encontrada no anexo 1 desta tese. 


\section{VELÓRIO DE UM COMENDADOR}

Os que o conheceram vivo

e agora o visitam, morto,

pensarão: do antigo rio

são restos de banho morno

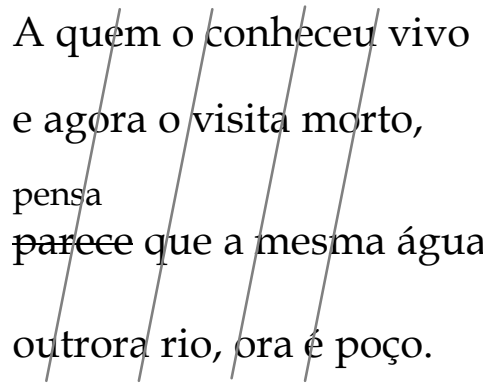

Os que o conheceram vivo

e agora o visitam morto,

estarão pensando: o rio

outrora enchente, ora é poço

murcha

Agora está estagnada

poço

no ataúde tina, ou jarra,

invasora

a água sedenta que ele era,

água com sede de água.

Nenhuma

Nem uma brisa de fora,

infiltrando-se ligeira

coando por qualquer fresta,

arrepia a superfície

da inundação que ele era .

Entorpecida, água poşa,

na

numa banheira de salão

enchente sempre que foi

a água invasora que ele era

morre na estagnação.

vive

está incapaz de invasão.

A brisa de fora entra

e arrepia as baronesas

que brinca nas flores

A brisa então arrepia

como baronesas da água as baronesas dessa água

mas nem de leve arrepia

sua superfície estagnada

Quiçá porque

Talvez é que a água morta

se torne mais densa, grossa,

insensível aos dedos leves

fazendo

da brisa, de sua cócega

que hoje a aflora 
Não há

Sem dúvida, a água morta

se torna muito mais densa:

ao menos sevê

parece que está boiando

ao menos, se vê boiando

uma

o metal de sua comenda.

compreende

Só $<N>/$ n/ão se entende-é porque

respeita

a água não rompe o caixão:

mais densa, pesará mais

a

e tem mais forte sua pressão.

E pensar que enquanto viva

não respeitava reprêsa

e que hoje morta a detém

dique de simples madeira.

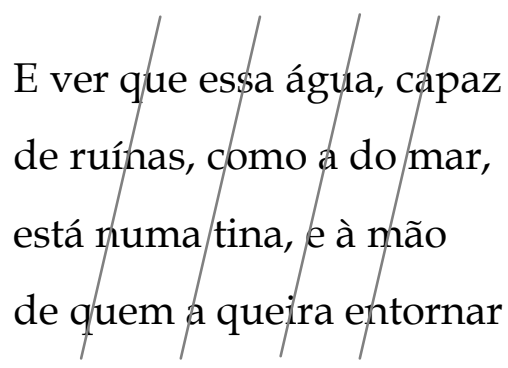

Como seja: agora um dique

<domina> detém, de (simples madeira)

defunta

$<$ a $>$ uma água morta que viva

arrebentava reprêsas

a banheira
e uma tina circunscreve
exposto a que alguém derrame,
o mar de água que ele era,
sem confins, mar de água mangue ${ }^{406}$.

406 Damos aqui o texto definitivo das duas primeiras e das duas últimas estrofes, às quais nos referiremos mais detidamente em nossa análise. As duas primeiras: Quem quer que o veja defunto/havendo-o tratado em vida,/pensará: todo um alagado/coube aqui nessa 
Entre a primeira versão e a versão publicada, observa-se uma mudança de domínio nocional por meio do qual o comendador morto é representado. Tal mudança é o enfraquecimento da noção de movimento em prol da noção de quantidade, através de uma cadeia de reformulações. Na primeira versão, que corresponde ao texto datilografado e que, acima, está em caracteres maiores, temos as seguintes identificações:

Comendador vivo $=$ rio $\left(1^{\mathrm{a}}\right.$ estrofe $)$, água sedenta $\left(2^{\mathrm{a}}\right.$ estrofe $)$, água desrespeitadora de represas (penúltima estrofe), água capaz de ruínas (última estrofe).

Comendador morto $=$ poço $\left(1^{\mathrm{a}}\right.$ estrofe $)$, água estagnada $\left(2^{\mathrm{a}}\right.$ estrofe $)$, água detida por um dique (penúltima estrofe), água contida em uma tina (última estrofe).

Pode-se observar aí sobretudo uma oposição entre movimento (comendador vivo) e imobilidade (comendador morto), tal como o paradigma rio/poço explicita ${ }^{407}$. Por sua vez, no poema publicado, temos as seguintes identificações:

Comendador vivo $=$ alagado $\left(1^{\mathrm{a}}\right.$ estrofe $)$, preamar $\left(2^{\mathrm{a}}\right.$ estrofe $)$, água que arrebentava represas (penúltima estrofe), água sem confins (última estrofe).

bacia.// Restos de banho, água choca,/na banheira do salão,/sua preamar permanente/se empoça, em toda acepção. As duas últimas: Como seja: agora um dique/detém, de simples madeira,/uma água morta que, viva,/arrebentava represas. // E uma banheira contém,/exposto a que alguém derrame,/todo o mar de água que ele era,/sem confins, mar de água mangue.( Obra completa, op. cit., p. 317 - 318).

407 A identificação do rio com o movimento e do poço com a imobilidade pode ser constatada, entre outros, no poema "Rio e/ou poço" (Obra Completa, op. cit. pp. 251252). 
Comendador morto = bacia $\left(1^{\mathrm{a}}\right.$ estrofe $)$, água empoçada $\left(2^{\mathrm{a}}\right.$ estrofe $)$, água detida (penúltima estrofe), água em uma banheira (última estrofe).

Nesse caso, constata-se sobretudo uma oposição, desencadeada pelo paradigma "alagado/bacia", em termos de quantidade, entre o comendador vivo - excesso de água - e o comendador morto - escassez de água -, sem que se abandone a oposição baseada na noção de movimento, que, no entanto, se torna secundária. Essa acentuação do domínio nocional quantitativo ocorreu, como se pode observar, através das seguintes operações de substituição:

rio $\rightarrow$ alagado

água sedenta $\rightarrow$ água invasora $\rightarrow$ enchente $\rightarrow$ preamar

água capaz de ruínas $\rightarrow$ água sem confins

poço $\rightarrow$ restos de banho morno $\rightarrow$ bacia

água estagnada $\rightarrow$ água entorpecida (murcha, poça) $\rightarrow$ resto de banho (água choca, empoçada)

água contida numa tina $\rightarrow$ água circunscrita [numa banheira] $\rightarrow$ água contida em uma banheira

A maior ênfase na noção de quantidade, em detrimento da noção de movimento, na diferenciação entre o comendador vivo e o comendador morto está ligada a uma modalização mais sarcástica dos enunciados, já que, assim, o comendador morto é representado, depois das reformulações, ainda mais diminuído. A noção de quantidade torna mais notória, no poema, a crítica social por meio da vituperação, pois que, segundo o sarcasmo do poema, em vida, tais comendadores 
ocupavam (possuíam) grandes espaços de terra e, agora, mortos, ocupam (possuem) o exíguo espaço de seu caixão.

Se a crítica social era o objetivo inicial do poema - e, de fato, como bem afirmou Sebastião Uchoa Leite, o comendador é "um emblema de classe" 408 - vemos que ela somente se torna mais precisa com a operação reformulativa que explicita metaforicamente a posição social do comendador enquanto grande proprietário de terras.

${ }^{408}$ LEITE, Sebastião Uchôa. Crítica de ouvido. São Paulo: Cosac e Naify, 2003, p. 84. 


\section{4. Do metafísico ao sensual: reformulações do poema "Escritos com o corpo"}

A análise de um outro manuscrito mostra, diferentemente do exemplo anterior, como certas intenções de significação podem, em João Cabral, ser completamente abandonadas depois de um intenso exercício de reformulação. Referimo-nos ao manuscrito da primeira parte de "Escritos com o corpo", que ocupa os fólios 57 e 58 recto do da pasta Pi. Serial, e que transcrevemos por inteiro a seguir. Analisaremos, porém, somente as reformulações referentes à última estrofe, que verdadeiramente tem interesse genético. Uma cópia fotográfica do manuscrito pode ser encontrada no anexo 2. A transcrição é avançada para a página seguinte por uma questão de legibilidade. 


\section{ESCRITO COM O CORPO}

<Ela> Tem uma tal composição <,>

construída

e tão bem travada sintaxe,

que só se pode apreendê-la

em conjunto: nunca em detalhes.

Não se vê nenhum termo, nela,

sobre que

em que a atenção mais se retarde,

e que, por mais significante,

exclusivo

possua, ele só, sua chave.

Nem é possível dividi-la

igual que a

eømø uma sentença, em partes,

e tampouco

nela

ainda menos, de seu sentido

menos, do que é seu sentido

se conseguir uma paráfrase.

E assim como, apenas completa,

ela é capaz de revelar-se,

apenas

também, sé um corpo completo

tem, para captá-la-acuidade

de captá-la, faculdade 
Apenas um corpo completo

Sé um corpo completamente

e sem dividir-se em análise,

será capaz do

poderá esse corpo a corpo

necessário a quem, sem desfalque,

queira apreender os sentidos

carne

que se contêm na sua frase:

trindade

que é corpo mais alma mais gesto,

três dimensões de uma só carne. frase

queira apreender os sentidos

que se contêm na sua frase:

todas as versõe desse corpo, versões possivivis

as dimerpsões de uima só carne.

queira ap.[reender] os sentidos

entranhados no corpo frase:

todas as versões, as pessoas não contáveis

não contáveis dessa trindade

as versões que ponde conter

que existem em

entranhadas eempactas, no corpo frase,

as dimensões que pode haver ter

[ileg.] pessoas [ileg.] as pessoas de sua trindade

as dimensões

quejra apreender as versões,

os sentidos de sua frase:

tudo \&que pode se \&onter,

sentidos

queira apreender os sentides versões

como em

nela entranhados emsua frase

versões

ou todas as [ileg.] desse corpo

dimensões possíveis

as dimensões de uma só carne. 
Antes, uma palavra sobre o título. Acreditamos que a mudança do singular Escrito com o corpo para o plural Escritos com o corpo, da qual não há traço manuscrito, tendo sido efetuada bem tardiamente, está diretamente ligada à mudança do título de Poesia partida em quatro para [Poesia] Serial da qual também não temos traço algum. Com efeito, com o título no singular o poema seria homogêneo, pois formaria um só texto de conteúdo erótico ([poema] escrito com o corpo), dividido em quatro partes correspondentes, cada uma, a uma maneira de representação do corpo feminino (o corpo-frase, o corpo-tela, o corpoveste, o corpo-memória). No plural, porém, o título indica que cada um dos segmentos ([poemas] escritos com o corpo), ainda que tratando do mesmo tema, pode ser, tomado como uma série autônoma.

A primeira parte ou série de "Escritos com o corpo" é calcada na metáfora que identifica o corpo da mulher com uma frase coesa que possui elementos indissociáveis, e que somente é apreensível como um todo ${ }^{409}$. O comentário de Antonio Carlos Secchin, nesse sentido, é preciso:

Descrevendo a mulher, João Cabral endossa o tipo de linguagem que ela libera, e os termos se entrelaçam de maneira a se tornarem indistintos: são duas categorias que se implicam dialeticamente, a partir de noções comuns de "completude", "inteireza", "indecomponibilidade". 410

Vejamos, pela leitura do manuscrito, uma das tentativas de representação da coesão do corpo feminino. Na primeira versão da última estrofe do poema temos:

409 Tal corpo, para ser apreendido (bem entendido, para ser possuído sexualmente), solicita, conforme se lê no poema, um corpo também completo, "sem dividir-se em análise".

${ }^{410}$ SECCHIN, Antonio Carlos. João Cabral: a poesia do menos, op. cit. p. 201. 
[A quem] queira apreender os sentidos que se contêm na sua frase:

que é corpo mais alma mais gesto, três dimensões de uma só carne.

A identificação do corpo feminino com uma frase é reforçada pela rima toante frase/carne. Os sentidos da frase são comparados com as três "dimensões" indissociáveis de uma pessoa: "corpo mais alma mais gesto", e gesto pode perfeitamente significar movimento do corpo, atitude. O autor, portanto, lança mão explicitamente de um vocabulário metafísico para representar a unidade da mulher, através do imagem da união entre corpo e alma.

Com uma primeira reformulação da estrofe, abandona-se a representação metafísica da unidade entre corpo e alma, substituindo-a por uma representação teológica, em referência explícita ao dogma cristão que unifica, em um só Deus, o Pai, o Filho e o Espírito Santo. Essa referência já é pensada pelo autor quando, à margem direita do fólio, ao lado a última estrofe do poema, João Cabral escreve "trindade". A reformulação é ensaiada logo abaixo do texto datilografado, nestes termos:

[A quem] queira apreender os sentidos entranhados no corpo frase: todas as versões, as pessoas não contáveis não contáveis dessa trindade.

A rima carne/frase, da primeira versão, torna-se o sintagma substantivo corpo frase, preservado no texto publicado. Mas os elementos metafísicos corpo, alma, gesto devêm as pessoas não contáveis dessa trindade. Não contáveis, bem entendido, porque a trindade é ao mesmo tempo trina e una, segundo a doutrina cristã. $\mathrm{O}$ que se busca aqui é ainda a representação do caráter ao mesmo tempo múltiplo e 
uno do corpo da mulher. A referência, porém, ao mistério da trindade será logo depois deixada de lado com esta nova reformulação, que busca ainda exprimir a coesão dos sentidos da carne-frase feminina:

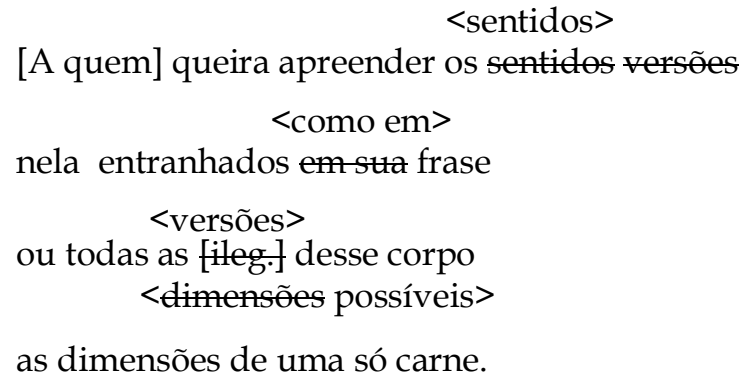

O autor abandona completamente as formulações metafísica e a teológica, mas consegue um texto bastante vago no que diz respeito à representação da indecomponibilidade do corpo feminino: "todas as versões desse corpo/as dimensões de uma só carne". De fato, não se encontra nessa nova formulação nenhuma símile que represente a unidade da múltipla carne da mulher, ideia antes contida na imagem da união entre corpo e alma, na versão primitiva, e na imagem do mistério da trindade, na segunda versão.

Ora, no texto definitivo encontra-se outro domínio nocional:

[A quem] queira prender todos os temas que pode haver no corpo frase: que ela, ainda sem se decompor, revela, então, em intensidade.

Não existe nenhum traço manuscrito, no arcevo do poeta, da mudança. De qualquer forma, verifica-se a ausência total de um símile da multiplicidade una, ou da unidade múltipla, como havia nas duas primeiras versões. A ideia de indecomponibilidade do corpo permanece, mas apresentada diretamente ("sem se decompor"), à qual 
é associada uma imagem erótica: "revela, então, em intensidade", quer dizer, a mulher desnuda suas íntimas partes enquanto carne (e explicita seus temas, enquanto frase). A ruptura com as primeiras representações é notável. Num primeiro momento, a coesão da carne se expressava por uma imagem metafísica ("alma mais corpo mais gesto"), que se tranformou, posteriormente, numa imagem teológica ("as pessoas não contáveis dessa trindade" ${ }^{\prime \prime}$. Em um terceiro momento, essas representações supra-sensíveis cedem o passo a uma formulação pertencente a um domínio nocional propriamente oposto, o da sensibilidade, exatamente o da sensibilidade sexual. 


\section{5. Do estético ao político: o manuscrito do poema "Graciliano Ramos:"}

A análise que faremos a seguir visa mostrar como a instabilidade do poema que se faz - e que leva à sua modificação constante, mesmo que já inteiramente composto, mas ainda não acabado - atinge não somente somente certas zonas semânticas locais, como nos exemplos acima, mas a própria estrutura do texto. $\mathrm{O}$ documento em questão é o manuscrito do poema "Graciliano Ramos:" que ocupa os fólios 49-52 recto da pasta Pi. Serial. Em cada recto encontram-se duas estrofes do poema, que é constituído, no total, por oito. As reescritas, que são feitas sobre um texto datilografado, ocorreram em ocasiões diferentes, a lápis e a caneta de tinta azul escura, o que adiante detalharemos. Transcrevemos, a seguir, o manuscrito, observando que a numeração das estrofes é de nossa iniciativa e serve apenas como orientação no comentário que se seguirá à transcrição. Uma cópia fotográfica do manuscrito pode ser encontrada no anexo 3 . 


\section{GRACILIANO RAMOS:}

1. Falo somente com o que falo:

com as mesmas vinte palavras

girando ao redor do sol

que as limpa do que não é faca:

2. de toda essa crosta viscosa,

resto de janta abaianada,

que fica na lâmina e cega

seu gosto de cicatriz clara. ${ }^{411}$

${ }^{411}$ Pasta Pi. Serial, fólio 49. A pequena reformulação contida nessa estrofe foi feita a lápis, ou seja, na primeira campanha de reescrita. 
3. Falo somente do que falo:

do seco e de suas paisagens,

Nordestes, debaixo de um sol

que por lá é do mais vinagre:

ave de rapina, vinagre:

reduz tudo ao espinhaço

4. que as reduz a seus caules secos

e seca o que é pura folhagem

e seca o que é apenas folhagem,

folha prolixa, folharada

onde possa esconder-se a fraude. ${ }^{412}$

412 Pasta Pi. Serial, fólio 50. As reformulações contidas neste fólio foram feitas a lápis, na primeira campanha de reescrita. 
5. Falo somente por quem falo:

por quem existe nesses climas

condicionados pelo sol,

pelo gavião e outras rapinas:

6. de onde são os solos inertes

de situações e de caatingas

condições ${ }^{413}$

onde só cabe cultivar

o que é sinônímico de míngua. ${ }^{414}$

7. Falo somente eømø falo: com o estilo dessa estação

própria do mineral, do sol

e do meio-dia, o verão:

8. e própria dos solos inertes,

de difícil veggetação,

da piçarra, da areia frouxa

e outros cimentos do Sertão.

9. Falo somente por quem falo

por quem existe nesses climas

condicionados pelo \$ol,

pelo gavião e outras rapinas:

10. e própro dos solos inertes

de certas vidas e caatingas

das situaçôes e das caatingas

onde só cabe cultivar

o nada e sua sinonímia. ${ }_{416}$

$413 \mathrm{O}$ acréscimo "<condições>" foi feito à margem a lápis, na primeira campanha de reescrita.

${ }^{414}$ As duas estrofes foram acrescidas com caneta de tinta azul escura, portanto na segunda campanha de reescrita

415 Reformulação feita a lápis, na primeira campanha de reescrita.

416 As duas estrofes foram escritas a lápis, na primeira campanha de reescrita. 
pra

11. Falo sòmente para quem falo:

quem sofre dêsses sonos mortos

e precisa um despertador

acre, como o sol sobre os olhos:

quando o sol é

12. que é um sol ácidoe estridente,

a contra-pêlo e imperioso

e bate nas pálpebras como

se bate numa porta a socos. ${ }^{417}$

417 Pasta Pi. Serial, fólio 52. As reformulações foram efetuadas a lápis, na primeira campanha de reescrita. 
O texto foi retomado em duas campanhas diferentes: à primeira correspondem as reformulações feitas a lápis, e, à segunda, as reformulações efetuadas a caneta, conforme indicamos em notas à transcrição. Considerando-se que há ainda algumas pequenas mudanças do texto reformulado na última campanha com relação ao texto publicado, conclui-se que o poema foi retomado ao menos uma vez. As estrofes 9 e 10 e as estrofes 5 e 6 são, nessa ordem, reformulações das estrofes 7 e 8, conforme nossa numeração. A seguir listamos o conjunto de reformulações efetuadas, levando em conta também o texto publicado.

A) essa $\rightarrow$ uma (estrofe $\left.n^{\circ} 2\right)$

B) ave de rapina, vinagre $\rightarrow$ que por lá é do mais vinagre $\rightarrow$ ali do mais quente vinagre (estrofe $\mathrm{n}^{\mathrm{o}} 3$ ).

C) as reduz a seus caules secos $\rightarrow$ reduz tudo ao espinhaço (estrofe $n^{\circ}$ $4)$.

D) seca o que é apenas folhagem $\rightarrow$ seca o que é pura folhagem $\rightarrow$ cresta o simplesmente folhagem (estrofe $\left.n^{\circ} 4\right)$.

E) como $\rightarrow$ por quem (estrofes $n^{\circ} 7$ ). Esta reformulação acaba por levar à substituição das estrofes 7 e 8 pelas estrofes 9 e 10 e à substituição destas pelas de $n^{\circ} 6$ e 7 .

F) e próprio dos solos inertes $\rightarrow$ de onde são os solos inertes $\rightarrow$ e onde estão os solos inertes (estrofes $n^{\circ} 10$ e 6).

G) de situações e das caatingas $\rightarrow$ de certas vidas e caatingas $\rightarrow$ de situações e de caatingas $\rightarrow$ [de] condições [e de caatingas] $\rightarrow$ de tantas condições caatingas (estrofes $\mathrm{n}^{\mathrm{o}} 10$ e 6 ).

H) para $\rightarrow$ pra $\rightarrow$ para $\left(\right.$ estrofe $\left.n^{\circ} 11\right)$. 
I) um sol ácido e [estridente] $\rightarrow$ que é quando o sol é [estridente] (estrofe $\left.n^{\circ} 12\right)$.

Com exeção das reformulações $\mathbf{D}, \mathbf{E}$ e $\mathbf{H}$, todas as outras seguem dois paradigmas contrários: as substituições A e C operam uma passagem da noção de determinação (essa [crosta viscosa]; reduz tudo a seus [das paisagens] caules secos) para noção de indeterminação (uma [crosta viscosa], reduz tudo ao espinhaço], reforçando, assim, no primeiro caso, o caráter indistinto do excesso a ser eliminado do material linguístico, e, no segundo caso, a força do efeito da seca sobre a paisagem nordestina. As reformulações B, F, G e I, ao contrário, operam uma passagem do indeterminado ao determinado, através do acréscimo de formas temporais, espaciais e de quantidade: "ali" (B), “onde" (F), "tantas' (G), "quando" (I), tornando mais precisa, assim, a referência ao Nordeste e à sua gente.

O conjunto de reformulações $\mathbf{D}$ mostra como é através de uma cadeia de substituições que Cabral alcança um certo experimentalismo gramatical. Depois da seguinte operação de substituição:

\section{apenas folhagem $\rightarrow$ pura folhagem}

o escritor, com uma segunda reformulação, substantiva um advérbio com a construção do sintagma “o simplesmente folhagem". Algo semelhante acontece no conjunto de reformulações G. O texto inicial, que distingue, sob um mesmo solo, as situações humanas e a vegetação do Sertão, acaba por ser transformado a um tal ponto que o humano (situações) e o vegetal (caatinga) forma um só sintagma pela adjetivação de "caatinga" (tantas condições caatinga).

As reformulações $\mathbf{H}$ (para $\rightarrow$ pra $\rightarrow$ para), são curiosas. A motivação da substituição para $\rightarrow$ pra diz respeito à coerção da métrica: 
com "para", o verso teria nove sílabas, mas como o autor impôs-se, preponderantemente, o octossilábico, a reformulação foi operada e adotou-se "pra". A questão é: por que o autor hesitou e efetuou uma nova substituição voltando à opção "para", no texto publicado? Devido a uma outra coerção auto-imposta por João Cabral de Melo Neto, a recusa do vocabulário próprio da oralidade, que é o registro mesmo da forma "pra". Assim, vê-se que dentre as diversas coerções que guiam o fazer cabralino, algumas tem ascendência sobre outra. No caso, a recusa da oralidade se sobrepõe à metrificação rígida.

A reformulação E é a que tem maior interesse genético, uma vez que a substituição como $\rightarrow$ por quem acaba por levar uma reestruturação do poema. Antes das reformulações, tínhamos um poema estruturado a partir destes quatro enunciados:

1. Falo somente com o que o falo

2. Falo somente do que falo

3. Falo somente como falo

4. Falo somente para quem falo

Com as modificações temos:

1. Falo somente com o que falo

2. Falo somente do que falo

3. Falo somente por quem falo

4. Falo somente para quem falo

Como interpretar a mudança estrutural? Para propor uma hipótese, começaremos por fazer uma menção à leitura, feita por dois críticos, do texto publicado. Primeiro, a de Luiz Costa Lima. Nas palavras do crítico:

A rigorosa construção [do poema "Graciliano Ramos:"] se sustém sobre quatro pilastras, assim enunciadas: falo somente com o que falo, do que falo, por quem falo, para quem falo. [...] A primeira diz do 
material usado, o que se aplica tanto ao autor de Vidas secas, quanto a Cabral, desde seu livro de estréia. Já a matéria "do que falo", é isocrônica à primeira, pois a participação com o Nordeste se dá, antes de tudo, pela constituição do tecido da linguagem. [...]

As afirmações 3 e 4 formam o lado anverso quanto às duas precedentes. Enquanto 1 e 2 tratam do material utilizado e da matéria que refere, 3 e 4 completam-lhes indicando o trânsito que àqueles se assegura: 3. Falo somente por quem falo, 4. Falo somente para quem falo. 418

Assim, para o crítico, o poema é como uma construção arquitetônica, erguida sobre "quatro pilastras", das quais as duas primeiras (com o que falo e do que falo), constituem o dado linguístico (material e máteria) de que é feito o poema, e as outras duas (por quem falo, para quem falo) o dado de realidade para onde se dirige o poema.

O segundo comentário que gostaríamos de referir é o de Abel Barros Baptista. Para o crítico, na medida em que o título do poema pode ser lido tanto como uma "didáscalia", quanto como um "vocativo", sendo impossível, portanto, distinguir quem é referido pelo "EU”, o texto acaba por constituir uma "unidade poética" entre João Cabral e Graciliano Ramos. Dito isso, o crítico interpreta nos seguintes termos a estrutura do poema:

Esta unidade poética assenta em quatro aspectos, que organizam todo o poema através da repetição da diferença, por variação da preposição, do primeiro verso: "Falo somente com o que falo/do que falo/por quem falo/para quem falo". É uma discriminação rigorosa da atividade poética: definição do meio - as mesmas vinte palavras -, do objeto - o seco e suas paisagens - e do destinatário, este definido em duas instâncias, aquele em nome de quem se fala - por quem - e aquele sobre quem essa fala pretende atuar - para quem. ${ }^{419}$.

418 LIMA, Luiz Costa, Lira e antilira, op. cit., p. 325

419 BAPTISTA, Abel Barros, O livro agreste, op. cit., p. 93. 
Vê-se que como Luiz Costa Lima, Abel Baptista também acentua o caráter "rigoroso" da composição. Mas se Luiz Costa Lima se refere a uma construção arquitetônica ("sobre quatro pilastras") e a uma relação das partes como uma relação entre os dois lados de uma moeda ("por quem falo" e "para quem falo" seriam o "anverso" de "com o que falo" e "do que falo"), Abel Baptista, por sua vez, fala de uma "discriminação rigorosa" de quatro aspectos da atividade poética, muito semelhantemente ao que escreveu Antonio Carlos Secchin sobre o poema, quando o vê calcado em quatro "aspectos distintos e complementares do ato de comunicação" ${ }^{420}$. Com estrutura tão coesa, una, completa, é de se pensar que o poema foi, de fato, concebido e realizado arquitetonicamente. Mas a leitura do manuscrito mostra que, se concepção arquitetônica houve, o projeto original teve de ser revisto durante os trabalhos no canteiro da página.

Como vimos, comparando-se a versão inicial com a versão final, nós temos a seguintes operações de substituição, considerando apenas os quatros elementos fundamentais da estrutura semântica do poema:

\section{Falo somente com o que falo $\rightarrow \varnothing$}

Falo somente do que falo $\rightarrow \varnothing$

\section{Falo somente como falo $\rightarrow$ Falo somente por quem falo}

\section{Falo somente para quem falo $\rightarrow \varnothing$}

Ou seja, uma das "pilastras" foi demolida, depois de erguido o edifício-poema, e substituída por outra. E mais importante: antes, era incluído, entre os elementos básicos da fala do "Eu", o "como se fala",

${ }^{420}$ SECCHIN, Antonio Carlos, João Cabral: a poesia do menos, op. cit., p. 197. 
quer dizer, seu estilo, que se caracteriza como claro e seco, já que seu símile é o verão e o solo nordestinos.
Falo somente como falo; com o estilo dessa estação própria do mineral, do sol e do meio-dia, o verão:
e própria dos solos inertes de difícil vegetação, da piçarra, da areia frouxa e outros cimentos do Sertão.

O "como falo" representava, portanto, na primeira versão do poema, o caráter propriamente estético da fala de Graciliano Ramos/João Cabral. Ora, constituído o poema dessa maneira, a partir do material utilizado (Falo somente com o que falo), do objeto representado (Falo somente do que falo), do estilo (Falo somente como falo) e, finalmente, do destinatário (Falo somente para quem falo), a primeira versão também descreveria o circuito completo da comunicação literária. Assim, o que os críticos vêem na versão definitiva, ou seja, uma estrutura rigorosa da atividade poética ${ }^{421}$, já existe na primeira versão: ao material linguístico, ao referente e ao modo de dizer o referente pela linguagem, se acrescentaria o "para quem falo", quer dizer, a quem se destina o texto.

É curioso que Cabral substitua o aspecto estético, a "função poética" da linguagem ("como falo"), pelo aspecto político ("por quem falo"), tornando o escritor um "porta-voz" da sociedade pobre nordestina. Por que o fez o poeta?

\footnotetext{
421 Vimos acima que Abel Baptista Barros lia, na versão final do poema, "uma discriminação rigorosa da atividade poética", interpretando, de maneira esdrúxula, o "por quem falo" como "destinatário" definido numa instância específica, "aquele em nome de quem se fala". Parece-nos um verdadeiro abuso usar a palavra "destinatário" para definir aquele que é representado pelo poeta.
} 
A questão do engajamento - o falar pelo povo pobre do Nordeste - é extremamente importante na obra de Cabral, como o provam seus textos que tematizam a miséria nordestina, sobretudo Morte e vida severina. Porém a autor via muito ceticamente essa função política de sua poesia, na medida em que seus textos que tratam da realidade sertaneja não poderiam veicular entre os próprios sertanejos, conforme ele mesmo afirma numa entrevista:

Eu acredito que esses poemas $[O$ rio $e$ Morte $e$ vida severina] não cheguem, vamos dizer, ao interior de Pernambuco, onde o sujeito está acostumado ao romance de cordel, mas ao público de classe média têm chegado. Você sabe que Morte e vida severina continua sendo levada? Ainda agora [1994] está sendo levada na Ilha do Governador por esse teatro da Terceira Idade. E chegou até na televisão. Mas eu não creio que o sertanejo se interesse por Morte e vida severina. Tem gente do povo que se interessa por Morte e vida severina e tem gente que é povo para quem Morte e vida severina não diz nada. Há muitas camadas do povo, principalmente num país como o nosso de analfabetismo e falta de instrução. ${ }^{422}$

Esse ceticismo quanto à efetividade do engajamento político, na medida em que este, no caso de Cabral, como bem observa Thaís Toshimitsu "esbarra nas consequências das condições de subdesenvolvimento do país" 423 , talvez seja a causa da ausência do "por quem falo" na estrutura original do poema "Graciliano Ramos:"

Mas a posterior inclusão do engajamento, substituindo o aspecto estético, talvez se deva a um problema... estilístico. O "por quem falo" não poderia ter sido simplesmente acrescido ao poema, pois havia a coerção do número quatro - todos os poemas de Serial foram pensados originalmente como "partidos em quatro". Ora, que ele tenha substituído o "como falo" - e não um outro segmento do poema -

422 "O pedreiro do verso", entrevista a José Geraldo Couto. Folha de São Paulo (Mais!), 22/05/1994.

${ }^{423}$ TOSHIMITSU, Thaís Mitiko Taussig, O rio, a cidade e o poeta,cit., p. 130. 
aconteceu, quem sabe, pelo fato de o estilo ("como falo") estar de certa forma já descrito na estrofes que consideram o material ("com o que falo"). De fato, a clareza do "estilo do verão" se anuncia na primeira parte por meio da imagem das palavras girando "ao redor do sol". Havia, portanto, uma certa redundância entre o "com o que falo" e o "como falo". Mas não uma redundância completa, pois o caráter seco e duro do estilo, legível no símile "cimentos do Sertão", está ausente no primeiro segmento. Assim, a mudança estrutural como falo $\rightarrow$ por quem falo, se sana a ausência do importante aspecto político da literatura, perde em precisão descritiva, pois deixa de lado aspectos estilísticos da fala, justamente sua secura e dureza. 


\section{Capítulo 2. O dossiê de $A$ educação pela pedra}

\section{1. Os documentos genéticos}

O livro A educação pela pedra é considerado o mais “arquitetônico" de João Cabral de Melo Neto. Vários estudos já foram feitos que descrevem a "estrutura geométrico-matemática" do livro ${ }^{424}$. Tal estrutura seria fruto, segundo um dos comentadores, de um “planejamento racional, como intenção que o conduz à domação da força criadora caótica, ao mesmo tempo que ordenadora do mundo do caos e da pobreza" 425 .

Esse "planejamento racional", ou seja, a concepção e realização arquitetônicas do livro, teria sido uma vez mais comprovada com a existência de uma "planta baixa" da obra (ver anexo 9), tal como denomina Antonio Carlos Secchin um documento genético por ele publicado e rapidamente comentado na revista Colóquio-Letras ${ }^{426}$. Nas palavras do crítico:

\footnotetext{
424 Por exemplo, entre os mais recentes, o texto de Antonio Lázaro de Almeida Prado que desvela os "módulos compositivos" do livro. Ver "Rosa tetrafoliar: uma leitura de A educação pela pedra a partir de seus módulos poéticos-gerativos in Revista Eletrônica de Humanidades http://publicacoes.unigranrio.edu.br/index.php/reihm/article/viewFile/34/72. 425 TOSHIMITSU, Thaís Mitiko Taussig, O rio, a cidade e o poeta, p. 184.

426 Trata-se de um número (157/158) dedicado ao poeta, intitulado Paisagem tipográfica. Homenagem a João Cabral de Melo Neto (1920 - 1990), julho/dezembro de 2000.
} 
O documento [...] atesta, de modo inequívoco, o rigoroso planejamento que o poeta desenvolvia para impedir que uma obra fosse apenas um conjunto mais ou menos aleatório de textos. Assim, percebe-se uma vontade ordenada que se traduz numa espécie de "planta baixa" de $A$ educação pela pedra, tanto nos aspectos gerais quanto ao nível da microcomposição de cada texto. ${ }^{427}$

Esse juízo deve ser relativizado. Com efeito, o documento publicado por Secchin, e que ele nomeia de "planta baixa", não é, propriamente falando, uma "planta baixa". Esta, em arquitetura, se desenha para servir de orientação na execução do projeto, portanto antes dos trabalhos do canteiro. Esse caráter cronológico, consequência de uma lógica de antecipação, por meio do desenho, do trabalho de erguimento, é bem enfatizado pelos arquitetos, por exemplo, Adolfo Morales de los Rios Filho:

As plantas são, de maneira geral, as projeções horizontais do edifício. [...] O traçado de planta é a tarefa mais importante que cabe ao arquiteto durante a elaboração do projeto. Na composição arquitetônica não há fantasia, mas lógica. Começa-se pela planta e termina-se com a elevação. ${ }^{428}$

Ora, a "planta", publicada por Secchin, foi desenhada depois da composição do livro. De fato, há um conjunto de documentos genéticos da obra, localizável na Fundação Casa de Rui Barbosa, intitulado Pi. A educação pela pedra 1, que é anterior à "planta", contendo 94 fólios, onde se encontram a totalidade dos poemas de A educação pela pedra, inteiramente compostos e com várias reformulações. Mais: a assim chamada "planta" do livro foi confeccionada a partir do documento anterior, sendo, se se segue com a metáfora arquitetônica, não um desenho para o canteiro, mas um desenho do canteiro. Uma comparação

427 SECCHIN, Antonio Carlos. Um inédito de João Cabral. Colóquio-Letras. Paisagem tipográfica. Homenagem a João Cabral de Melo Neto (1920 - 1990), 2000, ns 157/158.

${ }_{428}$ RIOS FILHO, Adolfo Morales de los, Teoria e filosofia da arquitetura, op. cit., p. 395. 
entre os dois documentos esclarecerá a relação - semelhanças e diferenças - entre ambos. Antes, porém, seja dito que completa o dossiê de A educação pela pedra um exemplar do livro, também localizável na Fundação Casa de Rui Barbosa (pasta Pi. A educação pela pedra 2), contendo 109 fólios, e dedicado ao tradutor alemão de Cabral, Curt Meyer-Classon. Nesse exemplar, há a totalidade dos poemas de $A$ educação pela pedra, com algumas correções locais, um índice, semelhante ao do livro publicado, e um bilhete endereçado a Curt Meyer-Classon ${ }^{429}$.

Comparemos, agora, os dois primeiros documentos - de maior interesse genético - referentes à composição do livro.

\footnotetext{
429 Transcrevemos a seguir o bilhete:

Prezado Meyer-Classon, aqui vai uma cópia, que estou mandando ao editor no Rio, de meu novo livro, conforme lhe prometi: Saudo-o cordialmente
} 


\title{
2. 2. A "planta baixa" e a composição dos poemas
}

$\mathrm{Na}$ "planta", a coluna referente aos títulos dos poemas, começando com "A cana de açúcar de hoje" (anexo 9), tem uma ordem que espelha exatamente a ordem dos poemas na pasta Pi. A educação pela pedra 1. Essa ordem dispõe os textos em duas metades; na primeira, os poemas de 24 versos, na segunda, os poemas de 16 versos.

Algumas mudanças de título na "planta" retomam, aliás, modificações já efetuadas na pasta, quais sejam:

\author{
Para a feira \\ Cartazes para $<\mathrm{d}>0$ livro \\ Comendadores jantando \\ Jantar de comendadores \\ mascar \\ Para mastigar com chiclets \\ Bifurcado de outro \\ Habitar o tempo na Caatinga \\ Sebre $<C>/$ c/atar feijão \\ O mar e o canavial \\ Sem falar no verde \\ O canavial e o mar \\ Falando no verde
}

Não nos tardaremos nessas mudanças de título. $\mathrm{O}$ mesmo não acontecerá considerando a primeira coluna de códigos, da esquerda 
para a direita - sempre lendo a "planta" a partir da sequência que começa com o título "A cana de açúçar de hoje. Nessa coluna enumeram-se, como esclarece o próprio poeta, os “tipos de justaposição das U[nidades] e de associações das M[etades]" dos poemas. Essas justaposições e associações não são as mesmas na "planta" e nos outros documentos em questão. Listamos a seguir os poemas que tiveram suas estruturas reformuladas:

1. "A cana de açúcar de hoje". O poema - publicado com o título "A cana de açúçar de agora" -, na "planta baixa" do livro, tem suas duas unidades justapostas por "Rv." ("repetição de verso"), como esclarece o índice do autor ${ }^{430}$. Mas anteriormente, na pasta Pi. A educação pela pedra 1, as duas unidades se relacionavam por "Ep." ("Encadeamento [com] rep[etição] [de] palavras), como se pode ver através da reformulação efetuada no manuscrito:

Hoje num partido, se entrevê pouco

$\mathrm{Na}$ cana de hoje $<,>$ se entrevê pouco ${ }^{431}$

Quer dizer, na versão datiloscrita, o primeiro verso da segunda unidade repete somente o sintagma "se entrevê pouco". Com a alteração, é todo o primeiro da primeira unidade que é repetido no primeiro verso da segunda unidade: “Hoje num partido se entrevê pouco". Acrescente-se que tal verso, na versão publicada, muda para "Agora nos partidos, se entrevê pouco'" (Obra completa, op. cit., p. 353).

2. "Os rios de um dia". O poema tem suas duas metades associadas, na "planta", por meio de uma "C.ca." (conjunção

${ }^{430}$ Na pasta Pi. A educação pela pedra 1, a relação de justaposição, no poema "A cana de açúcar de hoje", é classificada, pelo próprio Cabral, como "R. L. (Repetição linha -1 e 1)". Ver o fólio 2.

${ }^{431}$ Pasta Pi. A educação pela pedra 1, fo 2. 
causal). Antes, porém, as metades se ligavam por "Ep." (encadeamento com repetição de palavras), como se pode verificar através do manuscritos da pasta Pi. A educação pela pedra 1:

Pois isso que êle

Isso/,/ que o rio-define com clareza, ${ }^{432}$

3. "Os reinos do amarelo", por sua vez, tem suas duas metades, na "planta", ligadas por "Ev." ("encadeamento com repetição de verso"). Mas, antes, nos manuscritos do livro, as duas metades se ligavam por "Ep." (encadeamento com repetição de palavras):

Só que prende a vista, mais comum:

Na paisagem da Mata dá, mais comum: ${ }^{433}$

Com associação por Ep., o primeiro verso da segunda metade retomava o primeiro verso da primeira metade, assim formulado e reformulado no manuscrito: "A paisagem da mata / bem que pavoneia/ <possui e ostenta>". Com associação por Ev., o primeiro verso da segunda metade repete exatamente o nono verso da primeira metade, assim formulado e reformulado: "Só que/a vista retém, mais numeroso/<prende a vista, mais comum $>$ ".

4. O poema "The country of the Houyhnhnms" tem suas duas metades ligadas, na "planta", por meio de uma "C. cop." (conjunção copulativa). Na pasta Pi. A educação pela pedra 1, através de "Ep." (encadeamento com repetição de palavras):

$<$ E $>$ Para quando ouvir falar dos Yahoos ${ }^{434}$

432 Pasta Pi. A educação pela pedra 1, fólio 8.

433 Pasta Pi. A educação pela pedra 1, fólio 24.

434 Pasta Pi. A educação pela pedra 1, fólio 32. 
O autor faz a seguinte anotação metalinguística no manuscrito:

Conjunção copulativa. Esse "e" é importante porque contém em si "se necessita"435.

"Se necessita" é uma forma presente no primeiro verso da primeira metade: "Para falar dos Yahoos se necessita".

5. "Habitar o tempo" (ver anexo 6). Na "planta", o poema tem suas duas metades ligadas por uma "C.t." (conjunção temporal). Nos manuscritos, porém, o autor oscila entre a temporal e a adversativa:

Depois que foi

Mas

De volta de [ir?] habitar seu tempo:436

Essa oscilação se torna mais aguda se se tem em mente a nota metalinguística (à qual voltaremos adiante) feita pelo próprio autor, no mesmo fólio:

Conjunção temporal; depois que. Mas poderia ser adversativa. 'Mas de volta de'. Creio que a temporal é melhor". ${ }^{437}$

Essa hesitação não será resolvida com a escolha nem da temporal, nem da adversativa, mas com a escolha de uma conjunção copulativa, como se pode ler no poema publicado:

E de volta de ir habitar seu tempo:438

435 Idem, ibidem.

436 Pasta Pi. A educação pela pedra 1, fólio 36.

437 Idem, ibidem.

438 Obra completa, op. cit., p. 365. 
6. O poema "O regaço urbanizado", por sua vez, tem, na "planta", suas metades ligadas por "Ep." (encadeamento com repetição de palavras), estabelecido através da seguinte reformulação:

Com ruas se arruelando mais em becos

Aqueles bairres antigos de Sevilha ${ }^{439}$

Essa reformulação é acompanhada do seguinte comentário metalinguístico:

E. (encadeamento: a repetição de com ruas liga o poema à [ileg.] parte anterior).

Na primeira versão do poema, que pode ser encontrada na pasta Pi. A educação pela pedra 1, esse encadeamento não existia. Nenhum elemento da parte anterior era retomado, de tal sorte que ambas as partes constituiam, cada, uma unidade e não uma metade. A mudança para o encadeamento implicou toda uma reformulação da primeira quadra do poema, da qual dois versos são substituídos e os outros dois completamente suprimidos:

Aqueles bairros antigos de Sevilha

Com ruas se arruelando mais em becos

criam o gosto do regaço urbanizado.

ou alargando em largos quase pátios,

para quem quer, quando fora de casa,

o resguardo fiel de corpo em quarto.

O dois versos suprimidos são compensados com o acréscimo de outros dois versos no fim da mesma primeira parte:

439 Pasta Pi. A educação pela pedra 1, fólio 38. Na versão definitiva, o verso terá o acréscimo de vírgulas: “Com ruas se arruelando mais, em becos, 
aqueles bairros antigos de Sevilha

fundaram uma urbanização do regaço.

A mudança da justaposição pura para o encadeamento se completou com a reformulação dos dois primeiros versos da segunda parte:

Com ruas se arruelando mais em becos

Aqueles bairros antigos de Sevilha

e alargando mais em largos quase pátios,

criam o gosto do regaço urbanizado:

7. Na assim chamada "planta baixa" do livro, as duas metades do poema "Fábula de um arquiteto" se ligam por uma "C. t." (conjunção temporal). Mas nos manuscritos da pasta Pi. A educação pela pedra 1, as duas metades eram postas em relação por “Ep.” (encadeamento com repetição de palavras):

Até que um dia, o livre o amendontrando,

Tantes livres o encadeando, recuou ${ }^{440}$

O que se repetia na versão prototextual era justamente a palavra "livres", presente no último verso da primeira metade:

por onde livres, ar luz, razão certa.

8. O poema "Catar feijão" (ver anexo 4), na "planta baixa" do livro A educação pela pedra, tem suas duas metades ligadas por uma "C. il." (conjunção ilativa). Nos manuscritos, porém, a segunda metade era justaposta à primeira, retomando-se alguns termos, quais sejam, "catar feijão") :

${ }^{440}$ Pasta Pi. A educação pela pedra 1, fólio 56. No texto publicado, o verso "Até que um dia, o livre o amendrontando" é assim reformulado "Até que, tantos livres o amendrontando" (Obra completa, op. cit., p. 346). 
Ora, nesse catar feijão há um risco:

Certo, nessa forma de catar feijão $\Theta^{441}$

9. "Duas das festas da morte". Na "planta", lê-se que ambas as unidades são "sem ligação" (S. 1.). Na versão datilografada, porém, havia um E. p. (encadeamento com repetição de palavras):

que ela organiza

Piqueniques infantis <que> dá a morte:

Essa mudança é acompanhada da nota "s[em]. ligação: disfarçar o dá a morte.". A ordem de disfarçar o sintagma "dá a morte", era necessária para uma composição puramente justaposta na medida em que ele já estava presente no primeiro verso da primeira unidade, também disfarçado pelo autor:

que ela promove

Recepções de cerimônia <que> dá a morte :

Curiosamente esse disfarce não vingará e o sintagma "dá a morte" figurará, na versão publicada, tanto no primeiro verso da primeira unidade ('Recepções de cerimônia que dá a morte”), quanto no primeiro verso da segunda unidade ("Piqueniques infantis que dá a morte"').

10. No poema "O urubu mobilizado", as duas metades são, na "planta", ligadas por uma “C. ad." (conjunção adversativa). Na pasta Pi. A educação pela pedra 1, as duas metades se relacionam por Ep. (encadeamento com repetição de palavras):

\footnotetext{
${ }^{441}$ Pasta Pi. A educação pela pedra 1, fólio 60. Note-se que o verso “Ora, nesse catar feijão há um risco" é, na versão final, reformulado ligeiramente por "Ora, nesse catar feijão entra um risco:" (Obra completa, op. cit., p. 347.)
} 
Mas no urubu em ação, mesmo funcionário,

No urubu em ação $<,>$ (e no empresário $)^{442}$

Seja notado através do texto publicado que a ligação entre as metades é uma vez mais reformulada, sem que haja traço genético da reformulação, ocorrendo por meio de uma conjunção concessiva:

Embora, mobilizado, nesse urubu em ação ${ }^{443}$.

11. O poema "Na morte dos rios" (ver anexo 7), intitulado originalmente "Nos rios mortos", tem, na "planta", suas duas metades relacionadas por meio de "Ev." (encadeamento com repetição de verso). Nos manuscritos, as duas metades se ligavam por meio de uma “C. ad." (conjunção adversativa):

D no Alto Sertão

Mas desde que na região um rio seca, ${ }^{444}$

12. "Uma ouriça", por sua vez, tem, na "planta", suas duas metades ligadas por "Ep." (encadeamento com repetição de palavras). Na pasta Pi. A educação pela pedra 1, as duas metades são relacionadas por uma “C. ad." (conjunção adversativa):

Se um de longe chega a chegar

Mas $<\mathrm{S}>/ \mathrm{s} / \mathrm{e}$ o de longe lhe chega dentro 445

Assim sendo, observa-se que 12 poemas são concebidos e escritos com certa estrutura de ligação entre suas metades ou unidades, mas são posteriormente reformulados, de tal maneira que o tipo de ligação devém outro. Na medida em que os documentos genéticos da pasta $\mathrm{Pi}$.

\footnotetext{
${ }^{442}$ Pasta Pi. A educação pela pedra 1, fólio 88.

${ }^{443}$ Obra completa, op. c it., p. 339.

444 Pasta Pi. A educação pela pedra 1, fólio 90.

${ }^{445}$ Pasta Pi. A educação pela pedra 1, fólio 92. Note-se que o verso "Se um de longe chega a chegar dentro" é modificado, mais uma vez, na versão final: "Se o de longe lhe chega (em de longe)" (Obra completa, op. cit. p. 346).
} 
A educação pela pedra 1 são anteriores à "planta baixa" publicada por Antonio Carlos Secchin, essa mudança de estruturas problematiza o procedimento arquitetônico e a lógica de antecipação do projeto. Aqui, ao contrário, os trabalhos do canteiro são anteriores e determinam o desenho da planta. Teremos a oportunidade de voltar a essa questão.

Por ora, continuemos a comparação dos manuscritos com a "planta". A segunda coluna de códigos, imediatamente após os "tipos de justaposição das U[nidades] e de associação das M[etades]", e que se grafam "P" $\mathrm{e}$ "-", identificam o textos que versam sobre Pernambuco $(" P)$ e o textos que não o fazem ("-"). Essa divisão é o protótipo da divisão "Nordeste; Não Nordeste" que constitui a macro-estrutura do livro publicado. Não há, nesse caso, diferenças entre os manuscritos e a "planta".

A terceira coluna de códigos determina se os poemas são constituídos por unidades ("U"), podendo cada uma de suas partes ser lida com certa autonomia, ou por metades (" $\left.\mathrm{M}^{\prime}\right)$, sendo cada parte dependente semanticamente da outra. Como pode ser concluído da comparação feita mais acima das estruturas de justaposição e associação, um poema sofre uma modificação nesse sentido, "O regaço urbanizado", que, na "planta", era formado por duas metades ligadas por "Ep." (encadeamento com repetição de palavras), e que, anteriormente, na pasta, era constituído por unidades, já que ambas as partes do poema se justapunham sem ligação. Ou seja, na "planta" há 24 poemas formados por duas unidades e 24 formados por duas metades; nos manuscritos da pasta Pi. A educação pela pedra 1, eram 25 poemas compostos de duas unidades e 23 de duas metades. A reformulação operada sobre o poema "O regaço urbanizado" certamente serviu para tornar o número de U e M iguais. 
A quarta coluna de códigos, da esquerda para a direita, grafados "A 1", "A 2" e "S", diz respeito ao número de versos dos poemas. Na sequência dos poemas de 24 versos, começada com "A cana-de-açucar de hoje" até "Bifurcado de outro", "A 1" designa os poemas compostos de 16 versos + 8 versos, "A 2" designa os poemas compostos de $8+16$, e "S" - que muito provavelmente significa "simétrico" - designa os poemas composto de 12 versos +12 versos. Na sequência que começa com o título "O sertanejo falando", e que contém os poemas compostos de 16 versos, "A 1" designa os textos de 10 versos + 6 versos, "A 2" designa os poemas de $6+10$, e " $\mathrm{S}$ " designa os poemas compostos de 8 versos +8 versos. Não há, nesse caso, diferença entre a pasta Pi. A educação pela pedra 1 e a assim chamada "planta baixa".

Finalmente, a quinta coluna de códigos, imediatamente do lado dos títulos dos poemas, designa, como esclarece o próprio João Cabral, os "tipos de associações entre as semi-partes de cada parte". Também aqui há diferenças entre as associações feitas na primeira versão de alguns poemas e as associações listadas na "planta". Tais poemas são:

1. "A cana de açucar de hoje". Se não há diferença entre a "planta" e os manuscritos no que diz respeito à associação entre as semi-partes da segunda unidade, que é feita por meio de "JR" ("justaposição com repetição de elementos das 2 linha anteriores"), o mesmo não ocorre com a associação das semi-partes da primeira unidade. Neste último caso, na "planta", a associação ocorre por " $\mathrm{E}$ " (encadeamento, com elementos mais distantes do que 2 linhas). Esse era, também, o esquema na versão datilografada; mas ele é substituído temporariamente por "JR", tipo de associação que acaba, finalmente, por não vingar. Mas vale a pena citar os quatro 
versos finais da unidade provisoriamente modificados e a auto-injunção do autor para bem analisar a reformulação:

Não expõe a cana

A cana se esconde, na cana de hoje,

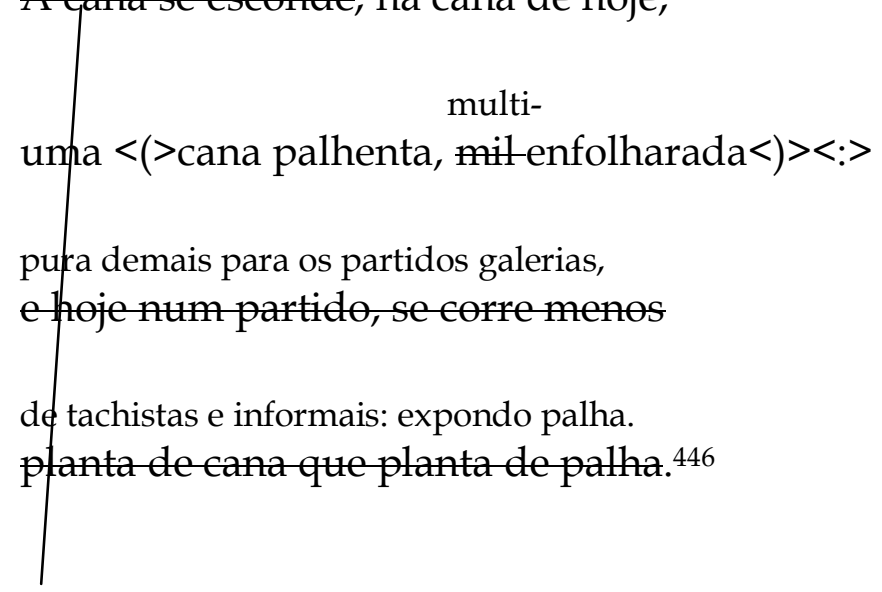

fazer este final uma

ligação: entre a cana

escultura e a cana

mulher, a cana

cana [ileg.] [ileg.] $]^{447}$

Considerando-se a associação com "E" (encadeamento com elementos mais distantes do que 2 linhas), o que é caso da versão prototextual e da versão reformulada, o elemento que se retoma, por meio do sintagma "se esconde", é a ocultação da cana nua nos partidos, presente no primeiro verso “/Hoje/<Agora> nos partidos, se entrevê pouco". Enquanto associação por "JR", o elemento que se retoma das duas linhas anteriores é o aspecto artístico da cana, presente antes no $10^{\circ}$ verso:

sua escultura de razão ou Pevsner;

446 Confira-se a versão definitiva: "A cana se esconde, na cana de agora,/que dá mais palha e evita despalhá-la;/e agora se corre menos, nos partidos,/plantas-de-cana do que plantas-de-palha" (Obra completa, op. cit., p. 354).

${ }_{447}$ Pasta Pi. A educação pela pedra 1, fólio 1. 
e recuperado no $12^{\circ}$

Não expõe a cana, na cana de hoje,

onde "expõe" significa "põe-se à vista como objeto de arte", como se pode confirmar com a posterior menção às galerias de exposição e à pintura du "tachisme":

pura demais para os partidos galerias, de tachistas e informais: expondo palha.

A ligação entre os diversos aspectos da cana (artístico, feminino e enquanto planta), conforme se auto-impõe o autor, é tentada com a reformulação mas abandonada na versão definitiva. Veremos mais adiante as razões desse abandono.

2. "Para a feira do livro" (ver anexo 8). "Na "planta", lê-se que as semi-partes da segunda unidade do poema são associadas por meio de “C" , ou seja, conjunção, no caso, adversativa; porém, na versão anterior, eram ligadas por pura justaposição (“J”):

Mas apesar disso e apesar de tolerante $\quad<<$ (paciente) $>>$ paciente: quem quer o relê e treslêt $\hat{e}^{448}$

3. "Psicanálise do açúcar". Na "planta", lê-se que as duas semipartes da primeira unidade são associadas por ' $R$ ' (justaposição com repetição de elementos das 2 linhas

448 O verso, na versão definitiva ficou: "Mas apesar disso e apesar de paciente" (Obra completa, op. cit., p. 367) 
anteriores). Ora, na versão mais antiga, a ligação se dava por meio de uma conjunção copulativa:

Conhece o nada do pouco que o cristal

E que o branco por fora, que o cobre ${ }^{449}$

4. "Fazer o seco, fazer o úmido". Tanto na versão prototextual, quanto a versão definitiva, as duas semi-partes das duas unidades são associadas, como anota o próprio autor, por meio de "JR" (justaposição com repetição de elementos das 2 linhas anteriores). Mas, no manuscrito, há a seguinte substituição do advérbio na primeira unidade:

Talvez humus

Certo o metal sem sede dessa música ${ }^{450}$

Na segunda unidade temos:

Talvez porque

Certo as gotas dessa música chovida 451

Ou seja, uma mudança de modalidade, passando-se da assertiva para a dubitativa, o que altera completamente a relação entre as duas semipartes de cada metade.

5. “Nos rios mortos" (ver anexo 7), publicado com título “Na morte dos rios". $\mathrm{Na}$ "planta" as duas semi-partes da primeira metade são associadas por "R" (justaposição com repetição de elementos das duas linhas anteriores). Na versão prototextual, a associação se dava por justaposição pura, absoluta ("J"):

\footnotetext{
$449 \mathrm{O}$ verso, na versão publicada, foi um pouco modificado: "Sabe o mínimo do pouco que o cristal". (Obra completa, op. cit., p. 356)

450 Pasta Pi. A educação pela pedra 1, fólio51.

${ }^{451}$ Pasta Pi. A educação pela pedra 1, fólio 52. O verso definitivo ficou: "Talvez as gotas úmidas dessa música" (Obra completa, op. cit., p 340).
} 
Fazendo alto à agressão, nunca invade $\quad<<$ (ocupa $>>$

Grande ausente, não ocupa o rio seco ${ }^{452}$

Com a associação em " $\mathrm{R}$ " retoma-se o paradigma "agressão" presente dois versos atrás:

belicosa

$<$ e $>$ toda $<$ em $>$ sabres, intratável e agressiva,

Assim, mais cinco poemas tem sua estrutura modificada antes da feitura do desenho da "planta", agora no nível da relação entre as semipartes dos textos, o que problematiza uma vez mais o rigor do procedimento arquitetônico. A "planta", de fato, ordena a composição dos poemas, mas ela não orienta, antecipando, a construção deles. Acreditamos ter, com isso, uma prova de quanto o vocabulário da arquitetura pode ser abusivo para a caracterização do procedimento cabralino. Ao menos o vocabulário de uma arquitetura projetual. Porque vemos aqui que os trabalhos do "canteiro" são anteriores à composição do desenho, ou, como dissemos antes, trata-se aqui de um desenho do canteiro. Isso mostra que o livro, no nível micro-estrutural dos poemas, foi concebido e realizado de uma maneira processual e não programática.

452 Pasta Pi. A educação pela pedra 1, fólio 89. O verso, no texto publicado, é: “Faz alto à agressão nata: jamais ocupa" 


\section{3. Reformulações locais}

Vimos, através da comparação dos documentos da pasta Pi. A educação pela pedra 1 com a "planta baixa" do livro, diversas mudanças micro-estruturais operadas pelo poeta, quer dizer, mudanças das relações entre as unidades ou metades dos poemas, e entre as semipartes de algumas unidades ou metades. Além dessas mudanças estruturais, encontram-se também, nos manuscritos, diversas modificações semânticas locais, que dão à luz novas semiotizações dos objetos dos poemas. Não será o caso, aqui, de fazer uma análise detalhada de todas a reformulações. Daremos apenas alguns exemplos por onde seja possível observar o trabalho, efetuado por Cabral, de instauração de representações tanto equivalentes quanto assimétricas com relação às do texto de origem.

Das reformulações equivalentes, podemos dar como exemplo as reescritas da primeira unidade do poema "Para a feira do livro", cujo prototexto damos a seguir. Uma cópia fotográfica do manuscrito pode ser encontrada no anexo 8 . 


\section{PARA A FEIRA DO LIVRO \\ CARTAZES PARA O LIVRO}

\begin{tabular}{|c|c|c|}
\hline & & $\begin{array}{l}\text { Girando } \\
\text { Ao girar nos gonzos, a folha do livro } \\
\text { Ao ser virada }\end{array}$ \\
\hline $2-11$ & $\S$ & $\begin{array}{l}\text { Virando-se, a folha do livro retoma } \\
\text { Ao ser passada, a folha de um livro }\end{array}$ \\
\hline $6-11$ & & $\begin{array}{l}\text { o gesto vegetal que ao vento uma folha, } \\
\text { retema o lânguido vegetal da folha }\end{array}$ \\
\hline 6- 11 & & $\begin{array}{l}\text { um } \\
\text { e } \theta \text { livro se folheia, se desfolheia, }\end{array}$ \\
\hline $3-10$ & & $\begin{array}{l}\text { como ao vento a própria que o doa } \\
\text { tante quante uma árvore se desfelha; }\end{array}$ \\
\hline $2-11$ & & $\begin{array}{l}\text { ao ser virada } \\
\text { virando-se, a folha do livro repete } \\
\text { aoser passada, a folha de um livro }\end{array}$ \\
\hline $7-11$ & & $\begin{array}{l}\text { o roçar e o resmungar de ventos tidos, } \\
\text { repete o rumor de ventes sucedidos }\end{array}$ \\
\hline 6- 11 & & $\begin{array}{l}\text { finge vento na folha da } \\
\text { e nada interpreta o vente na árvore }\end{array}$ \\
\hline $4-10$ & & 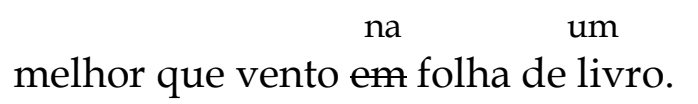 \\
\hline
\end{tabular}


Um breve esclarecimento quanto à numeração feita à esquerda do documento, presente nos mansucritos de todos os textos da pasta $\mathrm{Pi}$. A educação pela pedra 1. Trata-se da contagem efetuada por Cabral do número de sílabas dos versos, cuja métrica ele decompõe irregularmente em dois "hemistíquios". O primeiro algarismo corresponde ao número de sílabas até a primeira pausa e o segundo ao número de sílabas do verso inteiro, o que nos leva, por uma operação de subtração, à quantidade de sílabas do segundo "hemistíquio". O número sempre diz respeito ao verso reformulado, muito embora não corresponda, por vezes, à métrica da versão final publicada. Por exemplo, no sexto verso, o primeiro "hemistíquio" tem 7 sílabas e o verso total tem 11 ("o roçar e o resmungar de ventos tidos"); logo, o segundo "hemistíquio" do verso tem 4 sílabas. Mas na versão publicada, a primeira parte tem 8 sílabas, o verso total 13, e, logo, a segunda parte, 5 sílabas ("fricativas e labiais de ventos antigos").

Agora, com respeito às reformulações semânticas, sempre considerando o manuscrito e a versão definitiva do poema, temos 3 versões diferentes da primeira semi-parte da primeira unidade.

De início, temos:

Ao ser passada, a folha de um livro retoma o lânguido vegetal da folha, e o livro se folheia, se desfolheia, tanto quanto uma árvore se desfolha; ao ser passada, a folha de um livro repete o rumor de ventos sucedidos e nada interpreta o vento na árvore melhor que o vento em folha de um livro. 
A segunda, considerando as reformulações retidas:

Ao girar nos gonzos, a folha do livro retoma

o gesto vegetal que ao vento uma folha,

e um livro se folheia, se desfolheia,

como ao vento a própria árvore que o doa;

ao ser virada, a folha do livro repete

o roçar e o resmungar de ventos tidos,

e nada finge vento na folha da árvore

melhor que vento na folha de um livro.

Finalmente, a terceira, a versão publicada:

Folheada, a folha de um livro retoma

o lânguido e vegetal da folha folha,

e um livro se folheia ou se desfolha

como sob o vento a árvore que o doa;

folheada, a folha de um livro repete

fricativas e labiais de ventos antigos,

e nada finge vento em folha de árvore

melhor do que vento em folha de livro ${ }^{453}$

A comparação entre as três versões mostra que uma mesma intenção permanece, a de mostrar a similitude da sonoridade do vento nas folhas de um livro e da sonoridade do vento nas folhas de uma árvore. Isso se verifica pela permanência, nas três versões, do sintagma "a folha de um (do) livro repete", e o que ela repete é o som do vento na árvore. A representação do som eólico sofre algumas modificações, da seguinte maneira:

${ }^{453}$ Obra completa, op. cit., p. 367. 
rumor de ventos sucedidos<smiles>C1C[Te]1</smiles>

roçar e resmungar de ventos tidos

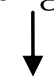

fricativas e labiais de ventos antigos

Essas paráfrases ocorrem por meio de duas relações parasinonímicas de valor metafórico. Na versão datilografada, a representação é ortonímica, expressa pela palavra "rumor". A primeira reformulação mantém, por um lado, a ortonímia, por meio do verbo "roçar" (o som produzido pelo contato do vento com as coisas), e, por outro lado, opera uma personificação fortemente marcada ao associar o som do vento ao "resmungar", ao falar por entre os dentes. A segunda reformulação, por sua vez, abandona completamente a representação ortonímica, mantendo a metáfora personificante, mas agora por meio de conceitos fonemáticos ("fricativas e labiais"). Essa representação do som do vento nas folhas por meio de conceitos fonemáticos, vai de par com uma maior disseminação do fonema /f/, também fricativo e labial, no trecho citado, o que dá um exemplo de como o isomorfismo, isto é, neste caso, a correspondência entre a representação semântica e a representação sonora, pode também ser processual na conduta cabralina. De fato, na primeira versão temos 7 palavras com o fonema /f/: 4 vezes a palavra "folha", a palavra "folheia", a palavra "desfolheia" e a palavra "desfolha". Na segunda versão, 8: 5 vezes a palavra "folha", a palavra "folheia", a palavra "desfolheia" e a palavra "finge". Na terceira versão, onde o poeta lança mão da expressão "fricativas e labiais", o fonema /f/ se repete 10 vezes, nas cinco 
aparições da palavra "folha", nas duas da palavra "folheada", na palavra "folheia", na palavra "desfolha" e na palavra "finge".

Por outro lado, no manuscrito a seguir, podemos ver um exemplo de como as paráfrases produzidas guardam entre si uma relação mais assimétrica do que de equivalência. Referimo-nos ao prototexto da primeira metade de "Na morte dos rios", intitulado originalmente "Nos rios mortos", localizável no fólio 89 recto, da pasta Pi. A educação pela pedra 1. (ver anexo 7). 


\section{NOS RIOS MORTOS}

7 - 11 1. Desde que no Alto Sertão um rio seca,

7 - 11 a vegetação em volta, toda em unhas,

3-11 toda sabres, intratável e agressiva,

abstém invadir

2-11 se esquiva de profanar o leito tumba.

6-9 JR Fazendo alto à agressão, nunca invade ocupa

+ Grande ausente, não ocupa o rio seco,

Calando

não ocupa

de ossos de areia, de uma areia múmia.

7 - 11 o rio de ossos areia, $<\mathrm{d}>$ a areia múmia.

+ Desarmando a agressão nata

melhor um verbo militar

faz alto, < bem> à beira do leito e tumba

Đesarmando a agressão [nata?]

Contendo $a<s>$ agressão nata $<s>$, faz alto à beira

Calande armas

Fazendo alto à agressão, foge de ocupar

as

faz alto bem à beira do leito tumba

Fazende alto à agressão nata, <e> não ocupa 
As expressões em negrito reproduzem as alterações feitas com caneta vermelha; as demais, foram feitas a lápis. Não nos alongaremos sobre essa mudança de instrumentos que prova que o datiloscrito foi retomado em, pelo menos, duas campanhas diferentes de reescrita ${ }^{454}$. Concentrar-nos-emos na reformulação da relação entre a vegetação e o rio seco. Na versão prototextual, o que caracteriza a vegetação é uma ausência respeitosa relativamente ao leito ressecado:

[A vegetação] se esquiva de profanar o leito tumba.

Grande ausente, não ocupa o rio seco,

o rio de ossos areia, a areia múmia.

Essa representação será transformada, e o que então caracterizará a vegetação no texto publicado será um sentimento belígero contido.

[A vegetação] faz alto à beira daquele leito tumba.

Faz alto à agressão nata: jamais ocupa

o rio de ossos areia, de areia múmia.

Mas a passagem de uma representação a outra passa por um intenso trabalho parafrásico - que instaura o domínio nocional militar - feito nas entrelinhas do datiloscrito e abaixo dele. Com relação ao $3^{\circ}$ verso temos:

intratável $\rightarrow$ belicosa (reformulação não retida)

454 Diremos três campanhas. Na primeira, o autor usa lápis e ensaia, abaixo do texto datilografado, uma primeira reformulação do quinto verso ("Desarmando a agressão nata"). Mesmo não se decidindo por essa solução, o autor deixa transparecer, através de uma nota metalinguística ("melhor um verbo militar"), que, pelo menos, está satisfeito com o domínio nocional bélico. João Cabral depois retoma o texto usando, agora, caneta vermelha, e reformula, sempre abaixo do manuscrito, os versos quarto e quinto utilizando noções militares pelas quais se decidira ("faz alto", "desarmando", "agressão", "armas", "foge de ocupar"), sem, no entanto, chegar a uma solução final. Finalmente, ele retoma o texto uma terceira vez, usando novamente lápis, e, a partir das reformulações anteriores, escreve novamente, abaixo das reformulações feitas com caneta vermelha, o quarto e o quinto versos. Observa-se que este último é retrabalhado na parte de baixo do fólio e nas entrelinhas do texto datilografado. 
Com respeito ao quarto verso, temos:

se esquiva de profanar o leito tumba

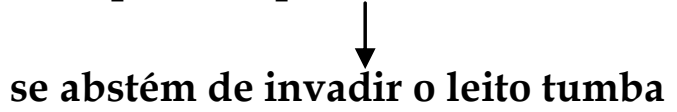

faz alto, < bem> à beira do leito e tumba

faz alto, bem à beira do leito tumba

faz alto, bem à beira

faz alto à beira daquele leito tumba

Com relação ao quinto verso, temos:

Grande ausente, não ocupa o rio seco

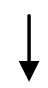

Desarmando a agressão nata

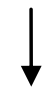

Contendo / $<$ Calando $>/$ a agressão nata,

Contendo / $<$ Calando $>/$ as armas natas

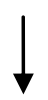

Fazendo alto à agressão, foge de ocupar

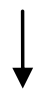

Fazendo alto à agressão nata, nunca invade

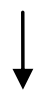

Fazendo alto à agressão nata, não ocupa

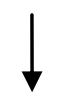

Faz alto à agressão nata e não ocupa

Faz alto à agressão nata: jamais ocupa 
Através dessas reformulações o autor quer ainda figurar o fato de a vegetação não crescer nos rios ressecados. Mas a mudança de domínio nocional - a passagem da passividade respeitosa para o militarismo contido da vegetação com relação ao rio - não pode ser neglicenciada, na medida em que transforma nossa representação da relação entre uma e outro.

Um terceiro e último exemplo de reformulação local mostra como o trabalho parafrásico pode instaurar uma forte diferença semântica entre texto de origem e texto final. Trata-se do manuscrito da segunda metade do poema "Uma ouriça":

4-9 Se um de longe chega a chegar

2. Mas $<\mathrm{S}>/ \mathrm{s} / \mathrm{e}$ o de longe lhe chega dentro

4-10 espinho a espinho, ela se deseriça.

metal armado e hermético

3-10 J Reconverte: o-ncouraçamento côncavo

côncava e

4-10 na carne de antes, eonvexa, propícia

5 - 9 e as molas felinas, para o assalto,

7 - 10 nas molas em espiral, para o abraço. ${ }^{455}$

A principal mudança de representação do objeto do poema - a ouriça - diz respeito à reformulação de sua qualificação quando eriçada ou desriçada. Na versão datilografada, eriçada, a ouriça é "côncava", e,

455 Pasta Pi. A educação pela pedra 1, fólio 92. 
depois de "reconverter" seu aspecto bélico em pacífico, desenriçada, ela é "convexa", .

Reconverte: o encouraçamento côncavo na carne de antes, convexa, propícia,

Ora, com a reescrita João Cabral simplesmente abandona o conceito de concavidade na adjetivação da ouriça eriçada e o reutiliza ao inverter a qualificação da ouriça quando, desriçada, esta mostra sua carne:

Reconverte: o metal armado e metálico na carne de antes, côncava e propícia, 456

Há aqui um exemplo de forte assimetria: deixa de haver a oposição entre a concavidade da ouriça quando se arriça e sua convexidade quando se desenriça, e a "carne" da ouriça sem espinhos de côncava passa a ser, contrariamente, convexa. Trata-se, possivelmente, da representação de duas posições diferentes da ouriça, quando pacífica. Nesse estado, ela ou deixa exposta a carne de seu abdome, ou esconde os espinhos de seu dorso. Na primeira atitude, ela é representada pela oposição entre seu dorso espinhento - que é côncavo - e seu abdome sem espinhos, que é convexo. Na segunda, é representada a partir da oposição de seu dorso com e sem espinhos, em ambos os casos, côncavo.

\footnotetext{
${ }^{456}$ No texto publicado, há, nos dois versos, uma inversão de termos e o acréscimo de parênteses: "Reconverte: o metal hermético e armado/na carne de antes (côncava e propícia)," (Obra completa, op. cit., p. 346).
} 


\section{4. As notas metalinguísticas}

Encontramos nos manuscritos de $A$ educação pela pedra anotações de cunho metalinguístico, feitas por Cabral, relacionadas com seu próprio trabalho de escrita. Faremos referências a várias delas, analisando-as com relação às reformulações do texto. A grande maioria das notas têm a forma de auto-injunção (12), e a outra parte é descritiva (4). A totalidade é, de forma diversa, modalizada factualmente, epistemicamente e axiologicamente, como veremos.

Se nos firmamos na teoria de Bernard Pottier, a injunção é, adaptando seu texto para o singular, uma "modalité d'énonciation liée à la catégorie de la personne" ${ }^{\prime 47}$. A modalidade da injunção, continua o autor, é sobretudo a factual, que se define como o "ensemble des attitudes orientées vers l'agir: le dire et le faire" ${ }^{458}$. Essa orientação em direção ao agir tem graus de engajamento diretamente ligados às marcas lexemáticas da modalidade factual: como "vouloir" (querer), a orientação tem um alvo prospectivo aberto, como "pouvoir" (poder), tanto o agir quanto o não-agir são possíveis, e como “devoir” (dever), afirma Bernard Pottier, "il est difficile d'échapper à l'agir"459.

Pode-se portanto afirmar que a auto-injunção (que, em Cabral, é expressa quase sempre pela forma verbal infinitiva) guarda uma intenção de dizer ou fazer algo, podendo tal intenção ser realizada ou não, e por motivos diversos. A possibilidade da realização está

457 POTTIER, Bernard, Sémantique générale, op. cit. p. 205.

458 Idem, ibidem p. 215.

459 Idem, ibidem, pp. 215 - 216. 
conectada, muitas vezes, com a modalidade epistêmica que se liga à modalidade factual, quer dizer, está ligada com a certeza ou a dúvida do scriptor com respeito ao bem fundado de sua intenção. Além disso, a auto-injunção pode estar modalizada axiologicamente, ainda que o juízo de valor aí presente possa ser relativizado pela dúvida. É o caso da seguinte nota, apensada ao fólio que contém o prototexto do poema "Duas das festas da morte":

No caixão, meio caixão meio pedestal, o morto mais se inaugura do que morre; e duplamente $/: /<,>$ ora sua própria estátua ora $/ \mathrm{o} /<$ seu $>$ próprio vivo, em dia de posse.

melhor que dia de posse dizer para discurso 460

Ora, ainda que o autor considere mais adequada a expressão "para discurso" do que "dia de posse", conforme se lê na nota, a verdade é que a reformulação não foi efetuada, o que prova que o autor não havia total certeza de seu juízo de valor.

Em outros casos, porém, a auto-injunção é seguida, embora não na mesma campanha de reescrita, mas posteriormente - sem que tenham sido deixados traços da reformulação. É o que podemos observar comparando o prototexto de "Bifucardos de 'Habitar o tempo'" - originalmente intitulado "Habitar o tempo na caatinga" com o texto publicado, atentando-se para a nota metalinguística escrita pelo autor (ver anexo 5):

${ }^{460}$ Pasta Pi. A educação pela pedra 1, $\mathrm{f}^{\mathrm{o}} 71$. 
isola

Desertos voluntários em que se desfaz

\author{
quer \\ quem quis viver o tempo habitadamente; \\ passivos diante \\ desertos viciosos à vista da Caatinga, \\ não \\ deserto involuntário mas com dentes. \\ involuntário porém com dentes \\ mas contrastivamente \\ mas agressivamente \\ mas rebeldemente \\ mas não passivamente
}

Desertos voluntários aonde desertam

Nota: a passivos (ou a que eu escolher) deve ficar em correspondência com o fim do último verso. ${ }^{461}$

A auto-injunção exprime uma intenção de coerência semântica, na medida em que aquilo que é determinado é a correspondência - por meio da contrariedade - entre duas expressões capitais no texto, pois qualificam os dois tipos de desertos objetivados. Os vários paradigmas enumerados logo abaixo do texto datilografado indicam já uma tentativa de produzir essa correspondência, mas ela é deixada em suspenso. Lendo-se o texto definitivo, vê-se que o autor resolveu o problema pondo em relação "viciosamente" e "reage a dentes":

Desertos onde ir viver para habitar-se, mas que logo surgem como viciosamente a quem foi ir ao da Caatinga nordestina: que não se quer deserto, reage a dentes. ${ }^{462}$

461 Pasta Pi. A educação pela pedra 1, fólio 48.

462 Obra completa, op. cit., p. 355. 
O curioso é que o autor retorna de certa forma à versão do datiloscrito. Neste, os paradigmas em correspondência, por contrariedade, eram "viciosos" e "com dentes'. No texto publicado, o autor retém os paradigmas, operando certas variações: o adjetivo "viciosos' torna-se advérbio ("viciosamente"), sendo deslocado um verso acima, e há o acréscimo de "reage" ao sintagma "com dentes".

Passemos agora às notas metalinguísticas escritas no fólio do manuscrito do poema "A cana de açúcar de hoje", dos quais uma já citamos: 


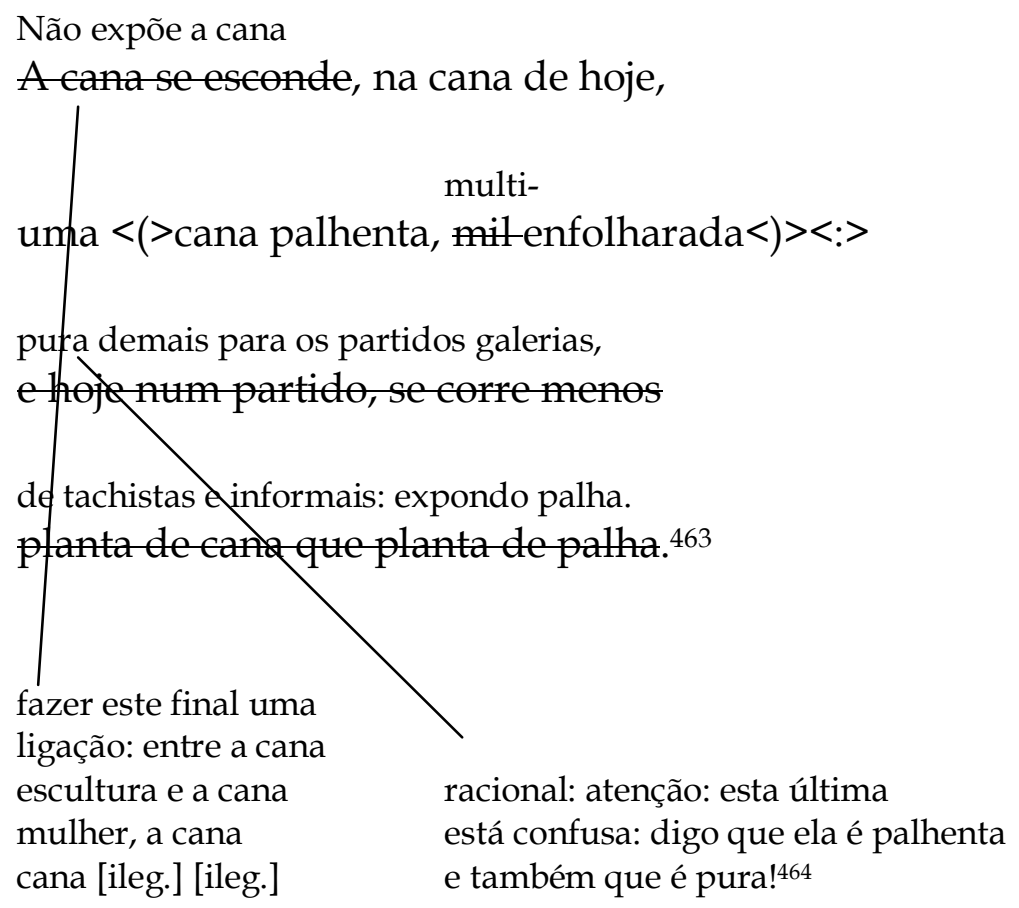

A primeira auto-injunção, à esquerda, exprime uma intenção de reformulação do final da primeira unidade do poema, no sentido de produzir um encadeamento das diversas representações da cana (escultura, mulher, planta) presentes no texto. A reformulação é efetuada, como se pode ver pelos sintagmas "partidos galerias" 465 , e da adjetivação 'pura", (que representaria, provavelmente, a qualidade feminina da cana). A segunda auto-injunção refere justamente a reformulação feita, exprimindo um auto-alerta do autor com respeito à contradição que produziu ao adjetivar a cana, a um tempo, como "pura" e "palhenta", e, logo, contém a intenção de rejeitar a mudança efetuada. Como o texto definitivo retoma praticamente o prototexto,

\footnotetext{
${ }^{463}$ Confira-se a versão definitiva: "A cana se esconde, na cana de agora,/que dá mais palha e evita despalhá-la;/e agora se corre menos, nos partidos,/plantas-de-cana do que plantas-de-palha" (Obra completa, op. cit., p. 354).

${ }^{464}$ Pasta Pi. A educação pela pedra 1, fo 1 .

465 Um partido é uma "grande extensão de terreno plantado de cana-de-açúcar' (Dicionário Houaiss)
} 
infere-se que a falha na reformulação tenha sido suficiente para que João Cabral tenha desistido de sua intenção de reformular o final da unidade.

O próximo exemplo também dá mostras de auto-injunções de controle que evitam também uma contradição, e de outra intenção não realizada. Trata-se do manuscrito da segunda unidade do poema "Psicanálise do açúcar": 
Só os banguês que-ainda purgam ainda

o açúcar bruto com barro,

eøm barro o açúcar brute, de mistura;

ela desde a

a usina não o purga $<$,> desde a escola

educa e

e não depois de adulto, ela $\Theta$ apura:

com vácuos e turbinas, clarificadores,

o disciplina: com vácuos e turbinas

com mãos higiênicas, mãos de indústria,

eonfia- $\theta$ a mães industriárias, puras,

a usina o leva a sublimar em

para que o açúcar sublime ne cristal

o pardo do xarope e da origem turva.

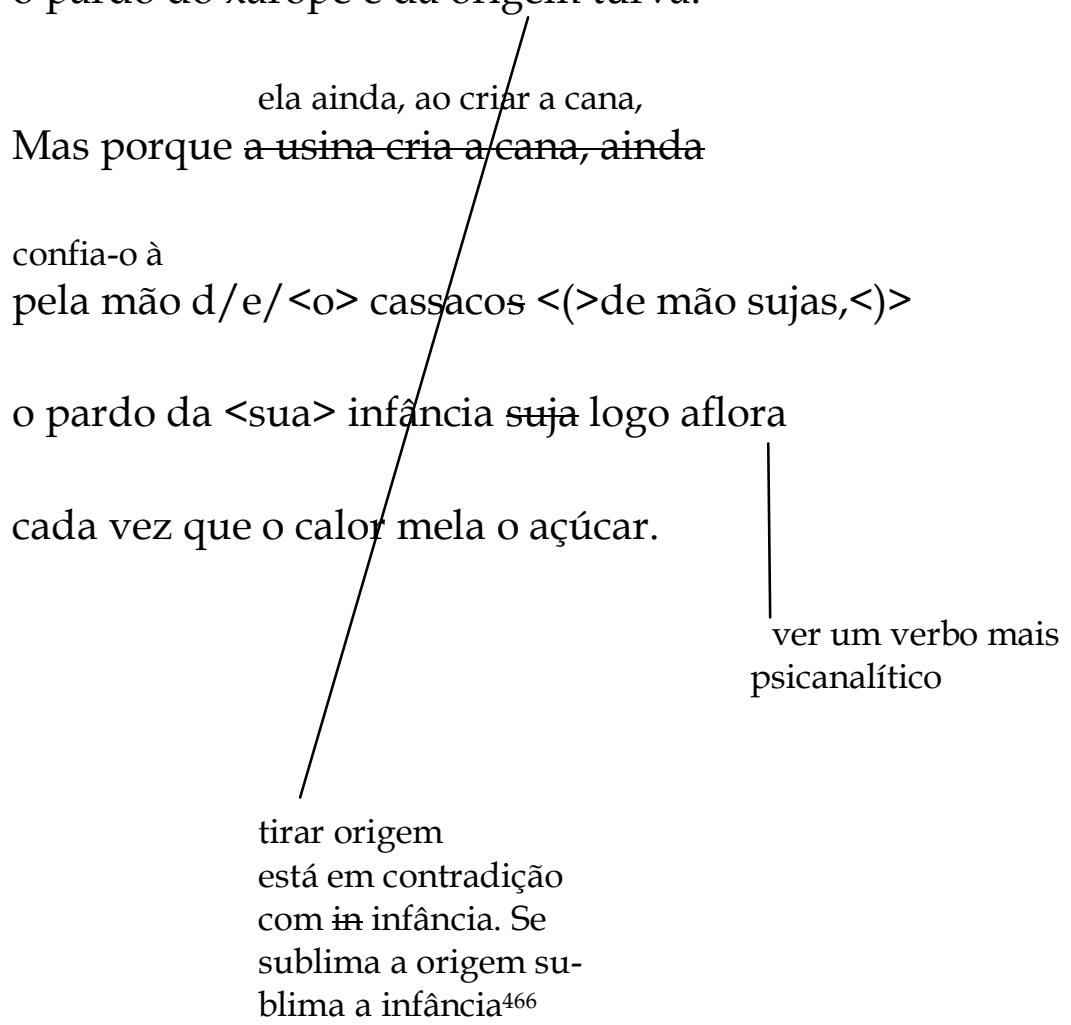

466 Pasta Pi. A educação pela pedra 1., fólio 26. 
A "contradição" (não seria uma redundância?), provinda do uso simultâneo da imagem da sublimação da origem e da sublimação da infância, é resolvida pela substituição do verso "o pardo do xarope e da origem turva" pelo verso "o pardo do xarope: não o purga, cura", na versão definitiva. Mas a auto-injunção que determinava a substituição de "aflora" por um verbo "mais psicanalítico" vai restar letra morta. Compreende-se o propósito do autor: busca-se com a inclusão de mais um conceito psicanalítico reforçar a coerência semântica do poema, no qual vários termos da psicanálise (conforme o desígnio mesmo do título) já tinham sido utilizados ("recalcá-lo", "crise", "ego", "censura"). Por que o não cumprimento do propósito? Não teria sido difícil para Cabral encontrar um sinônimo psicanalítico de “aflora”. É muito comum, nos textos técnicos de psicanálise, por exemplo, a expressão "retorno do recalcado", e, assim, "retorna" teria sido uma solução fácil para a substituição de "aflora". Não tendo sido a dificuldade da solução a causa da desistência, e havendo bons motivos (a coerência semântica) para a reformulação do termo, fica sem resposta a pergunta.

Os exemplos de intenções não realizadas, ao lado de um controle intencionalmente claro, mostra o quanto em Cabral vão juntas uma conduta arquitetônica - de vigilância lúcida da efetuação de projeções de significação - e uma conduta processual, a qual o projeto de significação sofre as coerções do trabalho sobre o material linguístico, transformando-se, ou não se concretizando durante o processo de escrita.

Outras notas metalinguísticas guardam uma modalização epistêmica fortemente dubitativa, o que mostra o quão a intenção do que deve, ou pode ser dito, não é, de forma alguma, clara, pefeitamente lúcida. Por exemplo, a anotação que acompanha o manuscrito da 
segunda unidade do poema "Habitar o tempo", do qual transcrevemos o início (ver anexo 6):

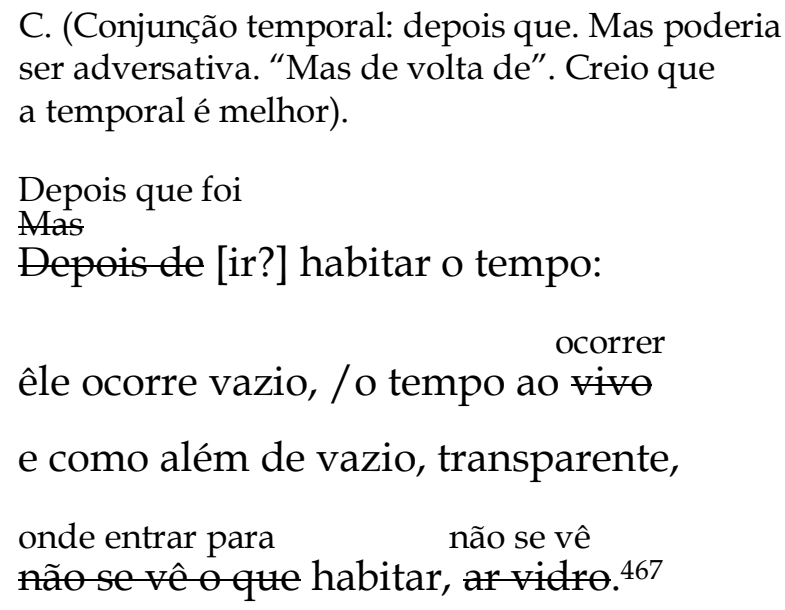

Trataremos aqui somente das reformulações que incidem sobre o primeiro verso e da nota legível no alto do manuscrito. Temos, portanto, a seguinte série de substuições, considerando a versão publicada:

depois de ir $\rightarrow$ mas de volta de $\rightarrow$ depois que foi $\rightarrow$ e de volta de ir

Três foram as relações estabelecidas pelo autor, dependendo da conjunção utilizada, entre as duas partes do poema, que correspondem a duas experiências de "habitar o tempo" (uma no presente (na "agulha do instante") e, outra, no passado, ("matando"o tempo). Na primeira relação entre as partes, estabelecida através da conjunção “depois", a experiência do tempo presente e do tempo passado estão em um mesmo continuum temporal, havendo sucessão de uma à outra. $\mathrm{Na}$ segunda relação, feita com a conjunção "mas", as duas partes, ou duas experiências temporais, se opõe, havendo clara primazia da segunda sobre a primeira. Finalmente, com a conjunção "e", a relação entre as

467 Pasta Pi. A educação pela pedra 1, fo 36. 
duas partes é paratática, já que a segunda é justaposta à primeira tornando-se ambas autônomas.

As diversas reformulações ensaiadas pelo scriptor da primeira linha deixa explícito o quão hesitante é a decisão entre as duas primeiras estruturas, a temporal e a adversativa. Na primeira versão o autor escolhe a temporal. Ele depois a rasura e a reformula por uma conjunção adversativa. Esta é de novo reformulada e o autor volta a escolher a temporal. O grau de irresolução pode ser medido pela modalização do comentário, que localiza a solução do problema da associação (seja por conjunção temporal, seja por conjunção adversativa) no campo do puro possível ("mas poderia ser...") ao mesmo tempo que exprime uma forte dúvida quanto à forma a ser adotada ("Creio que...):

C. (Conjunção temporal: depois de. Mas poderia ser adversativa. "Mas de volta de". Creio que a temporal é melhor). (O grifo é nosso)

A dúvida expressa é de tal maneira forte que o autor acabará por abandonar tanto a conjunção temporal quanto a adversativa em favor da copulativa "e". Vê-se por esse exemplo o quanto uma intenção de origem pode ser hesitante e se transformar por diversas vezes durante o trabalho de reformulação.

Um quarto prototexto dará a ver um exemplo de auto-injunção que exprime uma confunsão do autor com respeito à textualização de seu poema. Trata-se do comentário presente no manuscrito da $2^{\mathrm{a}}$ unidade de "Fazer o seco, fazer o úmido": 
uma província entre sêcas,

A gente de um Pernambuco antípoda

leva as gotas de chuva recortadas

que conta a chuva, favas não contadas,

se acolhe a uma música tão líquida,

que melhor se executaria com água.

Talvez porque

JR Certoas gotas dessa música chovida

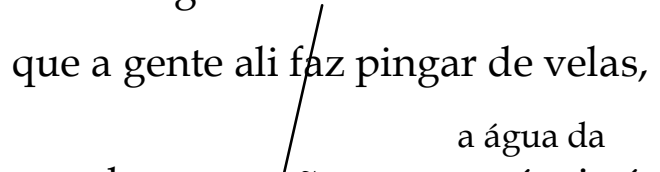

umedecem, sehão com a própria água,

com a compahhia da água, langorosa.

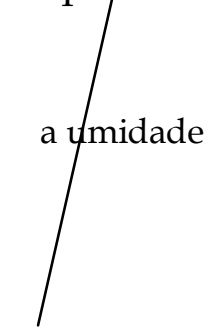

Para esta $2^{\mathrm{a}}$ parte ficar JR é preciso tirar gotas e chovida desse $5^{\circ}$ verso 468

Não comentaremos aqui a mudança radical da modalidade espistêmica do quinto verso, já referida, da certeza para a dúvida, que transforma completamente a relação entre as duas semi-partes da unidade. Ela acontece também na reformulação do quinto verso da primeira unidade, à qual também já nos referimos. Digamos apenas que essa mudança modal, que diminui o grau de adesão do EU com respeito a seu propósito ${ }^{469}$, relativiza a veracidade da representação que

468 Pasta Pi. A educação pela pedra 1, fólio 52.

469 Conforme a definição da modalidade espistêmica proposta por Bernard Pottier: “Cette aire de modalité [l'épistémique] exprime le degré d'adhésion du JE, vis-à-vis de son propos"(Sémantique générale, op. cit., p. 210). 
é feita, no poema, da música da gente do Sertão, gente que, apesar de viver em um lugar seco, faria uma música umedecida, quase líquida. ${ }^{470}$

A auto-injunção do autor ("é preciso"), diz respeito a uma transformação necessária para que as duas semi-partes da unidade tenham uma associação por "JR" (justaposição com repetição de elementos das 2 linhas anteriores). Segundo a nota meta, para que haja a estrutura "JR", seria preciso substituir duas palavras do verso, "gotas" e "chovida". Essa substituição não é feita no manuscrito. Mas se se compara o texto do manuscrito com o texto publicado, verifica-se uma certa diferença:

Texto manuscrito:

/Certo/<Talvez porque > as gotas dessa música chovida

Texto publicado:

Talvez as gotas úmidas dessa música ${ }^{471}$

Ora, apesar dessa diferença, observa-se que o próposito contido na auto-injunção não foi cumprido. A palavra "gotas" permanece ainda, e a palavra 'chovida" e substituída por um sinônimo "úmidas", mas que não mais serve para qualificar "música" e, sim, "gotas", configurando-se uma clara tautologia no texto definitivo ("gotas úmidas"). O mais curioso é que a estrutura "JR", à qual se queria chegar, já existia na primeira versão. Com efeito, se "JR" significa “justaposição com repetição de elementos das 2 linhas anteriores", então a segunda semi-parte era exatamente assim justaposta, já que havia a repetição de "música tão líquida" em "música chovida". Outra

${ }^{470} \mathrm{E}$, contrariamente, na primeira unidade, a gente do litoral, apesar de viver em um lugar úmido, faria uma música de "metal sem sede", que "risca uma faísca".

471 Obra completa, op. cit., p. 340. 
não é a conclusão: a auto-injunção exprime uma intenção confusa, já que ela não corresponde às definições dadas pelo autor dos tipos de justaposições e associações que estabelece.

Por fim, e com relação, agora, às notas puramente descritivas, daremos apenas um exemplo devido ao esclarecimento feito quanto à diferença do poema "Para a feira do livro" (ver anexo 8) com relação aos outros textos contidos no livro A educação pela pedra. Basta, neste caso, citar o comentário:

Este é o único poema que não tem nenhuma palavra comum entre às duas unidades ${ }^{472}$

E, de fato, comparando o manuscrito com o texto publicado, as duas unidades do poema permanecem sem nenhuma palavra em comum. Isso significa que se trata de um texto cujas partes têm uma relação rigorosamente paratática, sem qualquer ligação, de tal maneira que configuram poemas completamente independentes um do outro. Em um livro onde tudo deveria ser dividido por dois, a existência de um poema com características únicas bem que configura uma anomalia.

472 Pasta Pi. A educação pela pedra 1, fólio 3. 


\section{5. O manuscrito do poema "Catar feijão"}

Gostaríamos, agora, de fazer uma análise mais detalhada de um só prototexto, o do poema "Catar feijão", já que se trata de um poema que tematiza explicitamente a criação literária, o que nos propiciará a oportunidade de comparar a representação, aí feita, do escrever com a própria atividade de escrita legível nos traços manuscritos. A seguir, transcrevemos o documento, cuja cópia fotográfica pode ser consultada no anexo 4. 
Catando

SOBRE CATAR FEIJÃO

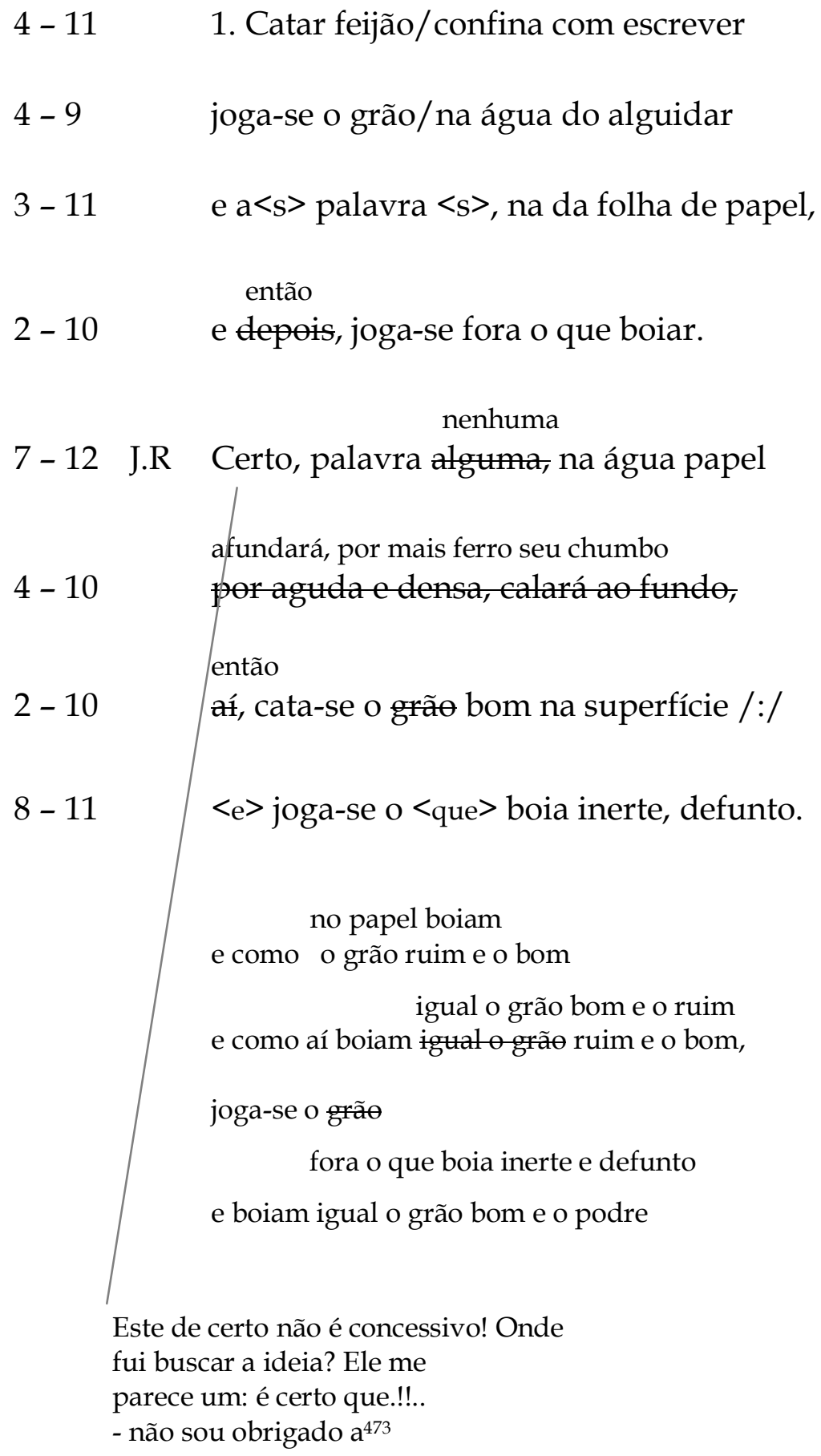

Este de certo não é concessivo! Onde fui buscar a ideia? Ele me parece um: é certo que.!!.. - não sou obrigado $\mathrm{a}^{473}$

473 Pasta Pi. A educação pela pedra 1, fólio 59. 
C. (conj. ilativa)

Ora, nesse catar feijão há um risco,

8- 11

2. Eerte, nessa forma de catar feijão

o de que nos grãos entre

6-9 resta um riseo: de neles, por entre,

um qualquer ou

4- 9 meter-se um grão, indigesto de pedra

4- 10 ou inquebrável, <grão> de quebrar um dente.

quando se cata palavras:

3-10 J Certo não, eatando palavra: a pedra

uma pedra dá à

7 - 12 mete entre a frase/um grão efetivo:

$7-11$ brida a leitura fluviante, flutual,

5 - 10 açula a atenção, isca-a com o risco. ${ }^{474}$

474 Pasta Pi. A educação pela pedra 1, fólio 60. 
Os números à esquerda foram escritos por João Cabral de Melo Neto, e servem ao controle da métrica dos versos, cuja contagem se efetua, como já observamos antes, depois das reformulações. Como se vê, Cabral, ao contar as sílabas, considera somente a cesura mais forte, dividindo, portanto, os versos de A educação pela pedra, de forma irregular, em dois "hemistíquios".

Como bem observou Benedito Nunes, a estrutura do poema “Catar feijão", conforme o texto publicado, é determinada pelos nexos lógicos estabelecidos através de conjunções e advérbios. Citemos o crítico:

Podemos constatar aí a função estruturante dos nexos lógicos, tanto conjunções como advérbios (certo, pois, ora, certo não) numa forma mista, proso-poética. Valorizando-se as conexões lógicas da linguagem, os moldes que ficam à mostra, na construção do poema, são mais expositivos do que descritivos. ${ }^{475}$

Antes de determinar as diferenças dessa estrutura lógica do texto definitivo com a estrutura do prototexto, apresentemos sucintamente o conteúdo e a tessitura argumentativa do poema, tal como publicado. Trata-se aí de expor as semelhanças e diferenças que há entre o ato de “catar feijão" e o ato de escrever. A duas estrofes ou partes do poema são ligados por um continuum lógico, através da conjunção “ora”, de valor ilativo, pois introduz uma conclusão que revela a diferença fundamental, calcada nas similaridades e dessemelhanças entre um ato (o de catar feijão) e outro (o de escrever), anteriormente expostas no poema ${ }^{476}$. Cada uma das metades do poema pode, por sua vez, ser

475 NUNES, Benedito, João Cabral de Melo Neto, op. cit., p. 135.

476 O valor conclusivo de "ora" é assinalado pelo próprio poeta no manuscrito. ("conj. ilativa"). O uso dessa forma com tal valor é atestado por Maria Helena de Moura Neves em sua Gramática dos usos do português, p. 560. "Ora", segundo a autora, marca uma "sequência do texto, introduz uma conclusão". E dá o seguinte exemplo:"Mas é que me sinto assim, com a impressão permanente de estar sendo 'vigiada'. Ora, nesta 
dividida em duas semi-partes, com quatro versos. Citemos a primeira semi-parte da primeira parte:

Catar feijão se limita com escrever: jogam-se os grãos na água do alguidar e as palavras na da folha de papel; e depois, joga-se fora o que boiar. ${ }^{477}$

Nela é estabelecida uma analogia entre catar feijão e escrever: jogam-se os grãos na água do alguidar, assim como, na escrita, são jogadas as palavras no papel; depois, também em ambos os casos, lança-se fora o que boia. Se nesta primeira semi-parte expõe-se uma semelhança entre a cata e a escrita, na segunda, que se justapõe à primeira apenas repetindo alguns de seus termos, ao contrário, são expostas diferenças:

Certo, toda palavra boiará no papel, água congelada, por chumbo seu verbo: pois para catar esse feijão, soprar nele, e jogar fora o leve e oco, palha e eco. ${ }^{478}$

tensão não consigo respirar, não sei mais viver. Asfixio.". Um dos equívocos da análise que Valéria Paz de Almeida (A retórica da pedra. Análise da argumentação no discurso poético de João Cabral de Melo Neto. Mestrado: Universidade de São Paulo, 2001) faz do tecido argumentativo do poema é a interpretação de "ora" como opositivo. Conforme Valéria Almeida, na segunda parte do poema, "o enunciador resolve redefinir a tese e, por meio de um mas argumentativo, posto entre as duas estrofes do poema e manifestado pelo operador 'ora', abandona, mas não nega, a tese inicial, iniciando então um novo processo de comparação, dessa vez por contraste." (p. 83). Mas como ilativa, 'ora' não abandona o que foi afirmado, ela, ao contrário, dá prosseguimento à argumentação, introduzindo uma consequência calcada no que foi anteriormente exposto.

477 Obra completa, op. cit., p. 347.

478 Vemos um outro equívoco de Valéria Paz de Almeida em seu comentário sobre essa passagem. Citemos a autora: "Pois (verso 7), no poema, opera uma relação de conclusão, portanto argumentativa, na qual uma das premissas é consenso em determinada cultura. Sabe-se, de acordo com a cultura em que se inscreve essa formação discursiva, qual é o procedimento para catar feijão: os grãos são colocados na água e os resíduos da palha ou outro tipo de sujeira boiam e são retirados, separados dos grãos de feijão. Ora, se o processo de escritura é semelhante, 'para catar esse feijão', que é a palavra, deve-se pois (portanto) fazer algo similar ao que se faz na cata do feijão, ou seja, deve-se 'soprar nele e jogar fora o leve e oco, palha e eco', o inútil, o que não se aproveita." (pp. 81-82). Mas, pura e simplesmente, o que é asserido 
A segunda semi-parte, por meio de um advérbio assertivo ("Certo", ou seja, "é certo que"), começa por afirmar categoricamente uma primeira diferença entre ambos os atos: na cata, o grão do feijão bom afunda e o podre boia, enquanto que, na escrita, palavra nenhuma boia sobre o papel, evidentemente. Essa asserção leva à conclusão de uma distinção no procedimento de escrita com relação à cata: se toda palavra "boia" sobre a folha de papel, é preciso, portanto, diferentemente da cata, onde se colhe o grão bom no fundo, "soprar" as palavras na superfície mesma da página, jogando fora o que lhe é excessivo.

Dessas últimas diferenças, o autor tira uma consequência, exposta nas duas estrofes finais, que aponta para outra dessemelhança, agora essencial, entre os dois procedimentos. Tal conclusão é introduzida pela conjunção "ora", e a primeria quadra descreve uma especifidade da cata, qual seja, o risco indesejado de, entre os grãos bons, encontrar-se um grão duro:

Ora, nesse catar feijão entra um risco: o de que entre os grãos pesados entre um grão qualquer, pedra ou indigesto, um grão imastigável, de quebrar dente.

Com essa especificidade da cata, a do risco de que um grão ruim afunde, contrastará fortemente, a ponto de ser seu contrário, uma especificidade própria da escrita, descrita nos últimos quatro versos do poema:

Certo não, quando ao catar palavras:

a pedra dá à frase seu grão mais vivo:

obstrui a leitura fluviante, flutual,

açula a atenção, isca-a com o risco.

na proposição logo antes do "pois" não é a "semelhança" entre a cata e a escrita, mas o contrário, a sua diferença: sopram-se as palavras, porque elas não afundam quando lançadas na superfície do papel, diferentemente do feijão, cujos grãos bons afundam. 
O primeiro verso da quadra acima poderia ser glosado assim: "certamente que não há o risco do grão duro na escrita (como há na cata do feijão)", quer dizer, "certo não" tem valor assertivo. A ausência desse risco está estreitamente ligada ao fato de nenhuma palavra afundar no papel, e que o soprar as palavras não lança fora as que tem textura pétrea, muito ao contrário, são elas que permanecem, e somente voam sua "palha". Ou seja, por meio de uma negação que expressa um certeza, a quadra completa o último e fundamental contraste entre a cata e a escrita: na cata há o medo do risco do grão duro, na escrita, diferentemente, há, como afirmou Antonio Carlos Secchin, em sua leitura do poema, o "desejo do risco" 479 :

$\mathrm{Na}$ versão definitiva do poema temos, portanto, a seguinte estrutura argumentativa:

$1^{\text {a }}$ semi-parte: A cata é similar à escrita: jogam-se e catam-se grãos e palavras na água como no papel.

$2^{\mathrm{a}}$ semi-parte: É certo que a escrita difere num ponto da cata: nela todas as palavras ficam na superfície. Na escrita, portanto, deve-se não catar no fundo a palavra, como se faz na cata do feijão, mas soprá-la na superfície

$3^{\mathrm{a}}$ semi-parte: Ora, na cata há um risco, o grão duro que pode afundar e se confundir entre os grãos bons.

$4^{\mathrm{a}}$ semi-parte: Certamente não há tal risco na escrita, pois como todas as palavras ficam na superfície, e são por isso sopradas, desejamse justamente as mais duras, pétreas.

Quer dizer, há um continuun argumentativo que aprofunda a diferença entre o ato de catar feijão e o de escrever, os quais, no entanto, 479 SECCHIN, Antonio Carlos, João Cabral: a poesia do menos, op. cit., p. 235. 
tinham sido aproximados na primeira metade do poema. O poema é pois assertivo e hipotático.

Ora, veremos pela leitura do manuscrito que tal estrutura lógica, bem longe de ser concebida a priori e lucidamente, é, ao contrário, fruto de um acidente no percurso da escrita.

Na primeira semi-parte não há diferenças importantes entre a versão manuscrita e a publicada: em ambas afirma-se a mesma similaridade entre a cata do feijão e a escrita do poema. $\mathrm{O}$ mesmo não acontece com a segunda semi-parte. No manuscrito lê-se:

Certo, palavra alguma, na água papel por aguda e densa, calará ao fundo, / aí/<então>, cata-se o grão bom na superfície: joga-se o que boia inerte, defunto. 480

Aqui, quer-se o advérbio "certo" com valor concessivo, não assertivo, e a conexão entre os enunciados, feita tanto por "aí", "então" ou " $\mathrm{e}$ ", guarda um valor temporal, mais que lógico, podendo a estrofe ser parafraseada asssim: "Dado que toda palavra boiará no papel, nessa situação cata-se a boa e joga-se fora a ruim, na superfície mesma".

As duas semi-partes seguintes que formam a segunda metade do poema também tinham, na versão manuscrita, um valor concessivo, afirmativa a primeria, negativa a segunda. Vejamos a primeira:

Certo, nessa forma de catar feijão resta um risco: de neles, por entre, meter-se um grão, indigesto de pedra, ou inquebrável, de quebrar um dente.

\footnotetext{
${ }^{480} \mathrm{O}$ dois últimos versos serão reformulados logo abaixo do datiloscrito, da seguinte forma:

e como no papel boiam o grão ruim e o bom

<e como aí boiam igual o grão bom e o ruim>

joga-se fora o que boia inerte e defunto.
} 
Assim começada, com outro "certo" de valor concessivo, a relação entre esta metade com a primeira é inteiramente paratática, diferentemente da versão publicada, onde, começada por "ora", a segunda metade era, hipotaticamente, uma consequência da primeira. A estruturação por justaposição continuava, no prototexto, com o uso de "certo", também com valor concessivo, mas sob a modalidade negativa, na última semi-parte do poema:

Certo não, catando palavras: a pedra mete entre a frase um grão efetivo: brida a leitura fluviante, flutual, açula a atenção, isca-a com o risco.

Pode-se afirmar, portanto, que a versão datilografada tinha uma estrutura concessivo-paratática, com traços perfeitamente descritivos, enquanto que na versão final vingou uma estrutura assertivo-hipotática completamente expositiva. O mais interessante, porém, é a motivação dessa mudança. Ela ocorre devido a um erro de... cálculo. Esse erro está expresso explicitamente no comentário feito pelo autor, na parte de baixo do fólio:

Esse de certo não é concessivo. Onde fui buscar a ideia? Ele me parece um: é certo que!!..

- não sou obrigado a

O comentário impressiona. Um engano, devido a uma ambiguidade do termo "certo", levara o autor a toda uma construção não cabível. Mas muito mais que isso. Será esse engano que levará o scriptor ao seu texto final. De fato, percebendo que a palavra que escolhera não tem o valor semântico que intencionara, ele abandona ("não sou obrigado a") a construção paratática, que projetara, calcada no "certo" de valor concessivo, e a refaz a partir de um "certo" com valor assertivo, escrevendo um poema expositivo e com estrutura 
hipotática. Assim, a nova estrutura surge como que por acaso, à revelia da intenção original do autor.

Já se disse sobre o poema "Catar feijão" que contém "um ponto de vista analítico que habilmente define $\mathrm{o}$ ato de escrever $\mathrm{e}$ simultaneamente o concretiza", que, nele, "há uma perfeita junção entre teoria e prática" ${ }^{481}$. Acreditamos que essa tese somente pode ser comprovada com a análise dos manuscritos, onde se encontram os traços das operações de produção de sentido, logo, da prática de escrita. E os documentos genéticos do poema mostram que ela é só parcialmente verdadeira. Conforme diz o texto de "Catar feijão", escrever seria um processo de depuração, conforme a ideia da "poesia do menos", que retira da linguagem o que é "palha e eco", preservando somente o "grão duro", a palavra-pedra que "açule" a atenção do leitor. O crítico Antonio Carlos Secchin, comentando o verso "um grão qualquer, pedra ou indigesto", mostra como isso está presente no texto:

[em tal verso] há um termo paradigmaticamente substantivo que desempenha função (adjunto adnominal) de categoria adjetiva: isomorficamente, o "grão" que atingiu a sintaxe foi o signo "pedra", que já contém em si a noção de obstáculo que seu posicionamento frasal ratificou. ${ }^{482}$

Se observamos a série de reformulações da passagem em questão:

481 SOLANOWSKI, Marly, João Cabral de Melo Neto: uma lição de poética apud MAMEDE, Zila, Civil geometria: bibliografia crítica, analítica e anotada de João Cabral de Melo Neto. 1942 -1982..São Paulo: Nobel/Edusp/Instituto Nacional do Livro, 1987, p. 282.

482 SECCHIN, Antonio Carlos, João Cabral: a poesia do menos, op. cit., p. 235. 
1) meter-se um grão indigesto de pedra

2) um qualquer grão, indigesto ou pedra

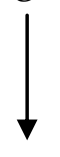

3) um grão qualquer, pedra ou indigesto

vemos que João Cabral somente consegue transformar a palavra "pedra" na pedra do poema processualmente, por meio da operação parafrásica. Num primeiro momento, ele deixa de subordinar "pedra", coordenando-a pela substituição da palavra que lhe antecede, de preposição por conjunção (indesto de pedra $\rightarrow$ indigesto ou pedra). Depois ela a desloca, trazendo-a para perto da pausa, na passagem de (2) para (3), de tal maneira que é nela que se "tropeça" no decorrer da leitura.

Mas o que dizer das reformulações que levaram à mudança da estrutura argumentativa do poema? $\mathrm{O}$ fato delas terem acontecido para corrigir um erro de cálculo não combina bem com esse procedimento tão calculado que é a "depuração", já que depurar significa produzir de equivalências mais precisas em busca de um texto com qualidade sintática e semântica já pré-determinada.

Essa pré-determinação formal não é, portanto, tão rígida assim em Cabral, como seria desejável numa arquitetura projetual. Os acidentes do percurso fazem o autor lançar mão de seu livre-arbítrio. Relembremos a nota metalinguística que acompanha o poema:

Esse de certo não é concessivo. Onde fui buscar a ideia? Ele me parece um: é certo que!!..

- não sou obrigado a 
Quer dizer, o autor "não é obrigado a" insistir na estrutura concessivo-parática, de fato mais "dura" que a concessivo-hipotática, a qual, no entanto, será definitiva. Mais uma vez, aqui, a necessidade do desenho se submete às imprevisibilidades do canteiro, a metáfora da mineralização cede ao conceito mais literal de reformulação processual que engendra novas estruturas durante o percurso criativo, não importa o motivo, inclusive o erro de cálculo. 


\section{Capítulo 3. O dossiê de $A$ escola das facas}

Na terceiro e último capítulo desta parte analisaremos alguns prototextos de poemas do livro A escola das facas. O espírito será o mesmo das análises anteriores, qual seja, descrever as modificações estruturais e locais operadas sobre o texto durante o processo de escrita. Já vimos, por meio das análises anteriores, que a conduta criativa de Cabral não pode ser reduzida a uma pré-determinação intencional de formas e conteúdos seguida de uma realização rigorosa. Ainda que algumas coerções poiéticas permaneçam as mesmas - número de partes, número de versos, métrica - a estrutura semântica do poema pode sofrer transformações mais ou menos profundas no processo compositivo, conforme as reformulações produzam enunciados equivalentes ou assimétricos com relação ao texto de origem. A produção de assimetrias mostra que a teleologia inerente ao processo não se traduz somente por uma progressiva e controlada "mineralização" da linguagem. Esta implica, como "depuração" do excesso semântico, somente a produção de enunciados equivalentes cada vez mais precisos e adequados à representação desejada pelo poeta. Diferentemente, as assimetrias, e quanto mais distorcivas são, implicam o abandono de certas intenções de origem, por motivos diversos, inclusive puramente casuais. Dessa forma, o procedimento cabralino também se caracteriza como processual, e não somente como programático.

A análise de algumas peças do dossiê genético de $A$ escola das facas aprofunda essa visão processual da conduta do poeta. De fato, 
veremos como esse dossiê nos mostra que é somente durante o processo, e não no projeto, que a forma e o conteúdo das representações poéticas de Cabral são fixadas. E, isso, de uma maneira bem mais marcada do que nos dossiês genéticos de Serial e A educação pela pedra.

Os documentos analisados adiante foram retirados de duas pastas depositadas no acervo literário do autor: pasta Pi. Poemas pernambucanos. Original, e pasta Pi. Poemas pernambucanos ${ }^{483}$. A primeira é constituída por 107 fólios não numerados, que contêm a totalidade dos poemas de $A$ escola das facas, com várias reformulações, na versão mais antiga das que há disponíveis. A segunda, com 110 fólios numerados, mais um sem numeração, contém os mesmo textos também reformulados. Esse conjunto de documentos, incluindo os textos tal como publicados servirão de base para nossas análises.

Começaremos por fazer menção ao poema "O que se diz ao editor a próposito de poemas", intitulado originalmente "Bilhete a José Olympio e Daniel (para servir de prefácio)". Este poema de caráter "metalinguístico" apresenta a visão cabralina do fazer mais condizente, acreditamos, com sua própria atividade criativa, visão que figura o poema como algo essencialmente instável, sujeito a diversas operações de reformulação (elencadas pelo autor) enquanto não é "mumificado" em livro. O que é dito no poema sobre a criação literária nos servirá de orientação para a análise de dois outros documentos. Primeiro, os protextos de "Prosas da maré na Jaqueira", que sofreu diversas mudanças de título e estrutura no decorrer de sua composição. Segundo, o manuscrito do poema "Descoberta de literatura", que nos mostra o procedimento cabralino não é somente o do "menos", o do

483 "Poemas pernambucanos" é o primeiro título de $A$ escola das facas. A mudança ocorreu por sugestão de Antonio Candido como relata o próprio crítico em VASCONCELLOS, Selma (org.), João Cabral de Melo Neto: Retrato falado do poeta, op. cit., p. 157. 
corte, porém também o do "mais", o do enxerto, que amplia o poema, introduzindo modificações semânticas consideráveis. O prototexto da $3^{\mathrm{a}}$ parte do poema "O mercado a que os rios", também pertencente ao dossiê, já foi brevemente analisado no segundo capítulo da primeira parte, e nos deu o exemplo de como o começo da escrita de um texto por Cabral pode ser hesitante, de tal forma que o sentido é descoberto e fixado somente no decorrer do processo de composição. 


\title{
3. 1. A operação do poema instável
}

\author{
BILHETE A JOSÉ OLYMPIO E DANIEL \\ (PARA SERVIR DE PREFÁCIO)
}

Há mais um livro (fio que último)

de um incurável pernambucano;

programam ainda

se querem ainda publicá-lo,

digam-me, que com pouco o embalsamo.

E preciso logo embalsamá-lo:

enquanto ele me conviva, vivo,

está sujeito a cortes, enxertos:

amputado do

terminará perdendo seu fígado,

outro

ou terminará ganhando um pâncreas;

o

e se seu pulmão não pode outro estilo,

esta

essa-dicção de tosse e de gagueira,

quero amputar-me esse livro-umbigo.)

me exgota [sic], vivo em mim, livro-umbigo.)

Poema nenhum se autonomiza

no primeiro ditar-se, esboçado,

nem no construí-lo, nem no passar-se

a limpo, no datilografá-lo. 
Um poema é o que há de mais instável,

ele se multiplica e divide,

se pratica as quatro operações

em nós e de nós vive

enquanto variávelem nós vive.

Um pøema comø um câncer cresce

mesmo radiografado e descrito:

parar es pés desse existir louco

só mumificando-o, pondo-o em livro.

Um poema é sempre como um câncer:

indivíduo

que química, cobalto, quem pôde

parou os pés desse potro solto?

só o mumificá-lo, pô-lo em livro. ${ }^{484}$

Esse datiloscrito, reformulado com caneta azul, se localiza na pasta intitulada Pi. Poemas pernambucanos. Original, que contém a primeira versão disponível dos poemas do livro A escola das facas, publicado em 1980.

"Bilhete" antes, conforme o primeiro título, o poema torna-se menos circunstancial com o título definitivo, onde se explicita o assunto mesmo do texto ("O que deve se dizer ao editor a propósito de poemas"). Bem entendido, como a leitura dos versos mostrará, o que se deve dizer a propósito do processo de escrever poemas. Trata-se de um poema metapoiético, pois tem como objeto a relação entre sujeito criador e a obra que cria. O pequeno comentário de Antonio Carlos

484 Pasta Pi. Poemas pernambucanos. Original, sem indicação de fólio. 
Secchin, apreende, ainda que um pouco inexatamente, o sentido geral do poema:

O poema-preâmbulo [tece] considerações sobre a poesia em geral, e sobre o embate entre o criador e o objeto que ele cria. João Cabral reitera algumas concepções já estampadas em O engenheiro (1945) e na "Fábula de Anfion" (1947): poesia como força indomável, que só se cristaliza plenamente quando "extinta" no repouso mineral da folha impressa. Assim, "embalsamar" e "mumificar" são as condições para que, livre do poeta, o poema efetivamente nasça. ${ }^{485}$

O início do comentário é correto: o poema trata de fato da conduta criativa do poeta, e, realmente, como vimos no pequeno comentário que fizemos a este mesmo poema no segundo capítulo, algumas metáforas vitalistas de representação do fazer, já usadas em $O$ engenheiro e "Fábula de Anfion", são retomadas. Mas parece-nos que há um evidente contrassenso no comentário do crítico quando interpreta a "mumificação" do poema no livro como seu "nascimento". Sem dúvida, nascimento para o leitor, mas "morte" para o autor, e é esse o sentido que interessa no texto. "Mumificar" o poema, pondo-o em livro, significa, se estar vivo é transformar-se, que, publicado, ele está definitivamente morto, pois não será mais reformulado.

O poema pode ser divido em duas grandes partes.

Na primeira parte, que vai da primeira estrofe até a terceira inclusive, o objeto-tema do poema é o livro - o livro A escola das facas ("/Hál <Eis> mais um livro..."486) - que é tratado a partir de uma metáfora biológica: o livro é um organismo humano vivo.

A metáfora do livro como organismo humano vivo na primeira parte do poema é atestada nas imagens do $6^{\circ}$ verso ("enquanto ele [o livro] me conviva, vivo"), dos $8^{\circ}, 9^{\circ}$ e $10^{\circ}$ versos, onde se lê que o livro

485 SECCHIN, Antonio Carlos, João Cabral de Melo Neto: a poesia do menos, op. cit., p. 274. 486 A reformulação há $\rightarrow$ eis se localiza na segunda campanha de reformulação do texto, pasta Pi. Poemas pernambucanos, fo 1 . 
tem um "fígado", um "pâncreas" e um "pulmão", e $12^{\circ}$ verso ("me exgota [sic], vivo em mim, livro-umbigo").

Na primeira parte do poema, duas são as relações do poeta com o livro que faz:

1) o poeta contém em si o livro, como se pode ler no $6^{\circ}$ verso ("enquanto ele [o livro] me conviva, vivo)"e no $12^{\circ}$ verso ("me esgota, vivo em mim, livro-umbigo"). Nesse sentido, o livro é figurado como organismo parasitário, pois vivendo no poeta e do poeta, causa-lhe dano (lhe "esgota"), devido ao esforço que requer para sua composição indefinida.

2) o poeta opera o livro, como se pode ler nos versos $7^{\circ}$ (“ [o livro] está sujeito a cortes, enxertos"), $8^{\circ}$ ("terminará / perdendo seu/ <amputado do> fígado") e $9^{\circ}$ (terminará ganhando /um/ <outro> pâncreas"). O sentido da operação aqui deve ser precisado. O corte, o enxerto, o transplante e a amputação são operações como que exigidas pelo livroorganismo e não tem como finalidade curar o poeta do parasita, mas, ao contrário, intensificam a convivência entre um e outro. A cura somente seria possível pelo "embalsamento", quer dizer, através da publicação, evitando o esforço de renovadamente transformá-lo.

Na primeira versão, a operação de cura seria a de "amputação" do livro-parasita, retirando-o do espírito do poeta ("quero amputar-me esse livro-umbigo"). Esse verso será, no entanto, substituído por "me esgota, vivo em mim, livro-umbigo" e a operação de amputação fará parte do tratamento dado ao livro enquanto vivo. Observe-se que as quatro operações medicinais acima podem ser relacionadas a três operações básicas de escrita: corte e amputação corresponderiam à supressão, o enxerto ao acréscimo e o transplante à permutação. 
Na segunda grande parte do poema, que corresponde às três últimas estrofes, abandona-se o registro particular da primeira parte onde o livro objetivado é específico, o próprio A escola das facas - e passa-se a um outro registro onde, agora, é o poema em geral que é posto como objeto. Cada uma das estrofes é a descrição dos vários aspectos do poema, enquanto algo que se faz, sempre sob a perspectiva da instabilidade.

$\mathrm{Na} 4^{\mathrm{a}}$ estrofe nega-se a autonomização do poema, independentemente da fase do processo criativo:
Poema nenhum se autonomiza no primeiro ditar-se, esboçado, nem no construí-lo, nem no passar-se a limpo, no datilografá-lo.

Ou seja, o poema estará sujeito a reformulações pouco importando o quão avançado esteja seu processo compositivo. As reformulações a que está sujeito o poema são enumeradas na estrofe seguinte que, por meio de metáforas matemáticas, retoma as operações reformulativas antes figuradas medicinalmente (cortar, enxertar, transplantar):

Um poema é o que há de mais instável, ele se multiplica e divide, se pratica as quatro operações enquanto / variável em nós vive/<em nós e de nós vive>.

Observe-se que a a metáfora matemática não representa aqui o cálculo arquitetônico do poema, porque as operações não são orientadas para um resultado determinado que se quer realizar. Ao contrário, na medida em que o poema "se pratica as quatro operações" enquanto é vivo e variável, a metáfora matemática aponta para um 
cálculo infinito como se o poema fosse um problema sempre se renovando. Essa interpretação se confirma pela noção de instabilidade inerente ao poema explícito no $19^{\circ}$ verso

Um poema é o que há de mais instável

e também explícito na primeira versão do $20^{\circ}$ verso, em termos de variabilidade:

enquanto variável em nós vive.

substituído, na reformulação, por

enquanto em nós e de nós existe.

A substituição acima, além de, possivelmente, evitar a repetição indesejada do conceito de instabilidade, já presente no $19^{\circ}$ verso, reforça entranhamento do poema e seu parasitismo enquanto organismo que depende de outro (o do poeta), o qual molesta.

Na $6^{a}$ estrofe, retoma-se justamente o caráter malsão do livroorganismo, por meio de uma metáfora que o representa como uma doença. O primeiro verso da estrofe, na versão datilografada é:

Um poema como um câncer cresce

Substituído por:

Um poema é sempre<,> como um câncer ${ }^{487}$

${ }^{487}$ A vírgula deste último verso não consta na versão manuscrita. 
A substituição suprime, por um lado, uma certa incoerência já que poderia levar a pensar que um poema, enquanto não publicado, somente se expandiria ("Um poema como um câncer cresce"), o que não é o caso, pois ele também é cortado, nele se enxerta e nele se transplanta. E, por outro lado, reforça a ideia de "incurabilidade" do poema, como se vê na primeira versão do verso, sem a vírgula (“Um poema é sempre como câncer). O acréscimo da vírgula ("Um poema é sempre, como um câncer"), ressalta a noção de inacabamento do poema que se faz, estudada por nós na parte anterior, e que, como vemos aqui, à obra em processo.

À imagem do poema como um câncer, acrescenta-se outra, no penúltimo verso da última estrofe, e que enfatiza seu caráter incontrolável. Na primeira versão temos:

[Como] parar os pés desse existir louco

E na versão definitiva:

[Quem] parou os pés desse potro solto

Assim, as noções de descontrole e de imprevisibilidade estão presentes em todo o texto, relacionadas à criação literária. O poema é instável, variável, incurável (como doença), incontrolável (como um potro solto ou um existir louco). "Potro solto" é uma metáfora quase idêntica à já usada em "Fábula de Anfion", onde a "flauta", metáfora da criação, é um "cavalo/solto, que é louco". Refiram-se também os versos de "Psicologia da composição": 
O poema, com seus cavalos,

quer explodir

teu tempo claro 488

Todas essas imagens, que comparam o poema enquanto é feito com um animal incontroláve, ressaltam a noção de instabilidade própria ao fazer. A tauromaquia, da qual já tratamos na parte anterior, aqui seria bem mais cabível como símile da conduta criativa em literatura do que a arquitetura. Como na tauromaquia, nesse poemapreâmbulo, o limite é seja a morte do autor (toureiro), seja a morte do poema (touro). Esta segunda morte, é a "mumificação", o "pôr em livro o poema", sem que isso signifique que este esteja acabado, mas que somente não se pode mais reformulá-lo.

O poema acima, que lemos através do manuscrito, explicita a tese que concebemos aqui: é preciso incluir, para se pensar o fazer poético de João Cabral, os conceitos de imprevisibilidade e do poema que se faz. O poema é imprevisível e instável porque varia indefinidamente durante o processo de sua composição, através dos "cortes", do "enxertos" e dos "transplantes", que lhe opera o poeta. Essas operações não seguem uma teleologia definida, sendo somente interrompidas pela publicação do texto. Gostaríamos de nas páginas seguintes analisar esses procedimentos operativos por meio da leitura dos protextos de dois poemas do livro A escola das facas: "Prosas da maré na Jaqueira" e "Descoberta da literatura".

488 Obra completa, op. cit., p. 94. 


\section{2. "Cortes" e "transplantes" no manuscrito de "Prosas da maré na Jaqueira"}

Vimos, no subcapítulo anterior, que, no "poema-prefácio" de $A$ escola das facas, "O que se diz ao editor a próposito de poemas", se afirma o inacabamento do processo compositivo, processo que é interrompido somente com a "mumificação" do que se escreve, ou seja, com sua publicação. Isso se coaduna perfeitamente com o fato de alguns poemas de A escola das facas terem passado por ao menos três campanhas de reformulação, depois de inteiramente compostos ${ }^{489}$.

Vimos ainda que, no mesmo poema, são enumeradas, metaforicamente, as operações de escrita. Um poema (ou livro) se amputa, nele se enxerta, nele e dele se transplanta; ou, de outra forma, ele se "multiplica", se divide", se adiciona e se subtrai, "se pratica as quatro operações", enquanto "vive" no e do poeta. Gostaríamos de identificar e analisar tais operações nos manuscritos de alguns poemas de $A$ escola das facas. O manuscrito do próprio poema, infelizmente, só nos dá exemplos de algumas delas. Porém, o mesmo não acontece com outros manuscritos do livro. Escolhemos propositadamente o prototexto do poema "Prosas da maré na Jaqueira" devido à sua riqueza genética. $\mathrm{O}$ documento está transcrito e reproduzido em anexo (ver anexo 10 e nossas "transcrições" no fim da tese). Mostraremos como, depois de composto, através das operações de cortes e transplantes, o poema se transforma completamente.

489 Já nas análises de manuscritos de poemas de Serial e A educação pela pedra, feitas mais acima nesta terceira parte, apontávamos para o fato de os textos terem sido reformulados, inclusive com mudanças estruturais, mesmo depois de estarem completamente compostos. 
Antes, digamos algo, para melhor situarmos a análise dos manuscritos, sobre o sentido geral do texto. Trata-se da rememoração, feita pelo Eu do poema, do fenômeno da "maré" (o encontro do rio Capibaribe com o mar), que contemplava quando criança. O eu-criança é figurado como aluno e o rio como mestre. Assim, tem razão Antonio Carlos Secchin ao afirmar que "poucos poemas, em toda a obra do poeta, são tão confessadamente 'de aprendizagem'" 490 . Porém, o poema é modalizado de tal maneira, que o que foi aprendido pelo poeta é objeto de dúvida, já que o EU se pergunta repetidamente pelo conteúdo da lição. Vejamos.

$\mathrm{Na}$ quarta a parte, primeira em que Eu se pergunta diretamente pelo sentido do que foi aprendido, a qualidade da lição é indecidível:

não sei se foi para o sim ou para o não teu colégio491

$\mathrm{Na}$ quinta, onde se retoma a questão do sentido da aprendizagem, exceto pela recusa da música, o conteúdo da lição é definido apenas negativamente:

Maré do Capibaribe

que ensinaste ao antipoeta

(além de à música ser surdo?)

Nada de métrica larga, gilbertiana, de teu ritmo; nem lhe ensinaste a dicção do verso Cardozo e liso.

Finalmente, na $7^{\mathrm{a}}$ parte, última em que o Eu se pergunta pelo conteúdo da lição aprendida com a "maré, todos os versos são

${ }_{490}$ SECCHIN, Antonio Carlos, João Cabral: a poesia do menos, op. cit., p. 281.

491 Obra completa, op. cit., p. 443. 
interrogativos, e neles alternam-se conteúdos possíveis, sem que se decida categoricamente por um deles:

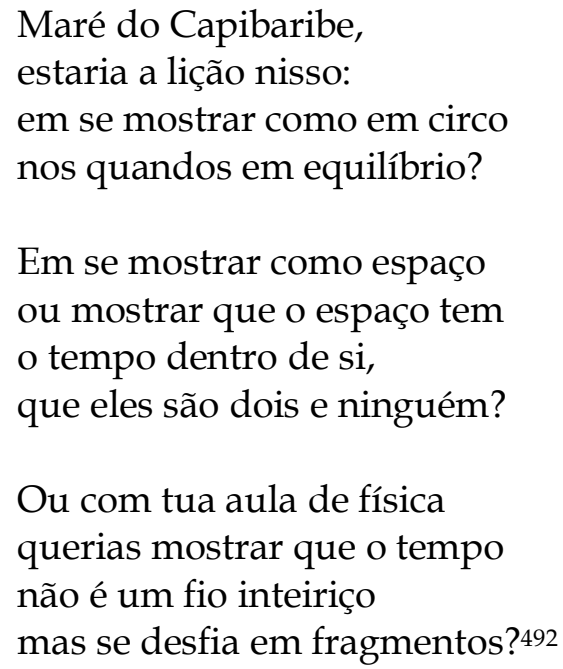

Assim, o Eu parece não saber exatamente a lição aprendida com a maré, apenas que ela tem a ver, sem que o afirme categoricamente, com a percepção do tempo como instável e fragmentário e com sua confusão com o espaço. Veremos que essa modalização dubitativa da enunciação do $\mathrm{Eu}$ não existia na primeira versão do poema. Ao contrário, o valor modal da primeira vesão é assertivo, pois o Eu afirma explicitamente o sentido da lição que aprendeu com o rio. Veremos ainda que não somente muda a modalização, mas o próprio "gênero" do poema, que chegou a se transformar em "canção" e depois foi modificado para "prosas". Essas reformulações vão juntas com uma diminuição e nova disposição das partes do poema.

Comecemos pelo título. Nesse caso, temos a seguinte série de reformulações:

\section{A maré $\rightarrow$ Canções da maré na Jaqueira $\rightarrow$ Prosas da maré na Jaqueira}

492 Obra completa, op. cit., p. 444. 
O primeiro título, presente na versão mais antiga, serve apenas como indicação do objeto do poema. O segundo título, porém, estabelecido na segunda campanha, determina o gênero rítmico do texto: ele é denominado canções. A substituição não foi aleatória. Certas estrofes, algumas depois reformuladas, tinham de fato um caráter musical, de andamento pendular, imitando o ir e vir da cheia da maré na Jaqueira. Por exemplo, na segunda parte da primeira versão, temos:

\section{Teu rio linear de antes viaja duplo, faz refaz: ora te leva onde o mar ora de volta te traz ${ }^{493}$}

Os acentos regulares (primeiro verso: $2^{\mathrm{a}}$ e $7^{\mathrm{a}}$ sílabras; segundo verso: $2^{\mathrm{a}}$, $4^{\mathrm{a}}$ e $8^{\mathrm{a}}$ sílabas; terceiro verso: $4^{\mathrm{a}}$ e $7^{\mathrm{a}}$ sílabas; quarto verso: idem), as rimas sonoras e as repetições sintáticas (ora [...] ora [...]) mostram o quão musical é a estrofe. Pode-se, portanto, dizer que a mudança do primeiro para o segundo título não significa uma mudança de intenção. O poema já havia sido concebido como uma canção, na qual o ritmo está em relação de isomorfismo com o movimento alternante entre maré baixa e maré cheia. $\mathrm{O}$ título "Canções da maré na Jaqueira", portanto, apenas explicita o andamento melódico da composição. É surpreendente que João Cabral, tão "anti-musical”, como não se cansou de dizer, e como ele mesmo afirma neste mesmo poema, tenha realizado uma canção, "gênero" que cultivou somente em seu primeiro livro, Pedra do sono ${ }^{494}$.

\footnotetext{
$493 \mathrm{Ou}$ ainda: (Quandos em que tempo e espaço,/em que às vezes te deténs,/se confundem nesse enquanto/em que tu não vás nem vens).

${ }^{494}$ Cf. as duas "canções" do livro, às pp. 47 e 49 da Obra completa. A segunda, à página 49, também tematiza, ainda que um pouco hermeticamente, as relações entre rio e infância.
} 
Porém, o gênero "canção" é abandonado, como se pode verificar pela mudança radical no título: canções da maré na Jaqueira $\rightarrow$ prosas da maré na Jaqueira. Dessa reformulação desviante não há traço genético. Ela é posterior, porém, ao "transplante" para o texto de passagens prosaicas que substituem outras de andamento melodioso.. Por exemplo, a última estrofe que citamos é substituída por:

Teu rio franzino de antes a areia não bebe mais: é a maré que o bebe agora (não é muito o que lhe dás).

Com a reformulação desaparecem os acentos regulares, a repetição sintática e a rima torna-se imperfeita. A prosificação da estrofe ocorre também por meio de uma elipse na passagem do segundo para o terceiro e do terceiro para o quarto versos.

Uma vez que a reformulação do título para "Canções da maré na Jaqueira" e da estrofe citada para uma versão mais prosaica fazem parte de uma mesma campanha de escrita, como pode ser verificado no manuscrito, haveria uma certa contradição entre as duas reformulações. Pois, por um lado, a primeira mudança, a de título (a maré $\rightarrow$ canções da maré na Jaqueira) explicita o caráter muscial do poema, e, de outro lado, a reformulação da estrofe torna o poema mais prosaico. A "contradição" pode ser resolvida se pensarmos que o autor começa por reformular o título, e, no decorrer da leitura que faz, transforma também algumas estrofes, no sentido de prosificá-las, sem que retorne à modificação do título. A reformulação, então, do título de “canções' para "prosas" deve ter sido feita em uma terceira campanha, (correpondente a um novo "passar a limpo do datilografar"), da qual não temos registro genético, para tornar a titulação condizente com mudança do ritmo. 
De qualquer forma, o que as mudanças de título mostram é que o gênero "prosa", presente no título da versão definitiva, somente é escolhido no decorrer do trabalho de reformulação do poema, que o desvia de uma intenção musical, expressa pelo gênero provisório da "canção", para uma mais prosaica.

Passemos agora à análise das partes do poema a partir da versão mais antiga, o que nos dará a oportunidade de considerar a mudança de modalização (de assertiva, na versão original, para dubitativa, na versão final), e da relação entre as diversas partes que são diminuídas e, algumas, permutadas.

Primeira parte. A relação inicial entre o menino e o rio é de ignorância. Embora tendo nascido "em frente" da maré, a criança ficava "sem saber" que se tratava do rio Capibaribe ("sem saber que /aquele/<o rio> em frente/era o tal Capibaribe". As reformulações efetuam certas mudanças nocionais:

vivo em tudo o que o Recife $\rightarrow$ onde muito em Pernambuco

\section{era o tal Capibaribe $\rightarrow$ era o próprio quase tudo $\rightarrow$ era o próprio- quase-tudo}

Elas amplificam o rio, dando a ele um sentido de imensidão misteriosa (Capibaribe $\rightarrow$ o próprio quase tudo), o que é reforçado pela entificação (o próprio quase tudo $\rightarrow$ o próprio-quase-tudo). Assim, apenas paulatinamente o rio assume uma conotação simbólica ${ }^{495}$, tornando-se símile do próprio mundo.

\footnotetext{
495 O caráter simbólico do rio Capibaribe na obra de João Cabral já foi assinalado por Everton Barbosa Correia em passagem de sua tese que comenta a primeira parte do poema "Prosas da maré do Capibaribe". Citemos: "Ressalte-se que é como elemento simbólico do tipo de sociabilidade que se abateu em terras pernambucanas que o rio aparece reiteradamente no interior da obra cabralina. Agora [no poema "Prosas da
} 
En passant, no manuscrito desta primeira parte pode-se observar um procedimento de escrita curioso de Cabral. Referimo-nos à tentativa da constituição de uma nova rima na estrofe abaixo transcrita, necessária devido à reformulação do $2^{\circ}$ verso.

$\begin{array}{ll}\text { Na história, lia de um rio } & \\ \text { onde muito em Pernambuco } & \\ \text { vivo em tudo o que o Recife, } & \text { estudo } \\ \text { sem saber que o rio em frente } & \text { público } \\ \text { era o [ileg.] quase tudo } & \text { tudo } \\ \text { era o tal Capibaribe. } & \\ \text { próprio } 996 & \end{array}$

A enumeração, ao lado, de palavras com o mesmo paradigma fônico (tônica na vogal $u$ ) mostra como certas soluções rímicas e, logo, semânticas são frutos, não de previsões, mas de tentativas. Não tendo ainda em mente a melhor solução para o verso, o autor lista na margem da folha uma pequena série de palavras como que procurando, por meio de ensaios, uma expressão que coadune som e sentido. A listagem de paradigmas é um mostragem inequívoca de que, por vezes, escrever não é a mera realização de uma intenção clara. Ou seja, nem sempre é no pensamento que se formula a palavra a ser escrita; ela é, digamos, encontrada pela mão na folha do papel. Há outro exemplo desse mesmo procedimento que pode ser observado no fólio 23 do manuscrito (ver anexo 10 e transcrições) ${ }^{497}$.

maré na Jaqueira"], ele se oferece como índice histórico que diz respeito a sua família - que lhe incorpora o estilo - e, por extensão, à própria experiência subjetiva do poeta que nascera numa casa com as janelas abertas para o rio." (A poética do engenho. A obra de João Cabral sob a perspectiva canavieira. Tese: Teoria literária e Literatura comparada. Universidade de São Paulo - USP: 2007, p. 110).

496 Pasta Pi. Poemas pernambucanos, fólio 19.

497 Há outros exemplos desse modo de procurar palavras em Cabral. No manuscrito da terceira parte de "O alpendre no canavial" lemos o seguinte: 
$2^{a}$ parte. O Eu descreve o "estilo" da maré do Capibaribe, estilo por meio do qual esta ensinará o poeta. Na maré, o Capibaribe é "plano e comedido", "ancho", quer dizer, tem um estilo lento e largo, sempre por oposição ao estilo do rio no interior ("saltante e pouco").

Já fizemos um pequeno comentário acima sobre a reformulação da terceira estrofe desta parte, no que toca à mudança da forma rítmica do poema (de canção para prosa) quando tratamos da mudança de título. Citemo-la novamente:

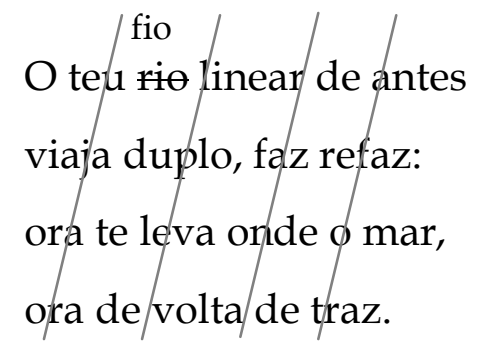

Teu rio franzino de antes

a areia não bebe mais:

é a maré que o bebe agora

(não é muito o que lhe dás). ${ }^{498}$

\section{O tempo se faz tão espêsso}

que revela sua substância,

tão espêssa que ao alpapá-la

se tomaria por membrana././ <,>
É quando se faz tão espêsso

que se pode tocar a matéria

<que dá a tocar sua substância>

grossa membrana se revela
medra
terna
lerda
aérea

Vê-se no exemplo acima que a tentativa de mudança do domínio nocional, a partir do qual o tempo é representado, do visual ("revela") para o tátil ("pode tocar", "dá a tocar" e, finalmente, "palpável", na versão publicada), por motivos métricos, acaba por levar à substituição de "substância" por "matéria". Essa alternativa leva o autor a enumerar uma sequência de palavras com acento tônico no " $\mathrm{e}$ " (medra, terna etc.) que deveriam substituir a palavra "revela" do verso "grossa membrana se revela", com o qual o autor não está satisfeito. Finalmente, nenhuma delas será aproveitada, uma vez que a solução foi substituir "que revela" por "que dá a tocar" e depois por "que é palpável", mantendo-se "substância" que já rimava com "membrana", na primeira versão.

${ }^{498}$ Pasta Pi. Poemas pernambucanos, fólio 20. 
Além da mudança rítmica, muda a própria representação do rio. Na primeira versão, o domínio nocional é o do movimento na modalidade pendular, já que se representa o ir e vir entre maré baixa e maré alta. Na estrofe definitiva o rio é estático, sofrendo passivamente a ação da maré, que o "bebe". Esse movimento pendular será, como veremos, paulatinamente quase apagado do poema.

Terceira parte. A comparação da maré com uma tela de cinema introduz as primeiras impressões retidas pela criança. Na versão mais antiga, o que era "projetado" pela maré se reduzia a uma pura temporalidade em lento fluxo:

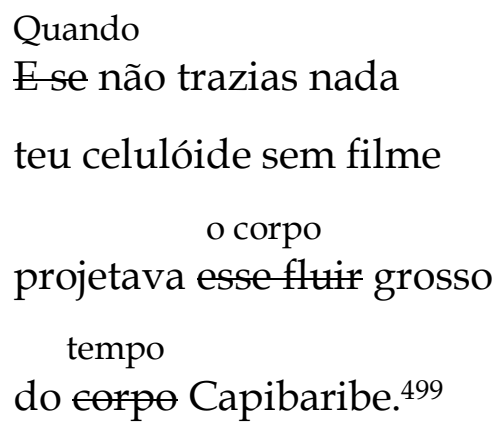

Tratar-se-ia da primeira referência explícita ao tempo lento identificado com a água que tem "passo comedido" -, cujo "fluir grosso" fará com que se confunda com o próprio espaço, mais adiante. É a introdução da "aula de física" que o poeta tentará decifrar.

A quarta e a quinta partes põem as primeiras questões quanto ao verdadeiro sentido da lição da maré. Com respeito à lição de estilo, ela é definida negativamente, como se lê na primeira versão:

499 Pasta Pi. Poemas pernambucanos. Original, sem indicação de fólio. 
Nada de métrica larga claudeliana, de teu ritmo, não the ensinaste a escrever o verso Cardozo e liso 500

Na versão definitiva, a única reformulação dessa estrofe será a substituição de "claudeliana" (uma referência a Paul Claudel, poeta francês), por "gilbertiana" (referência a Gilberto Freire). Mas a lição é a mesma, ou melhor, a não-lição, pois o poeta não era considerado propício ao estilo largo da maré, mais semelhante a um "falar sensual" do que a uma dicção dura.

Sexta parte. Esta parte guarda um interesse especial, na medida em que é a única a ser tranplantada do meio da primeira versão disponível para o fim da versão definitiva. Na primeira versão do poema, como sexta parte, ela marcava uma transição no processo rememorativo do poeta, já que era introduzido o tema do tempo, central no ensinamento aprendido :

dos quandos em frente ao cais

em teu passar

via-te destisar [sic] lento,

um vício, ouvir

veio-me eutre, o de escutar

e sentir passar-me o tempo. 501

Deslocada para o final do poema em sua versão publicada, essa parte será lida, pela crítica, como concentrando "elementos disseminados nas estrofes anteriores: o vínculo entre o rio e a infância

500 Pasta Pi. Poemas pernambucanos. Original, sem indicação de fólio.

501 Pasta Pi. Poemas pernambucanos. Original, sem indicação de fólio. 
do poeta; o passo pesado do Capibaribe, a marcha líquida associada ao fluxo temporal." ${ }^{502}$.

Sétima parte. Primeira referência à espacialização do tempo, através da maré, na medida em que esta, cheia, é pura inércia, perdendo seu movimento e, portanto, seu aspecto temporal:

Maré do Capibaribe

entre a Jaqueira e Santana

há momentos que a maré,

seu ir e vir, te empatana.

Então teu tempo é espaço, água

tua eebra-de passar grosso

é uma água morta, dormida,

paralítica, de poço.

Teu tempo é somente espaço,

és lagoa que se finge

sem nada do fluir duplo

que enche e esvazia o Recife.503

A espacialização do tempo é determinada justamente pelo embaraçamento entre o "ir e vir" da água, seu "fluir duplo". Na versão definitiva (equivalente à sexta parte da versão publicada), ao invés de uma descrição desse tempo espacializado, há a descrição do progressivo estatismo da água do rio - da progressiva transformação do tempo em espaço -, até ser confundida com a água "paralítica" do poço:

502 SECCHIN, Antonio Carlos, João Cabral: a poesia do menos, op. cit., p. 284.

${ }^{503}$ Pasta Pi. Poemas Pernambucanos. Original, sem indicação de fólio 
O tempo se vai freando

até frear, todo espaço,

(lago sem brisa no rosto),

frear de todo, água morta,

paralítica, de poço. 504

Oitava parte. Equivale à sétima parte do poema publicado. Pudemos ver um pouco acima que, na versão definitiva, esta parte se compunha de uma série de interrogações sobre o sentido da "aula de física" (espacialização do tempo) dada pela maré. Na primeira versão disponível, a passagem também se modaliza dubidativamente. Porém, se na versão publicada o Eu considera interrogativamente ao menos três conteúdos possíveis da lição dada pela maré, na versão datiloscrita a interrogação se estende a apenas um, o da água mostrar-se como espaço "nos tempos em equilíbrio", e, assim, deter o tempo no "lago morto" que imita:

estaria a lição nisso:

em se mostrar como espaço

nos quandos em equilíbrio?

Querias deter o tempo

no lago morto que imitas?505

Os "quandos em equilíbrio" são aqueles em que a maré, plena, torna-se completamente estática:

(Quandos em que tempo e espaço, em que às vezes te deténs, se confundem nesse enquanto em que tu não vás nem vens) $)^{506}$

504 Obra completa, op. cit., p. 444.

505 Pasta Pi. Poemas pernambucanos. Original, sem indicação de fólio.

506 Ibidem. 
Observa-se mais uma vez uma imagem pendular ("em que tu não vás nem vens") que será substituída na versão publicada:

Em se mostrar como espaço espaço tem ou mostrar que o tempe

o tempo dentro de si com [ileg.] que ambos são dois e ninguém [ileg.]
(Quandos em que tempo e espaço,

em que às vezes te deténs, se confundem nesse enquanto em que tu não vás nem vens).

Nona parte. Será completamente suprimida como parte integrante do poema, sendo aproveitada apenas indiretamente na reformulação da $7^{a}$ parte da versão publicada. Se pudemos ver que, nesta última versão, a modalização do discurso do Eu é dubitativo, pois ele não consegue determinar de maneira inequívoca o contéudo da lição aprendida com o maré, a $9^{a}$ parte da primeira versão disponível mostra uma modalização inteiramente outra, já que o texto é assertivo e as lições são explicitamente definidas:

Maré do Capibaribe,

tua lição é essa pugna a luta trunca ouvi tua mensagem dupla: na crista mesmo <se> imóvel, no equilíbrio da maré, lembres laguna,

mesmo se tua água espessa, quase músculo, ou de cobra, esteja finja passe em coisa, esteja espaço, és só tempo, muito embora: 
és expressão desse vento,

mais sutil que qualquer brisa,

mas de

que nos sopra, no mais dentro,

[ileg.] [ileg.]

$<$ na $>$ na direção que descria des-cria

[ileg. $]^{507}$

A lição é inequívoca: apesar da imobilidade da maré, sua água é "só tempo". Mas que tipo de tempo? Não o tempo social, mas um tipo inteiramente subjetivado, interiorizado: '"és expressão desse vento,/mais sutil que qualquer brisa/que nos sopra / no mais/ <mas de> dentro". A imagem do tempo-Capibaribe como a expressão de um "vento interno", ou seja, de um tempo completamente subjetivo, está quase ausente da versão definitiva exceto pela referência, nos últimos versos, ao vício, adquirido com a contemplação da maré, do Eu de sentir o tempo passando dentro de si:

veio-me o vício

de sentir passar-me o tempo. ${ }^{508}$

Décima parte. Também completamente suprimida na versão definitiva. Nela, o poeta continua a explicitar assertivamente a lição aprendida com o rio:

Maré do Capibaribe, aprendi <e> ouvi tua outra lição:

embora tu desças, subas, tenhas mão e contra-mão,

507 Pasta Pi. Poemas pernambucanos. Original, sem indicação de fólio.

508 Obra completa, op. cit., p. 445. 
muito mais desces que sobes

da água pouca que te chega,

Capibaribe, e sem mar

no ponto em que o mar, só rio,

no onde em que a maré te deixa.

Capibaribe, te deixes.

Ese Teu rio

Assim, nunca vem de novo,

seu passar é uma só vez.

na maré cheia ou vazia,

O tempo se lê, se vive,

da água tempo que passou

cada

nas várias vezes por dia.

mas não se deixa reler. 509

Se a primeira lição, na $9^{a}$ parte, ensinava que a maré do Capibaribe era a expressão de um tempo interiorizado, a segunda, na $10^{\mathrm{a}}$ parte, ensina, heraclitianamente, que não se entra no mesmo rio duas vezes, quer dizer, que o tempo não se repete. A infância perdeu-se para sempre.

Vimos, assim, com a análise do prototexto de "Prosas da maré na Jaqueira", como, através de intensas reformulações feitas de cortes e transplantes, esse poema se transformou radicalmente. De início composto com 10 partes, concebido como uma “canção' e modalizado assertivamente, estabelecendo-se sem ambiguidades o conteúdo das "lições" (de caráter subjetivo) aprendidas pelo poeta com o fenômeno da maré , o poema acaba por se reduzir a oito partes, muda de gênero rítmico, ao se transformar em "prosas", e modaliza-se, finalmente, dubidativamente, não podendo o Eu determinar positivamente o

509 Pasta Pi. Poemas Pernambucanos. Original, sem indicação de fólio. 
sentido das lições aprendidas com o rio. Dessa forma, por meio sobretudo de "cortes" e "transplantes" o poema é operado embora já "passado a limpo" do datilografar, transformando-se sensivelmente. 


\section{3. Um caso de "enxerto": o manuscrito do poema "Descoberta da literatura"}

Afirma-se comumente que a principal operação de escrita, em João Cabral, é a de "depuração", ou seja, a supressão do que é supérfluo em proveito de uma semântica precisa. A expressão "poesia do menos", formulada por Antonio Carlos Secchin, exprime essa ideia. O manuscrito que analisaremos a seguir mostra, ao contrário, um processo de escrita não por meio de cortes, mas por meio de acréscimos, sem que isso signifique, evidentemente, a inclusão de superfluidades. Os acréscimos servem à mudança da representação contida no poema, no sentido de instaurar um distanciamento do Eu com relação às demais personagens da história que se conta. Referimo-nos ao poema "Descoberta da literatura" cuja primeira versão do poema transcrevemos a seguir.

No dia a dia do engenho, toda semana, durante, me confiavam em segredo: saíu um novo romance. E da feira do domingo me traziam palpitantes para que os lesse e explicasse um folheto de barbante. Sentados na roda morta de um carro-de-boi, sem jante, seguiam o texto guenzo e seu leitor, semelhante, e as mais de mil peripécias preditas pelos feirantes. Embora as coisas contadas fossem as de folhetos antes e nada em pouco variassem nos crimes, no amor, nos lances, o interesse era tão denso 
que o leitor, ou auto-falante,

findava se confundindo

com aquele autor distante:

e findaria algum dia

tal a paixão circundante,

não só leitor: findaria

confundido com o brigante.

(Findaria, se não fossem

contar tudo à Casa-grande:

na moita morta do engenho

um filho-engenho, perante

cassacos do eito e de tudo,

se estava dando ao desplante

de ler letra analfabeta

de sertanejo ou cassange). ${ }^{510}$

Se relacionarmos o comentário seguinte de Thaís Toshimitsu excelente com respeito ao texto tal como publicado - com a primeira versão do poema acima citada, veremos que há um certa "inadequação":

Enquanto o leitor, condescendente e também culpado, tende a se sensibilizar com o gesto generoso do menino que se dispõe a ler para o povo analfabeto, não vê o lado verdadeiramente bárbaro, exposto no preconceito do tratamento dos trabalhadores como gente inculta e estéril, o que também está posto diretamente no poema nas palavras que os designam, mas principalmente reproduzido no medo do menino.511 (o grifo é nosso)

A "inadequação", insistindo que a comentadora não teve acesso ao manuscrito, se deve ao fato de que o receio do menino de ser confundido com a gente do eito simplesmente não existe na primeira versão. O preconceito do menino com relação ao trabalhadores do engenho, visto acertadamente por Thaís Toshimitsu, só existe, bastante tênue, em algumas poucas expressões pejorativas com as quais são referidos os trabalhadores: "cassaco" e "cassange". Somente com a

510 Pasta Pi. Poemas pernambucanos. Original, sem indicação de fólio.

511 TOSHIMITSU, Thaís, O rio, a cidade e o poeta, cit., p. 116. 
reformulação do poema é que serão multiplicados os termos aviltantes. Por exemplo: palpitantes $\rightarrow$ conspirantes, sertanejo $\rightarrow$ corumba.

Note-se também, nesse sentido, o acréscimo no final do poema de dois versos onde os trabalhadores são nomeados como marginais:

como esses cegos de feira nos mais das vezes meliantes.

Mas, principalmente, o medo do menino de ser confundido com aquele mundo de senzala, tão diferente do seu, casa-grande, somente é expresso diretamente com as reformulações escritas à margem do fólio 30 da pasta Pi. Poemas pernambucanos, reformulações que reproduzimos abaixo:

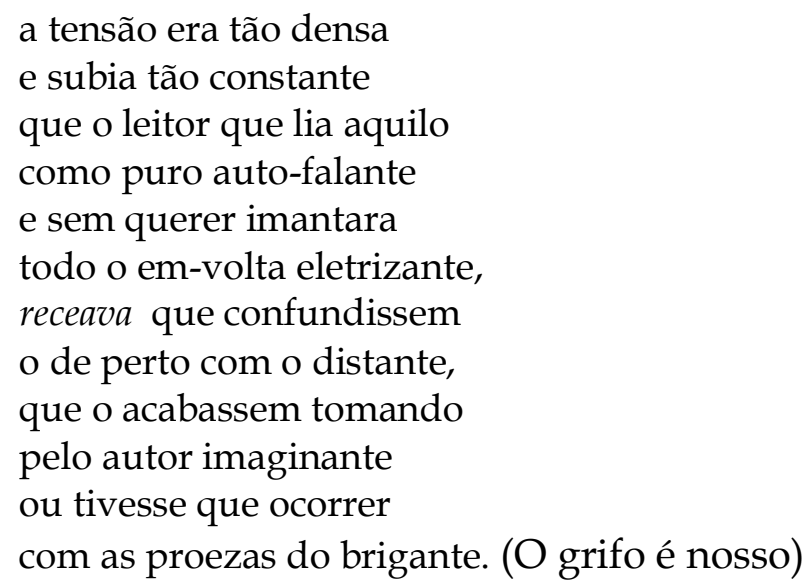

A diferença é total com respeito à primeira versão. Nesta, o leitor "auto-falante", João Cabral menino, acabava por ser identificado com o autor do folheto que lia para os trabalhadores do eito.

O interesse era tão denso que o leitor, ou auto-falante, findava se confundindo com aquele autor distante (O grifo é nosso) 
E é mesmo possível dizer que essa identificação provinha não somente da imaginação dos ouvintes, mas do próprio menino, que, assim, exprimia o precoce desejo se tornar escritor por meio da leitura de uma letra analfabeta.

O distanciamento preconceituoso, portanto, não fazia parte da intenção primeira do autor. Esse fato torna mais agudo o problema da determinação do lugar social do Eu nos poemas de João Cabral, problema bem apontado por Thaís Toshimitsu. O Eu oscila entre sua origem "casa-grande" e sua simpatia pelos do eito. Essa oscilação é flagrante na reescrita do poeta. A simpatia predomina na primeira versão, e, nela, o menino João Cabral tem um lugar entre os trabalhadores confundido que está com o autor dos folhetos por eles apreciados. Essa simpatia, depois, cede ao medo cuja origem está na enorme distância social entre o menino e os cassacos. É impossível responder qual das duas representações - a do menino simpático ou a do menino receoso - era mais próxima da experiência infantil. Mas para os nosso fins basta que seja mostrado aqui que a representação "preconceituosa" é construída somente no decorrer do processo de reformulação através da operação de enxerto.

Analisamos, neste capítulo, os prototextos de alguns poemas dos livros Serial, A educação pela pedra e A escola das facas. O objetivo foi descrever o sentido das diversas operações de reformulação textual efetuadas por João Cabral de Melo Neto em sua prática de escrita. Tal sentido não se reduz à realização de uma intenção inicial conforme um percurso teleologicamente orientado. Isso porque, durante o trabalho reformulativo, o autor, além de produzir sucessivamente paráfrases que dão à luz um texto mais preciso com relação ao texto de origem, 
também formula um outro texto diferente, tanto localmente, quanto estruturalmente, o que aponta para uma mudança de intenção, ou projeto, no decorrer do processo. Essa mudança não condiz com a conduta arquitetônica, se se considera esta como prevalência do desenho sobre o canteiro, pois fere o princípio de economia: com efeito, destruir pilastras já levantadas é, em arquitetura, contra-producente. Mesmo em livros mais rigorosamente "arquitetados", como A educação pela pedra, vimos que o canteiro é, pelo menos do ponto vista microestrutural, anterior ao projeto, já que este é desenhado depois da construção dos poemas, que passam por reformulações intensas. A metáfora arquitetônica fica, porém, completamente prejudicada se se consideram os manuscritos de poemas do livro A escola das facas. As operações de reformulação, que aí são nomeadas, por João Cabral, de "corte", "enxerto", "transplante”, seguem uma lógica não de acabamento, mas de inacabamento do poema, o que o distancia da teleologia projetual, onde o fim da obra pode ser verificado através de sua correspondência com o que foi projetado. Diferentemente, Cabral fala de uma instabilidade inerente à obra que em processo de feitura, cujo único fim possível é a "mumificação" em livro. Enquanto não publicado, o texto poético é, para usar uma expressão do próprio autor, “um poema sempre se fazendo" 512 .

512 Confira o poema "Cenas da vida de Joaquim Cardozo" (Obra completa, op. cit., p. $621)$. 
CONCLUSÃO 
A determinação da natureza do fazer literário de João Cabral de Melo Neto passou aqui pelo exame de seu pensamento sobre criação e de sua prática criativa. Tentou-se, sobretudo, harmonizar um com a outra.

Tanto a poiética, com sua fenomenologia da criação que a descreve como um processo repetitivo no qual a diferença é instaurada por meio de desvios e retificações, quanto a crítica genética através do conceito de reformulação parafrásica como produção de equivalências e assimetrias textuais que transformam e mesmo constituem as intenções de significação, possibilitaram nossa tentativa.

A poiética levou-nos a atentar para textos de Cabral onde tanto o imprevisível quanto o instável eram integrados ao fazer literatura. Esses textos não foram devidamente considerados pela crítica literária dedicada ao poeta. Eles não lhe interessavam porque para a crítica a pergunta pelo procedimento criativo de Cabral já tinha uma resposta bem asssentada: João Cabral seria um "poeta-arquiteto", que projetava calculadamente sua obra e a realizava com rigor transformando a palavra em "pedra", quer dizer, instrumentalizando a linguagem para que bem se concretizasse o que fora projetado. $\mathrm{O}$ processo seria previsível e estável, controlado pela racionalidade construtivista.

Porém, representar o fazer literário cabralino através de uma arquitetura dotada de tal lucidez projetiva é esquecer o triste lamento do arquiteto Anfion diante de sua obra, já que desejou uma cidade aérea e obteve uma "de tijolos plantada". Enquanto Anfion se lamenta, o canteiro ri do projeto. Se a metáfora da arquitetura deve ser utilizada, o controle projetual tem de ser relativizado, porque há surpresas no processo de edificação.

Mas vimos que há em Cabral imagens que representam o fazer muito diferentemente da arquitetura. As metáforas vitalistas da criação, 
por um lado, mostram a força criadora como indomável, e o poema que se faz, tal como na tauromaquia, só é "parado" quando "morto" ("mumificado" em livro) - se não morre o próprio poeta-toureiro. Por outro lado, mas no mesmo espírito, a imagem do fazer como re-fazer incessante, nesse mundo sem preceitos poéticos, mostra que o processo compositivo se esvaziou de um telos que estabiliza o ponto final, e o poema mil vezes se faz e desfaz e refaz como não pode acontecer com um edifício, devido a um princípio de economia.

Sobretudo a ideia de um re-fazer contínuo, de uma instabilidade intrínseca ao poema, de uma imprevisibilidade do fim, foi aqui explorada. Explorada através de uma leitura poieticamente orientada do poemas de João Cabral.

A crítica genética, por sua vez, levou-nos aos manuscritos do poeta, à procura dos traços de sua conduta criativa. E nos seus manuscritos encontramos poemas em estado avançado de composição, nos quais, no entanto, a operação reformulativa introduziu tanto mudanças de sentido quanto de estrutura. Mesmo a composição de um livro julgado como rigorosamente arquitetônico, A educação pela pedra, se conseguimos mostrá-lo, não escapou da paráfrase desviante. Temos dificuldade de pensar que re-compor poemas já compostos seja conforme à conduta de um arquiteto. Reformulação paráfrasica nos parece um conceito mais decoroso, no caso de Cabral, que "arquitetura" ou "engenharia" para descrever o processo compositivo. E substituir, acrescer, suprimir, deslocar formas linguísticas durante a feitura do poema, de tal maneira que este se transforma profundamente, tem uma carga processual mais pesada que a programática.

Com a poiética nos orientando na busca pelo pensamento de Cabral sobre a criação, e com a crítica genética nos fornecendo meios 
para o exame de seus traços manuscritos, acreditamos que a três partes deste trabalho se articulam de forma coesa.

Muito há a fazer com os documentos genéticos constantes do arquivo de João Cabral de Melo Neto, praticamente inexplorados. A descoberta de manuscritos de livros anteriores a Serial, e mesmo de outros que completem os analisados aqui, enriqueceria enormemente uma pesquisa sobre processo de criação cabralino. Mas mesmo considerando apenas os documentos localizáveis na Fundação Casa de Rui Barbosa, há grandes perspectivas de trabalho a fazer. Vários manuscritos não foram sequer mencionados nesta tese, e que propiciariam estudos genéticos importantes. E uma edição genética do dossiê de $A$ educação pela pedra seria desejável pela riqueza da documentação.

O contributo dessa tese, talvez, foi trazer à tona os prototextos do poeta e propor uma nova imagem de sua conduta criativa.

Porém, saindo do restrito âmbito dos estudos cabralinos, nossa tese quis também contribuir para uma maior inteligibilidade do que é fazer literatura em geral. Antes de tudo, é preciso escapar das ilusões provindas das metáforas. A conduta projetual completamente controlada, que existe de fato em arquitetura - se o canteiro não apronta das suas -, como símile do fazer poético, pode ser considerada um mito. Como é um mito o poeta inspirado que nada domina, ao contrário, é dominado por forças sobrenaturais. E bem sabemos que a metáfora técnica e a metáfora teológica (a "inspiração divina") dominam a teoria da criação literária. Essa tese tentou propor uma imagem mais realista desse esforço intenso e sem garantias de realização que é o escrever. Pensar linguisticamente esse trabalho com a linguagem, que é o fazer literatura, é um dos resultados dessa tentativa. Uma visão realista do criar literário também recusa a ilusão retrospectiva que compreende o 
processo compositivo a partir do resultado final. Como um poema tão bem composto não é o produto de uma conduta arquitetônica? Pois não é. É resultado de uma conduta... literária. O teórico preocupado com o fenômeno da criação deve ser capaz de compreender pela própria experiência o que é fazer um poema. Deve ser capaz de compreender que as palavras não são pedras que se encaixam em um desenho projetivo e que tampouco são ditadas pelo inconsciente ou pelos deuses. Mas que há uma plasticidade inerente a esse material, de tal maneira que ele pode ser indefinidamente modificado por meio de um esforço constante. Daí a importância de um estudo sistemático das operações de instauração do sentido e de estruturas - substituir, acrescer, suprimir, deslocar - na medida em que, por elas, pode-se apreender os atos do sujeito criador e as possibilidades plásticas do material linguístico. E não somente os métodos da fenomenologia poiética e da análise genética, mas também os resultados a que ambas chegaram até agora são de grande ajuda para uma maior inteligibilidade do fenômeno criativo em literatura. Esta tese pretendeu ser uma colaboração nesse mesmo sentido. 


\section{BIBLIOGRAFIA}




\section{João Cabral de Melo Neto}

\section{Obras}

MELO NETO, João Cabral. A educação pela pedra e depois. Rio de Janeiro: Nova Fronteira, 1997.

. Obra completa. Rio de Janeiro: Nova Agullar,

1994.

. Poesia critica. Rio de Janeiro: José Olympio,

1982.

. Serial e antes. Rio de Janeiro: Nova Fronteira, 1997.

\section{Documentos manuscritos}

SECCHIN, Antonio Carlos. Um inédito de João Cabral. Colóquio-Letras. Paisagem tipográfica. Homenagem a João Cabral de Melo Neto (1920 - 1990), 2000, nº 157/158, sem indicação de página.

Pasta Pi. A educação pela pedra 1. Arquivo literário de João Cabral de Melo Neto, Fundação Casa de Rui Barbosa.

Pasta Pi. A educação pela pedra 2. Arquivo literário de João Cabral de Melo Neto, Fundação Casa de Rui Barbosa. 
Pasta Pi. Entrevista dada à Manchete. Original. Arquivo literário de João Cabral de Melo Neto, Fundação Casa de Rui Barbosa.

Pasta Pi. Poesia partida em quatro. Arquivo literário de João Cabral de Melo Neto, Fundação Casa de Rui Barbosa

Pasta Pi. Poemas pernambucanos 1. Arquivo literário de João Cabral de Melo Neto, Fundação Casa de Rui Barbosa.

Pasta Pi. Poemas pernambucanos. Arquivo literário de João Cabral de Melo Neto, Fundação Casa de Rui Barbosa

Pasta Pi. Serial. Arquivo literário de João Cabral de Melo Neto, Fundação Casa de Rui Barbosa.

\section{Correspondência/bibliografia}

Pasta Correspondência com Guimarães Rosa. Arquivo literário de João Cabral de Melo Neto, Fundação Casa de Rui Barbosa.

Pasta Correspondência com José Guilherme Merquior. Arquivo literário de João Cabral de Melo Neto, Fundação Casa de Rui Barbosa.

Pasta Correspondência com Murilo Mendes. Arquivo literário de João Cabral de Melo Neto, Fundação Casa de Rui Barbosa. 
CASTELLO, José. João Cabral de Melo Neto: o homem sem alma. Rio de Janeiro: Rocco, 1996.

SÜSSEKIND, Flora. (org.). Correspondência de Cabral com Bandeira e Drummond. Rio de Janeiro, Nova Fronteira e Fundação Casa de Rui Barbosa, 2001.

VASCONCELOS, Selma (org.), João Cabral de Melo Neto: Retrato falado do poeta. Recife: Editora CEPE, 2009.

\section{Discografia}

João Cabral de Melo Neto - por ele mesmo. Festa, CD IG 1013, 2000. (Gravação de 1969.)

\section{Entrevistas}

MELO NETO, João Cabral de. O pedreiro do verso", entrevista a José Geraldo Couto. Folha de São Paulo (Mais!), 22/05/1994.

- "O engenheiro do verso", entrevista a

Hermes Rodrigues Nery. Jornal da Tarde (Caderno de Sábado). São Paulo, 20/05/1989.

ATHAYDE, Félix de. Idéias fixas de João Cabral de Melo Neto. Rio de Janeiro: Nova Fronteira/FBN/UMC, 1998. 


\section{Sobre o autor}

\section{Teses e dissertações}

ALMEIDA, Valéria Paz de Almeida. A retórica da pedra. Análise da argumentação no discurso poético de João Cabral de Melo Neto, 196 p. Mestrado: Língua portuguesa: Universidade de São Paulo - USP: 2001.

BEDIN, Olivo. O fazer poético de João Cabral de Melo Neto e de Fernando Pessoa, 199 p. Tese: Estudos comparados de literaturas de língua portuguesa: Universidade de São Paulo - USP: 2009.

CARVALHO, Claudina Fialho de. Em perfil: João Cabral de Melo Neto e Paul Valéry, 172 p.. Mestrado: Língua e literatura francesa: Universidade de São Paulo - USP: 2004.

CORREIA, Everton Barbosa, A poética do engenho. A obra de João Cabral sob a perspectiva canavieira, 258 p. Tese: Teoria Literária e Literatura Comparada. Universidade de São Paulo - USP: 2007.

OLIVEIRA, Waltencir Alves de, O gosto dos extremos. Tensão e dualidade na poesia de João Cabral de Melo Neto de Pedra do Sono a Andando Sevilha, 203 p. Tese: Teoria Literária e Literatura Comparada: Universidade de são Paulo - USP: 2008.

PEREIRA, Rubens Edson Alves, João Cabral e Miró: imanência do traço, transcendência da pedra, 346 p. Tese: Literaturas de língua portuguesa: PUC/Rio de Janeiro: 1999. 
ROCHA, Francisco José Gonçalves Lima. La poétique de João Cabral de Melo Neto. Poèmes sur des écrivains français, 82 p, sob a orientação de Maria Helena Araújo CARREIRA. Master 2: Études Portugaises, Brésiliennes et de l'Afrique Lusophone: Universidade Paris 8: 2006.

TOSHIMITSU, Thaís Mitiko Taussig. O rio, a cidade e o poeta. Impasses e contradições na poesia de João Cabral de Melo Neto, 202 p. Tese: Teoria Literária e Literatura Comparada: Universidade de São Paulo - USP: 2009.

\section{Livros e artigos}

BAPTISTA, Abel Barros. O livro agreste. Campinas: Editora da Unicamp, 2005.

BARBOSA, João Alexandre. A imitação da forma. Uma leitura de João Cabral de Melo Neto. São Paulo, Livraria Duas Cidades, 1975.

. Alguma crítica. São Paulo: Ateliê, 2002.

CAMPOS, Augusto de et al. Teoria da poesia concreta. São Paulo: Brasiliense, 1987.

CAMPOS, Haroldo de. O geômetra engajado. In: Metalinguagem e outra metas. São Paulo: Perspectiva, 1992. 
CANDIDO, Antonio. Notas de crítica literária - Poesia do Norte. In: Textos de intervenção. Seleção, apresentação e notas de Vinicius Dantas, São Paulo, Duas Cidades, 2002.

CARONE, Modesto. A poética do silêncio: João Cabral de Melo Neto e Paul Celan. São Paulo: Perspectiva, 1979.

ESCOREL, Lauro. A pedra e o rio. Rio de Janeiro: ABL, 2001.

FERRAZ, Eucanaã. Anfion, arquiteto. Colóquio-Letras. Paisagem tipográfica. Homenagem a João Cabral de Melo Neto, julho/dezembro 2000, n's $157 / 158$.

GONÇALVES, Aguinaldo. Miró/João Cabral: da tela ao texto. São Paulo: Iluminuras, 1989.

LEITE, Sebastião Uchôa. João Cabral e a tripa. In: Crítica de ouvido. São Paulo: Cosac e Naify, 2003.

LIMA, Luiz Costa. João Cabral: poeta crítico. In: Intervenções. São Paulo: Edusp, 2000.

- Lira e antilira. Mário, Drummond, Cabral, Rio de Janeiro: Topbooks, 1995.

LUCAS, Fábio. O poeta e a mídia: Carlos Drummond de Andrade e João Cabral de Melo Neto. São Paulo: Senac, 2002.

MERQUIOR, José Guilherme. A astúcia da mímese. Rio de Janeiro: Topbooks, 1997. 
NUNES, Benedito. João Cabral de Melo Neto. Rio de Janeiro, Vozes, 1972

PEIXOTO, Marta. Poesia com coisas: uma leitura de João Cabral de Melo Neto. São Paulo: Perspectiva, 1983.

PRADO, Antonio Lázaro de. Rosa tetrafoliar: uma leitura de A educação pela pedra a partir de seus módulos poéticos-gerativos. in Revista Eletrônica de Humanidades

Http://publicacoes.unigranrio.edu.br/index.php/reihm/article/viewFile/34 $/ 72$.

SECCHIN, Antonio Carlos. João Cabral: a poesia do menos. São Paulo, Livraria Duas Cidades/Pró Memória e Instituto Nacional do Livro, 1985.

SOUZA, Helton Gonçalves, A poesia crítica de João Cabral de Melo Neto, São Paulo, Annablume, 1999.

SUSSEKÏND, Flora. A voz e a série. Rio de Janeiro/Belo Horizonte: Sette Letras/UFMG, 1998

TENÓRIO, Waldecy. A bailadora andaluza. São Paulo: Ateliê/Fapesp, 1996.

VILLAÇA, Alcides. Expansão e limite da poesia de João Cabral. In: Alfredo Bosi (org.). Leitura de poesia. São Paulo: Ática, 1996 


\section{Bibliografia teórica}

ADAM, Jean-Michel. Eléments de linguistique textuelle. Théorie et pratique de l'analyse textuelle. Liège : Mardaga, 1990.

ANOKHINA, Olga e PÉTILLON, Sabine (dir.). Critique génétique. Concepts, méthodes, outils. Paris : Imec, 2009.

ARISTÓTELES. Métaphysique. Traduction de Jean Tricot. Paris: Vrin, 1986.

. Métaphysique. Livres Z à N. Nouvelle traduction du grec ancien par Bernard Sichère. Paris : Pocket, 2010.

. Metafísica, Livros VII-VIII. Tradução de Lucas Angioni. Campinas: IFCH/Unicamp, 2001.

ARRIVÈ, M. GAYDET, F. e GALMICHE, M. La grammaire aujourd'hui. Paris: Flammarion, 1986.

AZEREDO, José Carlos de. Gramática Houaiss da lingua portuguesa. São Paulo : Houaiss e Publifolha, 2010.

BELLAMIN-NOËL, Jean. Le texte et l'avant-texte. Paris: Larousse, 1972

BERTI, Enrico. Philosophie de la forme. Eidos, idea, morphé dans la philosophie grecque des origines à Aristote. Louvain : Peeters, 2003. 
BIASI, Pierre-Marc de, "Flaubert et la poétique du non-finito". In : Le manuscrit inachevé/ed. por Louis HAY. Paris : Éditions du CNRS, 1986.

«L'Elaboration du problématique dans «La légende de Saint Julien l'Hospitalier ». In: Flaubert à l'œuvre. Paris: Flammarion, 1980.

BOSI, Alfredo. História concisa da literatura brasileira. São Paulo: Editora Cultrix, 1970.

BOURDIEU, Pierre. As regras da arte. Gênese e estrutura do campo literário. São Paulo: Companhia das letras, 1996. (Título original: Les règles de l'art. Genèse et structure du champ littéraire. Paris: Éditions du Seuil, 1992.)

CARREIRA, Maria Helena Araújo. Deixis e proxémica verbal. Percursos enunciativos e processos discursivos. Disponível em ler.letras.up.pt/uploads/ficheiros/6690.pdf

Modalisation linguistique en situation d'interlocution : proxémique verbale et modalités en portugais. Louvain : Editions Peeters, 1997.

- Semântica e discurso. Estudos de linguística portuguesa e comparativa (portuguê/francês), Porto: Porto Editora, 2001.

CHATEAU, Dominique "Poïétique et esthétique". Recherches poïétiques, $1996, n^{\circ} 5$. 
COLLIOT, Michel. «L'inachèvement perpétuel ». Artigo disponível em: http://www.universalis.fr/encyclopedie/francis-ponge/5-1inachevement-perpetuel/.

CONTE, Richard. "La poïétique de Paul Valéry". Recherches Poïétiques, $1996, n^{\circ} 5$.

CULIOLI, Antoine. "Préface ». In: La genèse du texte: les modèles linguistiques/ed. por Louis HAY. Paris: Éditions du CNRS, 1987.

DELEUZE, Gilles. Logique du sens. Paris: Seuil, 1967.

FENOGLIO, Irène. Du texte avant le texte. Formes génétiques et marques énonciatives de pré-visions textualisantes, Langue Française, Paris, 2007, $\mathrm{n}^{\mathrm{o}}$.

FEHRMAN, Carl. Poetic creation. Inspiration or craft. Minnesota: University of Minnesota Press, 1980.

FERRO, Sérgio. Arquitetura e trabalho livre. São Paulo: Cosac Naify, 2006. A história da arquitetura vista do canteiro. Três aulas de Sérgio Ferro. São Paulo: GFAU, 2010.

FRANCKEL, Jean Jacques. Introduction. Langue Française. Le lexique, entre identité et variation, 2002, nº 133.

FUCHS, Catherine. «Élements pour une approche énonciative de la paraphrase dans les brouillon de manuscrits ». In : La genèse du texte : les 
modèles linguistiques/ed. por Louis HAY. Paris: Editions du CNRS, 1982. . La paraphrase. Paris : PUF, 1982.

Paraphrase et énonciation. Paris : Ophrys, 1992.

FUCHS, Catherin. GRÉSILLON, Almuth, LEBRAVE, Jean-Louis, «Flaubert : « ruminer Herodias ». In : Genèse et variantion textuelle/ed. por Louis HAY. Paris : Editions du CNRS, 1991.

GENETTE, Gérard. Fiction et diction. Paris : Seuil, 1991.

GILSON, Étienne. Introduction aux arts du beau. Qu'est-ce que philosopher sur l'art? Paris : Vrin, 1963.

GRÉSILLON, Almuth, Élements de critique génétique, Paris: PUF, 1994 . Mise en oeuvre, Itinéraires génétiques. Paris : CNRS Éditions, 2008.

. "Nous avançons toujours sur des sables mouvants." Espaces et frontières de la critique génétique". In : La création in acte. Devenir de la critique génétique/ dir. de Paul GIFFORD e Marion SCHIMD. Amsterdã, Rodopi, 2007.

GRÉSILLON, Almuth, LEBRAVE, Jean-Louis, «Linguistique et génétique des textes: un décalogue». Disponível em http:// www.item.ens.fr/index.php?id=384099. 
Paraphrases et ambiguïtés

dans la production du texte littéraire. In : L'ambigüité et la paraphrase . Opérations linguistiques, processus cognitifs, traitements automatisés/ed. por Catherine FUCHS. Caen : Centre de Publications de l'Université de Caen, 1988.

GRÉSILLON, Almuth, LEBRAVE, Jean-Louis e VIOLLET, Catherine.“Une histoire à dormir debout. Le jeu des paraphrases dans les Cahiers de Proust". In : Proust à la lettre. Les intermittences de l'écriture. Tusson (Charente) : Du Lérot, 1990.

GUÉRIN, Michel. L'espace plastique. Paris : Éditions La Part de l'oeil, collection "Théorie", 2008.

L'artiste ou la toute-puissance des idées. Publications de l'Université de Provence, 2007

GUILLERME, Jacques. Sur la poïétique architecturale. In: Recherches poïétiques/org. René PASSERON. Paris: Éditions du CNRS, 1975.

GUIMARÃES, Eduardo. Texto e argumentação. Um estudo de conjunções do português. Campinas: Pontes, 2007.

HAY, Louis. A literatura dos escritores. Questões de crítica genética. Belo Horizonte : Editora UFMG, 2007.

- Critique génétique: origine et perspectives. In: Essais de critique génétique/ed. por Louis HAY. Paris : Flammarion, 1979. 
HEIDEGGER, Martin. Aristote, Métaphysique théta 1-3. Paris : Gallimard, 1991.

LAHAIE, Cristiane, WATTEYNE, Nathalie. Lecture et écriture: une dynamique. Objets et défis de la recherche en création littéraire. Québec: Editions Nota Bene, 2001.

LEBRAVE, Jean-Louis. "La critique génétique : une discipline nouvelle ou un avatar moderne de la philologie ? ». Genesis, 1992, nº 1.

L'écriture interrompue: quelques problèmes théoriques. Le manuscrit inachevé. Écriture, création, communication/ed. por Louis HAY. Paris : Éditions du CNRS, 1986.

LE CORBUSIER. Por uma arquitetura. São Paulo: Perspectiva, 1998.

LEIRIS, Michel. La literatura considerada como una tauromaquia. Barcelona: Tusquets Editor, 1975. (Originalmente publicado em L'âge de l'homme. Paris: Gallimard, 1946).

Le mode mineur de la création/dir. de Richard CONTE. Nice : Z'Éditions, 1995.

LENAIN, Thierry. Le savoir historique comme paramètre objectif de la création artistique contemporaine. Recherches poḯtiques, 1996, nº 1.

LINS, Osman. Guerra sem testemunhas. O escritor, sua condição e a realidade social, São Paulo: Editora Ática, 1974. 
LUCAN, Jacques. Composition, non-composition, Architecture et théories. XIXème - XXème siècles, Lausanne, Presses Polytechniques et Universitaires Romandes, 2010.

MARITAIN, Jacques. Art et scolastique. Paris : Desclée De Brouwer, 1965.

NEVES, Maria Helena de Moura. Gramática dos usos do português. São Paulo: Editora Unesp, 2000.

NITRINI, Sandra Margarida. Literatura comparada (História, teoria e crítica). São Paulo: Edusp, 2010. - Poéticas em confronto (Nove, novena e o Novo Romance). São Paulo: Hucitec, 1987.

NONNENMACHER, Georges. Du poème à la poḯtique, Manouba, Publications de la Faculté de Lettres de la Manouba, 1990.

PASSERON, René. “Création e genèse”. Recherches Poïétiques, 2000 n9. ."Esthétique et poïétique". Recherches poïétiques, $1998 / 1999, \mathrm{n}^{\circ} 8$ ."Editorial”. Recherches poiétiques, 1994, nº 1. . Exclamations philosophiques, suivi de Thèmes, Paris: L »Harmattan, 2003. . La naissance d'Icare: élements d'une poïétique général. Valenciennes: ae2cg Éditions, 1996. 
. La poïétique, Revue d'esthétique, 1971, nº 3.

Poèmes laconiques. Paris: Cahiers de l'atelier, 1995.

. Pour une philosophie de la création. Paris: Klincksieck,

1989.

PINO, Claudia Amigo Pino; ZULAR, Roberto. Escrever sobre escrever: uma introdução crítica à crítica genética. São Paulo: Martins Fontes, 2007.

PLATÃO. Il sofista, a cura de Mario Vitali. Milão:Tascabili Bompiani, 1992.

Le banquet. Présentation et traduction de Luc Brisson, Paris :

Flammarion, 2005.

. Le sophiste. Traduction de Nestor Cordero. Paris:

Flammarion, 1993

Poiétique et culture/dir. de René PASSERON. Sfax, Biruni, Paris: Arcantère, 1994.

POTTIER, Bernard. La paraphrase textuelle dans ses fondements théoriques. Cahiers de linguistique hispanique médiévale, 1990, n 14-15, Paris : Klincksieck.

Représentations mentales et catégorisations linguistiques.

Louvain - Paris, Editions Peeters, 2000. 
Sémantique générale, Paris, PUF, 1992.

.Théorie et analyse en linguistique, Paris, Hachette, 1992.

QUINTILIEN. Institution oratoire. Paris: Les Belles Lettres, 1980.

Recherches poïétiques. Tome I : la poïétique/dir. de René PASSERON. Paris : Klincksieck, 1975.

Recherches poḯtiques tome II : le materiau/dir. de René PASSERON. Paris : Klincksieck 1976.

Recherches poïétiques tome III : la création collective/dir. de René PASSERON. Paris : Clancier Guénau, 1981.

Recherches poḯtiques tome IV: Création et répétition/dir. de René PASSERON. Paris : Clancier Guénau, 1982.

Recherches poiétiques tome $V$ : la présentation/dir. de René PASSERON. Paris : Éditions du CNRS, 1985.

RIOS FILHO, Adolfo Morales de los. Teoria e filosofia da arquitetura. Rio de Janeiro: Editora À Noite, 1955.

ROE, John e STANCO, Michele (eds). Inspiration and technique: ancient to modern views on beauty and art. Berna: Peter Lang, 2007.

SALLES, Cecília Almeida. Redes da criação: construção da obra de arte. São Paulo: Editora Horizonte, 2006. 
SIMONNET, Cyrille. Dessin-chantier. Réflexions sur la genèse de l'oeuvre architecturale. Genesis, 2000, nº 14,

SCOPELLITTI, Paolo. Les avant-textes de l'Imaculée conception. In : La fabrique Surrealiste/ed. por Maryse VASERVIÈRE, Éditions du CNRS. Disponível em $\quad \underline{\text { htp: } / / \text { melusine.univ- }}$ paris3.fr/Association/ImagesAssoc/Fabrique_BAT.pdf.

SISSA, Gulia. La génération automatique. In : L'animal dans l'antiquité. CASSIN, B. et LABARRIÈRE, J. -L. (org.). Paris : Vrin, 1997.

SOURIAU, Etienne. Vocabulaire d'Esthétique. Paris : PUF, 1990.

STEINER, George. Gramáticas de la creación. Madrid: Ediciones Siruela, 2005. (Título original: Grammars of creation. New Haven: Yale University Press, 2004)

TADIÉ, Jean-Yves, Proust et l'inachèvement. IN : Le manuscrit inachevé/ ed. por Luis HAY. Paris : Éditions du CNRS, 1986.

VALERY, Paul, Oeuvres 1, Paris, Gallimard, 1957.

VALÉRY, Paul. Oeuvres II. Paris: Gallimard, 1960.

WILLEMART, Philippe. Critique génétique: pratiques et théorie. Paris: L'Harmattan, 2007.

WITTGENSTEIN, Ludwig. Investigações filosóficas. Petrópolis: Vozes, 1994. 
ANEXOS 
Cópias fotográficas 


\section{Anexo 1: "Velório de um comendador"}

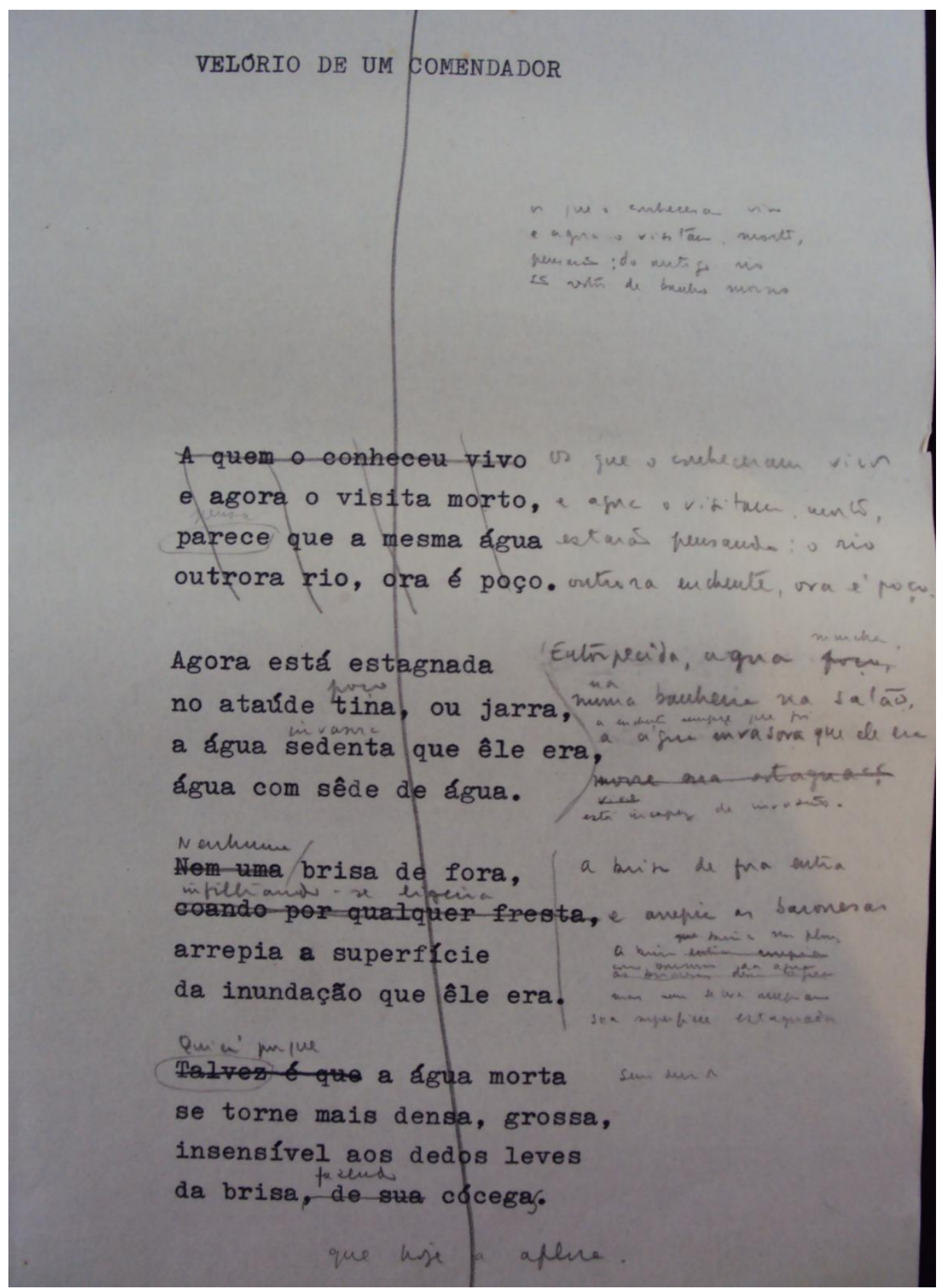

Datiloscrito reformulado da primeira parte do poema. Pasta Pi. Serial, fólio 41 recto. Arquivo literário de João Cabral de Melo Neto, Fundação Casa de Rui Barbosa. 


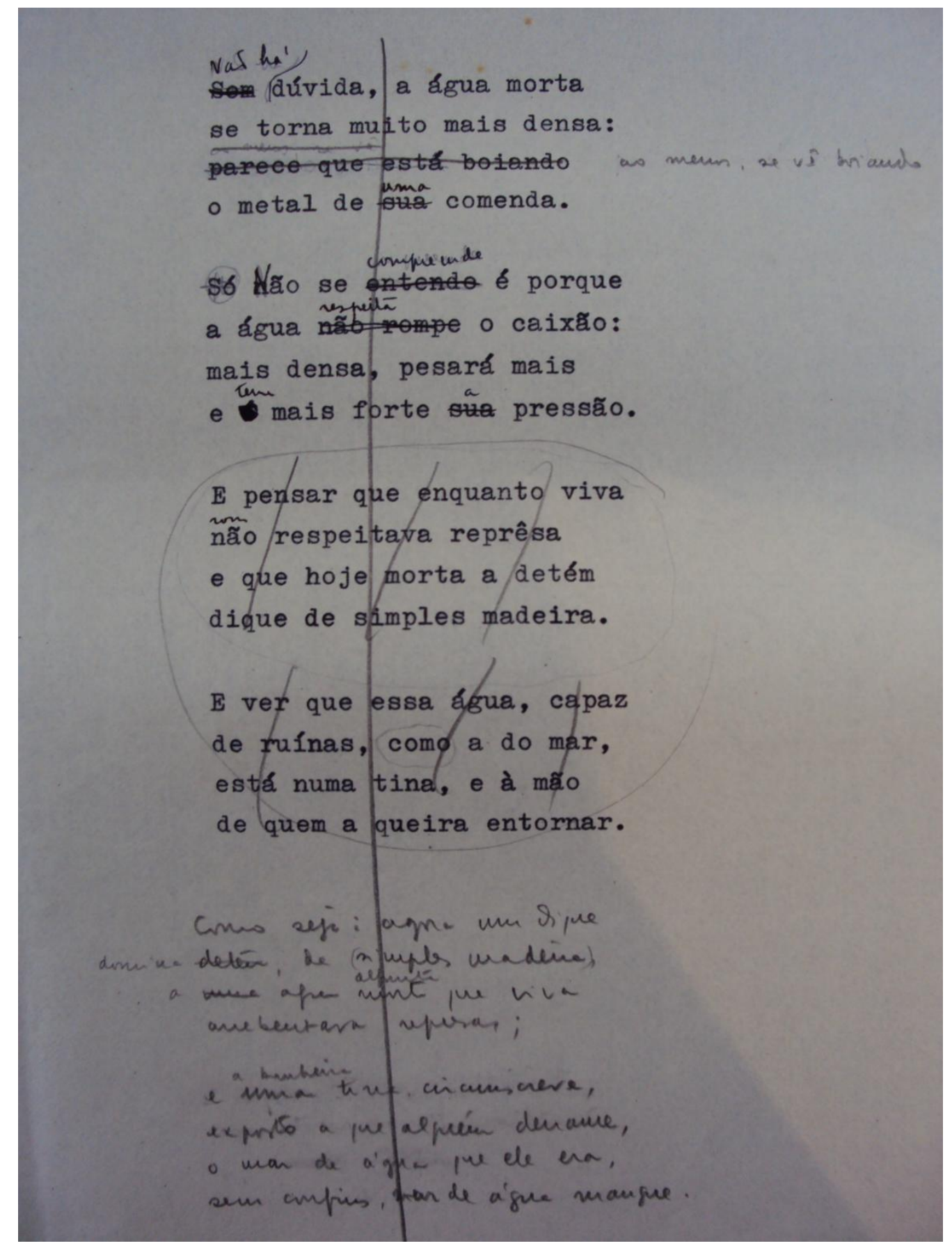

Datiloscrito reformulado da primeira parte do poema “. Pasta Pi. Serial, fólio 42, recto. Arquivo literário de João Cabral de Melo Neto, Fundação Casa de Rui Barbosa. 


\section{Anexo 2: "Escritos com o corpo"}

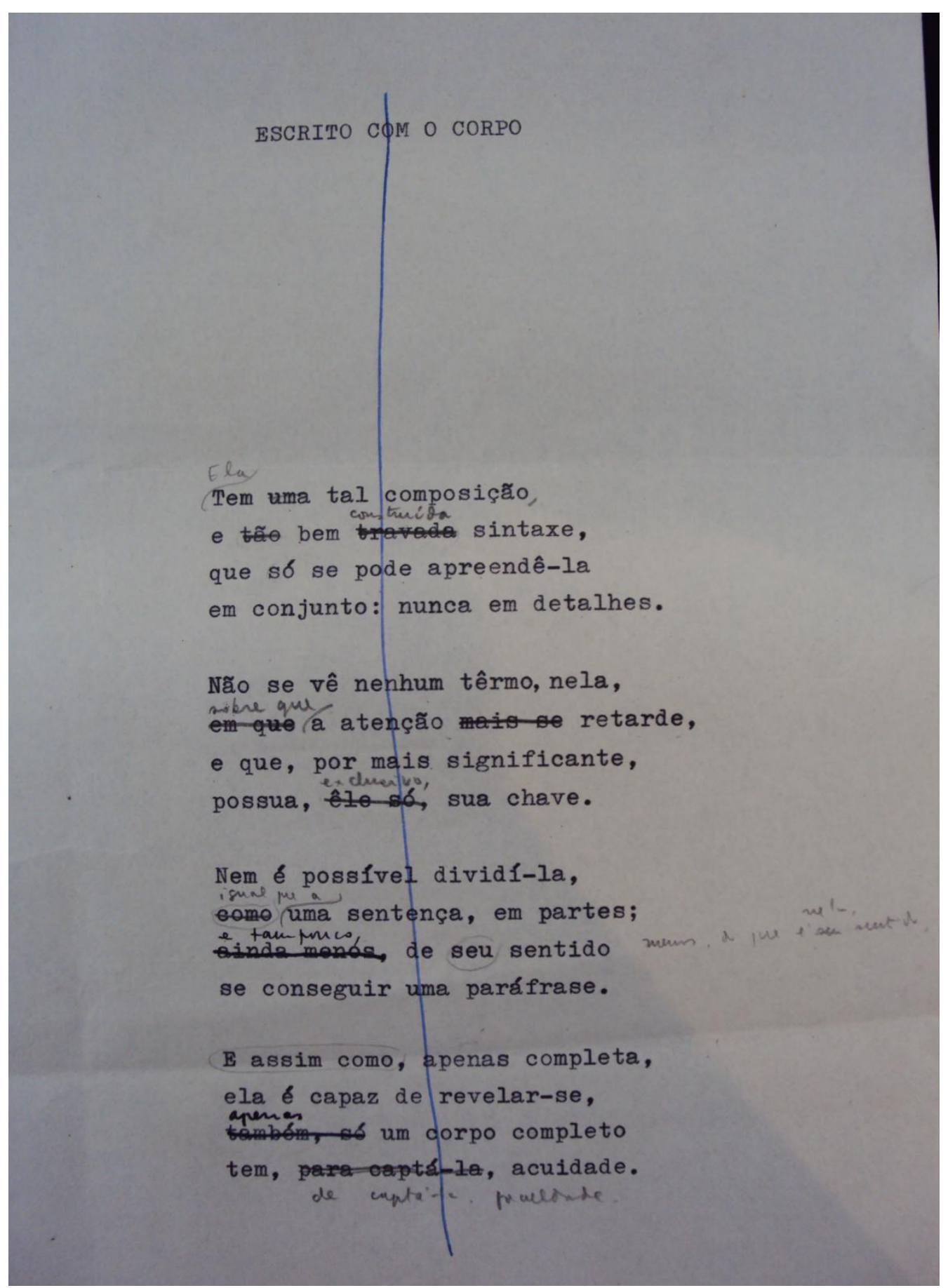

Datiloscrito reformulado da primeira parte do poema. Pasta Pi. Serial, fólio 57 recto. Arquivo literário de João Cabral de Melo Neto, Fundação Casa de Rui Barbosa. 


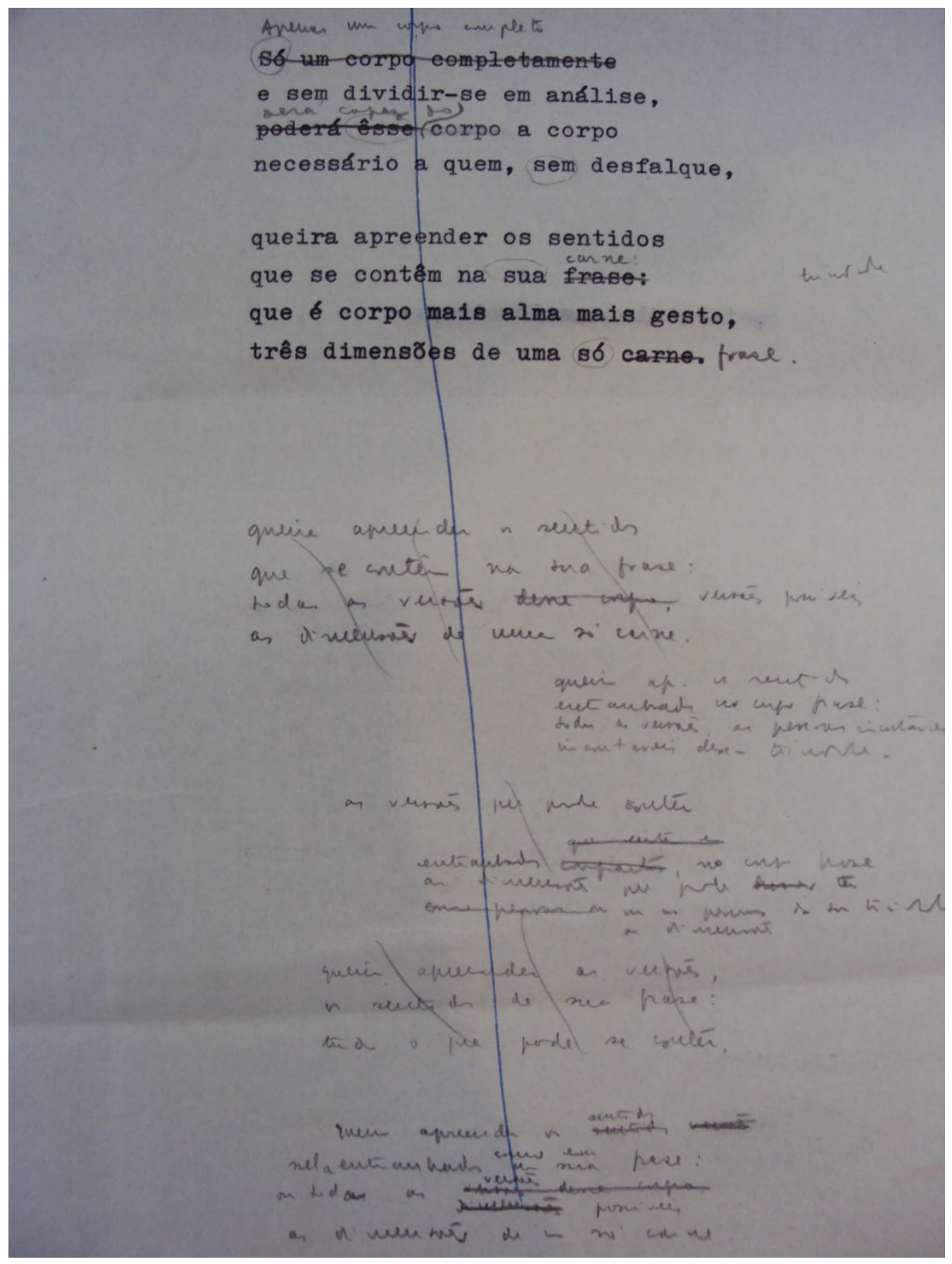

Datiloscrito reformulado da primeira parte do poema. Pasta Pi. Serial, fólio 58 recto. Arquivo literário de João Cabral de Melo Neto, Fundação Casa de Rui Barbosa. 


\section{Anexo 3: “Graciliano Ramos:”}

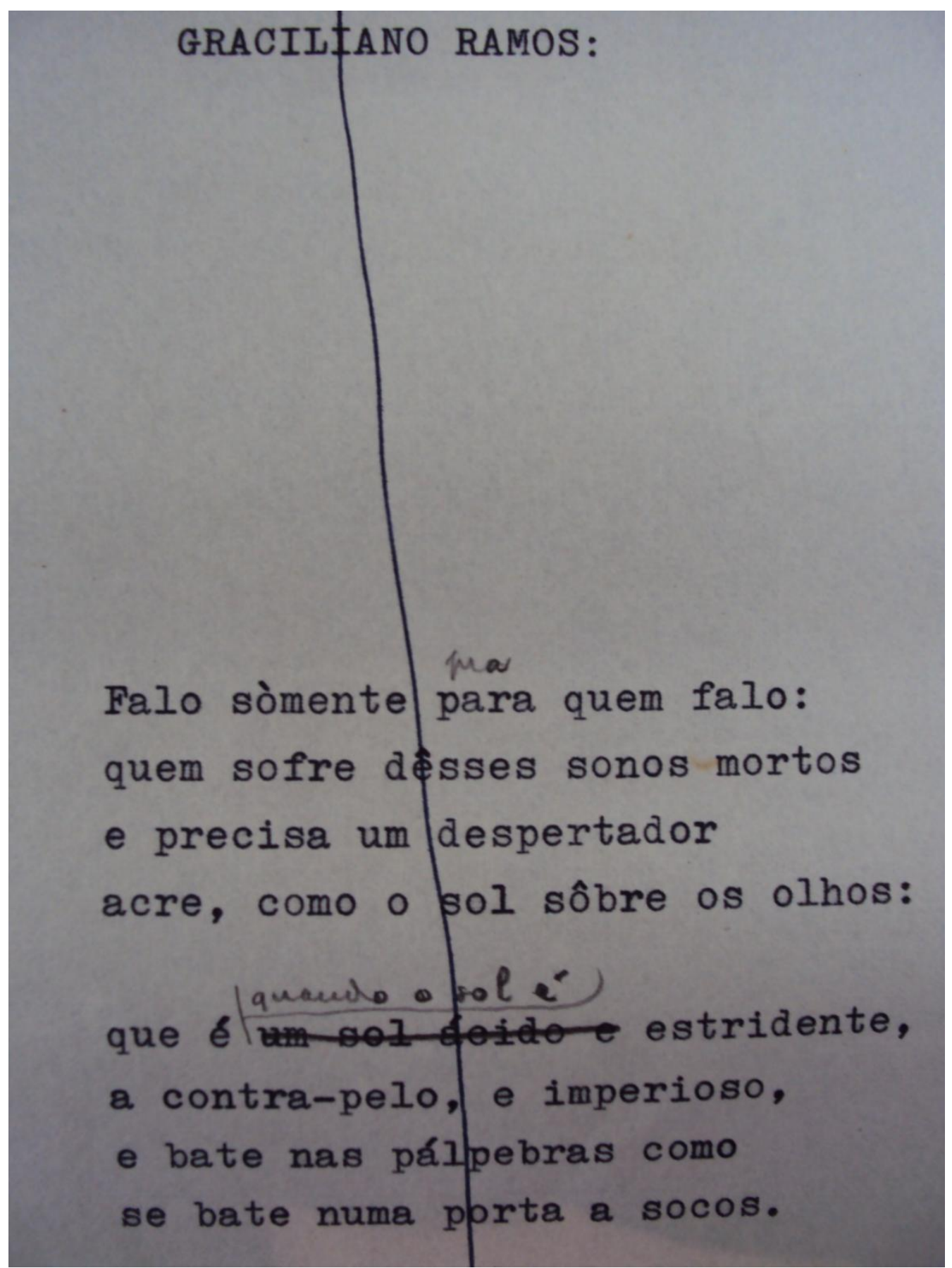

Datiloscrito reformulado da primeira parte do poema. Pasta Pi. Serial, fólio 49 recto. Arquivo literário de João Cabral de Melo Neto, Fundação Casa de Rui Barbosa. 


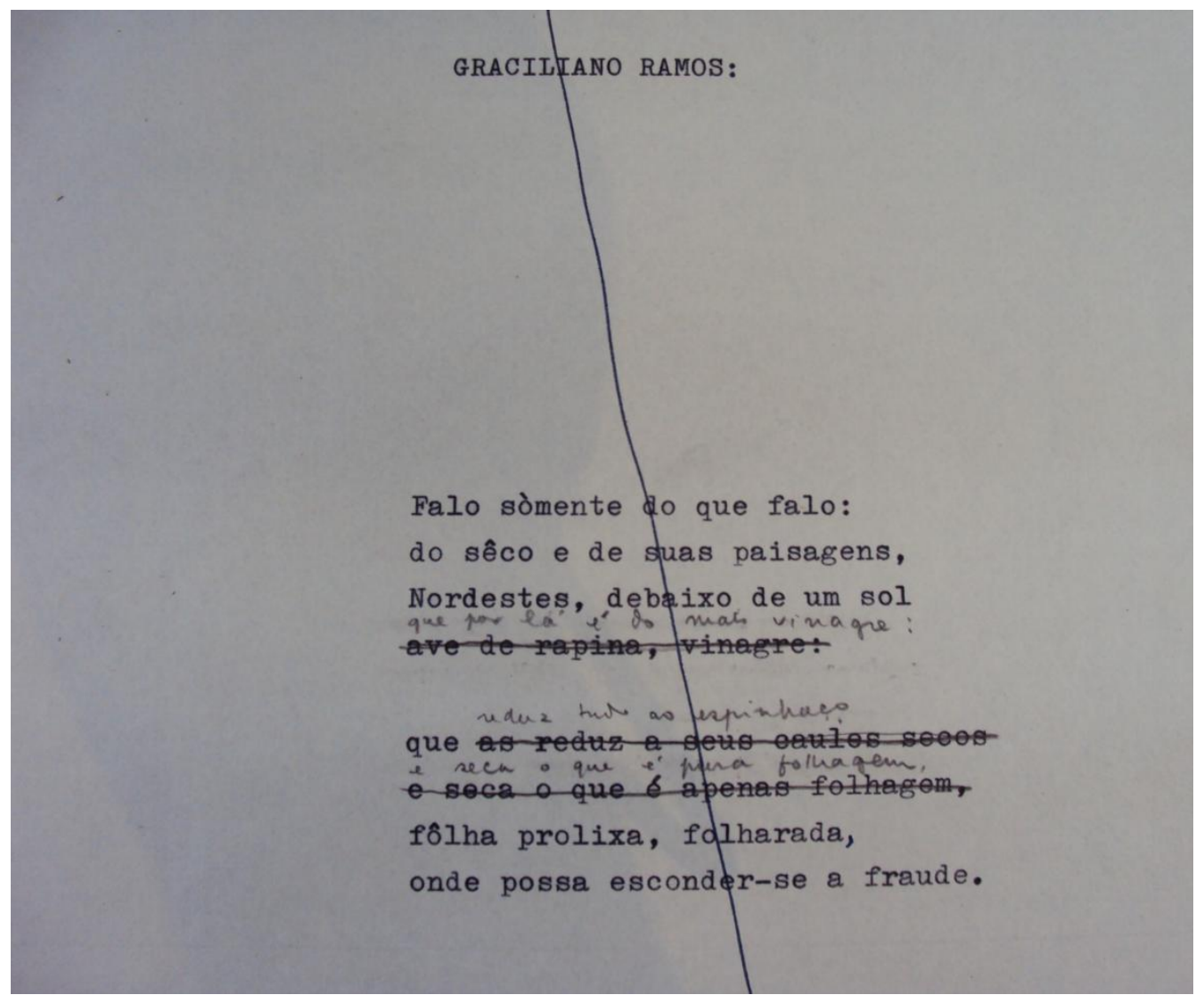

Datiloscrito reformulado da segunda parte do poema. Pasta Pi. Serial, fólio 50 recto. Arquivo literário de João Cabral de Melo Neto, Fundação Casa de Rui Barbosa. 


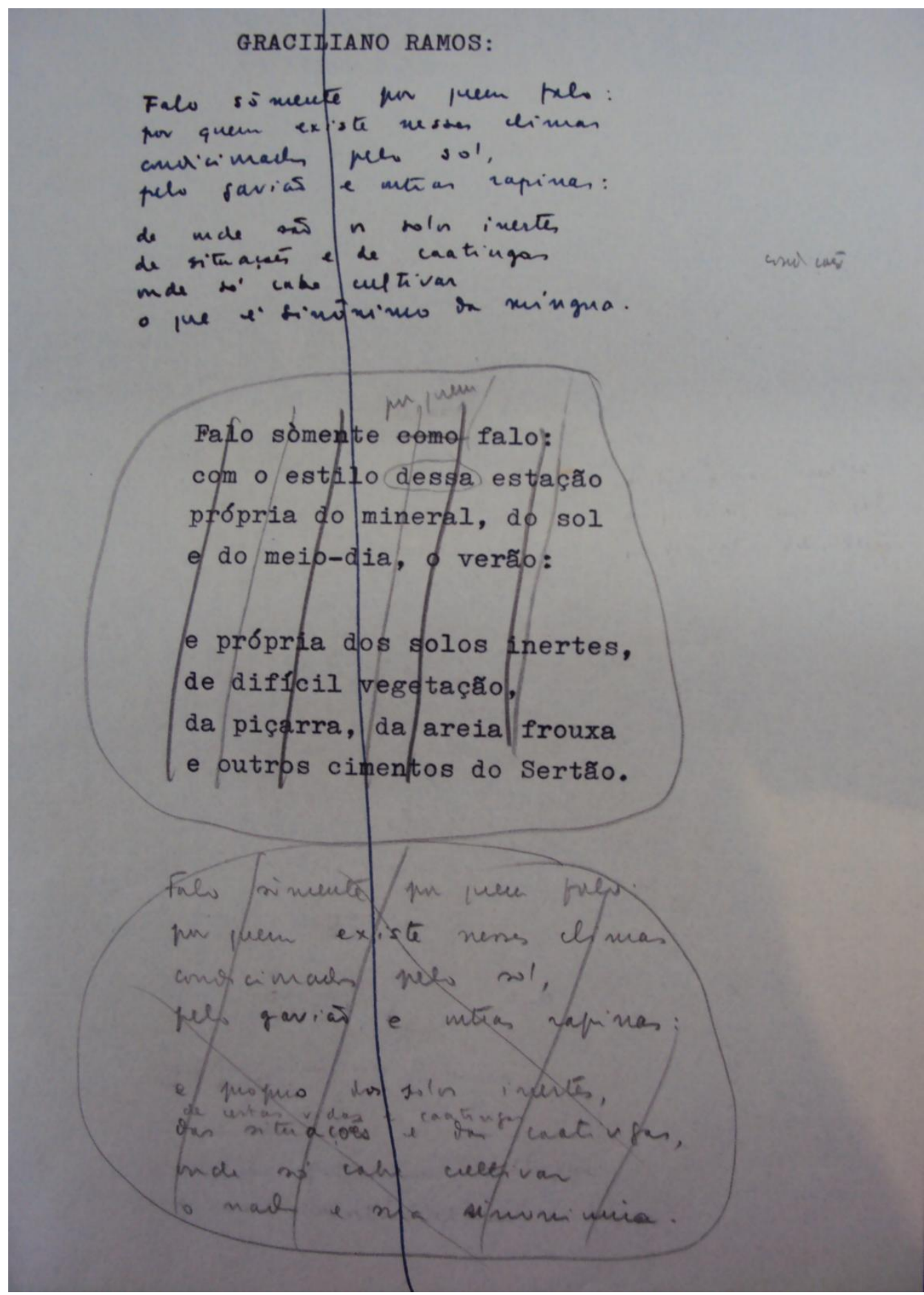

Datiloscrito reformulado da terceira parte do poema. Pasta Pi. Serial, fólio 51 recto. Arquivo literário de João Cabral de Melo Neto, Fundação Casa de Rui Barbosa. 


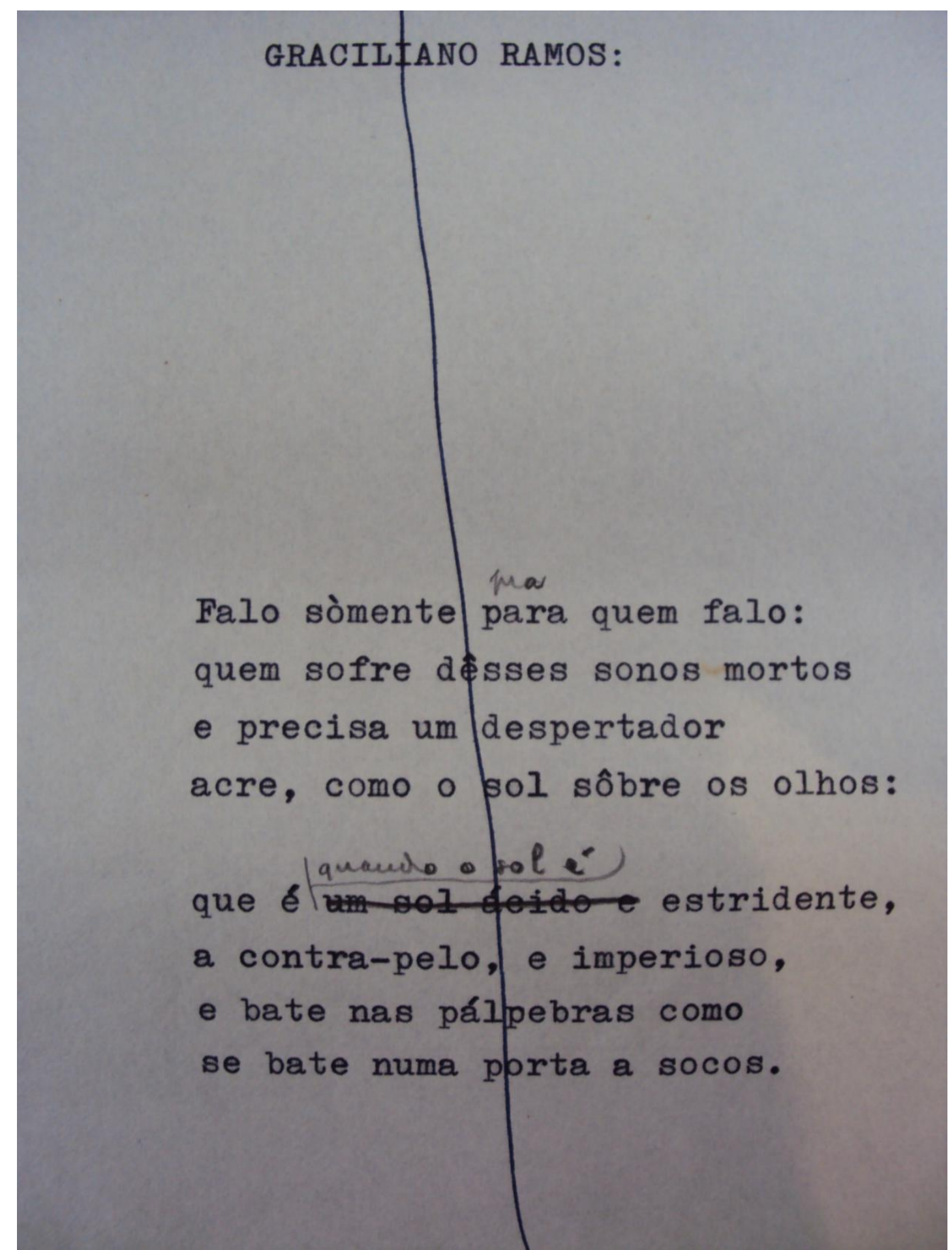

Datiloscrito reformulado da terceira parte do poema. Pasta Pi. Serial, fólio 52 recto. Arquivo literário de João Cabral de Melo Neto, Fundação Casa de Rui Barbosa. 


\section{Anexo 4. “Catar feijão"}

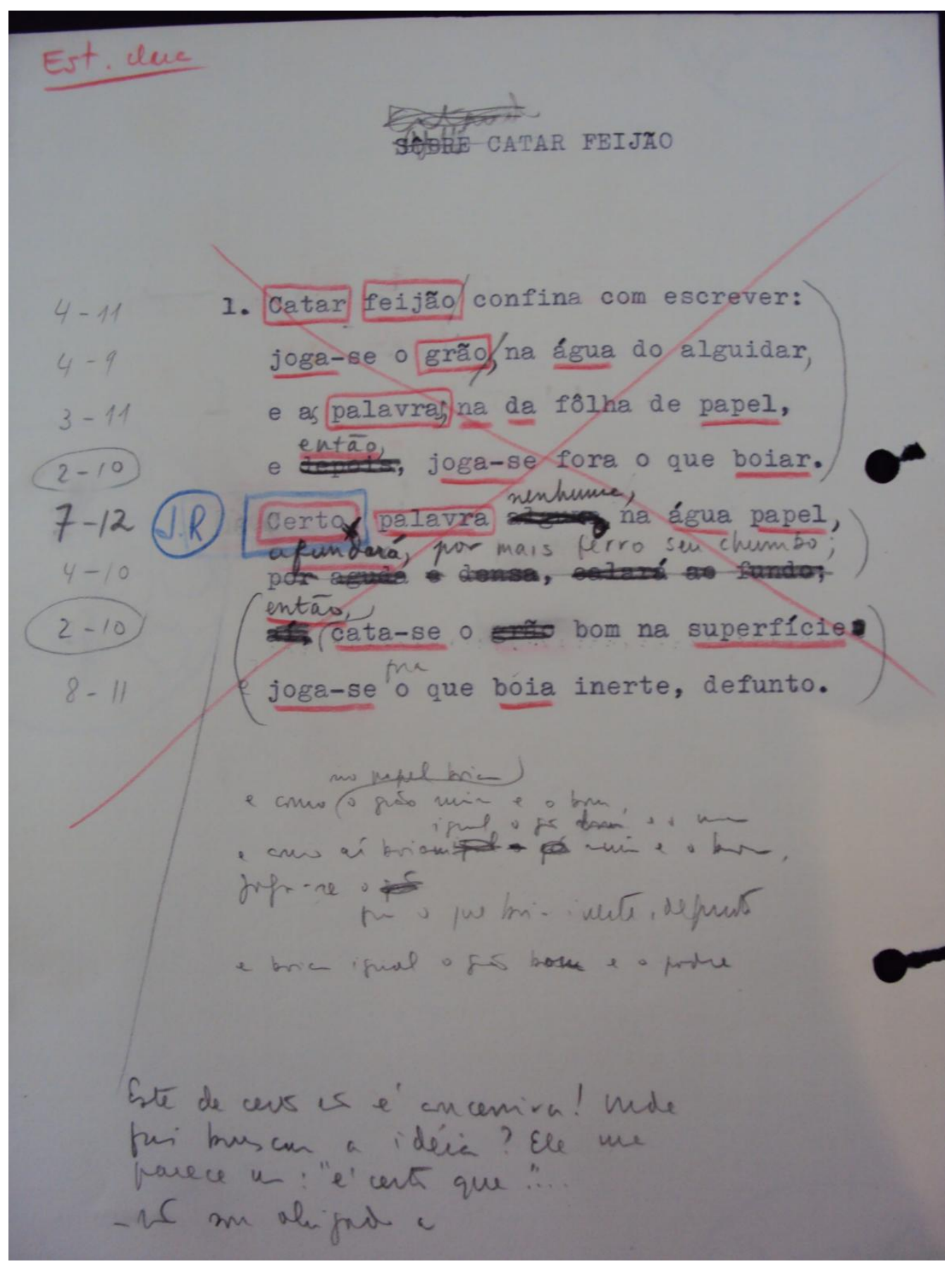

Datiloscrito reformulado do poema. Pasta Pi. A educação pela pedra 1, fólio 59 recto. Arquivo literário de João Cabral de Melo Neto, Fundação Casa de Rui Barbosa. 


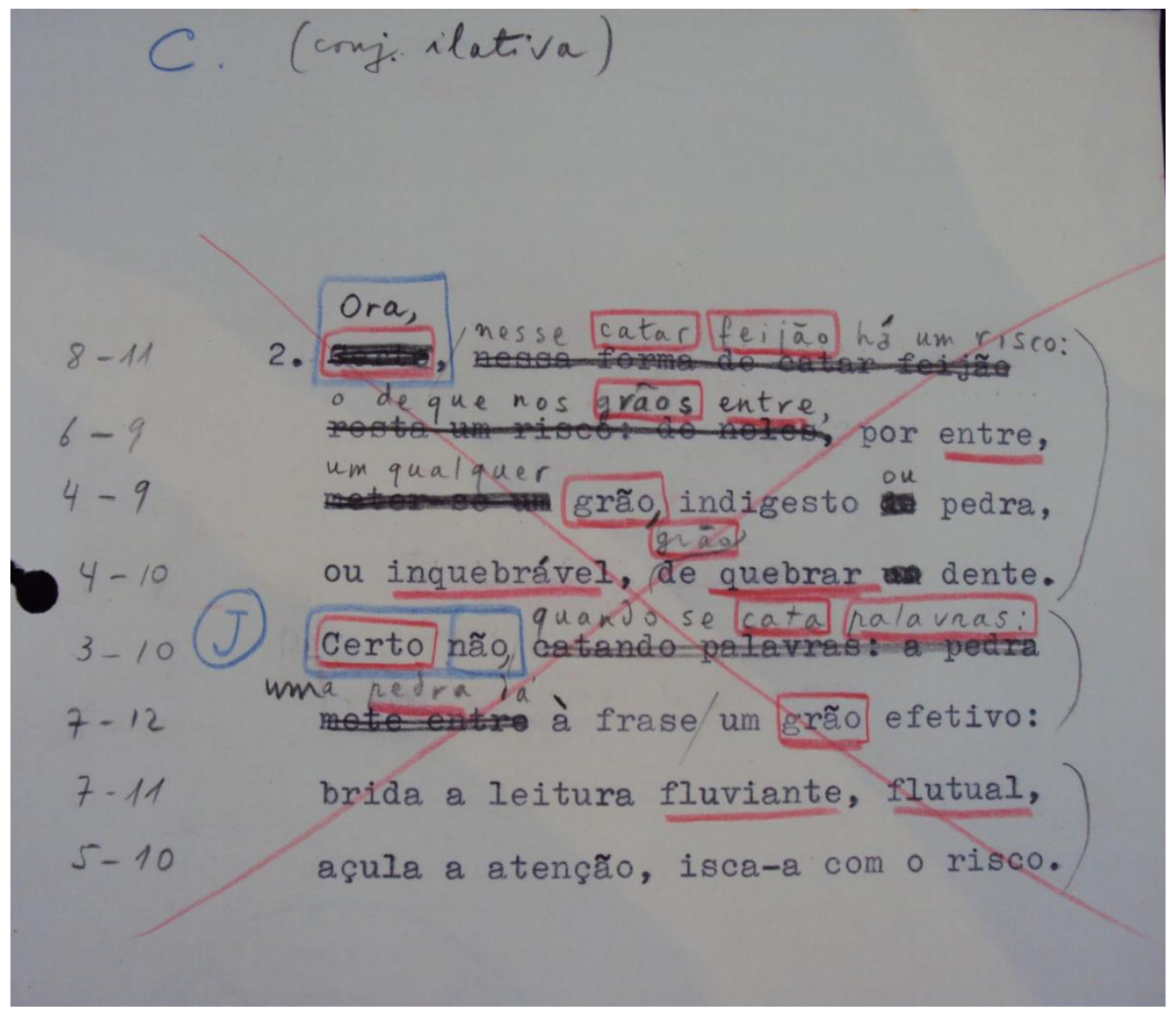

Datiloscrito reformulado do poema. Pasta Pi. A educação pela pedra 1, fólio 60 recto. Arquivo literário de João Cabral de Melo Neto, Fundação Casa de Rui Barbosa. 


\section{Anexo 5: "Bifurcados de 'Habitar o tempo"}

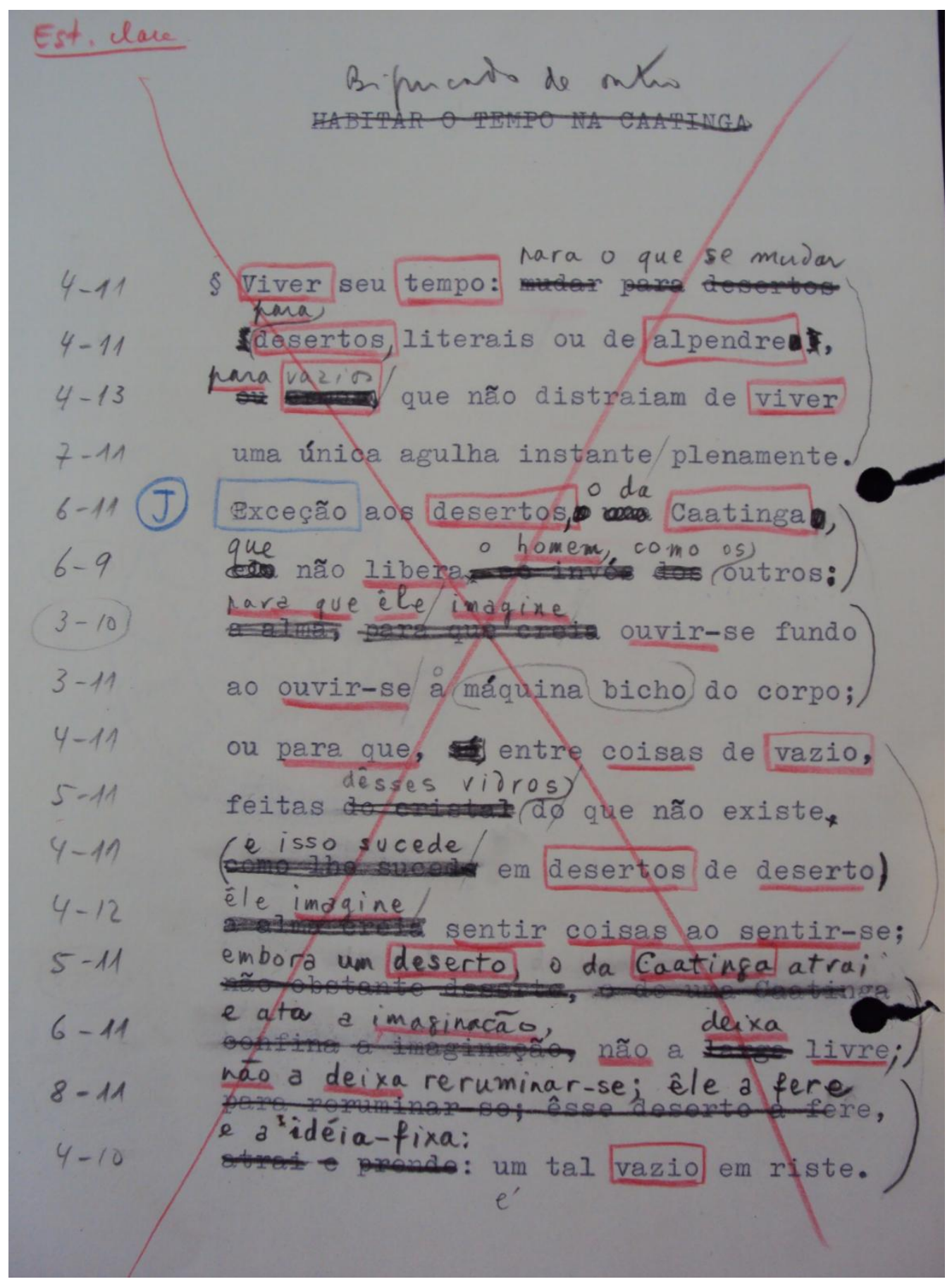

Datiloscrito reformulado do poema. Pasta Pi. A educação pela pedra 1, fólio 47 recto. Arquivo literário de João Cabral de Melo Neto, Fundação Casa de Rui Barbosa. 


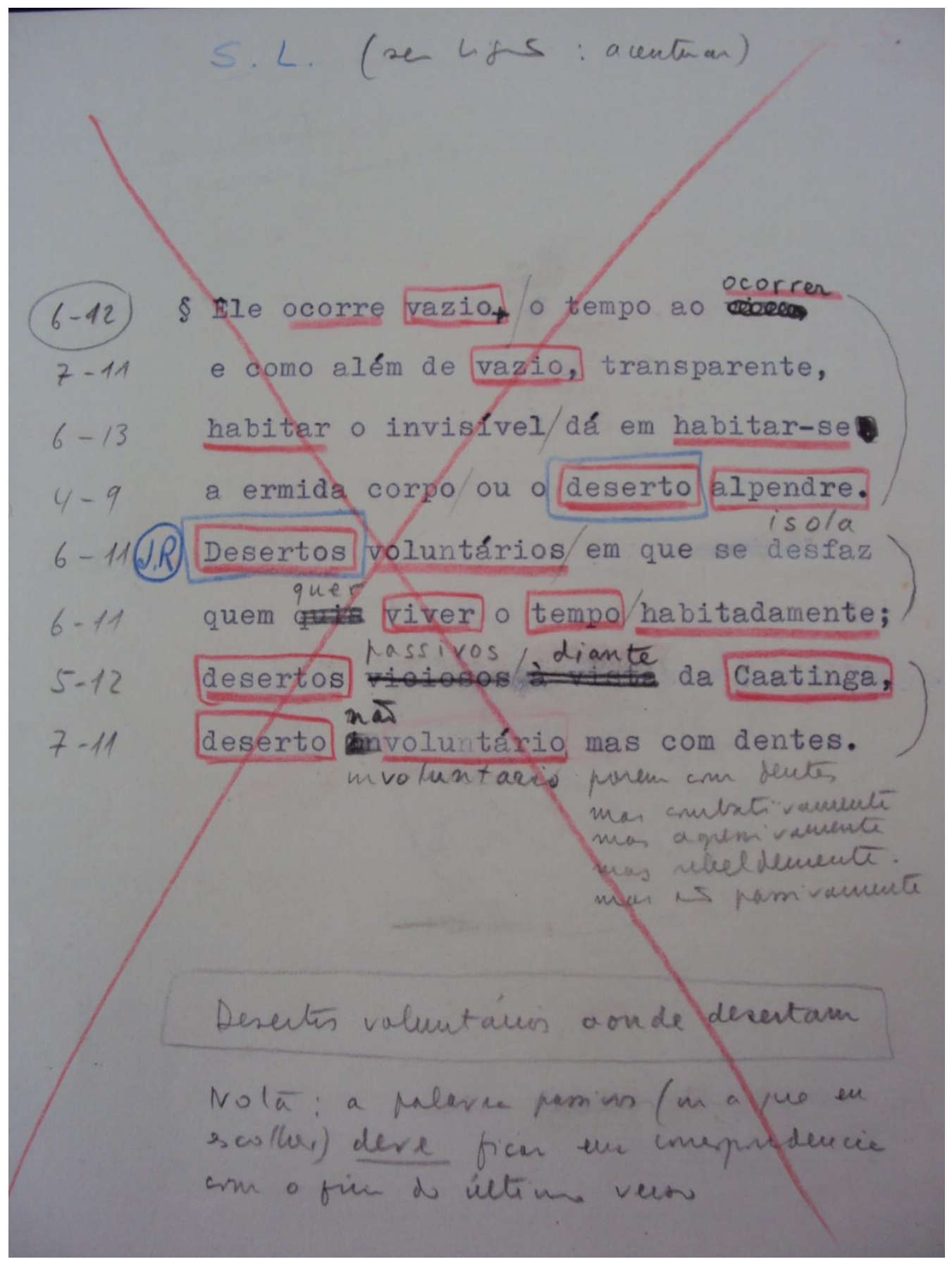

Datiloscrito reformulado do poema. Pasta Pi. A educação pela pedra 1, fólio 48 recto. Arquivo literário de João Cabral de Melo Neto, Fundação Casa de Rui Barbosa. 


\section{Anexo 6: "Habitar o tempo"}

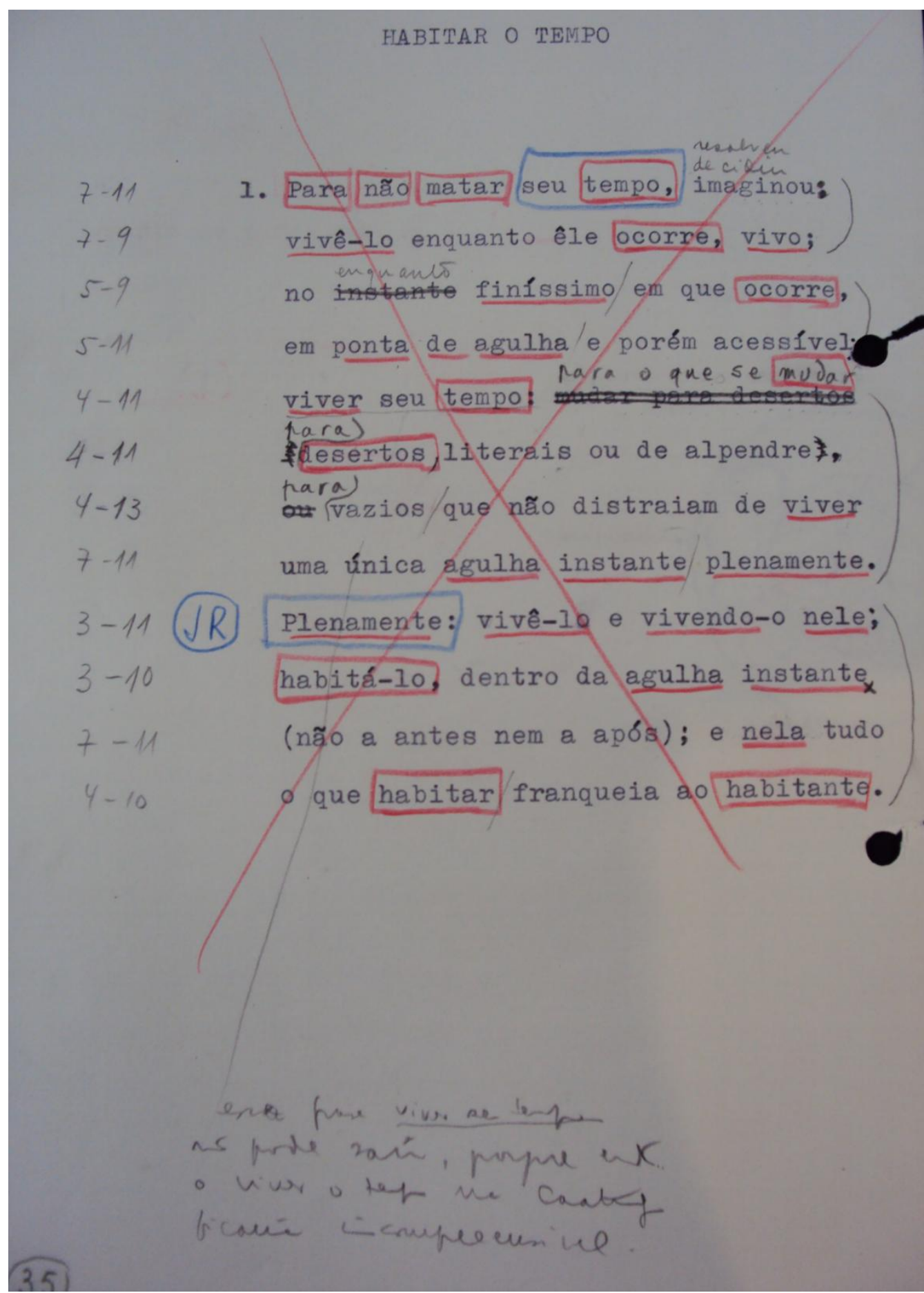

Datiloscrito reformulado do poema. Pasta Pi. A educação pela pedra 1, fólio 35 recto. Arquivo literário de João Cabral de Melo Neto, Fundação Casa de Rui Barbosa. 


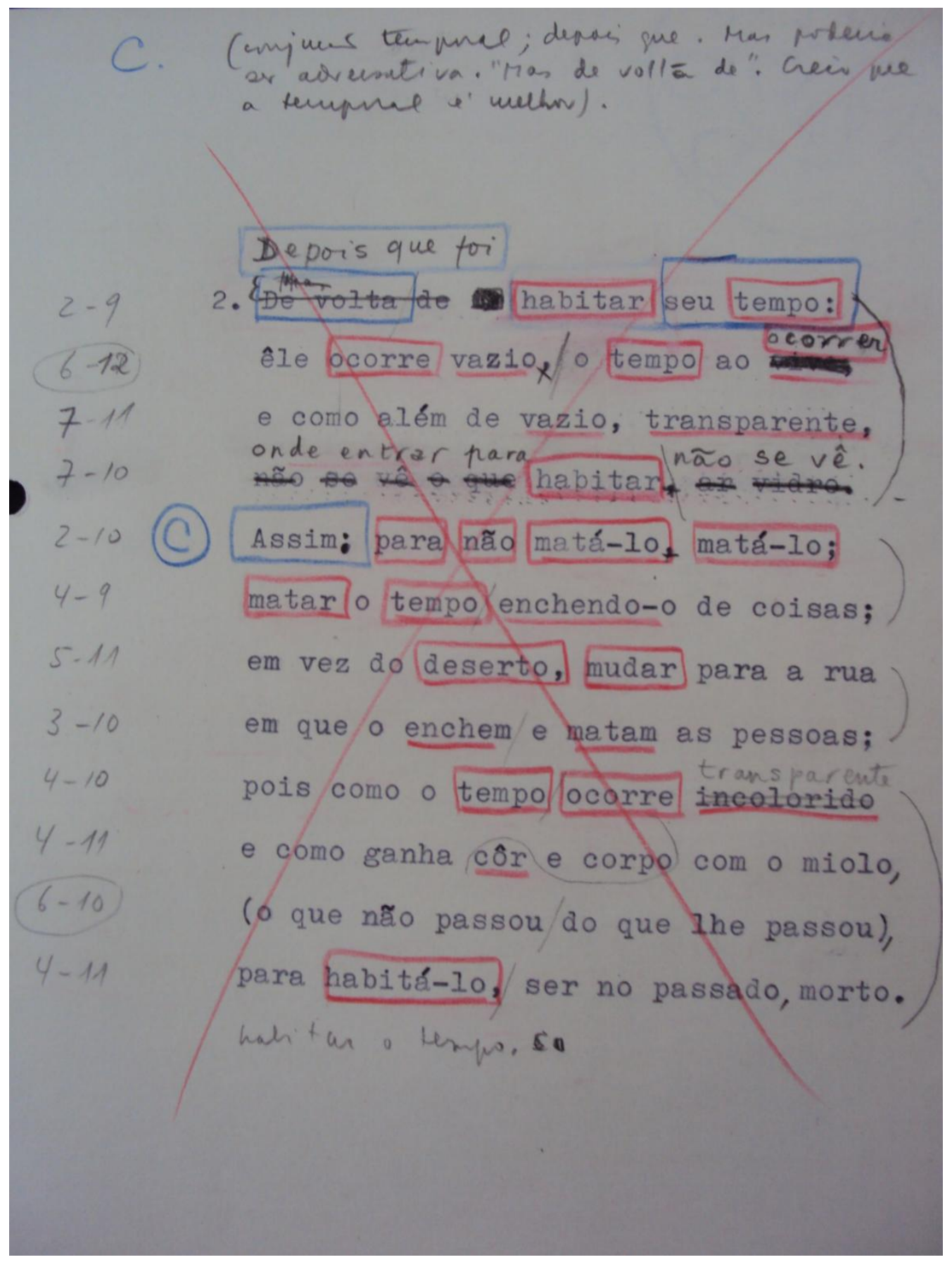

Datiloscrito reformulado do poema Pasta Pi. A educação pela pedra 1, fólio 36 recto. Arquivo literário de João Cabral de Melo Neto, Fundação Casa de Rui Barbosa. 


\section{Anexo 7: "Na morte dos rios"}

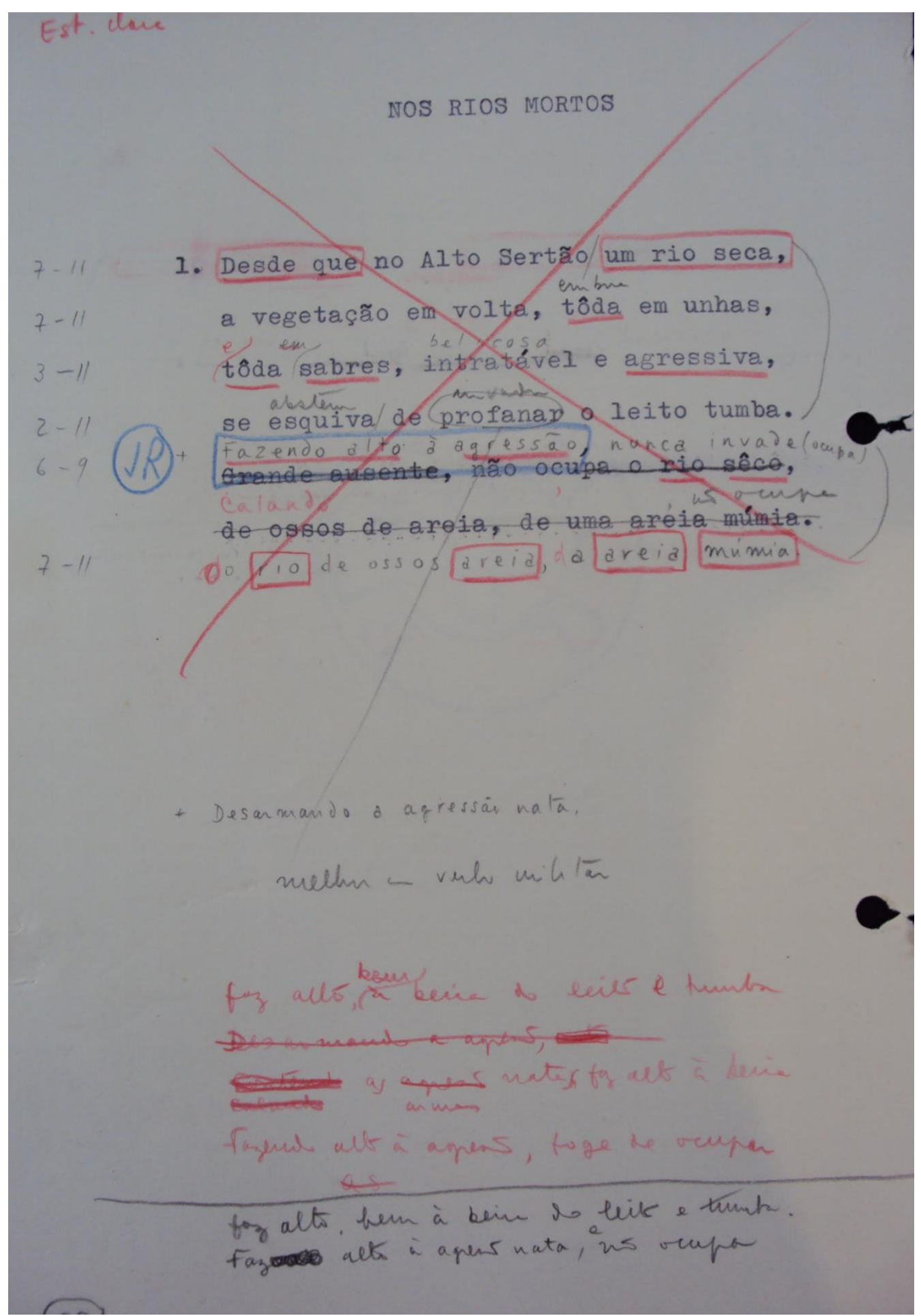

Datiloscrito reformulado do poema. Pasta Pi. A educação pela pedra 1, fólio 89 recto. Arquivo literário de João Cabral de Melo Neto, Fundação Casa de Rui Barbosa. 


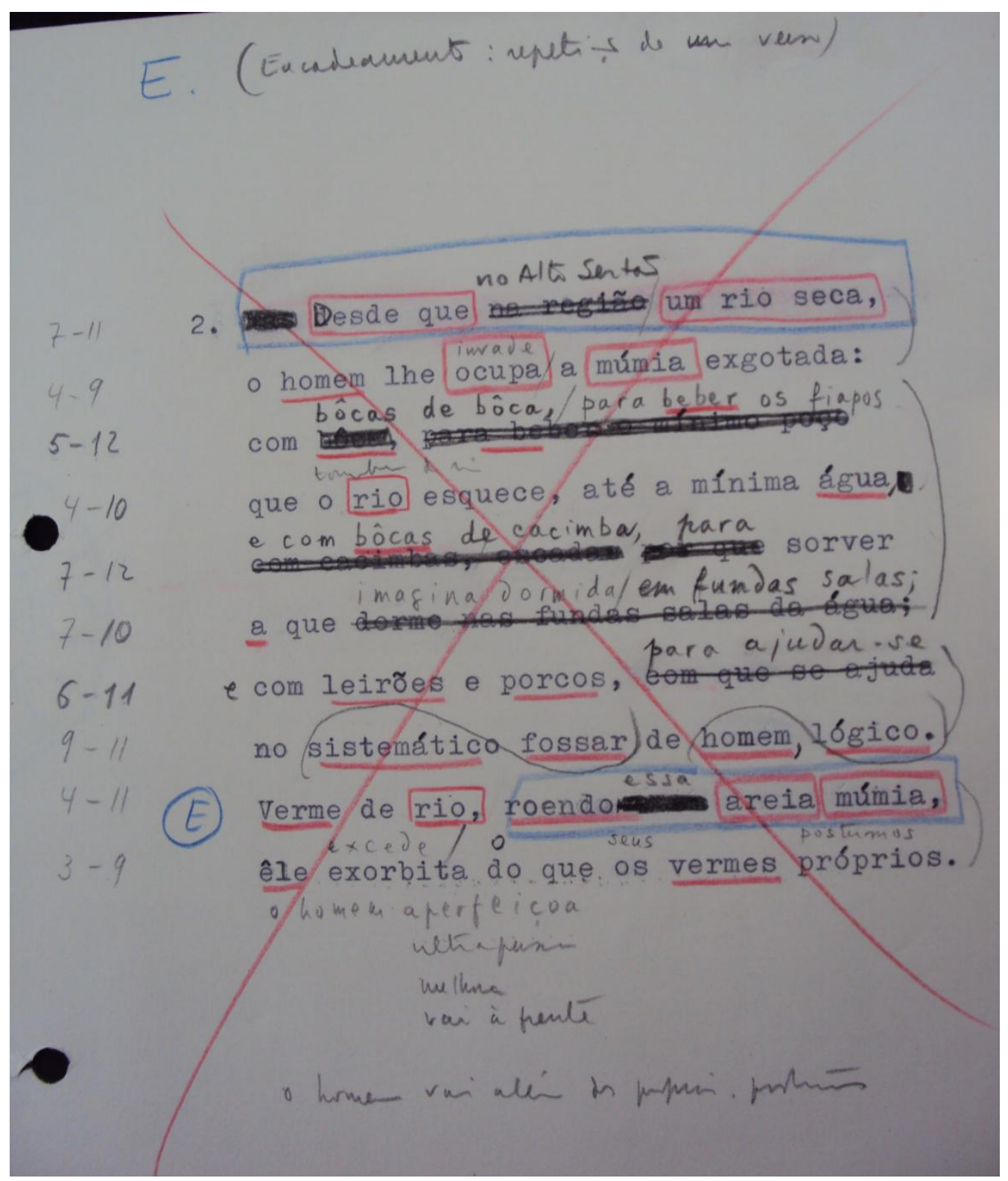

Datiloscrito reformulado do poema. Pasta Pi. A educação pela pedra 1, fólio 90 recto. Arquivo literário de João Cabral de Melo Neto, Fundação Casa de Rui Barbosa. 


\section{Anexo 8: "Para a feira do livro"}

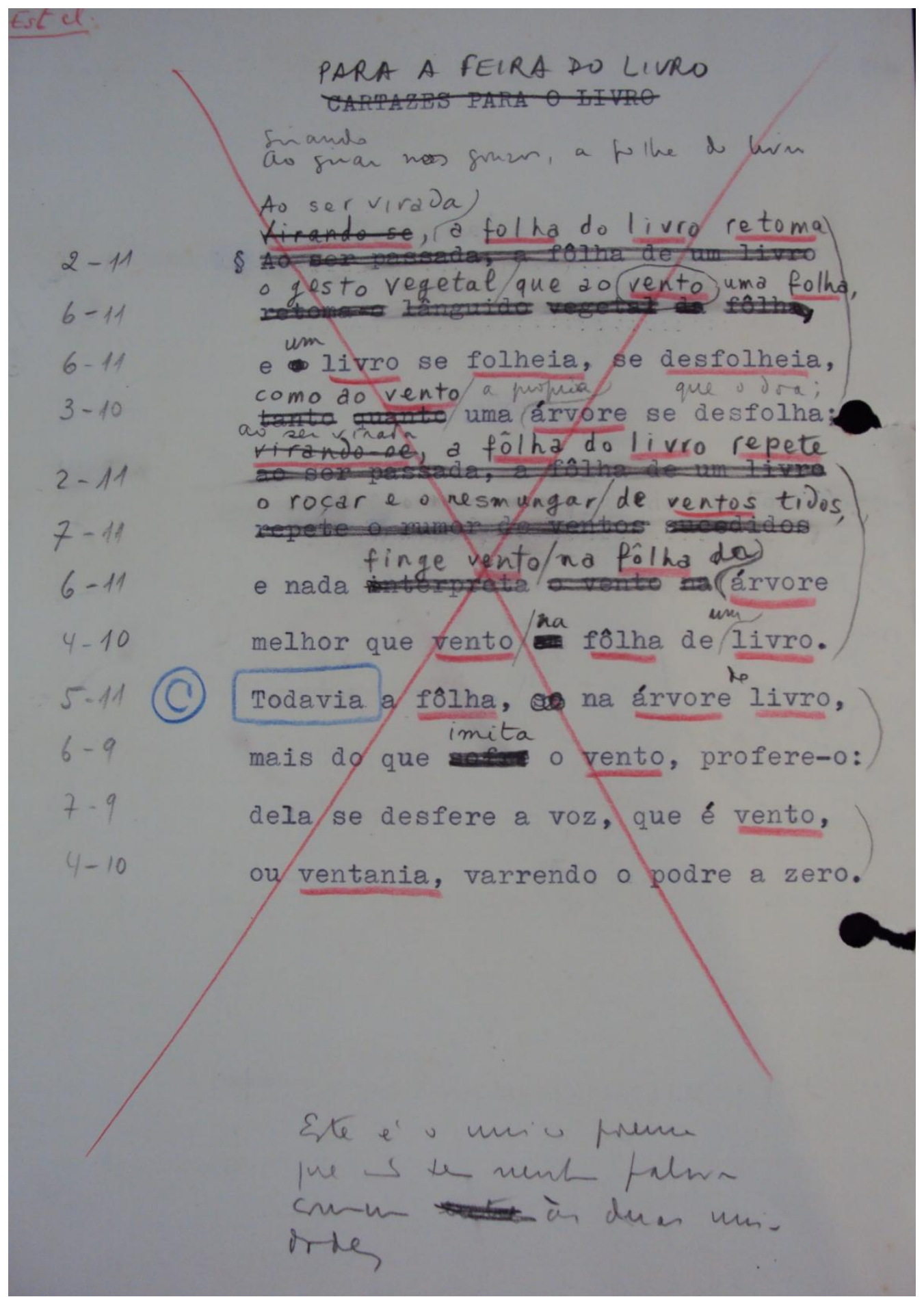

Datiloscrito reformulado do poema. Pasta Pi. A educação pela pedra 1, fólio 3 recto. Arquivo literário de João Cabral de Melo Neto, Fundação Casa de Rui Barbosa. 


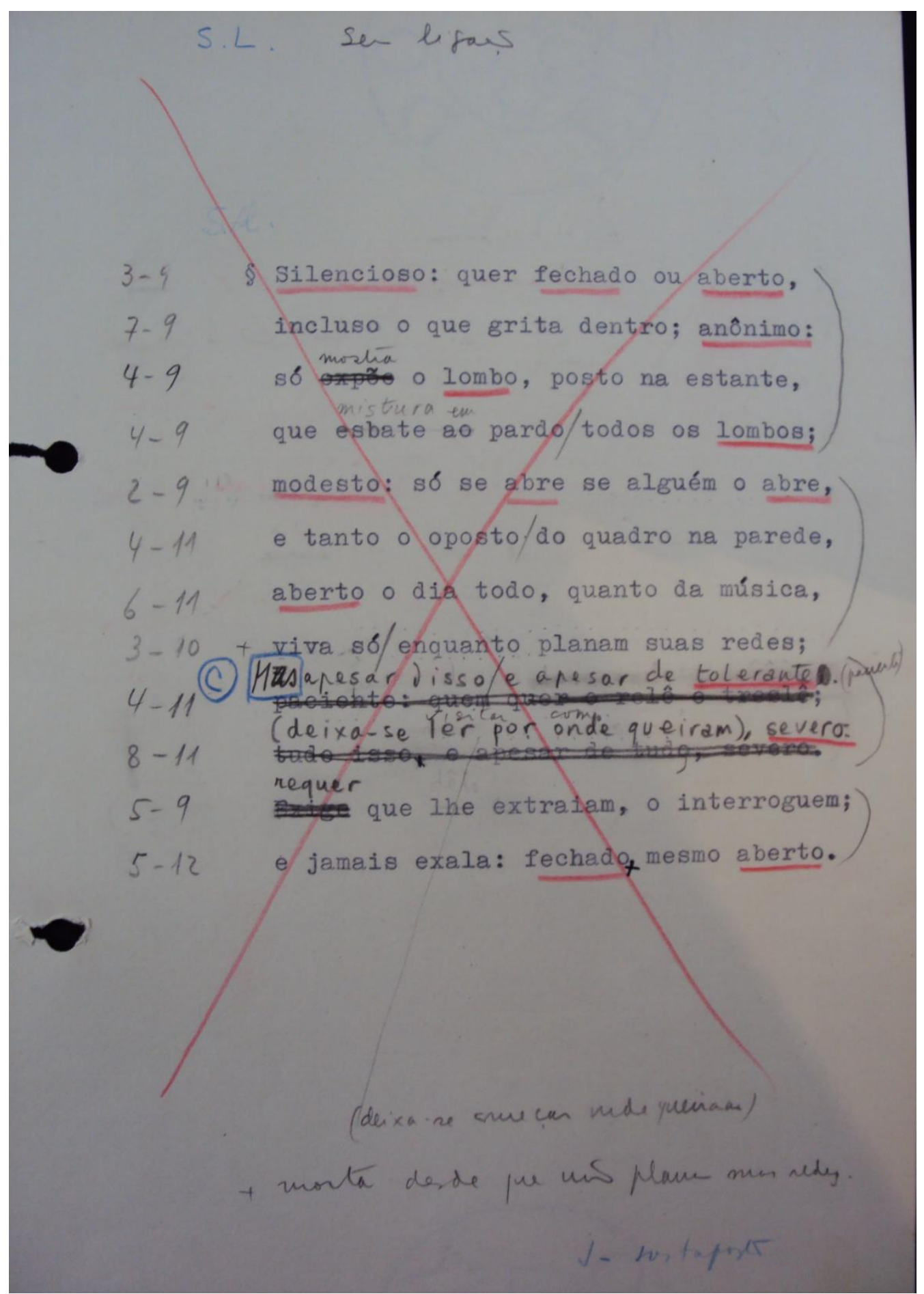

Datiloscrito reformulado do poema. Pasta Pi. A educação pela pedra 1, fólio 4 recto. Arquivo literário de João Cabral de Melo Neto, Fundação Casa de Rui Barbosa. 


\section{Anexo 9: "Planta baixa" de $A$ educação pela pedra}

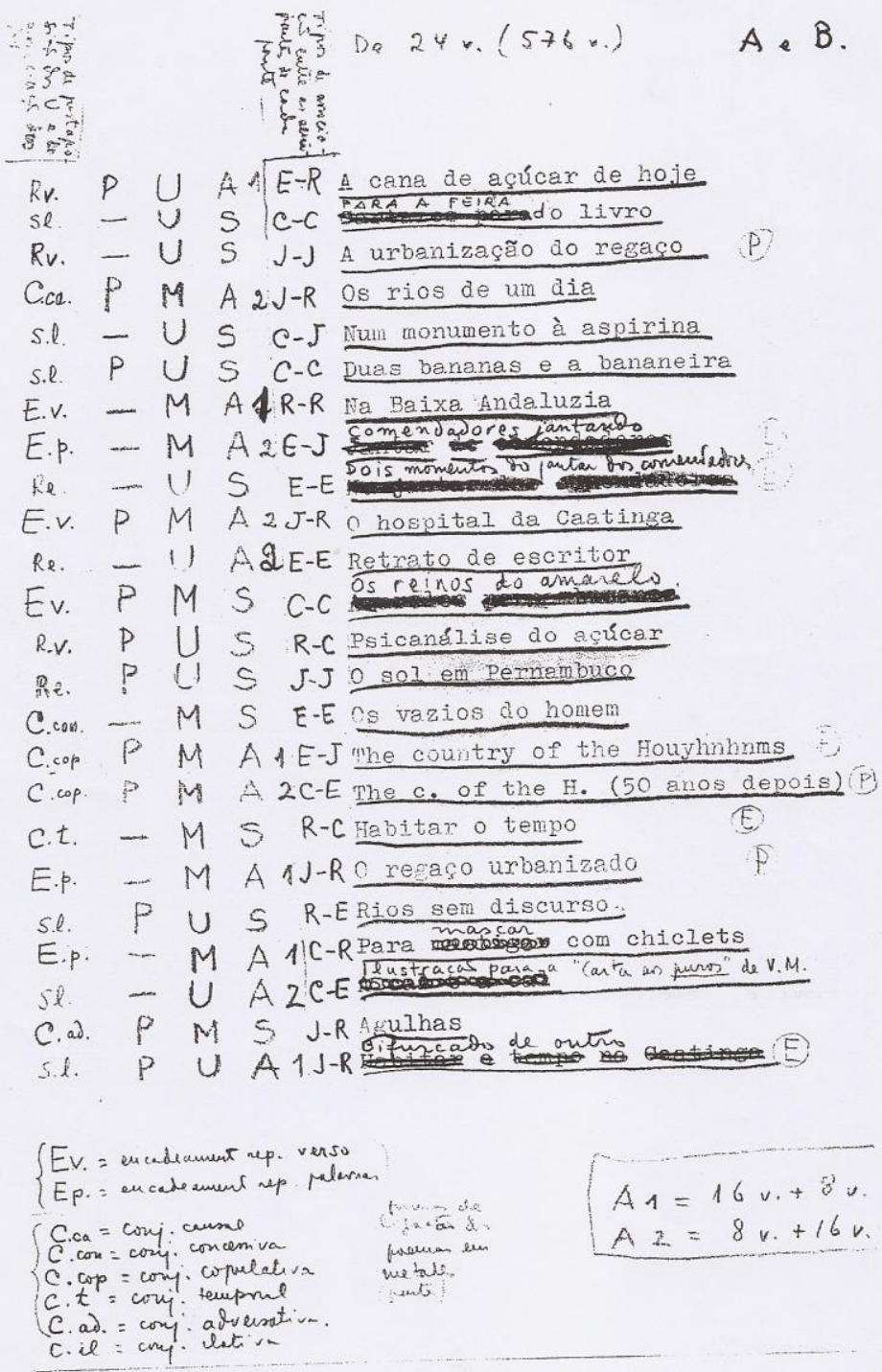

Publicado por Antonio Carlos Secchin na revista Colóquio-Letras. Paisagem tipográfica. Homenagem a João Cabral de Melo Neto (1920 - 1990), $2000, n^{\circ}$ s $157 / 158$. 

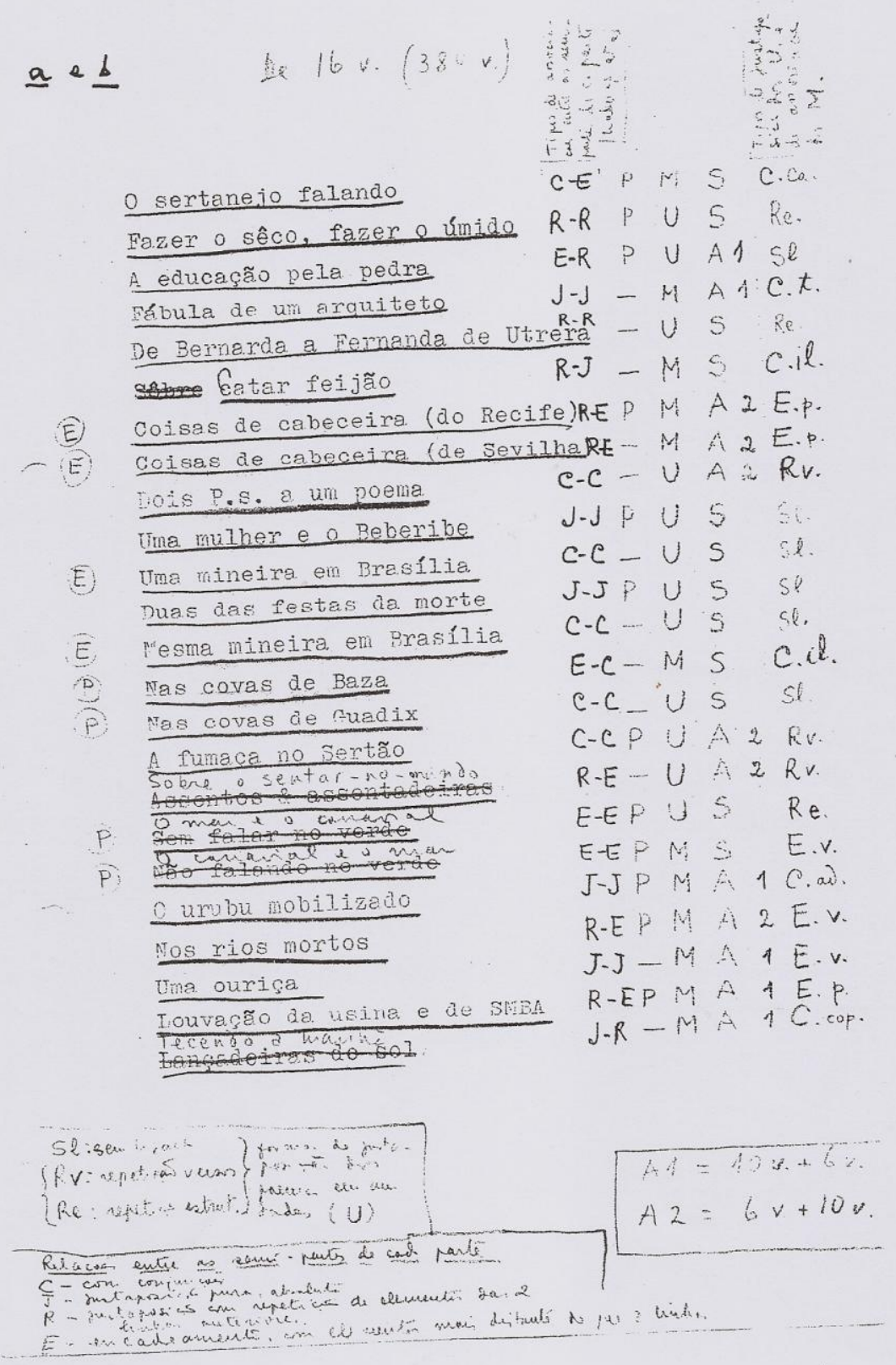

Publicado por Antonio Carlos Secchin na revista Colóquio-Letras.

Paisagem tipográfica. Homenagem a João Cabral de Melo Neto (1920 - 1990), $2000, n^{\circ}$ s $157 / 158$. 


\section{Anexo 10: "Prosas da maré na Jaqueira"}

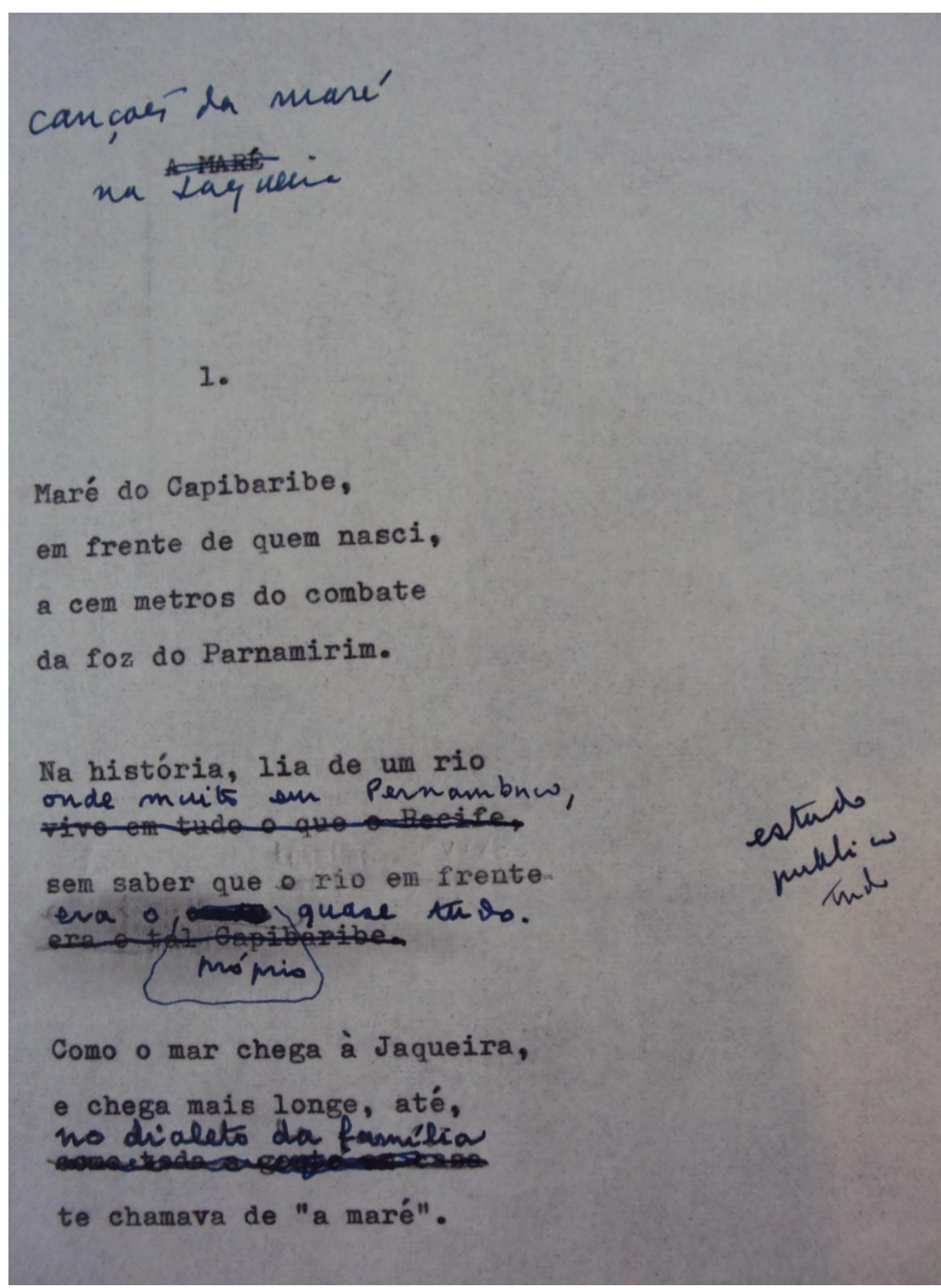

Datiloscrito reformulado da primeira parte do poema. Pasta Pi. Poemas pernambucanos, fólio 19 recto. Arquivo literário de João Cabral de Melo Neto, Fundação Casa de Rui Barbosa. 


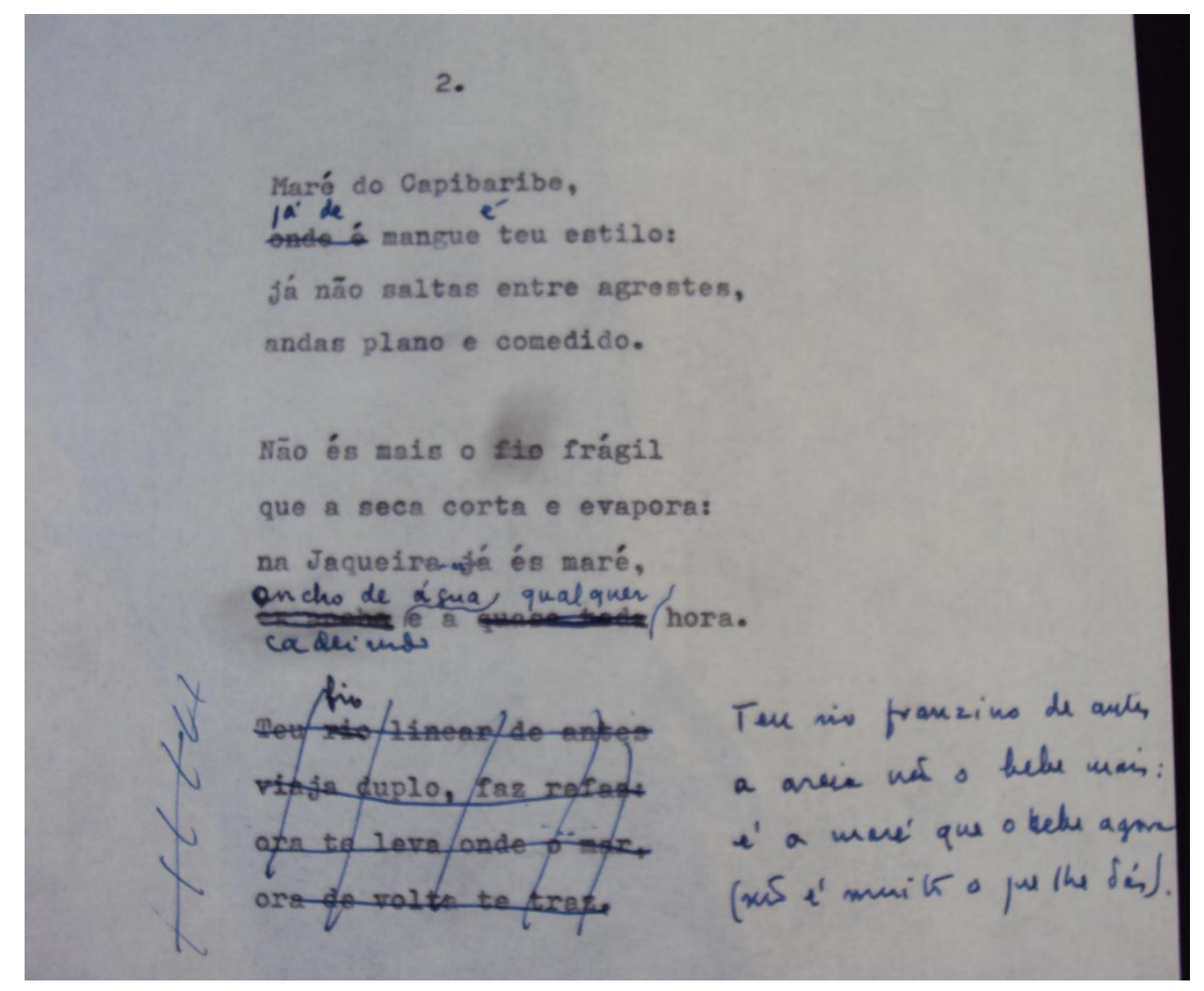

Anexo 10: datiloscrito reformulado da segunda parte do poema. Pasta Pi. Poemas pernambucanos, fólio 20 recto. Arquivo literário de João Cabral de Melo Neto, Fundação Casa de Rui Barbosa. 


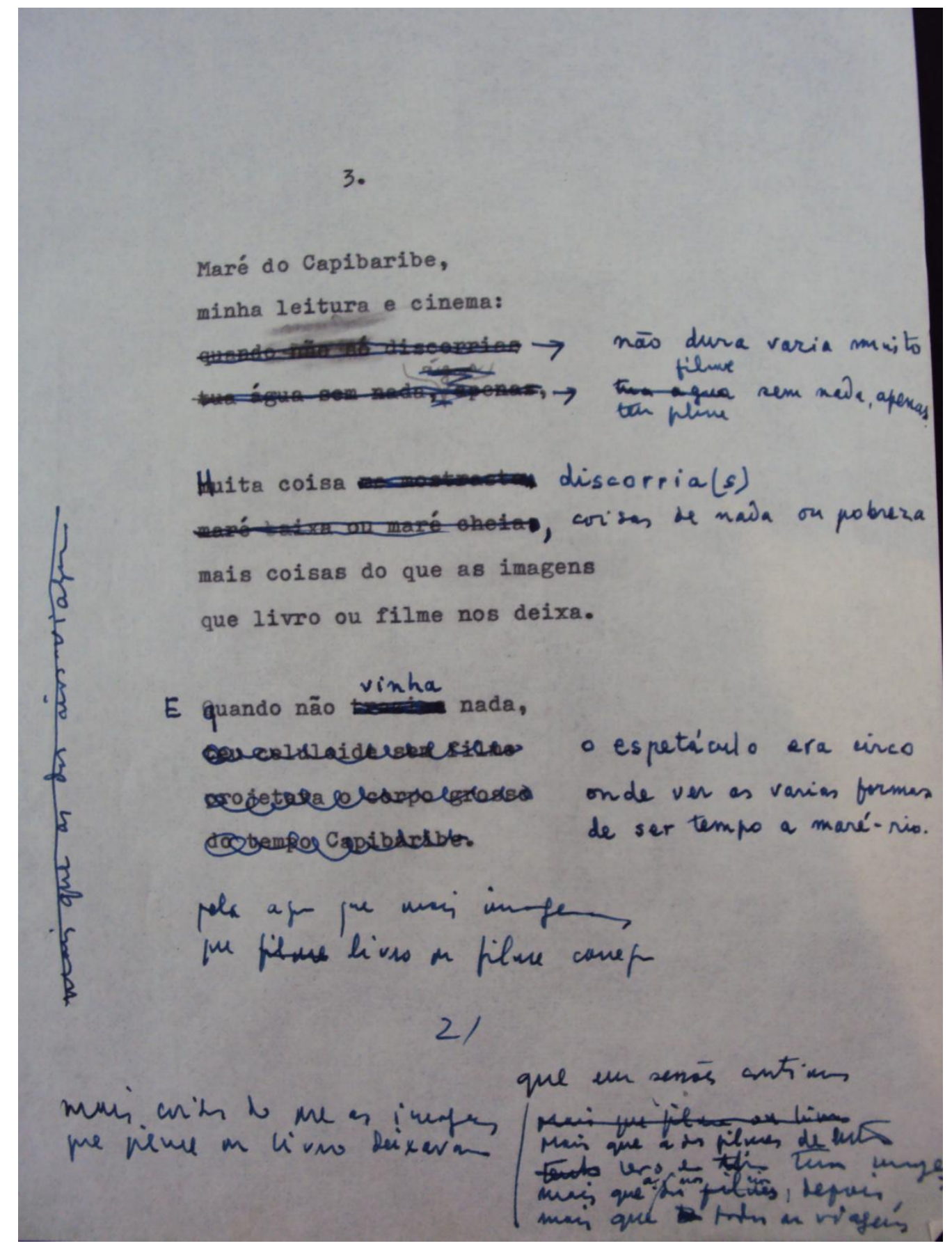

Datiloscrito reformulado da terceira parte do poema. Pasta Pi. Poemas pernambucanos, fólio 21 recto. Arquivo literário de João Cabral de Melo Neto, Fundação Casa de Rui Barbosa. 


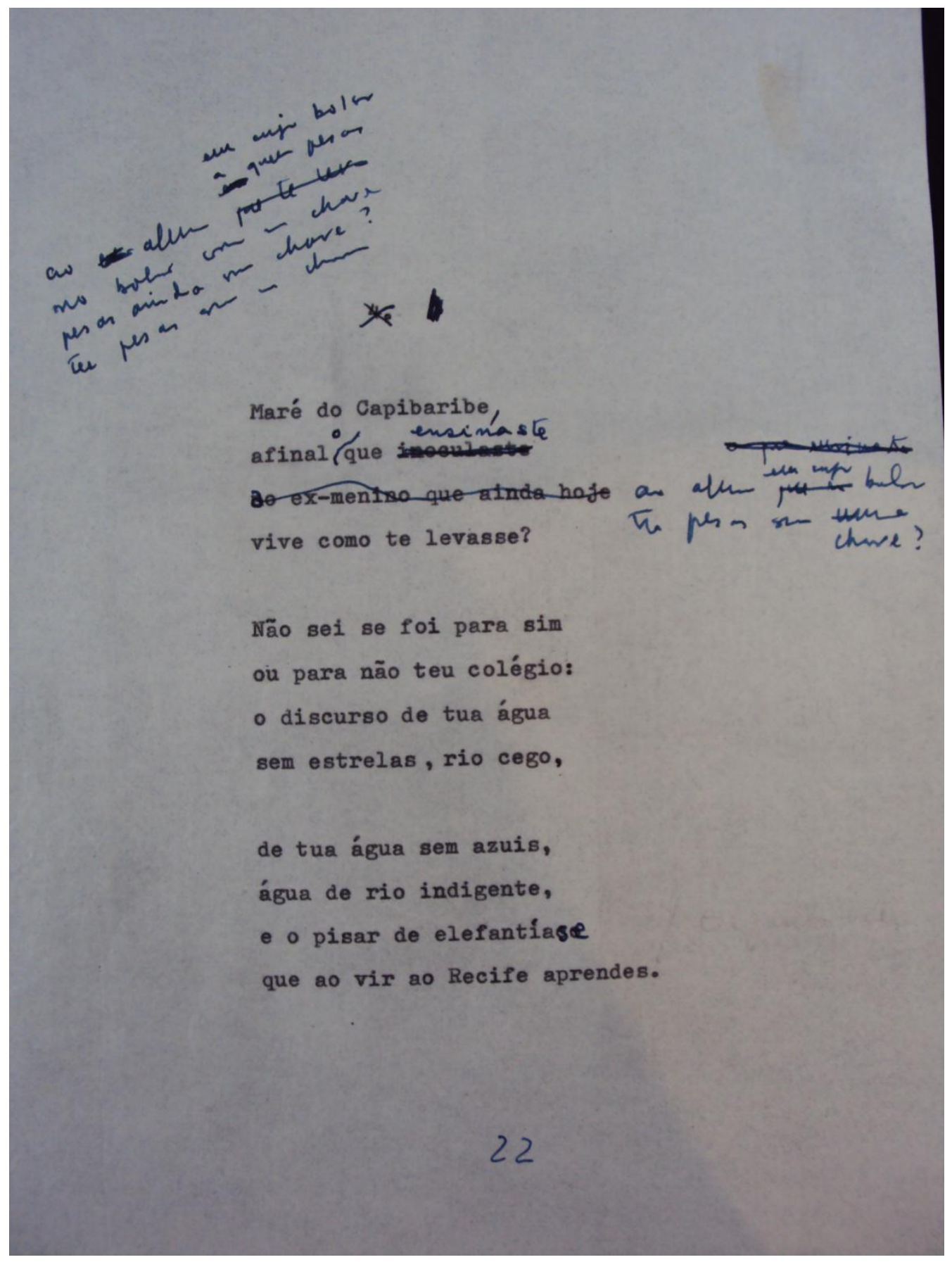

Datiloscrito reformulado da quarta parte do poema. Pasta Pi. Poemas pernambucanos, fólio 22 recto. Arquivo literário de João Cabral de Melo Neto, Fundação Casa de Rui Barbosa. 


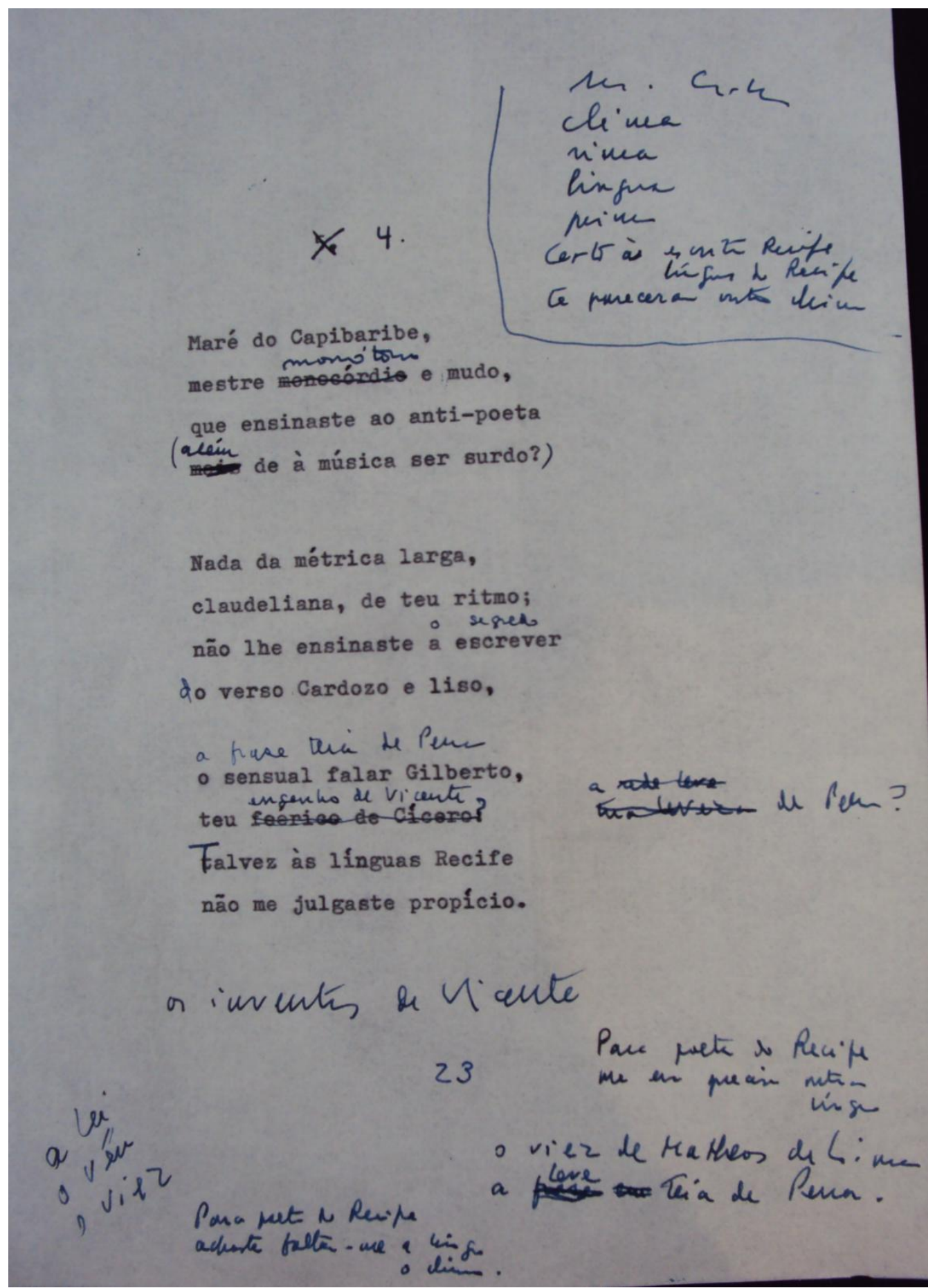

Datiloscrito reformulado da quinta parte do poema. Pasta Pi. Poemas pernambucanos, fólio 23 recto. Arquivo literário de João Cabral de Melo Neto, Fundação Casa de Rui Barbosa. 


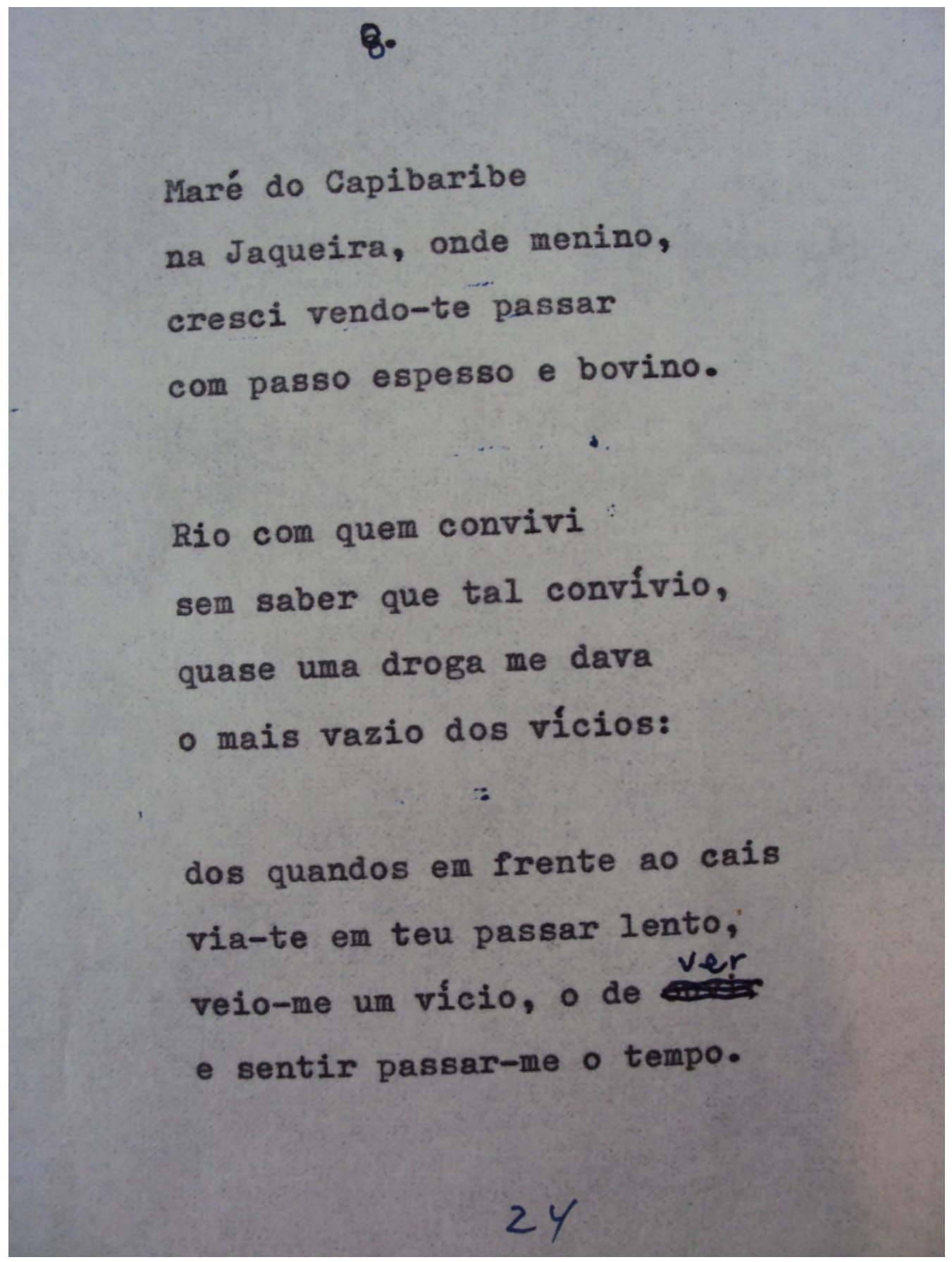

Datiloscrito reformulado da oitava parte do poema. Pasta Pi. Poemas pernambucanos, fólio 24 recto. Arquivo literário de João Cabral de Melo Neto, Fundação Casa de Rui Barbosa. 


\section{*6 6}

Maré do Capibaribe

entre a Jaqueira e Santana:

há momentos que a maré,

seu ir e vir, te empantana.

teu tempo é espaço:

en tua água de sax grosso de aur w lor

í utmuecin

arene morta, dormida,

paralítica, de poço.

$E$ H' nun c heos inthí

Teu tempo é somente espaço,

que a lasic or

us ragoa que se finge,

(oil-nada do fluir duplo

Lque enche e esvazia o Recife.

\section{$2 \sqrt{ }$}

Datiloscrito reformulado da sexta parte do poema. Pasta Pi. Poemas pernambucanos, fólio 25 recto. Arquivo literário de João Cabral de Melo Neto, Fundação Casa de Rui Barbosa. 


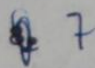

\section{Maré do Capibaribe,}

estaria a lição nisso,

em se mostrar como espaço

nos quandos em equilíbrio?

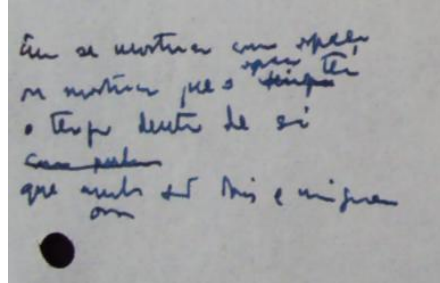

(Quandos em que tempo e espaço,

em que às vezes te deténs,

se confundem nesse enquanto

em que tu não vás nem vens).

Querias deter o tempo

no lafgo morto que imitas?

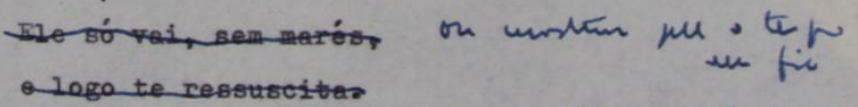

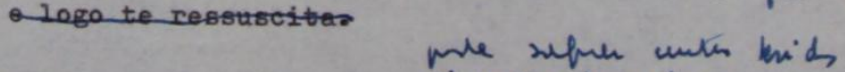
i caps is sifer knias

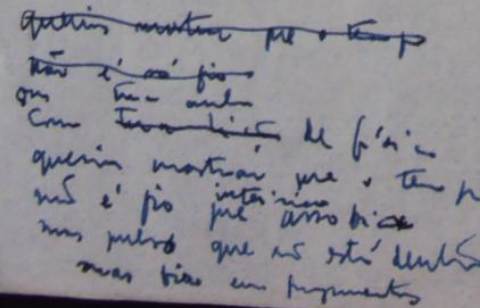

26

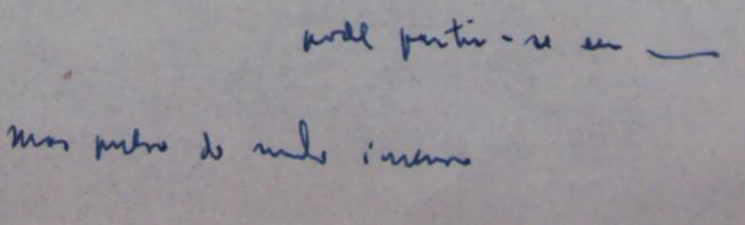

Datiloscrito reformulado da sétima parte do poema. Pasta Pi. Poemas pernambucanos, fólio 26 recto. Arquivo literário de João Cabral de Melo Neto, Fundação Casa de Rui Barbosa. 


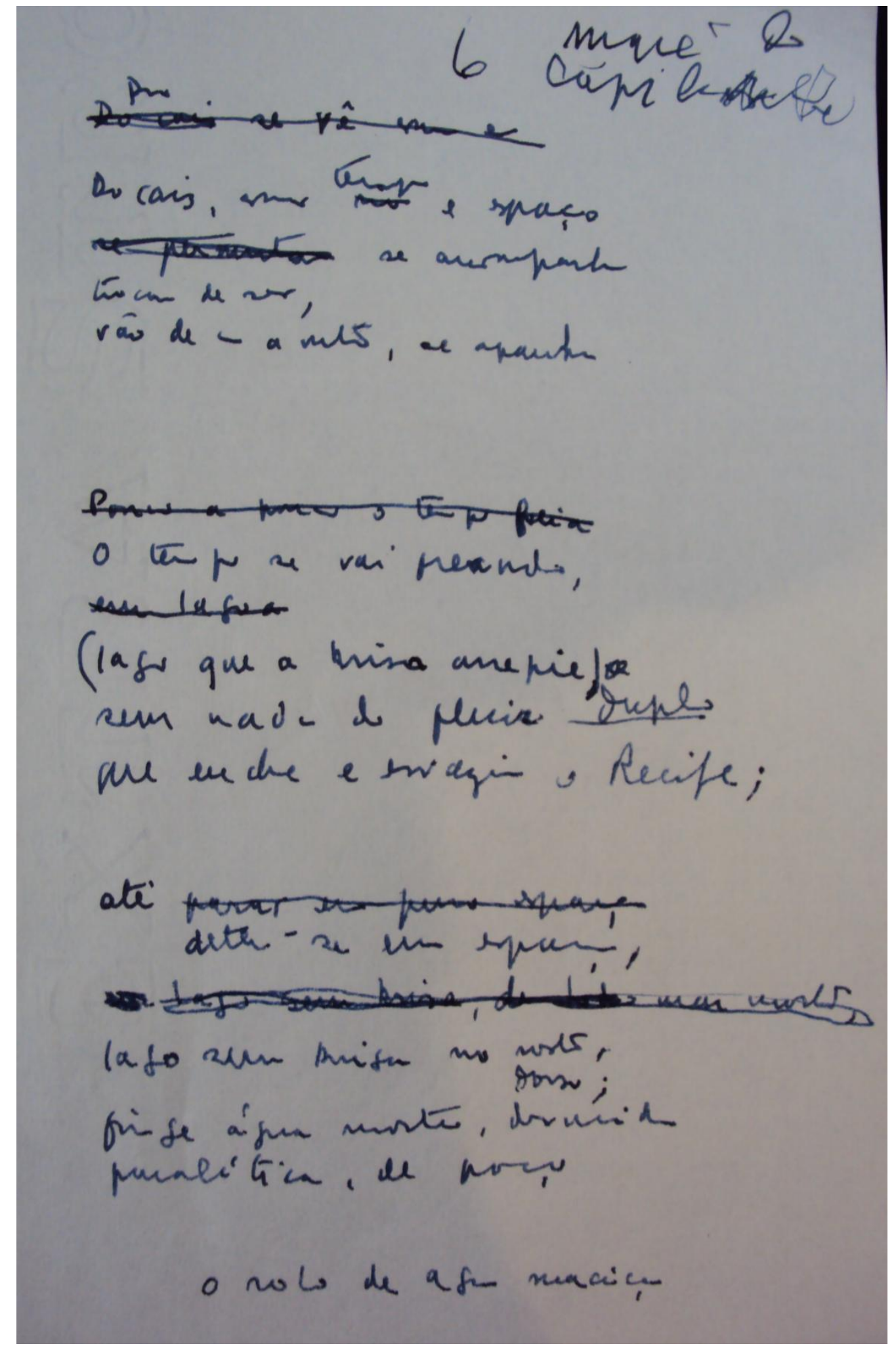

Manuscrito da sexta parte do poema. Pasta Pi. Poemas pernambucanos, folha solta sem indicação de fólio. Arquivo literário de João Cabral de Melo Neto, Fundação Casa de Rui Barbosa. 


\section{Anexo 11: "Descoberta da literatura"}

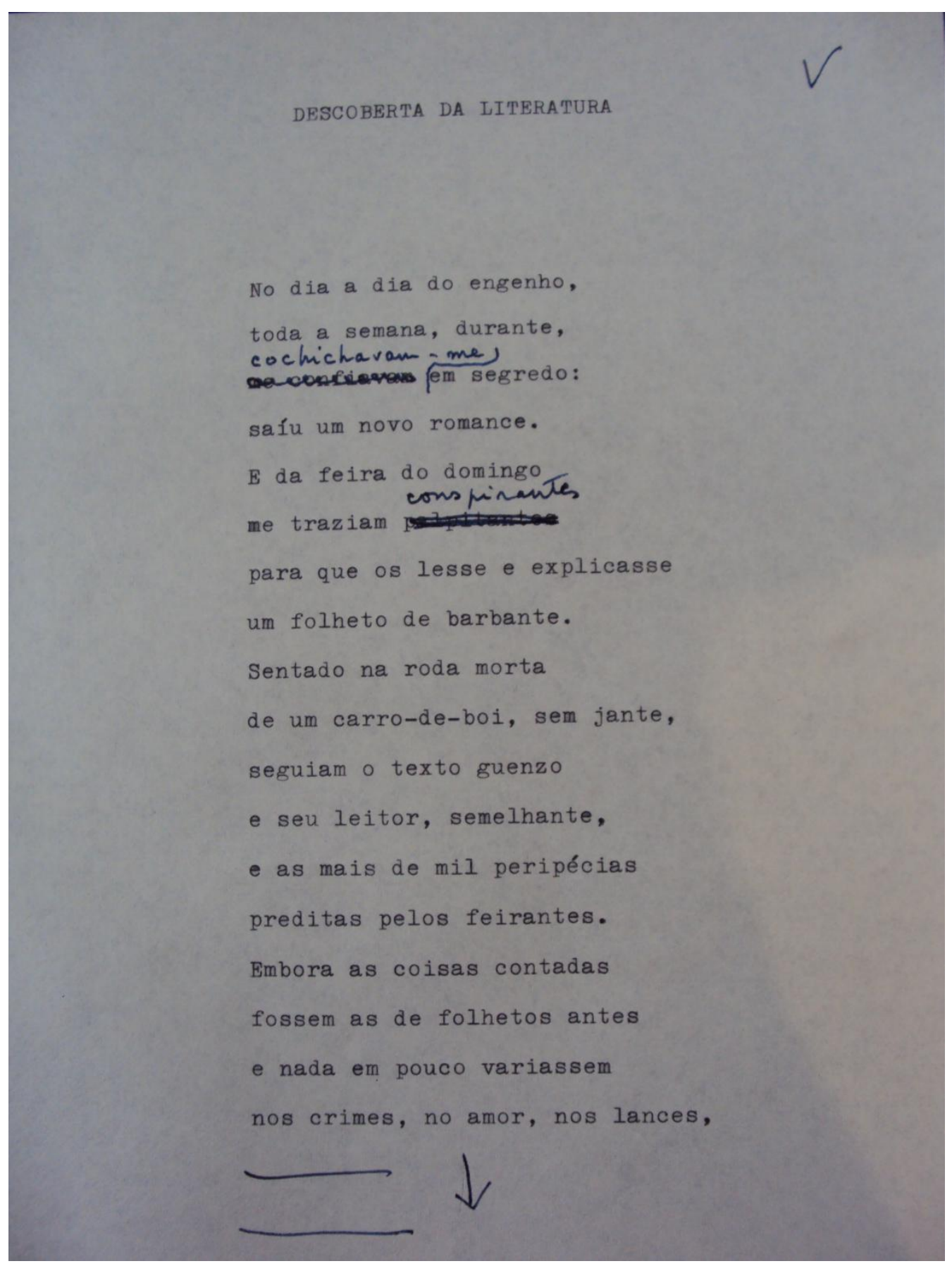

Datiloscrito reformulado do poema. Pasta Pi. Poemas pernambucanos. Original, sem indicação de fólio. Arquivo literário de João Cabral de Melo Neto, Fundação Casa de Rui Barbosa. 


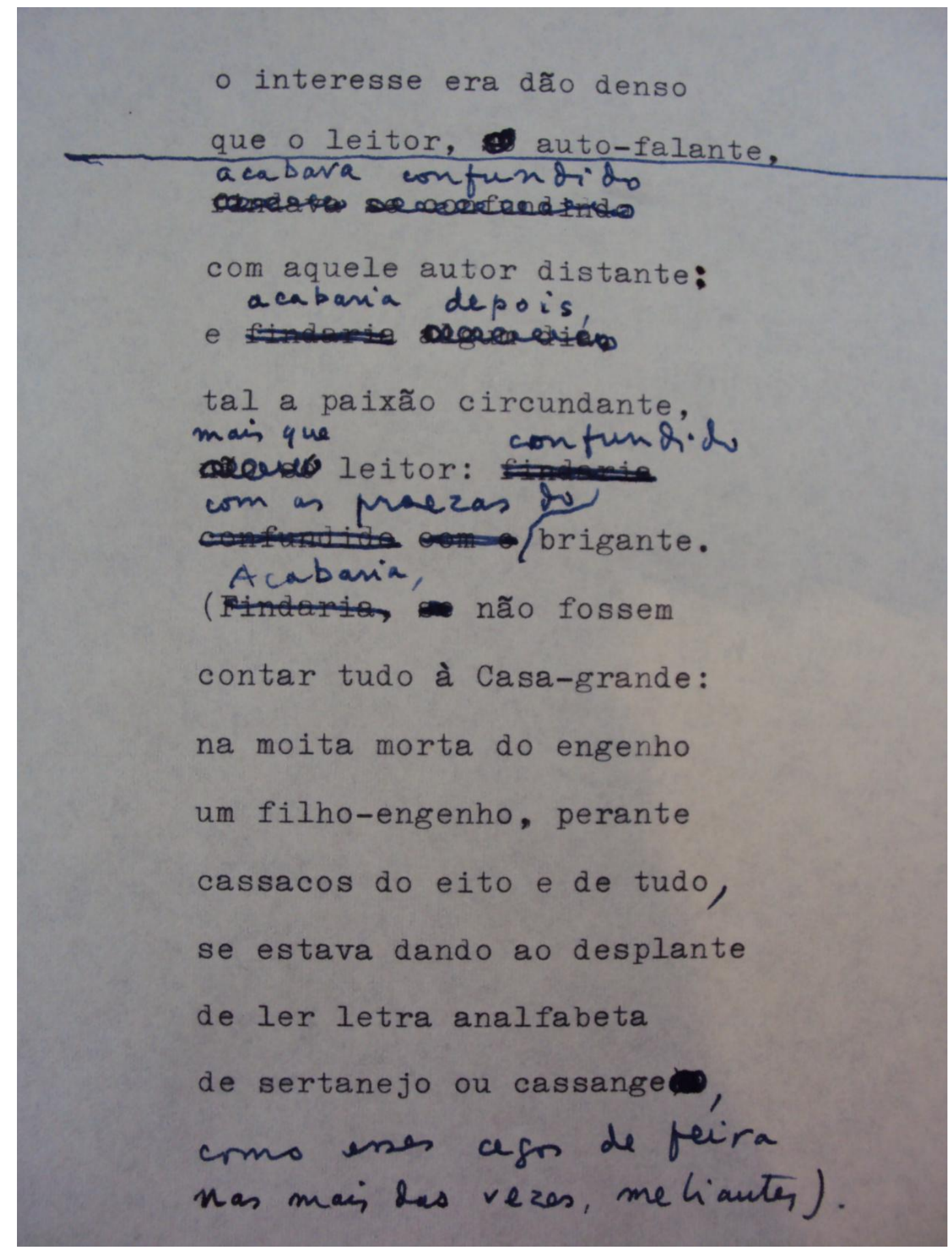

Datiloscrito reformulado do poema. Pasta Pi. Poemas pernambucanos. Original, sem indicação de fólio. Arquivo literário de João Cabral de Melo Neto, Fundação Casa de Rui Barbosa. 


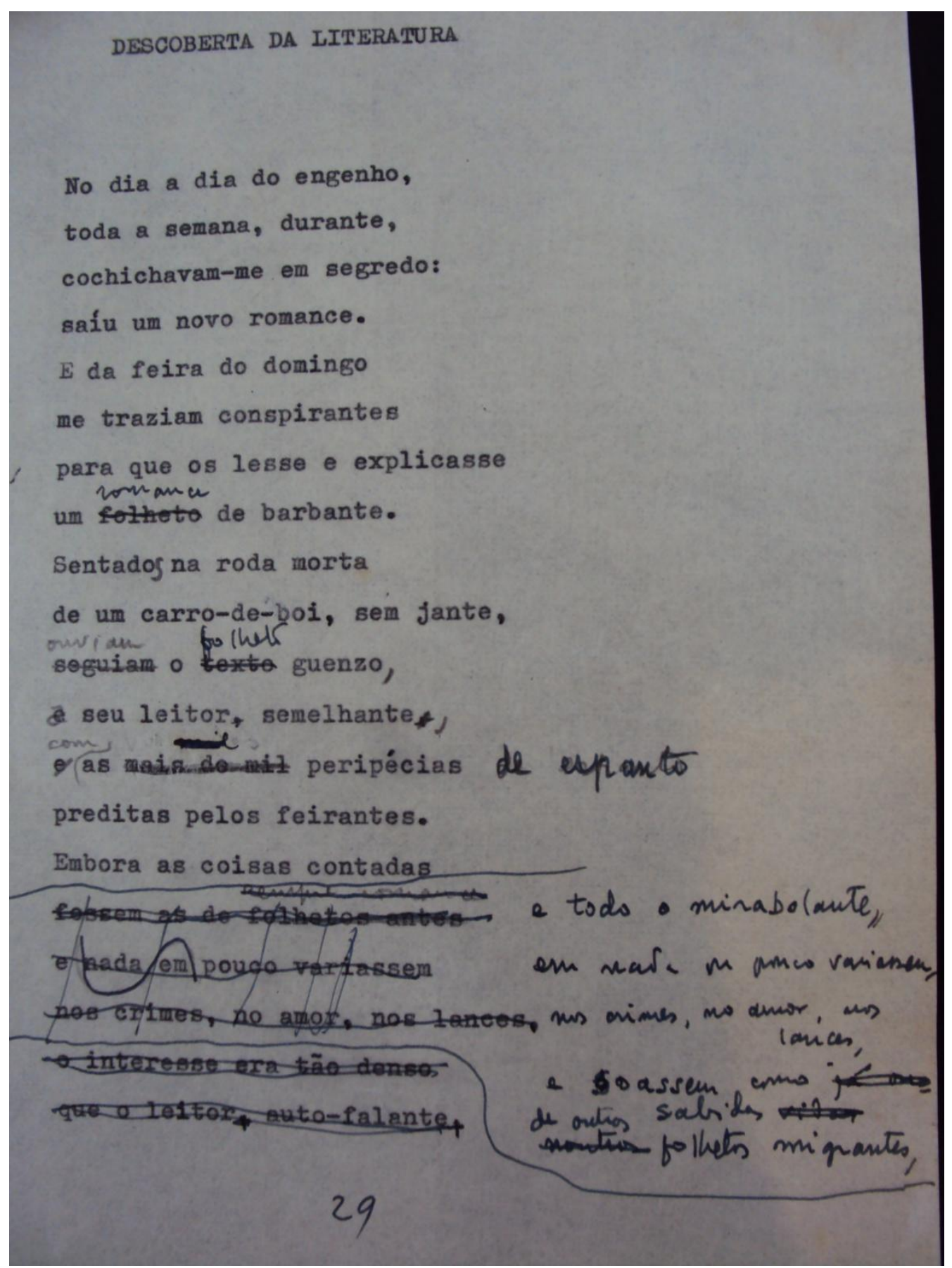

Datiloscrito reformulado do poema. Pasta Pi. Poemas Pernambucanos.

Original, fólio 29 recto. Arquivo literário de João Cabral de Melo Neto, Fundação Casa de Rui Barbosa. 


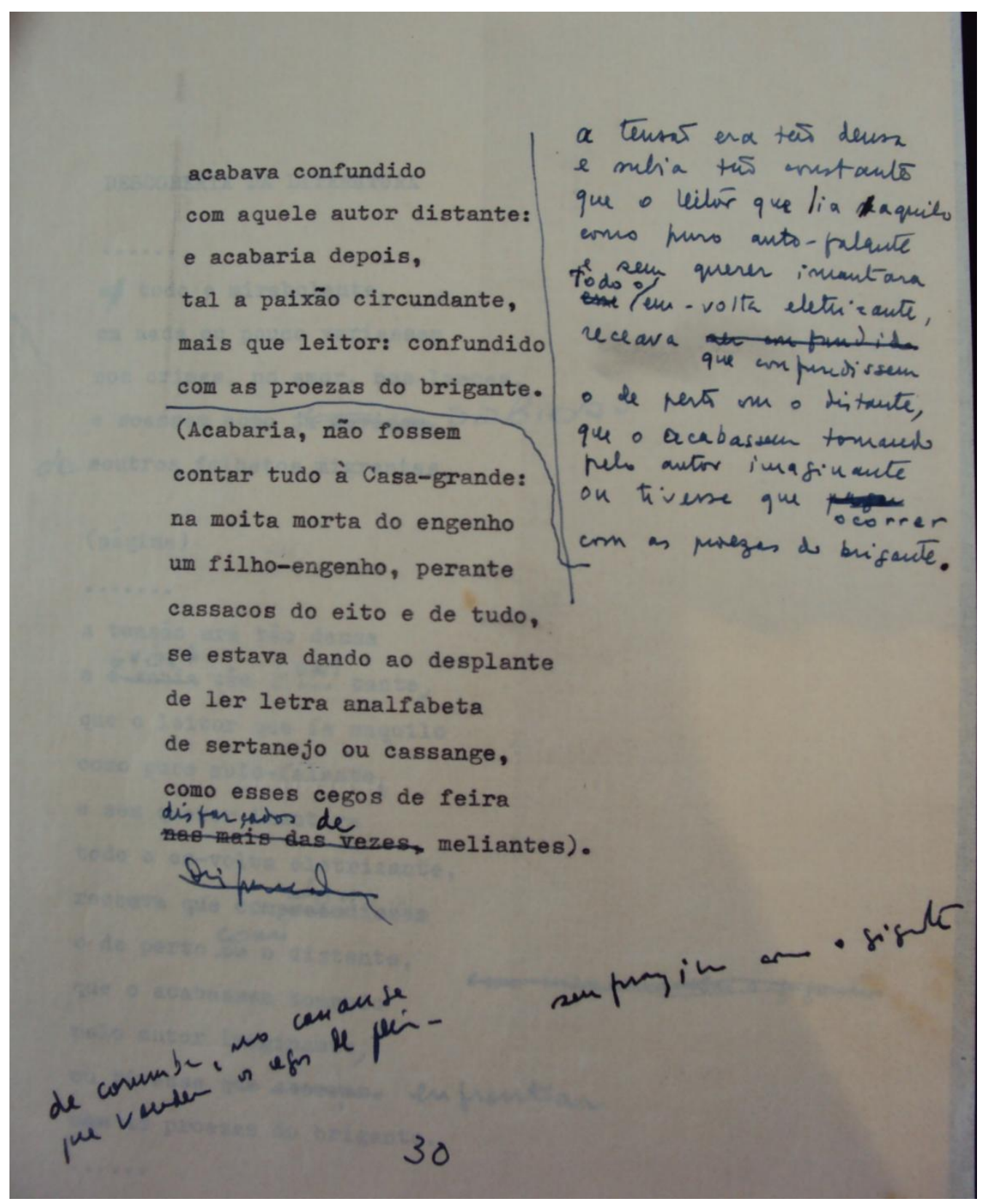

Datiloscrito reformulado do poema. Pasta Pi. Poemas pernambucanos. Original, fólio 30. Arquivo literário de João Cabral de Melo Neto, Fundação Casa de Rui Barbosa. 
Transcrições 


\section{“Prosas da maré na Jaqueira", primeira versão}

Pasta Pi. Poemas pernambucanos. Original. Sem indicação de fólio.

A maré

1.

Maré do Capibaribe,

em frente de quem nasci,

a cem metros do combate

da foz do Parnamirim.

Na história, lia de um rio

vivo em tudo o que o Recife,

o rio

sem saber que aquele em frente

era o tal Capibaribe.

Como o mar chega à Jaqueira,

e chega mais longe, até,

como toda a gente em casa

te chamava de <"a> maré". 
Maré do Capibaribe,

onde é mangue teu estilo:

já não saltas entre agrestes,

andas plano e comedido.

Não é<s> mais o fio frágil

que a seca corta e evapora:

na Jáqueira já és maré,

és ancho e a quase toda hora.

O teu rio linear de antes

viaja duplo, faz refaz:

ora te leva onde o mar, ora de volta de traz. 
3.

Maré do Capibaribe,

minha leitura e cinema:

quando não só discorrias

tua água sem nada, apenas,

muita coisa me mostraste,

maré baixa ou maré cheia:

mais coisas do que as imagens

que livro ou filme nos deixa.

Quando

Ese não trazias nada.

teu celulóide sem filme

o corpo

projetava esse fluir grosso

tempo

do corpo Capibaribe. 
4.

Maré do Capibaribe,

afinal que inoculaste

no ex-menino que ainda hoje

vive como te levasse?

Não sei se foi para sim

ou para não teu colégio:

água

os discursos de tua earne água

sem estrelas, rio cego,

de tua água sem azuis,

água de rio indigente

e o

teu pisar elefantíaco

que ao vir do Recife aprendes. 
5.

Maré do Capibaribe,

mestre monocórdio e

professor de todo mudo,

que ensinaste ao anti-poeta

além

mais de à música ser mudo?

Nada de métrica larga

claudelina, de teu ritmo,

não lhe ensinaste a escrever

o verso Cardozo e liso,

teu sensual falar Gilberto,

teu feérico de Cícero:

Recife

talvez às línguas jaqueiras

não me julgaste propício. 
Maré do Capibaribe

na Jaqueira, onde menino,

cresci vendo-te passar

com passo espesso e bovino.

Rio com quem convivi

convívio,

sem saber que tal convívio,

uma droga

quase maconha me dava

o mais vazio dos vícios:

dos quandos em frente ao cais

em teu passar

via-te deslisar lento

um vício, ouvir

veio-me outro, o de escutar

e sentir passar-me o tempo. 
Maré do Capibaribe

entre a Jaqueira e Santana

há momentos que a maré,

seu ir e vir, te empatana.

Então teu tempo é espaço, água

tua eөbra-de passar grosso

é uma água morta, dormida,

paralítica, de poço.

Teu tempo é somente espaço,

és lagoa que se finge

sem nada do fluir duplo

que enche e esvazia o Recife. 
8.

Maré do Capibaribe,

estaria a lição nisso,

em se mostrar como espaço

nos quandos em equilíbrio?

(Quandos em que tempo e espaço,

em que às vezes te deténs,

se confundem nesse enquanto

em que tu não vás nem vens).

Querias deter o tempo

no lago morto que imitas?

Ele só vai, sem marés,

e logo te ressucita. 
9.

Maré do Capibaribe,

tua lição é essa pugna a luta trunca ouvi tua mensagem dupla:

na crista

mesmo <se> imóvel, no equilíbrio

da maré, lembres laguna,

mesmo se tua água espessa,

quase músculo, ou de cobra,

esteja finja

passe em coisa, esteja espaço,

és só tempo, muito embora:

és expressão desse vento,

mais sutil que qualquer brisa,

mas de

que nos sopra, no mais dentro,

[ileg.] [ileg.]

$<$ na $>$ na direção que descria des-cria

[ileg.] 
10.

Maré do Capibaribe, aprendi

$<\mathrm{e}>$ euvi tua outra lição:

mbora tu desças, subas,

tenhas mão e contra-mão,

muito mais desce $\$$ que sobe $\$$

da água pouca que te chega,

Capibaribe, e sem mar no ponto em que o mar, sé rio,

no onde em que a maré te deixa.

Capibaribe, te deixes.

Ese Teu rio

Assim, nunca vem de novo,

seu passar é uma só vez.

na maré cheia ou vazia,

O tempo se lê, se vive,

da água tempo que passou

cada

nas várias vezes por dia.

mas não se deixa reler. 


\title{
"Prosas da maré na Jaqueira", segunda versão
}

Pasta Pi. Poemas Pernambucanos. Fólio 19

\author{
Canções da maré \\ A maré \\ na Jaqueira
}

1.

\begin{abstract}
Maré do Capibaribe,
em frente de quem nasci,

a cem metros do combate

do foz do Parnamirim.
\end{abstract}

Na história, lia de um rio

onde muito em Pernambuco

vivoem tudo oque o Recife, estudo

sem saber que o rio em frente público

era o [ileg.] quase tudo tudo

era 0 tal Capibaribe.

próprio

Como o mar chega à Jaqueira,

e chega mais longe, até,

no dialeto da família

como toda a gente em casa

te chamava de "a maré". 
Fólio 20.

2.

Maré do Capibaribe,

já de

ende é mangue <é> teu estilo:

já não saltas entre agrestes,

andas plano e comedido.

Não és mais o fio frágil

que a seca corta e evapora:

na Jaqueira já és maré,

ancho de água qualquer

és anchø e a quase toda hora.

cadeiruda

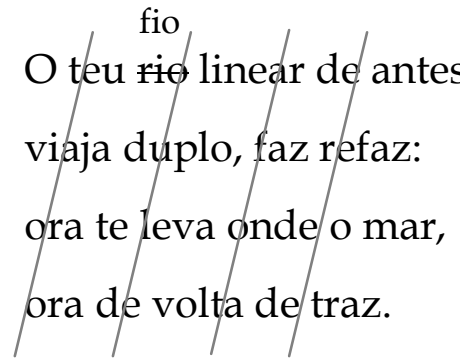

Teu rio franzino de antes

a areia não bebe mais:

é a maré que o bebe agora

(não é muito o que lhe dás). 


\section{Fólio 21}

3.

Maré do Capibaribe,

minha leitura e cinema:

quando não sé discorrias não dura vazia muito

tua água sem nada, <água> apenas, fuilme teu filme

$<\mathrm{M}>$ muita coisa me mostraste, discorrias $<\mathrm{s}>$

maré baixa ou maré cheia: <,> coisas de nada ou pobreza

mais coisas do que as imagens

que livro ou filme nos deixa.

$\begin{array}{cc}\text { <E }>\text { Quando não trazias nada, } & \\ \text { teu celulóide sem filme } & \text { o espetáculo era circo } \\ \text { projetava o corpo grosso } & \text { onde ver as várias formas } \\ \text { do tempo Capibaribe. } & \text { de ser tempo a maré-rio. }\end{array}$

pela água que mais imagens

que-filme livro ou filme carregas

2/

mais coisas do que imagens que filme ou livro deixava que em sessões contínuas mais que filme ou livro mais que as dos filmes de então enho [ileg.] [ileg.] tuas imagens dos rios mais que $<$ as $><$ nos $>$ filmes, depois, mais que [ileg.] todas as viagens 
Fólio 22.

em cujo bolso

a

em quem pesas

ao [ileg.] aluno que te leva

no bolso como uma chave

pesas ainda com chave?

tu pesas como uma chave

Maré do Capibaribe,

ensinaste

afinal $<$ o $>$ que inoculaste

o que ensinaste

no ex-menino que ainda hoje

em cujo

vive como te levasse?

ao aluno que ne bolso

tu pesas como uma

chave?

Não sei se foi para sim

ou para não teu colégio:

o discurso de tua água

sem estrelas, rio cego,

de tua água sem azuis,

água de rio indigente,

e o pisar de elefantíase

que ao vir ao Recife aprendes. 
Fólio 23.

\begin{tabular}{c|l}
$5 .<4>$ & $\begin{array}{l}\text { M. [ileg.] } \\
\text { clima } \\
\text { língua } \\
\text { prima } \\
\text { Certo às escritas Recife } \\
\text { línguas de Recife } \\
\text { te parecera então [ileg.] }\end{array}$ \\
\hline
\end{tabular}

mestre monocórido e mudo,

que ensinaste ao anti-poeta

além

$<(>$ mais de à música ser mudo? $<)>$

Nada de métrica larga

claudelina, de teu ritmo,

não lhe ensinaste a escreve

o segredo
a escreve

$<\mathrm{d}>\mathrm{o}$ verso Cardozo e liso,

a frase teia de Pena

teu sensual falar Gilberto,

teu engenho de Vicente

teu feérico de Cícero: $<$ ? >

a rede leve

$<\mathrm{T}>$ Łalvez às línguas Recife

tua leveza de Pena?

não me julgaste propício.

os inventos de Vicente

Para poeta do Recife
me era preciso outra

língua

a lei

o véu

o viez de Matheos de Lima

viez

a frase <leve $>$ - em teia de Pena

Para poeta de Recife

achaste faltar-me a língua

clima 
Fólio 24.

6. $<8>$

Maré do Capibaribe

na Jaqueira, onde menino,

cresci vendo-te passar

com passo espesso e bovino.

Rio com quem convivi

sem saber que tal convívio,

quase uma droga me dava

o mais vazio dos vícios:

dos quandos em frente ao cais

via-te em teu passar lento

ver

veio-me um vício, o de ouvir

e sentir passar-me o tempo. 
Fólio 25.

7.

Maré do Capibaribe

entre a Jaqueira e Santana

há momentos que a maré,

seu ir e vir, te empatana.

Então teu tempo <parece> é espaço,

<em>tua água de passar grosso de [ileg.] de lodo

adormecida

é uma água morta, dormida,

[ileg.]

paralítica, de poço.

E foi no mesmo breve instante

Teu tempo é somente espaço,

que a lagoa não

és lagoa que se finge

não se sente $o$

sem nada do fluir duplo

que enche e esvazia o Recife. 
Fólio 26.

8. $<7>$

Maré do Capibaribe,

estaria a lição nisso,

em se mostrar como espaço

nos quandos em equilíbrio?

Em se mostrar como espaço

espaço tem

ou mostrar que o tempe

o tempo dentro de si

com [ileg.]

que ambos são dois e ninguém [ileg.]

fragmento

segmento
(Quandos em que tempo e espaço,

em que às vezes te deténs,

se confundem nesse enquanto

em que tu não vás nem vens).

Querias deter o tempo

no lago morto que imitas?

Ele sé vai, sem marés, ou mostrar que o tempo um fio

e logo te ressucita.

pode sequer conter brisas

é capaz de sofrer brisas

queiras mestrar que otempo

nãoésófio

[ileg] tuas aulas

com tua lição de física

pode partir-se em [ileg.]

querias mostrar que o tempo

inteiriço

não é fio que assobia

mas pulso que não está dentro

mas fia em fragmentos

mas pulso de minha [ileg.] 


\title{
Fólio não numerado
}

\author{
Maré do \\ 6 Capibaribe \\ [ileg.] \\ Do caissevêcomoés \\ tempo \\ Do cais, como no e espaço \\ se permutam se acompanham \\ trocam de ser \\ vão-se um a outro, se apanham \\ Parece a [ileg.] o tempo freia \\ O tempo se vai freando \\ em lagoa \\ (lago que a brisa arrepia) \\ sem nada do fluir duplo \\ que enche e esvazia o Recife; \\ até parar em puro espaço \\ deter-se em espaço, \\ [ileg.] lago sem brisa, de [ileg.] mar morto \\ lago sem brisa no rosto, \\ dorso; \\ finge água morta, dormida \\ paralítica, de poço
}

o rolo de água maciça 


\section{ÍNDICE}


CAṔ́tULO 1. A POIÉTICA COMO CIÊNCIA E FILOSOFIA DAS CONDUTAS CRIATIVAS 25

1. 1. PAUL VALÉRY E A FUNDAÇÃo DA POIÉTICA 25

1. 2. RenÉ PASSERON E O deSENVOLVIMENTO de UMA POIÉTICA GERAL 36

1. 3. PaRAdigma Poiético Versus Paradigma eidÉtICO 49

CAPítULO 2. A CRíTICA GENÉtICA COMO ESTUDO DA GÊNESE DA OBRA DE ARTE LITERÁRIA ATRAVÉS DOS MANUSCRITOS

2. 1. O MANUSCRITO LITERÁRIO COMO OBJETO DA CRÍTICA GENÉTICA

2. 2. OPERAÇÕES DE PRODUÇÃO TEXTUAL E MÉTODOS DE TRANSCRIÇÃO DOS MANUSCRITOS 58

2. 3. MÉTOdO LINGUíSTICO DE INTERPRETAÇÃO DO MANUSCRITO: O FENÔMENO DA PARÁFRASE 64

2. 4. DuAS CONCEPÇÕES DE PRÁfrase: BeRnARd PottIER E CATHERINE FuCHS 68

2. 5. PARÁFRASE: EQUIVALÊNCIA E ASSIMETRIA 83

2. 6. ANÁLISE GENÉTICA DA PARÁFRASE

CAPítUlo 3. PoiÉtICA E CRÍtICA GeNÉtICA 96

3. 1. DUAS CRÍTICAS DA POIÉTICA À GENÉTICA TEXTUAL 96

3. 2. Programação e processo, projeto e trajeto 98

3. 3. O ATO CRIATIVO E SEU TRAÇO 105

PARTE 2. REPRESENTAÇÃO DA CRIAÇÃO NA OBRA DE JOÃO

CABRAL DE MELO NETO 109

CAPítUlo 1. PreVISIBILIDAdE E ESTABILIDADE do FAZER: A METÁFORA do POETA-ARQUITETO E dA MINERALIZAÇÃO DA PALAVRA 113

1. 1. O POETA-ARQUITETO 113

1. 2. A MINERALIZAÇÃO DA PALAVRA 127

CAPÍTULO 2. IMPREVISIBILIDADE E INSTABILIDADE DO FAZER LITERÁRIO EM O ENGENHEIRO, “FÁBULA dE ANFION” E “PSICOLOGIA DA COMPOSIÇÃO” 134

2. 1. A REPRESENTAÇÃO DO FAZER EM O ENGENHEIRO 134

2. 2. Projeto e realização arquitetônicos em “Fábula de ANFion”

2. 3. SUJEITO CRIAdOR E ObRA EM PROCESSO NO POEMA “PSICOLOGIA DA COMPOSIÇÃO” 165

CAPÍTULO 3. A REESCRITA CONTÍNUA 178

3. 1. O "GOSTO PELO FAZER" 178

3. 2. A AUSÊNCIA DE REGRAS COMPOSITIVAS E O INACABAMENTO DA OBRA 188

3. 3. "UM POEMA É O QUE HÁ DE MAIS INSTÁVEL" 198

PARTE 3. PRÁTICA DA CRIAÇÃO: OS MANUSCRITOS DE JOÃO

CABRAL DE MELO NETO 213 
1. 1. DESCRIÇÃO DO DOSSIÊ 218

1. 2. DIVISÃO E SERIAÇÃO: A MUDANÇA DE TítULO 222

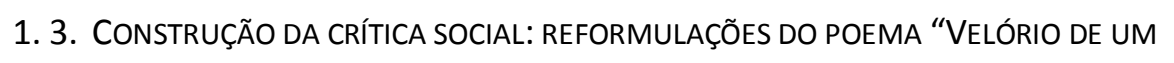
COMENDADOR" 226

1. 4. DO METAFí́IICO AO SENSUAL: REFORMULAÇÕES DO POEMA “ESCRITOS COM O CORPO" 232

1. 5. Do estétICO AO POLÍtICO: O MANUSCRITO do POEMA “GRACILIANO RAMOS:" 239

CAPÍTULO 2. O DOSSIÊ DE A EDUCAÇÃO PELA PEDRA 252

2. 1. OS DOCUMENTOS GENÉTICOS

2. 2. A "PLANTA BAIXA" E A COMPOSIÇÃO DOS POEMAS 255

2. 3. REFORMULAÇÕES LOCAIS 269

2. 4. ASNOTAS METALINGUÍSTICAS 280

2. 5. O MANUSCRITO dO POEMA “CATAR FEIJÃO” 293

CAPÍtULO 3. O DOSSIÊ DE A ESCOLA DAS FACAS

3. 1. A OPERAÇÃO DO POEMA INSTÁVEL 308

3. 2. "Cortes" e "transplantes" no manuscrito de "Prosas da maré na Jaqueira" 316

3. 3. UM CASO DE "ENXERTO": O MANUSCRITO dO POEMA “DESCOBERTA DA LITERATURA" 332

CONCLUSÃO 337

$\begin{array}{ll}\text { BIBLIOGRAFIA } & 342\end{array}$

JoÃo Cabral de Melo Neto 343

OBRAS 343

DOCUMENTOS MANUSCRITOS

CORRESPONDÊNCIA/BIBLIOGRAFIA $\quad 344$

DISCOGRAFIA $\quad 345$

ENTREVISTAS $\quad 345$

SOBRE O AUTOR $\quad 346$

TESES E DISSERTAÇÕES

$\begin{array}{ll}\text { LIVROS E ARTIGOS } & 347\end{array}$

BIBLIOGRAFIA TEÓRICA $\quad 350$

$\begin{array}{ll}\text { ANEXOS } & 360\end{array}$

CÓPIAS FOTOGRÁFICAS $\quad 361$

ANEXO 1: "VeLóRIO DE UM COMENDADOR" 362

ANEXO 2: "ESCRITOS COM O CORPO" 364

anexo 3: "Gracillano Ramos:" 366

ANeXo 4. "CATAR FeiJão" 370

ANEXO 5: "BiFURCADOS DE 'HABITAR O TEMPO”” 
ANEXO 6: "HABITAR O TEMPO"

ANEXO 7: "NA MORTE DOS RIOS"

376

ANEXO 8: "PARA A FEIRA DO LIVRO"

ANEXo 9: "PlantA BAIXA" DE A EDUCAÇÃo PELA PEDRA

ANeXo 10: "Prosas da maré na JaQueira"

382

ANEXO 11: "DESCOBERTA DA LITERATURA"

391

TRANSCRIÇÕES

395

“PROSAS DA MARÉ NA JAQUEIRA", PRIMEIRA VERSÃO

396

"Prosas da MARÉ Na JAQUeIRA", SEgunda Versão

406

ÍNDICE 